ORNL/TM-13558

\title{
ORNL ENGINEERING DESIGN AND CONSTRUCTION REENGINEERING REPORT
}

\section{RECEIVED \\ MAR 031998 \\ QSTI}

MANAGED AND OPERATED BY

LOCKHEED WARTIN ENERGY RESEARCH CORPORATION FOA THE UNTED STATES

DEPARTIIENT OF ENERGY
MASTER

Ja

DISTRIBUTION OF THIS DOCUMENT IS UNLMMTED 
This report has been reproduced directly from the best available copy.

Available to DOE and DOE contractors from the Office of Scientific and Technical Information, P.O. Box 62, Oak Ridge, TN 37831; prices available from (615) 576-8401, FTS 626-8401.

Available to the public from the National Technical Intormation Service, U.S. Department of Commerce, 5285 Port Royal Rd., Springfield, VA 22161.

This report was prepared as an account of work sponsored by an agency of the United States Government. Neither the United States Government nor any agency thereof, nor any of their empioyees, makes any warranty, express or implied, or assumes any legal liability or responsibility for the accuracy, completeness, or usefulness of any information, apparatus, product, or process disclosed, or represents that its use would not infringe privately owned rights. Reference herein to any specific commercial product, process, or service by trade name, trademark, manufacturer, or otherwise, does not necessarily constitute or imply its endorsement, recommendation, or favoring by the United States Government or any agency thereof. The views and opinions of authors expressed herein do not necessarily state or reflect those of the United States Government or any agency thereof. 


\section{DISCLAIMER}

Portions of this document may be illegible electronic image products. Images are produced from the best available original document. 
ORNL/TM-13558

\title{
ORNL ENGINEERING DESIGN AND CONSTRUCTION REENGINEERING REPORT
}

\section{E. McNeese, Team Leader}

ORNL Engineering Design and Construction Reengineering Team
S. E. Burnette
E. H. Krieg
J. T. Etheridge
J. W. Mathys
E. C. Fox
A. R. Medley
S. D. Frey
T. E. Myrick
J. N. Herndon
B. D. Patton
R. C. Juras
J. A. Setaro
L. C. Kelly

Date Published: January 1998

\author{
Prepared by \\ Oak Ridge National Laboratory \\ Oak Ridge, Tennessee 37831-6285 \\ managed by \\ Lockheed Martin Energy Research Corp. \\ for the \\ U.S. Department of Energy \\ under Contract No. DE-AC05-96OR22464
}




\section{CONTENTS}

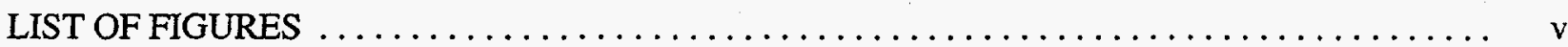

LIST OF TABLES $\ldots \ldots \ldots \ldots \ldots \ldots \ldots \ldots \ldots \ldots \ldots \ldots \ldots \ldots \ldots \ldots \ldots \ldots \ldots$

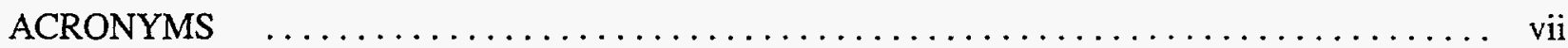

EXECUTIVE SUMMARY $\ldots \ldots \ldots \ldots \ldots \ldots \ldots \ldots \ldots \ldots \ldots \ldots \ldots \ldots \ldots \ldots \ldots \ldots \ldots$

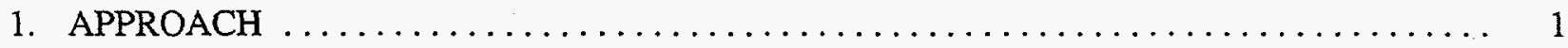

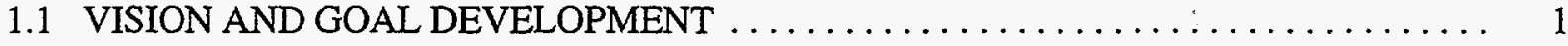

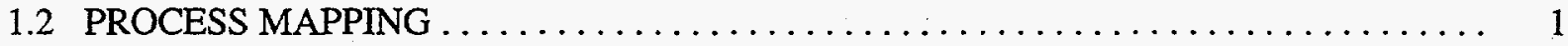

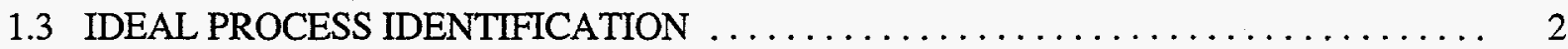

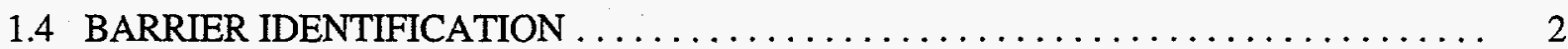

1.5 BENCHMARKING AND SURVEYS $\ldots \ldots \ldots \ldots \ldots \ldots \ldots \ldots \ldots \ldots \ldots \ldots \ldots \ldots \ldots \ldots \ldots \ldots$

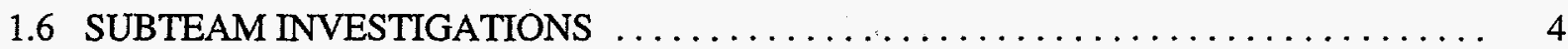

1.7 DEVELOPMENT OF TEAM RECOMMENDATIONS $\ldots \ldots \ldots \ldots \ldots \ldots \ldots \ldots \ldots \ldots$

1.8 PROPOSAL FOR NEW ED\&C PROCESS AND ITS IMPLEMENTATION $\ldots \ldots \ldots \ldots 5$

2. DESCRIPTION OF CURRENT SITUATION $\ldots \ldots \ldots \ldots \ldots \ldots \ldots \ldots \ldots \ldots \ldots \ldots \ldots \ldots$

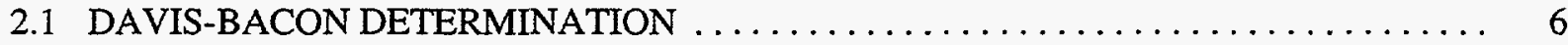

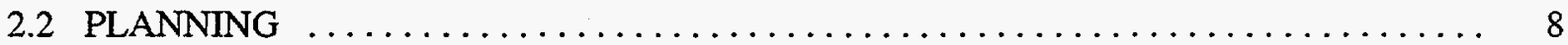

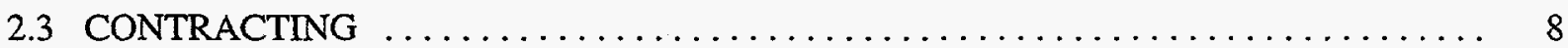

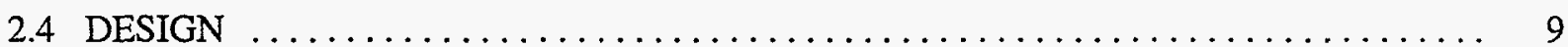

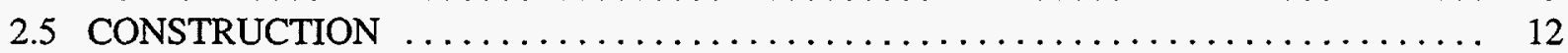

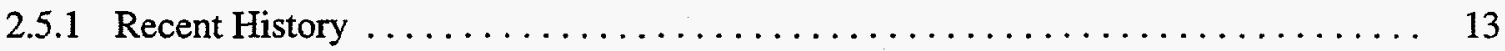

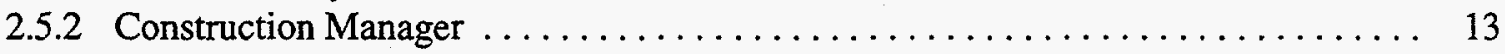

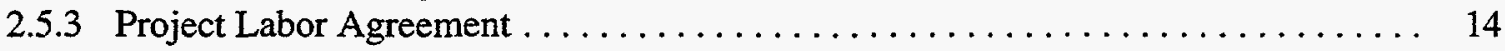

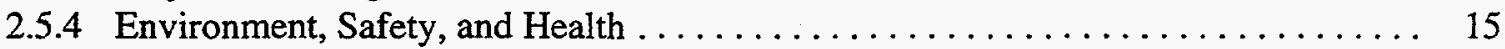

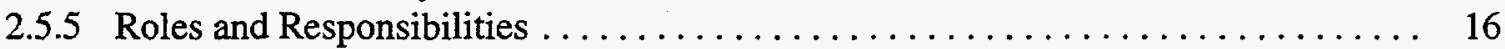

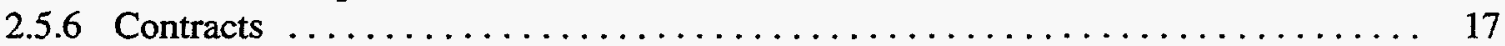

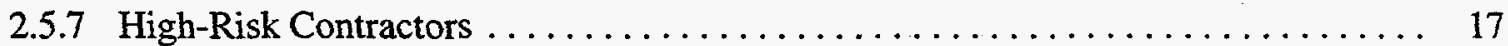

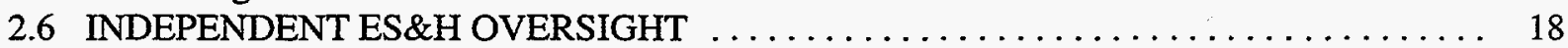

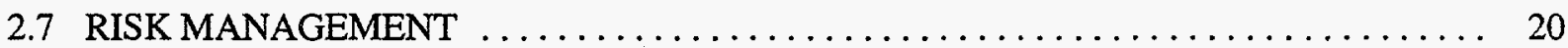

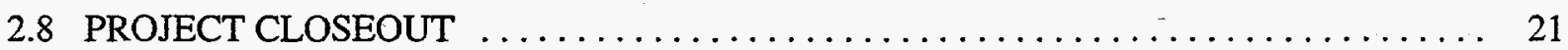

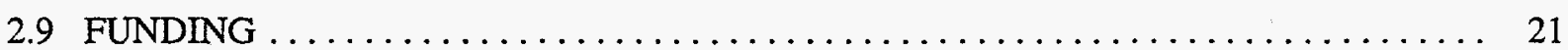

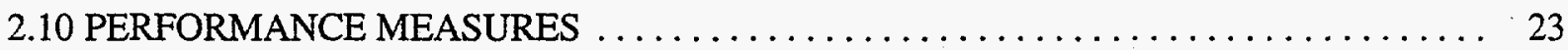

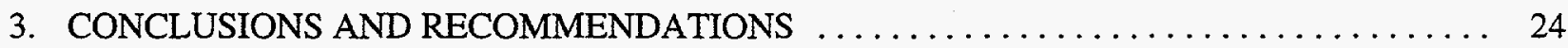

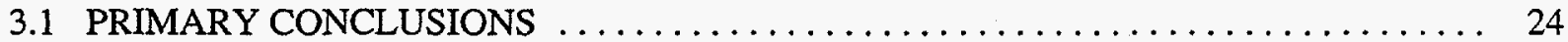

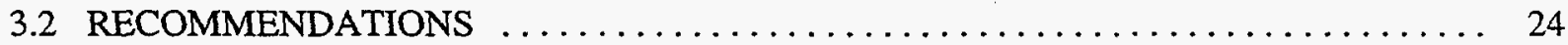

3.2.1 Recommendation 1: Construction Manager .................... 25

3.2.2 Recommendation 2: Project Labor Agreement (PLA) $\ldots \ldots \ldots \ldots \ldots \ldots \ldots \ldots . \ldots . \ldots . \ldots$

3.2.3 Recommendation 3: Roles and Responsibilities .................. 26

3.2.4 Recommendation 4: Flexibility and Innovation in Contracting $\ldots \ldots \ldots \ldots \ldots . \ldots \ldots$

3.2.5 Recommendation 5: Contractor Qualifications ................... 27

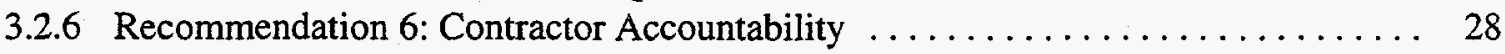

3.2.7 Recommendation 7: ES\&H Oversight ...................... 28

3.2.8 Recommendation 8: Davis-Bacon Act Compliance .................... 29 
3.2.9 Recommendation 9: Performance Measures .................... 29

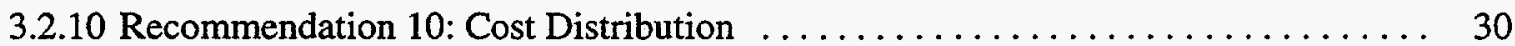

3.2.11 Recommendation 11: Infrastructure Configuration Management .......... 30

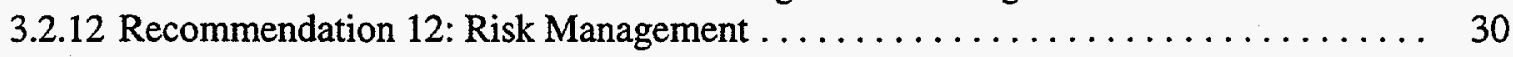

3.2.13 Recommendation 13: Funding Delays and Limitations $\ldots \ldots \ldots \ldots \ldots \ldots \ldots \ldots$

3.2.14 Recommendation 14: Infrastructure Support Planning . . . . . . . . . . 32

3.3 GUIDING PRINCIPLES FOR IMPLEMENTING RECOMMENDATIONS . . . . . . . 32

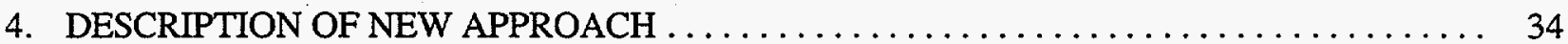

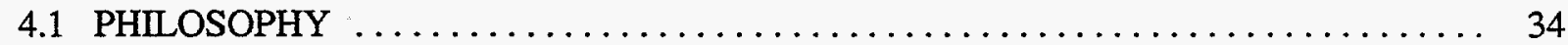

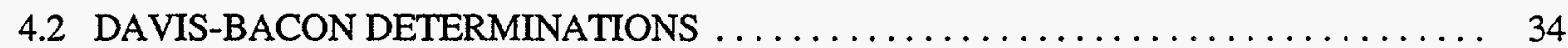

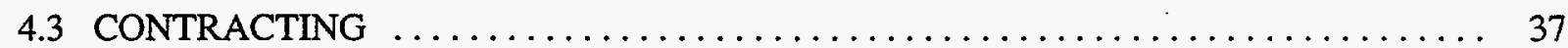

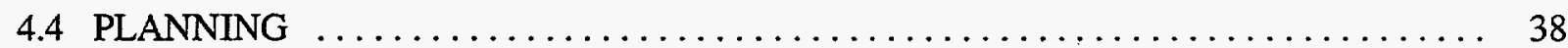

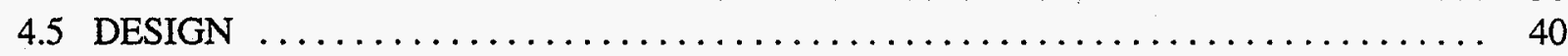

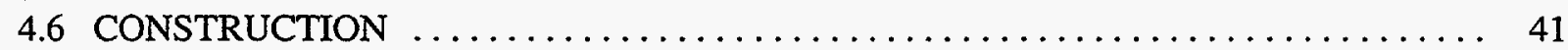

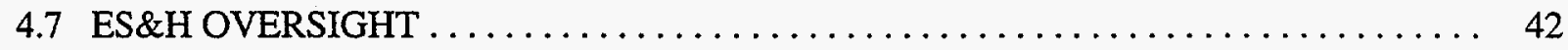

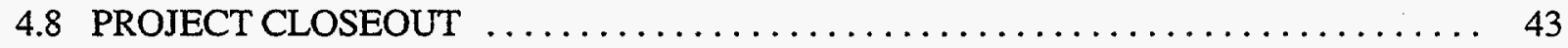

5. COST SAVINGS WITH NEW APPROACH FOR SELECTED PROJECTS $\ldots \ldots \ldots \ldots \ldots$

6. PLAN FOR IMPLEMENTATION OF NEW ED\&C APPROACH $\ldots \ldots \ldots \ldots \ldots \ldots \ldots \ldots \ldots$

6.1 ED\&C REENGINEERING IMPLEMENTATION PLAN $\ldots \ldots \ldots \ldots \ldots \ldots \ldots \ldots \ldots \ldots$

6.2 NECESSARY AND SUFFICIENT STANDARDS FOR ENGINEERING DESIGN . . . . . 49

6.3 NECESSARY AND SUFFICIENT STANDARDS FOR CONSTRUCTION AND

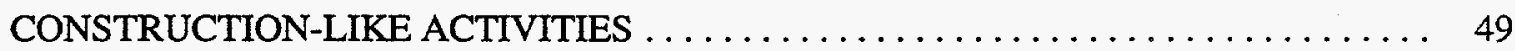

6.4 ED\&C GUIDELINES, POLICIES, AND PROCEDURES $\ldots \ldots \ldots \ldots \ldots \ldots \ldots \ldots \ldots \ldots$

6.5 CONSTRUCTION CONTRACTING FOR ORNL $\ldots \ldots \ldots \ldots \ldots \ldots \ldots \ldots \ldots \ldots \ldots$

6.6 LONG-RANGE ACQUISITION STRATEGY FOR ED\&C SERVICES $\ldots \ldots \ldots \ldots \ldots$

ACKNOWLEDGMENTS $\ldots \ldots \ldots \ldots \ldots \ldots \ldots \ldots \ldots \ldots \ldots \ldots \ldots \ldots \ldots \ldots \ldots \ldots \ldots$

APPENDIX A. ENGINEERING DESIGN AND CONSTRUCTION CHARTER $\ldots \ldots \ldots \ldots \ldots$ A-1

APPENDIX B. MEMBERS OF THE ED\&C REENGINEERING TEAM $\ldots \ldots \ldots \ldots \ldots \ldots \ldots$ B-1

APPENDIX C. SUBTEAM REPORTS $\ldots \ldots \ldots \ldots \ldots \ldots \ldots \ldots \ldots \ldots \ldots \ldots \ldots \ldots \ldots \ldots$ C-1

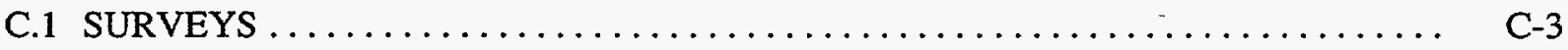

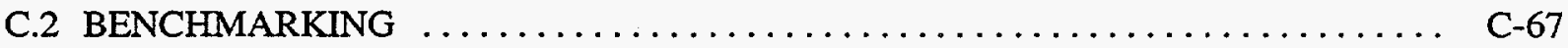

C.3 DAVIS-BACON DETERMINATION $\ldots \ldots \ldots \ldots \ldots \ldots \ldots \ldots \ldots \ldots \ldots \ldots \ldots \ldots \ldots \ldots \ldots$

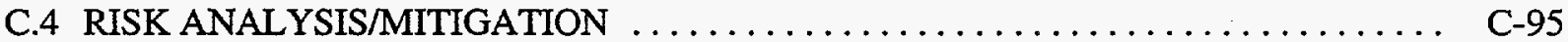

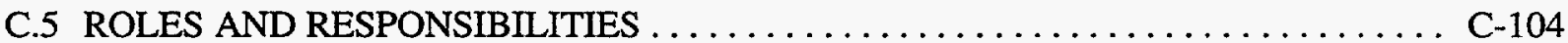

C.6 LMER CONTRACTING AUTHORITY AND EXPERIENCE . . . . . . . . . . C C-120

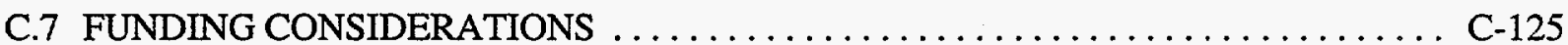

C.8 PERFORMANCE MEASURES $\ldots \ldots \ldots \ldots \ldots \ldots \ldots \ldots \ldots \ldots \ldots \ldots \ldots \ldots \ldots \ldots \ldots \ldots$ 


\section{LIST OF FIGURES}

Figure

Page

$1 \quad$ Process map for short-form construction data sheet $\ldots \ldots \ldots \ldots \ldots \ldots \ldots \ldots \ldots$

2 Current engineering design and construction approach $\ldots \ldots \ldots \ldots \ldots \ldots \ldots \ldots \ldots$

3 Comparison of the current engineering design and construction approach

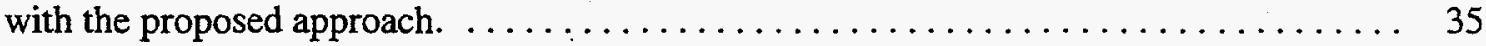

$4 \quad$ Use of a diverse set of design and construction contractors to increase flexibility $\ldots \ldots .36$

\section{LIST OF TABLES}

Table

Page

1 Design approaches used by benchmarked organizations

Construction management and labor approaches used

by benchmarked organizations

Construction approaches used by benchmarked organizations $\ldots \ldots \ldots \ldots \ldots \ldots \ldots$

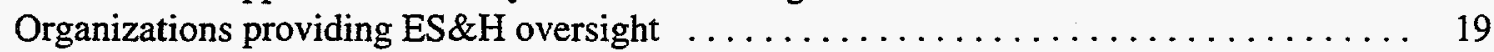

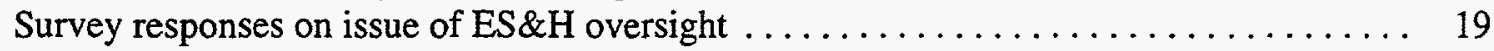

Projected changes in numbers and affiliation of FTEs

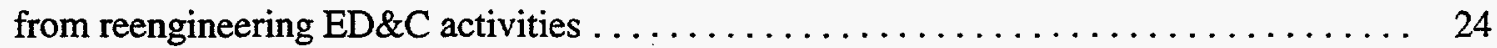

$7 \quad$ Methods used by DOE Energy Research multiprogram laboratories to

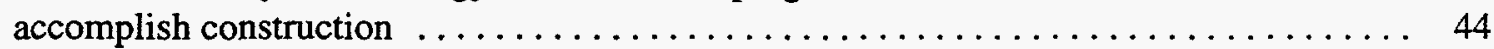

8 Estimated costs for activities necessary for implementing

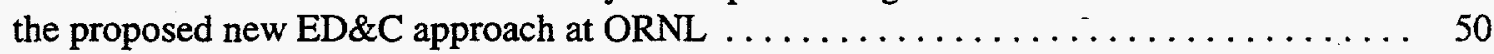

9 Scheduled completion dates for activities necessary for implementing the proposed new ED\&C approach at $\mathrm{ORNL} \ldots \ldots \ldots \ldots \ldots \ldots$ 



\section{ACRONYMS}

\begin{tabular}{|c|c|}
\hline $\mathrm{ADS}$ & Activity Data Sheet \\
\hline $\mathrm{A} / \mathrm{E}$ & architect and engineering \\
\hline AEDC & Arnold Engineering Development Center \\
\hline $\mathrm{AFL}-\mathrm{CIO}$ & American Federation of Labor and Congress of Industrial Organizations \\
\hline AIA & American Institute of Architects \\
\hline ALARA & as low as reasonably achievable \\
\hline ANL & Argonne National Laboratory \\
\hline ARDEC & Armament Research, Development, and Engineering Center (U.S. Army) \\
\hline ASME & American Society of Mechanical Engineers \\
\hline ATLC & Atomic Trades and Labor Council \\
\hline $\begin{array}{l}\mathrm{BNL} \\
\mathrm{BOA}\end{array}$ & $\begin{array}{l}\text { Brookhaven National Laboratory } \\
\text { basic ordering agreement }\end{array}$ \\
\hline CAMP & Capital Assets Management Program \\
\hline CAS & Cost Accounting System \\
\hline CDR & conceptual design report \\
\hline CFC & certified for construction \\
\hline CID & Construction Interface Document (change order) \\
\hline CII & Construction Industry Institute \\
\hline $\mathrm{CM}$ & construction manager \\
\hline COTR & Contracting Officer's Technical Representative \\
\hline CTD & Chemical Technology Division (ORNL) \\
\hline DAF & departmental added factor \\
\hline DBA & Davis-Bacon Act \\
\hline DEAR & Department of Energy Acquisition Regulations \\
\hline DNFSB & Defense Nuclear Facilities Safety Board \\
\hline DOE & Department of Energy \\
\hline DOE-HQ & Department of Energy Headquarters \\
\hline DOE-ORO & Department of Energy Oak Ridge Operations \\
\hline DOL & Department of Labor \\
\hline ECMD & Engineering and Construction Management Division (ORNL) \\
\hline $\mathrm{ED} \& \mathrm{C}$ & engineering design and construction \\
\hline $\mathrm{EM}$ & Environmental Management (DOE) \\
\hline EMEF & Environmental Management and Enrichment Facilities \\
\hline EMR & Experience Modification Rate \\
\hline EPA & U.S. Environmental Protection Agency \\
\hline EPIC & Environmental Management Program Integrating Contractor (projects) \\
\hline ER & Environmental Restoration (as used in Appendix C.1) \\
\hline ES\&H & environment, safety, and health \\
\hline ESO & Engineering Service Order \\
\hline ESPC & energy-savings performance contractor \\
\hline ETD & Engineering Technology Division (ORNL) \\
\hline
\end{tabular}




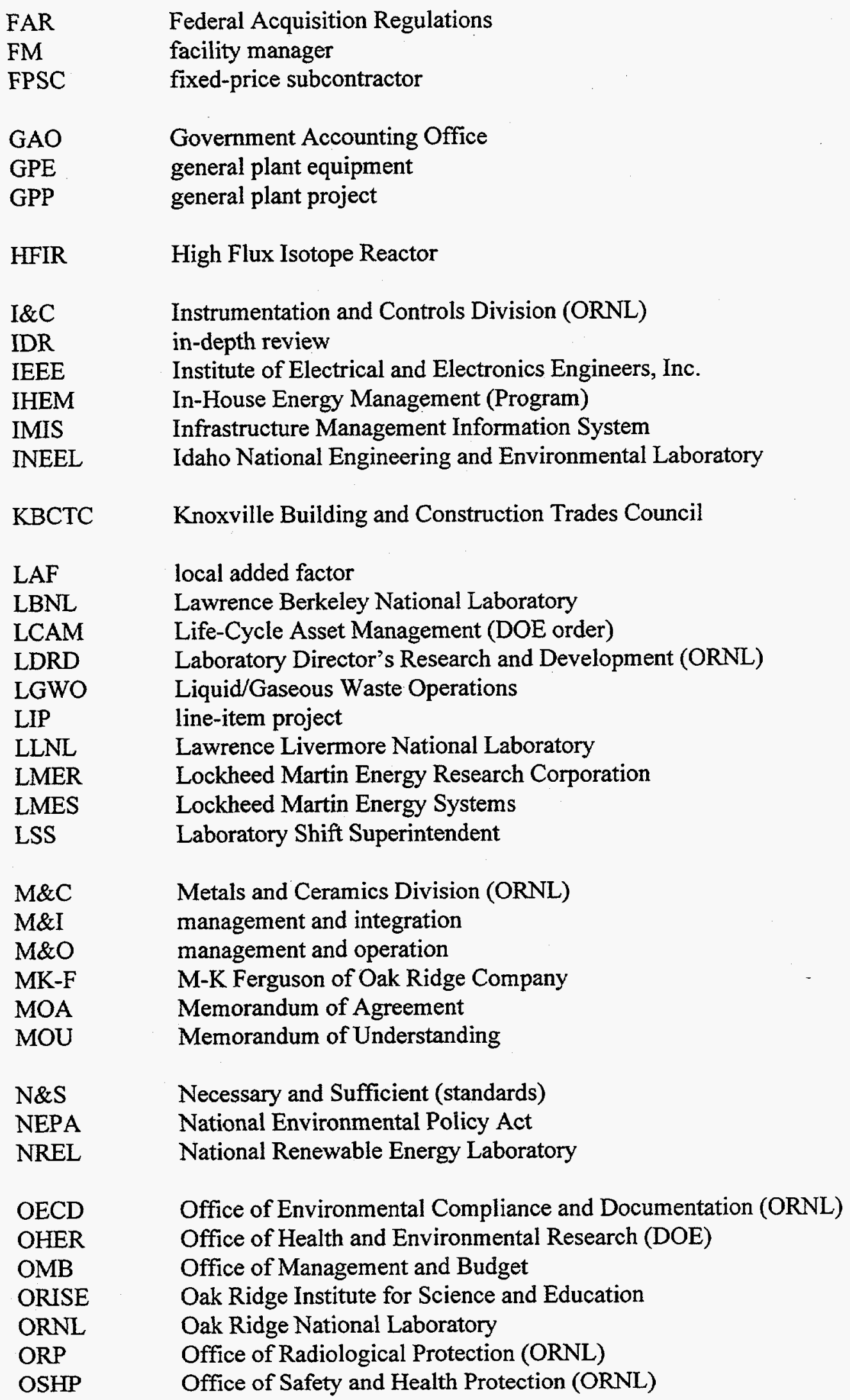


P\&E Plant and Equipment Division (ORNL)

PAAA Price-Anderson Amendments Act

PDR predesign review

PJ project engineer

PLA Project Labor Agreement

PM project manager

PNNL Pacific Northwest National Laboratory

R\&D research and development

RED responsible engineer/designer

RFP request for proposal

RRD Research Reactors Division (ORNL)

SCA Service Contract Act

SHEST Safety and Health Evaluation and Support Team

SIC Standard Industrial Codes

SME $\quad$ subject matter expert

SNS Spallation Neutron Source

SRD Systems Requirements Document

TDEC Tennessee Department of Environment and Conservation

TEC total estimated cost

TVA Tennessee Valley Authority

UST underground storage tank

UT The University of Tennessee, Knoxville

WFO Work for Others

WMRAD Waste Management and Remedial Action Division (ORNL) 



\section{EXECUTIVE SUMMARY}

A team composed of individuals representing research and development (R\&D) divisions, infrastructure support organizations, and Department of Energy (DOE)-Oak Ridge Operations was chartered to reengineer the engineering, design, and construction (ED\&C) process at Oak Ridge National Laboratory (ORNL). The team recognized that ED\&C needs of both R\&D customers and the ORNL infrastructure program have to be met to maintain a viable and competitive national laboratory. Their goal was to identify and recommend implementable best-in-class ED\&C processes that will efficiently and costeffectively support the ORNL R\&D staff by being responsive to their programmatic and infrastructure needs.

The team conducted process mapping of current and potential ED\&C approaches, developed idealized versions of ED\&C processes, and identified potential barriers to an efficient ED\&C process. Eight subteams were assigned to gather information and to evaluate the significance of potential barriers through benchmarking, surveys, interviews, and reviews of key topical areas (Sect. 1) in order to determine whether the perceived barriers were real and important and whether they resulted from laws or regulations over which ORNL has no control. Subteam reports are provided as Appendices C.1-C.8 to the main body of the report:

C.1: Surveys;

C.2: Benchmarking;

C.3: Regulations, Acts, and Contract Language Covering ED\&C;

C.4: Risk Management;

C.5: Roles and Responsibilities;

C.6: Contracting;

C.7: Funding Issues; and

C.8: Performance Measurement.

The team's principal findings, derived primarily from the subteam reports, are contained in the description of the current situation in Sect. 2. Strategies for overcoming barriers and facilitating access to cost-effective, high-quality ED\&C services were then devised. These are expressed as a set of recommendations for changes to the current ED\&C process in 14 specific areas, accompanied by a set of 11 guiding principles for their implementation (Sect. 3).

The team's principal conclusions are that a major overhaul of the current ED\&C process is needed to eliminate inefficiencies, lower costs, increase customer control, provide flexibility, and increase performance in support of ORNL missions. Since 1990, construction costs have increased dramatically, by a total of about $40 \%$. The use of a construction manager accounts for $20 \%$ to $30 \%$ of the increase, with the remainder divided between increased environmental, safety, and health (ES\&H) requirements and use of a Project Labor Agreement (PLA).

The team's 14 recommendations resulting from reengineering the ED\&C process are as follows:

1. ORNL should not utilize a general construction manager; however, large complex projects should be evaluated on a case-by-case basis to determine whether use of a construction manager is warranted. 
2. ORNL should not enter into a general PLA; instead, ORNL should require construction contractors to develop project-specific labor agreements that are mutually beneficial to ORNL and the construction contractor.

3. $R \& D$ division directors and the Infrastructure Program Manager should be responsible and accountable for programmatic- and Landlord-funded ED\&C projects, respectively.

4. R\&D divisions and the Infrastructure Program Manager should have direct access to ED\&C contractors and support personnel through a number of options based on flexible, innovative contracting practices facilitated or managed by the ORNL Engineering and Construction Management Division.

5. ORNL should select and award contracts only to highly qualified ED\&C firms that have demonstrated commitment to end-user satisfaction, project performance, worker safety, and environmental compliance.

6. Construction contractors should be held accountable for ensuring that work is executed in accordance with applicable codes and standards, including ORNL Necessary \& Sufficient Standards, and should be held accountable for all activities occurring on their construction site, including issues involving safety and environmental compliance.

7. Independent ES\&H oversight of construction and construction-like activities should be conducted by only one ORNL overhead organization. The project manager should be responsible for all aspects of an assigned construction project. All recommended ES\&H actions, except those involving imminent danger, should be resolved by the ORNL project manager.

8. The ORNL Davis-Bacon review process should be streamlined.

9. The ORNL Engineering and Construction Management Division should develop a set of performance measures that is responsive to the needs of ORNL end users and the DOE ORNL Site Office and that can be applied in a graded approach to specific projects by project managers.

10. The method used to collect and distribute costs for ORNL ED\&C activities, including administering design and construction contracts, should reflect actual costs to the end users of ED\&C services.

11. The ORNL Infrastructure Program Manager should be responsible and accountable for determining how to upgrade the ORNL atlas drawings and existing facility drawings and for utilizing configuration management for the infrastructure support area in a prioritized manner.

12. A more formal Risk Management Program covering ED\&C activities should be implemented within the ORNL Engineering and Construction Management Division.

13. ORNL and DOE-Oak Ridge should minimize delays in implementation of ED\&C projects.

14. ORNL should integrate the processes for planning and justifying infrastructure projects and ORNL programmatic strategic planning. 
Additional elaboration is provided in Sect. 3 for some of the recommendations, along with a summary of the rationale for each. The underlying rationale is detailed in the review of the current situation in Sect. 2.

A proposed new approach for ED\&C was synthesized (Sect. 4), and cost savings from its implementation were estimated (Sect. 5). A reduction of 25 to $40 \%$ in costs of ED\&C projects appears to be achievable with a relatively small initial investment of $\$ 500,000$. A major benefit is that ORNL will be able to compete successfully for a greater fraction of Landlord funds and should experience a one-third increase in useful construction for a given capital expenditure. Sixty percent of the cost reduction should accrue within months, and the remainder within 2 to 3 years as the proposed process matures. An overall reduction in the number of full-time equivalents (FTEs) involved in ED\&C activities is also expected. Due to the recommended changes in roles and responsibilities associated with the ED\&C process, it is estimated that ORNL will utilize the equivalent of six additional FTEs from existing staff to support construction activities.

Finally, the team developed key elements of an implementation plan for the new ED\&C approach (Sect. 6). 


\section{APPROACH}

The charter for reengineering the engineering design and construction (ED\&C) process was provided by the Reengineering Steering Committee at Oak Ridge National Laboratory (ORNL). ED\&C Reengineering Team members were selected to provide expert knowledge of the current process and to ensure that the viewpoints of the users and sponsors of ED\&C activities were represented. The team included representation from ORNL research and development (R\&D) divisions, support divisions, ORNL infrastructure management, the ORNL Engineering and Construction Management Division (ECMD), the Department of Energy (DOE) ORNL Site Office, and DOE-Oak Ridge Operations (DOE-ORO) Engineering.

After reviewing the literature on reengineering, the team developed an approach for reengineering the ED\&C process that consisted of the following elements:

- Develop vision and goals.

- Map current ED\&C process.

- Visualize "ideal" ED\&C process.

- Identify barriers that must be overcome to realize the "ideal" ED\&C process.

- Assign subteams to investigate barriers, conduct benchmarking and surveys to gather needed information, and develop findings.

- Develop recommendations that will lead to a proposed new ED\&C process.

- Propose new ED\&C process and develop an implementation plan.

These elements are described in the sections that follow.

\subsection{VISION AND GOAL DEVELOPMENT}

Using the charter (Appendix A) provided by the ORNL Reengineering Steering Committee as a starting point, the Reengineering Team developed vision and goal statements:

Vision-ORNL has engineering design and construction processes which fully support the ORNL R\&D mission while being sensitive to the requirements of the R\&D staff.

Goal-To identify and recommend implementable best-in-class engineering design and construction processes which will efficiently and cost-effectively support the ORNL R\&D staff by being responsive to their programmatic and infrastructure needs.

These statements were used to help focus the team activities on the overall objective throughout the reengineering effort.

\subsection{PROCESS MAPPING}

Process mapping was used to detail the steps in the current ED\&C process at ORNL. Process mapping was undertaken by the entire reengineering team, assisted by a facilitator. This activity served to familiarize the engineering team with all aspects of the current ED\&C process. Although all the members of the team had considerable experience with ED\&C activities, most were not completely familiar with 
all aspects of the process, which range from project identification to operational startup of completed facilities. The process mapping also identified organizational interface issues, lengthy process steps, and process inefficiencies. An example of a process map developed for one portion of the ED\&C process is shown in Fig. 1.

\subsection{IDEAL PROCESS IDENTIFICATION}

After extensive discussion about the inefficiencies of the current ED\&C process at ORNL, "ideal" ED\&C processes for executing several types of projects were developed. The ideal versions are less detailed than the process maps developed by the team and provided benchmarks for development of ED\&C processes without constraints. Processes were constructed for both infrastructure support and R\&D projects. These ideal or "clean sheet" approaches to ED\&C helped to consolidate the team's thinking and to assist in identifying barriers to execution of the "ideal" process.

\subsection{BARRIER IDENTIFICATION}

A major team effort was devoted to identification of perceived barriers to effective execution of the ideal ED\&C process. A list of potential barriers was developed through team brainstorming sessions and review of the process maps, while keeping the team's goals and ideal processes in mind. Potential barriers to reengineering were listed initially without regard for the actual effect on the ED\&C process or for the root cause underlying the particular barrier. The potential barriers were then grouped into related areas, and subteams were assigned to investigate a related group of potential barriers. Six subteams were assembled to evaluate the following areas:

- Davis-Bacon/Project Labor Agreement (PLA)/Construction Manager,

- Project Risk,

- Roles and Responsibilities,

- Contracts,

- Funding Considerations, and

- Performance Measures.

Additionally, a survey subteam and a benchmarking subteam were identified to gather information to support evaluations by the subteams, as well as by the full reengineering team.

\subsection{BENCHMARKING AND SURVEYS}

Benchmarking was conducted to determine how other DOE laboratories, universities, and similar institutions-eight in all-perform ED\&C, with the goal of understanding the policies and practices that have worked well for them (Appendix C.2). Most of the benchmarking with DOE laboratories-Argonne National Laboratory (ANL), Brookhaven National Laboratory (BNL), Lawrence Berkeley National Laboratory (LBNL), and Pacific Northwest National Laboratory (PNNL) - was conducted via videoconferences to accommodate the whole benchmarking subteam without the time and expense of travel. Staff from Lawrence Livermore National Laboratory (LLNL) chose to visit ORNL, and one member of the benchmarking subteam performed a site visit to LBNL. The benchmarking subteam also visited The University of Tennessee. Telephone discussions were held with staff from the National Renewable Energy Laboratory (NREL) and the Arnold Engineering Development Center (AEDC). 
Process for Short Form Construction Project Data Sheet

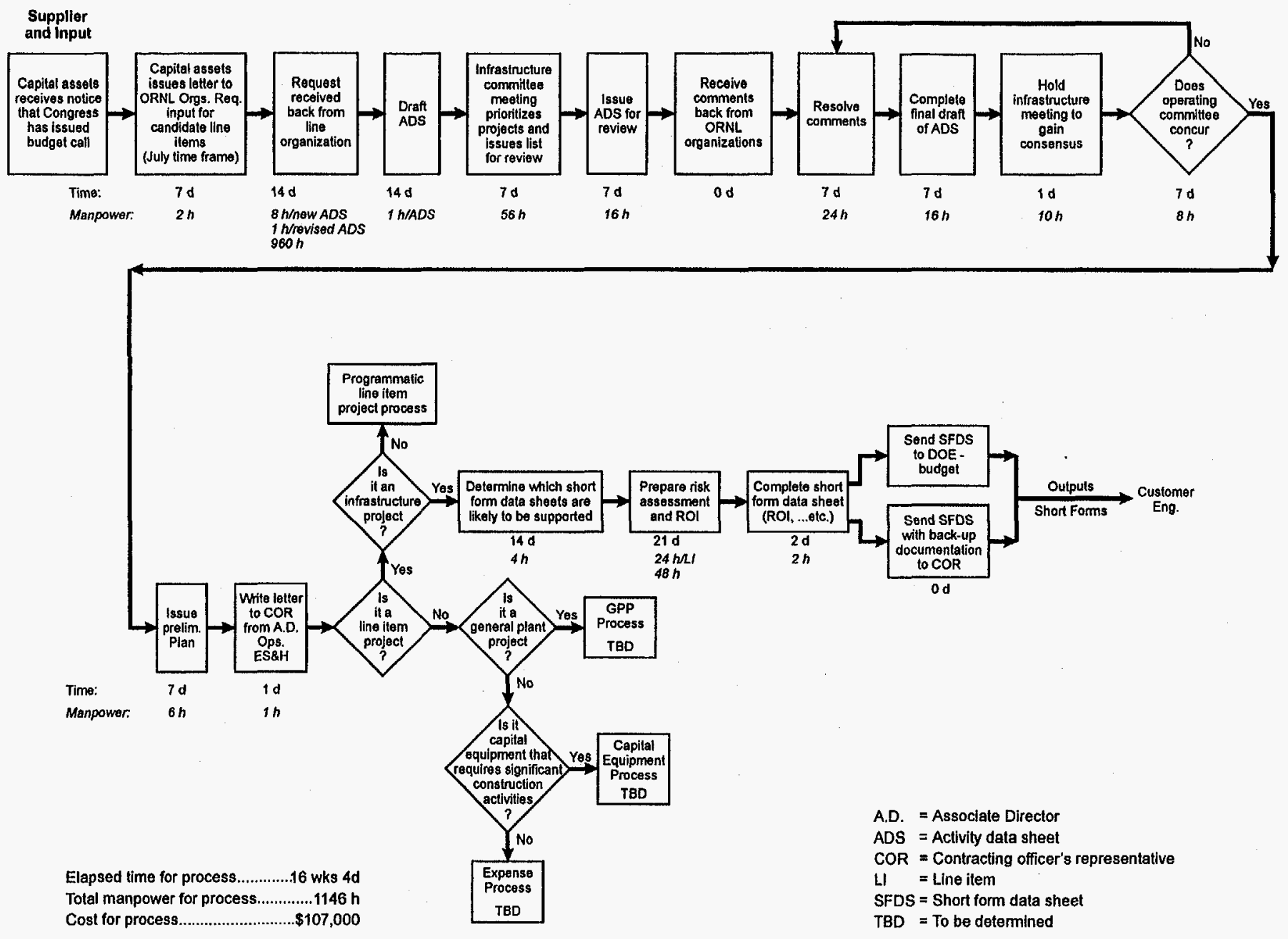

Fig. 1. Process map for short-form construction data sheet. 
Another subteam developed survey questionnaires to gather information from a wider range of individuals. This was done both to verify the experiences of team members and to obtain input from groups not represented on the ED\&C Reengineering Team. Written surveys were sent to four groups: (1) customers of the ORNL ECMD; (2) project engineers in the ECMD; (3) ES\&H personnel; and

(4) construction contractors. Survey questions were tailored to the group being surveyed, but many of the same questions were included to enable cross-comparisons between the four groups.

Details of the groups surveyed, response statistics, and survey results are provided in Appendix C.1. Survey results are also referenced in some subteam reports in support of findings and conclusions, as well as in the description of the current situation in Sect. 2.

\subsection{SUBTEAM INVESTIGATIONS}

Subteams worked independently to investigate the sets of potential barriers assigned to each subteam. The objectives were to (1) better define the potential barriers and their drivers, (2) determine whether the potential barriers were real and important, and (3) ascertain whether the drivers were regulatory or statutory in nature. This information was then used to develop recommendations to remove the root causes in order to develop the most efficient approach to implementing ED\&C processes.

The activities of the subteam varied widely depending on the area of investigation. Interviews were often conducted with individuals involved in a given area. Organizations from which staff were interviewed included MK-Ferguson, outside contractors, DOE-ORO Engineering, and Lockheed Martin. The latter included numerous personnel involved in conducting, using, and overseeing ED\&C activities. Laws, regulations, DOE orders, LMER contracts with DOE, DOE policy, and ORNL policy were reviewed to match perception with reality; that is, to determine whether actual written drivers exist behind all of the barriers. In some cases, the barrier perceived initially was not the real problem, and recommendations were then developed to address the root cause for the real concern. As new information was developed by the subteams, these groups interacted with the full Reengineering Team to allow discussion and to permit redirection of efforts, as necessary.

Detailed subteam reports can be found in Appendices C.3 through C. 8 to this report. The primary findings of the subteams, which were the basis for developing team recommendations, are also discussed as part of the description of the current situation in Sect. 2.

\subsection{DEVELOPMENT OF TEAM RECOMMENDATIONS}

Throughout the reengineering activities, the team met to discuss current and proposed ED\&C processes and subteam information to develop a common understanding and to build consensus for proposed ED\&C approaches. After the subteam investigations were completed, the team considered all subteam recommendations and drafted overall team recommendations, which were mutually agreed upon by a majority of the members. After the recommendations were drafted, a presentation was developed with extensive team input for discussion with the ORNL Reengineering Steering Committee and upper-level management for concurrence and support.

Input from the ORNL Reengineering Steering Committee and upper-level management was reviewed with the team, and necessary changes were made to the recommendations. The final recommendations provided in this report are a result of this team effort with input from all levels of ORNL (Sect. 3). 


\subsection{PROPOSAL FOR NEW ED\&C PROCESS AND ITS IMPLEMENTATION}

A set of 11 guiding principles was developed by the team for implementation of the recommendations for changes to the current ED\&C process (Sect. 3). A proposed new approach for the ED\&C process at ORNL was then synthesized (Sect. 4), and cost savings projected from its implementation were identified (Sect. 5). Finally, the team developed key elements of an implementation plan for the proposed new ED\&C approach (Sect. 6). 


\section{DESCRIPTION OF CURRENT SITUATION}

In 1990, DOE-Oak Ridge significantly changed construction management methods in Oak Ridge by awarding MK-Ferguson a prime contract to manage all construction for the three.DOE sites on the Oak Ridge Reservation. MK-Ferguson, in turn, entered into a PLA with the Knoxville Building and Construction Trades Council (KBCTC). A PLA is a collective bargaining agreement between a company and union construction workers or their representatives. In the present case, the PLA contains a no-strike clause and defines wages/benefits, work rules, grievance procedures, jurisdictional disputes, etc. At about the same time, the emphasis on ES\&H issues increased dramatically. The total effect of changes in 1990 was dramatically increased construction costs.

Construction is defined by the Davis-Bacon Act to be construction, alteration, and/or repair, including painting and decorating exceeding $\$ 2000$. Therefore, most Landlord-funded infrastructure projects and programmatically funded projects are construction work. The Lockheed Martin Energy Research Corporation (LMER) contract prohibits construction by internal labor forces; currently, all construction must be managed and subcontracted by MK-Ferguson. Construction cost and timeliness are of the utmost importance to the success of programs at ORNL. However, at present, a small job that is ruled to be construction usually costs considerably more and takes longer than the same job would if accomplished by having ORNL directly access a construction contractor.

A detailed analysis of the current situation was conducted using the approaches described in Sect. 1 . The results have been grouped into ten major categories for purposes of presentation: (1) Davis-Bacon determination, (2) planning, (3) contracting, (4) design, (5) construction, (6) ES\&H oversight, (7) risk management, (8) project closeout, (9) funding, and (10) performance measurement. The construction situation is described with respect to (1) recent history, (2) the construction manager, (3) the PLA, (4) ES\&H, (5) roles and responsibilities, (6) contracts, and (7) high-risk contractors.

\subsection{DAVIS-BACON DETERMINATION}

At the present time, the process for making Davis-Bacon Act determinations is seen by many end users to be burdensome, time-consuming, and in some way responsible for ED\&C problems at ORNL-at least for small projects. The Reengineering Team, however, concluded that the Davis-Bacon ruling process is not the problem; rather, the problem results from the current DOE-Oak Ridge requirements that dictate use of a general construction manager and its associated general PLA for all ORNL projects. Under current DOE-Oak Ridge requirements, any work that is ruled Davis-Bacon construction cannot be performed by internal labor forces or by directly contracted external labor but must be performed via the required external general construction manager, with a resulting negative impact on cost and schedule for small- to medium-sized projects. End users may attempt to avoid a ruling of Davis-Bacon-covered construction or may argue with the ruling of the Labor Standards Committee in an attempt to avoid serious cost and schedule impacts. In many cases, the end users have little choice; they simply cannot afford to have the work done if the work is ruled to be construction. Frequently, this results in deferral or cancellation of needed projects.

The Davis-Bacon Act was enacted on March 3, 1931, to require the payment of prevailing wage rates for laborers and mechanics employed on the site of federal government contracts for construction, alteration, and/or repair, including painting and decorating, of public buildings or public works. The act requires contractors and subcontractors working on federal construction contracts of $\$ 2000$ or more to pay their 
workers no less than the prevailing wages paid to laborers in the same area on similar projects. Determinations as to local prevailing wages are made by the Secretary of Labor, and rules and regulations related to the Davis-Bacon Act are made by the Department of Labor. The important point is that the Davis-Bacon Act determines only wages paid to workers on defined federal government construction work.

The related Service Contract Act was enacted in 1965 to require the payment of prevailing wage rates for employees of contractors and subcontractors furnishing services to, or performing maintenance service for, federal agencies. The Service Contract Act applies to service contracts in excess of $\$ 2500$. Again, determinations as to local prevailing wages are made by the Secretary of Labor, and rules and regulations related to the Service Contract Act are made by the Department of Labor.

Determination of whether proposed work is covered by the Davis-Bacon Act or the Service Contract Act involves three sequential review committees made up of staff from LMER, Lockheed Martin Energy Systems (LMES), and/or DOE-ORO. Details of the determination process are described in LMES procedure MA-101, Application of Federal Labor Standards, and in the training manual for the LMES course, Application of Federal Labor Standards. Essentially, final authority for the determination is the DOE Labor Standards Committee; however, DOE labor standards guidelines allow site coordinators and committees to handle approximately $90 \%$ of requests. All work determined to be covered by the Acts and the requests which are questionable are sent to the DOE-ORO Labor Standards Committee. Labor standards rulings are posted in a reading room for review by the Atomic Trades and Labor Council (ATLC) and the KBCTC.

The Labor Standards Determination process is regarded as being a problem by end users and project engineers and managers. In surveys conducted as part of reengineering studies, $68 \%$ of project engineers and managers indicated that they experienced schedule delays because of the time required for rulings. Fifty percent of the end users had to interact twice with the Labor Standards Committee to receive a ruling, and $57 \%$ reported interacting with the committee because of disagreements about rulings. To be sure, there are inefficiencies in the review process. The system is still based on paper forms that have to move through the mail, and the three-site committee process is inefficient. However, the majority of problems seem to be a result of end users trying to avoid the inefficient construction process available to ORNL, a situation that stems from the DOE-Oak Ridge requirement that a general construction manager be utilized. It is interesting to compare ORNL's situation with that of other DOE laboratories. All the DOE laboratories benchmarked by the Reengineering Team use essentially the same labor standards determination process. At these facilities, labor standards determination is not an issue because the laboratories do not use a construction manager and have flexibility in how they contract construction work. In fact, some laboratories view the labor standards process as a useful, objective measure to minimize contention over work assignments between in-house maintenance crafts and external buildingtrades crafts.

Work ruled to be covered by the Davis-Bacon Act is considered construction work and cannot be performed by ORNL Plant and Equipment (P\&E) Division crafts because of restrictions in the LMER contract limiting the corporation to conduct of maintenance work. Restrictions of LMER and LMES contracts and the Memorandum of Understanding (MOU) between LMER and LMES as it pertains to directly contracting for construction will be covered in more detail in the contracts section of this report. The end result is that, essentially, LMES is not currently allowed to directly contract for construction work; at the present time, LMER obtains construction services through LMES. 


\subsection{PLANNING}

Planning and communication were identified by the Reengineering Team as serious barriers to successful performance of ED\&C. For example, lack of planning and full communication causes delays in the Davis-Bacon review process, as previously described. In many cases, lower-cost alternatives are not considered during project formulation. Compliance office directors have stated that early involvement of ES\&H staff in formulating project requirements and the timely completion of required documentation are sometimes less than desirable and are highly dependent on the individual divisions. Of the ES\&H personnel responding to the survey, $40 \%$ stated that no ES\&H staff participated in development of the Systems Design Requirements for their projects.

Inadequate lines of communication and poorly defined lines of authority and responsibility result in lessthan-desirable project implementation for both programmatic- and Landlord-funded ED\&C projects. Twenty percent of project customers stated that they had no involvement in development of Systems Design Requirements for their projects. Over $50 \%$ of end users stated that efforts to manage the marginal cost risk associated with their projects were insufficient to totally insufficient. Lack of continuity of personnel through the life of a project also results in delays and in less-than-desirable performance in some cases.

\subsection{CONTRACTING}

Contracting approaches for engineering design services and construction have a major impact on the current performance of projects in Oak Ridge. Currently, engineering design services are provided through DOE contracts to various architect and engineering (A/E) firms. Any work performed by these A/E firms is contracted and managed by the designated DOE Engineering Project Manager. DOE has maintained prime engineering contracts as a basis for controlling the overall design of facilities for scope, cost, and consistency across the Oak Ridge Reservation. ORNL currently subcontracts engineering support services for nonconstruction activities.

DOE has controlled construction in the past through prime contracts. More recently, DOE has utilized the services of a general construction manager to manage all construction activities at DOE-ORO sites. The purpose of this general construction manager contract was to gain efficiencies through a large volume of construction projects. MK-Ferguson of Oak Ridge is the current general construction manager and is now under contract to LMES. ORNL obtains services from this general construction manager through an MOU with LMES.

A number of problems with these contracting approaches were identified. From a construction contractor's point of view, the most important was overly complex and restrictive requirements that minimize flexibility for creative and cost-effective design and construction arrangements. In addition, many contractors felt that ES\&H requirements were excessive and added no value in worker safety and environmental protection. From a customer's point of view, lack of involvement and control was a key issue. Fifty-two percent of customers responding to our survey said they had no involvement in design contractor selection, despite the fact that they were the programmatic customer. Nevertheless, the level of satisfaction in involvement in the actual design effort was reasonably high ( $80 \%$ being neutral to very satisfied). For ES\&H staff, over $83 \%$ of those responding stated that they had no involvement in design contractor selection. 
In the area of the general construction manager, customers were very dissatisfied with the performance of MK-Ferguson. In general, $62 \%$ of construction customers are dissatisfied or completely dissatisfied. In both the cost and schedule areas, over $80 \%$ of customers are dissatisfied or completely dissatisfied with the MK-Ferguson performance. The lack of contracting flexibility for performing construction at ORNL is considered to be a major problem by the Reengineering Team.

Finally, in both design and construction contracts, the excessive numbers of handoffs required for review, approval, and other decisions cause delays and negative cost impacts (Fig. 2). Streamlining the review and approval processes would be highly desirable. In addition, the current serial approach to design and construction contract placements (as opposed to design/construction approaches tailored to the needs of a given project) causes significant delays in overall project completion and loss of the important beneficial synergism between the designer and the constructor. Delays result from the excessive number of handoffs and interfaces associated with the current process (Fig. 2). "Overdesign" of projects results from loss of communication between the designer and the end user, coupled with lack of feedback from the constructor. Accountability is fragmented because each entity is trying to satisfy an intermediate customer (Fig. 2), rather than focusing on the end user's needs.

\subsection{DESIGN}

The Reengineering Team believes that the increased cost and the uncertain quality of the existing engineering design process are related to the present method of contracting for design services-thick and complicated specification documents replete with DOE orders and procedures, unclear roles and responsibilities, and poor communication. In surveys, $42 \%$ of end users reported being unsatisfied with past design services.

LMER presently does no major construction design in-house and obtains design services only through DOE prime contracts to A/E firms. Any work performed by A/E firms goes through the designated DOE Engineering Project Manager, who serves as the contracting officer's technical representative. For years, DOE has held the prime engineering contract to control scope and cost and provide consistency and uniformity across the DOE-ORO sites. The prime contractors provided checks and balances against the Management and Operation (M\&O) engineering organizations and vice versa. A major disadvantage of the present arrangement is poor communication between end users and $\mathrm{A} / \mathrm{E}$ firms. End users interface with the ORNL ECMD, which in turn interfaces with LMES Engineering. LMES Engineering interfaces with $D O E$ Engineering, which interfaces with an $A / E$ firm. Interviewed $A / E$ firms report having to go through several channels to finally reach LMER project or design representatives. Another negative factor is uncertainties about qualifications of the selected $\mathrm{A} / \mathrm{E}$ firm, which, as discussed in the following paragraphs, cause costly design reviews to be built into contracts. The principal advantage, from the LMER point of view, is that under the present arrangement, DOE-ORO pays costs for design contract administration.

Current A/E contracting practices and LMES/LMER engineering culture and tradition result in thick and complicated specifications that have negative cost impact: at the present time, most contracts with $\mathrm{A} / \mathrm{E}$ firms are between $1 / 2$ and 2 in. thick. In comparison, a standard commercial contract typically contains approximately 15 pages with uniform language that is used throughout the industry. A common format used is the American Institute of Architects contract. The format is simple, is easily understood, and clearly lays out requirements for the $\mathrm{A} / \mathrm{E}$. Commercial work is built on trust and long-term relationships, in which increased flexibility in the development of the scope of work allows the client and $\mathrm{A} / \mathrm{E}$ to jointly develop solutions. However, LMER end users, project engineers, and managers have little input 


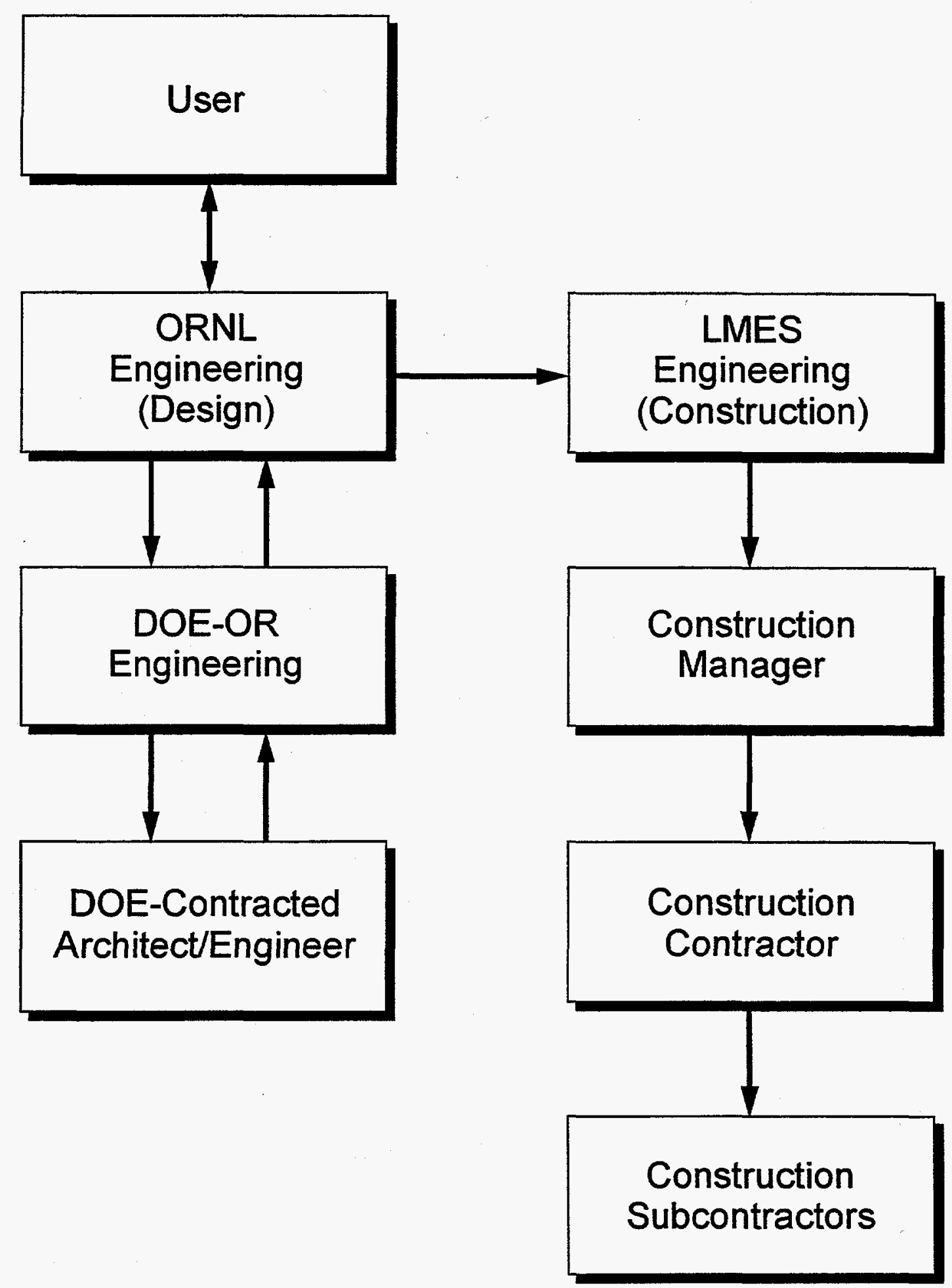

Fig. 2. Current engineering design and construction approach. 
into $\mathrm{A} / \mathrm{E}$ selection. In surveys, $47 \%$ of project engineer/managers and $67 \%$ of end users say they were not involved at all or were only slightly involved in selection of the design contractor. Consequently, to reduce risk, contracts specify multiple reviews, considerable oversight, multiple submittal requirements, extensive design documents, reports, and calculation records. The LMER end user, project engineer, or manager has no choice. If a high-risk, inexperienced $\mathrm{A} / \mathrm{E}$ contractor is ultimately chosen for the project, all of the A/E's work must be checked carefully, at considerable cost to the end user, or the final product may have to be reworked to meet specifications. However, current review and submittal requirements are an unnecessary, costly burden if experienced, talented AVE firms are chosen.

DOE-ORO's approach to A/E contracting is undergoing change. DOE has recently approved conceptual design reports showing the $M \& O$ managing the design process through the awarding of an $A / E$ contract and has indicated that future A/E contracting may be the responsibility of DOE prime $M \& O$ and Management and Integration (M\&I) contractors. The new approach is consistent with practices at the DOE Energy Research laboratories, as summarized from benchmarking studies (Table 1). All national laboratories that were benchmarked directly manage the design process, directly contract for $\mathrm{A} / \mathrm{E}$ design, or perform design in-house. ANL, LBNL, BNL, and NREL use prequalified design contractors selected by using guidelines of the Brooks Act, which allows selection based on competence at fair and reasonable prices.

Table 1. Design approaches used by benchmarked organizations ${ }^{a}$

\begin{tabular}{|c|c|c|c|c|c|c|c|c|c|c|}
\hline \multirow{2}{*}{ Approach } & \multirow{2}{*}{ ORNL } & \multirow{2}{*}{ ANL } & \multirow{2}{*}{ LBNL } & \multirow{2}{*}{ BNL } & \multicolumn{2}{|c|}{ PNNL } & \multirow{2}{*}{ LLNL } & \multirow{2}{*}{ NREL } & \multirow{2}{*}{ UT } & \multirow{2}{*}{ AEDC } \\
\hline & & & & & Gov & Priv & & & & \\
\hline In-house & & $\mathrm{x}$ & $\mathrm{X}$ & $\mathrm{X}$ & $\mathrm{X}$ & $\mathrm{X}$ & $\mathrm{x}$ & & & $\mathrm{X}$ \\
\hline Time and materials & & $\mathrm{X}$ & $\mathrm{X}$ & $\mathrm{X}$ & & & & & $\mathrm{X}$ & \\
\hline Prequalified contractors & & $\mathrm{x}$ & $\mathrm{x}$ & $\mathrm{X}$ & & & $\mathrm{x}$ & $\mathrm{X}$ & & \\
\hline DOE-selected A/E & $\mathrm{X}$ & & & & & & & & & \\
\hline
\end{tabular}

${ }^{\circ O R N L}=$ Oak Ridge National Laboratory; ANL = Argonne National Laboratory; LBNL = Lawrence Berkeley National Laboratory; BNL = Brookhaven National Laboratory; PNNL = Pacific Northwest National Laboratory; LLNL = Lawrence Livermore National Laboratory; NREL = National Renewable Energy Laboratory; UT = University of Tennessee; $\mathrm{AEDC}=$ Arnold Engineering Development Center; Gov = government side; Priv = private side.

Interviewed $\mathrm{A} / \mathrm{E}$ firms report that time required for government design reviews is a major cost factor. Their evaluation is that most are accomplished in an unorganized fashion and last too long. While waiting for reviews to be completed, the $\mathrm{A} / \mathrm{E}$ must find other work for the design staff, which has a negative impact on the A/E's staffing/workload planning and can result in reassignments, which cause loss of continuity. The need for lengthy, formal design review would diminish with better communication between the designer, the end user, and the project manager during the design process. Interviewed $\mathrm{A} / \mathrm{E}$ firms favored building design teams with representatives from the $\mathrm{A} / \mathrm{E}$ and the $\mathrm{M} \& \mathrm{O}$.

Unclear roles and responsibilities also impact design cost in a negative manner. AVE firms report that project managers sometimes lack authority to make decisions. This creates delays and greatly slows design progress by making comment resolution difficult. In many cases, the $A / E$ design manager ends up 
making decisions that should have been made by the end user's project manager. Project managers must be vested with the authority to accomplish the project scope and then be held accountable. However, the project manager must also receive full support from all project team members, including ES\&H support staff, and from facility/system managers for projects that interface with existing facilities or systems.

At the present time, collection and distribution of costs for ORNL ED\&C activities, including those for administering design and construction contracts, are not done in a manner that distributes actual costs to users of engineering and design services. As LMER takes over contract administration responsibilities from DOE-ORO (with related contract administration costs), the uneven distribution of costs becomes even more of a problem. For example, ECMD, which has its own procurement staff, is in essence paying overhead for procurement and related services that are not needed or wanted. This, in turn, drives up costs for users of ECMD.

\subsection{CONSTRUCTION}

There is dissatisfaction ( $67 \%$ or higher) by both ORNL end users and project managers regarding timeliness and cost-effectiveness of construction activities at ORNL. The cost of a general plant project (GPP) office building is about $\$ 160 / \mathrm{ft}^{2}$, compared with Commerce Park office buildings built during 1994-1996 for about $\$ 72 / \mathrm{ft}^{2}$, University of Tennessee (Knoxville) office buildings built during 1996-1997 for about $\$ 72 / \mathrm{ft}^{2}$, and recent BNL buildings built for $\$ 125-\$ 150 / \mathrm{ft}^{2}$. Regarding the BNL costs, it should be noted that the cost of living on Long Island is $40 \%$ higher than the Knoxville area. The reengineering team has identified several causes:

- All other DOE laboratories, as well as The University of Tennessee and Commerce Park, direct their own construction rather than utilizing a general construction manager. Under the current arrangement of utilizing a construction manager and the PLA, ORNL is not competitive.

- Many desirable construction contractors will not do business with ORNL under current conditions. Construction contractors that have the quality and dedication of the constructor of the High Temperature Materials Laboratory will not do business with ORNL today.

- Independent ES\&H oversight at ORNL is conducted by numerous ORNL organizations in an uncoordinated manner, which leads to substantial negative impacts on both project cost and schedule.

- Insufficient formality in roles, responsibilities, authority, and accountability exists for R\&D division directors, the Infrastructure Program Manager, ORNL project managers, ORNL ECMD, LMES Engineering, DOE-Oak Ridge Engineering, and other project participants.

- Specifications are not stated in the straightforward, commercial-type language with which contractors are familiar. Too much emphasis is placed on DOE orders and procedures.

- There is insufficient end-user input into selection of both design and construction contractors.

- Historically, some design and construction contractors have proven to be high risk and/or high cost.

- A formal risk management program covering ED\&C activities is lacking, which limits the extent to which a graded approach is utilized. 


\subsubsection{Recent History}

Prior to 1990, LMES managed non-line-item-funded construction utilizing fixed-price subcontracts, and DOE-Oak Ridge subcontracted line-item-funded work. In 1990, DOE-Oak Ridge changed the method of construction management significantly by awarding MK-Ferguson a prime contract to manage all construction for the three DOE sites on the Oak Ridge Reservation. MK-Ferguson, in turn, entered into a PLA with the KBCTC. All subcontractors to MK-Ferguson must sign the PLA. One clause in the PLA requires the signatories to obtain labor from the KBCTC, with the exception of up to four key employees. The PLA also contains a no-strike clause and defines wages/benefits, work rules, grievance procedures, mechanisms for resolution of jurisdictional disputes, etc.

At about the same time, the emphasis on ES\&H issues increased dramatically. The total effect in 1990 of having a construction manager, a PLA, and increased emphasis on ES\&H was dramatically increased construction costs: just prior to 1990, a GPP office building cost less than $\$ 80 / \mathrm{ft}^{2}$; the next GPP office building cost $\$ 160 / \mathrm{ft}^{2}$. Use of a general construction manager is estimated to have contributed $\$ 30 / \mathrm{ft}^{2}$, with the remaining $\$ 50 / \mathrm{ft}^{2}$ divided between contributions from the PLA and increased ES\&H requirements.

Over the past 7 years, the conditions that motivated DOE to establish the current design and construction approach have changed from two standpoints: the importance of project schedule and the amount of construction activity at the three Oak Ridge sites. Schedules for construction projects at the Oak Ridge Y-12 Plant in 1990 were extremely important because of weapons delivery requirements; cost was of secondary importance. Also, annual construction at the three Oak Ridge sites in 1990 was at a level of about $\$ 300$ million/year. In contrast, the projected GPP budget at ORNL for FY 1998 is $\$ 3.1$ million, and the line-item budget for FY 1998 is $\$ 7.8$ million. Construction cost and, to a lesser extent, project schedule are of utmost importance to the success of programs at ORNL. At present, a small project that is ruled to be construction usually costs considerably more and takes longer than if the same project were accomplished via ORNL's accessing a construction contractor directly.

Under present conditions, ORNL's flexibility to access construction contractors is constrained because DOE-ORO uses the Davis-Bacon Act not only to define what work is construction work but also to determine who manages and accomplishes such work. Factors that lead to this outcome are twofold: (1) most of the ORNL Landlord-funded infrastructure projects and programmatically funded projects are determined to be construction work; and (2) since the LMER/LMES contract prohibits construction by internal labor forces, all construction is managed and subcontracted by MK-Ferguson.

\subsubsection{Construction Manager}

DOE laboratories, The University of Tennessee, and AEDC were benchmarked by the Reengineering Team to compare design and construction methods. With the exception of the government side of PNNL, other DOE laboratories do not use a construction manager, as shown in Table 2 . They all manage their own construction projects with in-house staff and feel very strongly that having control over a project is essential to contain costs and ensure quality. PNNL uses Fluor-Daniel to manage its construction contracts for the Hanford Site but manages its own construction for projects in the privatized part of PNNL. 
Table 2. Construction management and labor approaches used by benchmarked organizations ${ }^{a}$

\begin{tabular}{lcccc}
\hline \multirow{2}{*}{ Approach } & ORNL & ANL LBNL & BNL $\frac{\text { PNNL }}{\text { Gov }}$ Priv LLNL NREL UT AEDC \\
\hline Construction manager & $\mathrm{X}$ & $\mathrm{X}$ & \\
Project Labor Agreement & $\mathrm{X}$ & $\mathrm{X}$ & \\
\hline
\end{tabular}

${ }^{\circ} \mathrm{ORNL}=$ Oak Ridge National Laboratory; ANL = Argonne National Laboratory; LBNL = Lawrence Berkeley National Laboratory; BNL = Brookhaven National Laboratory; PNNL = Pacific Northwest National Laboratory; LLNL = Lawrence Livermore National Laboratory; NREL = National Renewable Energy Laboratory; UT = University of Tennessee; $\mathrm{AEDC}=$ Arnold Engineering Development Center; Gov = government side; Priv = private side.

The use of a third-party general construction manager is estimated to add 25-30\% to the cost of construction for most ORNL projects. In surveys of end users conducted by the Reengineering Team, $81 \%$ were unhappy with both the cost and schedule performance of the general construction manager. In addition, end-user administration costs were increased, as $57 \%$ of customers were dissatisfied with the amount of time they spent initiating and following through on MK-Ferguson projects and $91 \%$ rated the current process for obtaining construction services from the general construction manager as burdensome. The added complication, cost, and schedule of a general construction manager for projects under $\$ 350 \mathrm{~K}$ were strongly felt to be a problem by end users: no customers surveyed thought MK-Ferguson to be best qualified to perform construction activities for projects of this size.

Surveyed project engineers/managers also reported serious problems with the existing general construction manager arrangement: $83 \%$ of project engineers/managers were dissatisfied with the cost performance of the general construction manager, $72 \%$ were dissatisfied with the time required to begin construction work, $61 \%$ were dissatisfied with the schedule performance, and $67 \%$ were dissatisfied with the time required to complete the whole construction process. Similar to end users, project engineers/managers saw increased problems for small construction tasks: $95 \%$ believe that the general construction manager is not the best qualified to perform construction activities under $\$ 100 \mathrm{~K}$, and $78 \%$ believe that it is not the best qualified to perform construction activities under $\$ 350 \mathrm{~K}$.

The use of a third-party general construction manager for smaller projects is inefficient not only because several organizations must be involved but also because construction contractors tend to focus on the needs of the general construction manager rather than those of the end user. As a result, the needs of the end user are not well met.

For very large projects, the use of a construction manager may be advantageous and should be evaluated on a case-by-case basis. Other laboratories sometimes make use of construction managers for very large projects with good success. For example, for the Advanced Photon Source, ANL had a project office that was separate from the laboratory operating organization but was staffed with ANL employees. Rust Engineering was hired to coordinate construction.

\subsubsection{Project Labor Agreement}

The MK-Ferguson PLA is an agreement with the KBCTC, American Federation of Labor and Congress of Industrial Organizations (AFL-CIO). It covers the areas of wages/benefits, work rules, grievance 
procedure, jurisdictional dispute resolution, hours of work, etc., and includes a no-strike clause. Every contractor working for MK-Ferguson must sign the PLA. Contractors are allowed up to four key employees; all others must be hired through the KBCTC. These provisions of the PLA were in effect until September 30,1997. The major advantages of a PLA are the no-strike clause, which ensures that projects will not be delayed by strikes and the long-term agreements on wages, working conditions, benefits, work rules, employee termination, and dispute resolution. The major disadvantages are increased costs (estimated to be 10 to $20 \%$ of project cost) and implementation of stricter jurisdictional work rules than are practiced by construction contractors working in the private sector.

Several DOE laboratories, The University of Tennessee, and AEDC were benchmarked by the Reengineering Team to compare design and construction methods. With the exception of the government (nonprivatized) part of PNNL, other DOE laboratories do not use a PLA (see Table 2). The University of Tennessee, with substantial construction in the same geographical area as ORNL, does not use a PLA, nor does AEDC. Neither facility directs or influences the labor relations of its contractors. Both hire contractors for their competence and allow them to conduct business as they know best, including dealing with labor relations. All of the other DOE laboratories comply with the Davis-Bacon Act, ensuring that contractors pay prevailing wages for work on federal sites, a policy that tends to encourage the use of local labor.

The DOE-ORO Labor Standards Committee believes that a PLA is in the best interest of DOE-ORO, ensuring harmonious labor relations and promoting the use of local labor. MK-Ferguson sees the nostrike/no-walkout/no-slowdown clauses of the PLA and the pool of trained people as advantages and has negotiated a new PLA, which became effective when the previous one expired on September 30, 1997.

For very large projects, the use of a PLA may be advantageous on a case-by-case basis if eliminating the threat of schedule delay due to strikes and slowdowns is deemed to be worth the extra cost. However, ORNL does not have any very large projects at this time, and most ORNL customers would accept a slight risk of delay in return for a significantly lower cost.

Several desirable construction contractors will not bid on work at ORNL under the present construction manager/PLA/ES\&H rules. Contractors who have recently worked at ORNL were surveyed, but it should be kept in mind that $81 \%$ of respondents were union contractors, who presumably would not be as greatly affected by the PLA as nonunion contractors. Contractors were divided on many issues but had fairly strong opinions on others: $64 \%$ of contractors said that the PLA is not essential for harmonious labor practices, $60 \%$ report that work-rule provisions of the PLA result in inefficiencies, and $64 \%$ say that unknown productivity of PLA-referred workers leads to increased bid prices. On the positive side, $82 \%$ say that the PLA provides for peaceful settlement of labor disputes. Six of the most desirable construction contractors, who conduct more than $70 \%$ of the regional construction (excluding residential), indicated a willingness to bid on construction work at ORNL if the use of both a general construction manager and the PLA was eliminated and prequalification of bidders was employed.

\subsubsection{Environment, Safety, and Health}

ES\&H oversight has clearly driven up construction costs at ORNL over the past several years. Dramatically increased oversight was clearly necessary in response to increased emphasis on compliance with DOE ES\&H directives and a change in attitudes about ES\&H from the top level down. However, a number of individual ES\&H groups have overlapping oversight responsibility/authority, which results in a lack of focus, a large number of construction interruptions and differing interpretations of rules for 
construction work. Also, ES\&H staff are often not sufficiently involved in up-front planning as project team members.

End users who were interviewed indicated that ES\&H oversight seems to be moving in the right direction; ES\&H oversight of recent projects has shown improved focus and coordination. These issues are discussed more completely in Sect. 2.6.

\subsubsection{Roles and Responsibilities}

Greater formality is needed in roles, responsibilities, authority, and accountability for R\&D division directors, the Infrastructure Program Manager, ORNL project managers, ECMD, LMES Engineering, DOE-Oak Ridge Engineering and Construction, and other participants. The success of a project, from development of the project scope and cost estimate through construction and startup, is dependent in great part on selection and chartering of the project team. A focused project team effort encompassing all affected organizations is needed to ensure optimum project planning. Gaining the project team's commitment to achieving project goals and objectives is a critical element of project success. Formal chartering of project teams by management is essential to clearly establish roles, responsibilities, and authority for the efficient execution of project activities.

Project managers must be vested with the authority to accomplish the project scope and then be held accountable for meeting project goals and objectives within the budget and on schedule. Project team members must be accountable to the project manager for their participation in the project. For instance, ES\&H personnel assigned to project teams must understand that they are on the team to help identify project requirements, plan for meeting those requirements, and assist in surveillance of project activities to ensure compliance with project plans. For projects that interface with existing facilities or systems, the facility manager must be fully integrated with the project team to ensure adequate consideration of operational interfaces and collateral impacts to ongoing operations. In short, a fully integrated project team that is focused on project goals and objectives is essential to success.

Organizations sponsoring projects must ensure that the scope of their needs is fully identified for the project team. They must also commit the time and resources necessary to support project team activities, especially in the areas of scope definition, design review, construction coordination, and project acceptance and startup. Sponsoring organizations management must accept ownership and ultimate responsibility for the overall success of the project. Poor or inadequate up-front planning adversely affects cost, schedule, and customer satisfaction. All organizations affected by the project are not always involved in project planning. End users who did not fully participate on the project team are more likely to be dissatisfied with project outcome. Contractors noted that "owners" should fully review design documents because they initiate most of the changes during construction. Projects in which all participants were identified at the outset and provided time to discharge their duties were more likely to be perceived as a success.

The current role of the end user in the design process results in customer (end-user) dissatisfaction with the design product. Customers feel isolated from the design activities and feel they have little or no input concerning who does the design. They also feel that their comments on design documents are not uniformly considered. Since DOE holds many of the A/E contracts, there is a problem in defining who the customer is-DOE, the project manager, or the end user. There is the perception, especially on the line-item projects, that $\mathrm{A} / \mathrm{E}$ firms are concerned only with pleasing $\mathrm{DOE}$, not with the project team or end user. A concern also exists that there should be a graded approach to the level of detailed design required for smaller, less complex projects. 
Multilayered ES\&H oversight is perceived as excessive. Consistent interpretation of ES\&H requirements is not always applied during the course of a project. Project managers have limited control over the ES\&H oversight imposed on their projects.

A general concern, expressed by many project participants, was the negative impact of changes in key project personnel. At times, two, three, or even four changes in project management occurred over the course of the project. Lack of continuity in project team participants resulted in inefficiencies, lack of focus, and poor communication. Reassignment of project responsibilities between team members and participating organizations should be minimized.

ORNL should integrate the processes for planning and justifying infrastructure projects and ORNL programmatic strategic planning. A consistent approach to planning, prioritization, and tracking of highpriority infrastructure requirements is needed. Currently, the Infrastructure Management Information System (IMIS) contains data on identified infrastructure needs and proposed programmatic projects. The Capital Assets Management Program (CAMP) prioritization matrix is used to prioritize all projects in IMIS. Programmatic sponsors do not proactively submit information on proposed projects to the Infrastructure Program Manager for inclusion in IMIS. Comprehensive information concerning infrastructure and programmatic requirements is needed to ensure that limited infrastructure program resources are used in a manner consistent with priorities of present and emerging ORNL programmatic requirements.

With respect to the site process for prioritizing infrastructure requirements, $100 \%$ of end users, program sponsors, and project managers interviewed for recently completed ORNL ED\&C projects stated that they were not involved in the ORNL infrastructure prioritization process for selecting needed upgrade projects. Fifty percent of the project managers, $67 \%$ of the project sponsors, and $100 \%$ of the end users were not even aware that a prioritization process existed.

\subsubsection{Contracts}

Specifications are often not stated in the straightforward, commercial-type language with which contractors are familiar; too much emphasis is placed on DOE orders and procedures. The result is that contractors are not willing to bid or they increase bid prices to cover the uncertainty caused by obscure contract provisions. This issue is dealt with in more detail in the section on contracting.

The Reengineering Team benchmark studies revealed that several DOE laboratories make use of innovative, cost-effective contracting procedures, including prequalified contractors under task-order agreements that can respond quickly and effectively to short-turnaround projects (Table 3 ). These projects would typically be $\$ 300,000$ or less. Another technique is the use of labor-hour contracts with building trades based on hourly rates for construction trades that comply with the Davis-Bacon Act. The labor is managed by the laboratory. This issue is also dealt with in more detail in the section on contracting.

\subsubsection{High-Risk Contractors}

Some ED\&C contractors are excellent, but others can only be considered "high risk." High-risk contractors require more surveillance, and their work is usually subject to retrofitting either prior to the end of the project or after the project has been turned over to the facility operator. 
Table 3. Construction approaches used by benchmarked organizations ${ }^{a}$

\begin{tabular}{|c|c|c|c|c|c|c|c|c|c|c|}
\hline \multirow{2}{*}{ Approach } & \multirow{2}{*}{ ORNL } & \multirow{2}{*}{ ANL } & \multirow{2}{*}{ LBNL } & \multirow{2}{*}{$\mathrm{BNL}$} & \multicolumn{2}{|c|}{ PNNL } & \multirow{2}{*}{ LLNL } & \multirow{2}{*}{ NREL } & \multirow{2}{*}{ UT } & \multirow{2}{*}{ AEDC } \\
\hline & & & & & Gov & Priv & & & & \\
\hline In-house labor & & & $\mathrm{X}$ & & & $\mathrm{X}$ & $\mathrm{X}$ & & & $\mathrm{X}$ \\
\hline Labor-hour contracts & & $\mathrm{X}$ & $\mathrm{X}$ & $\mathrm{X}$ & $\mathrm{X}$ & & $\mathrm{X}$ & & $\mathrm{X}$ & \\
\hline Prequalified contractors & $\mathrm{X}^{b}$ & $\mathrm{X}^{c}$ & $\mathrm{X}$ & $\mathrm{X}$ & & $\mathrm{X}$ & $X$ & $\mathrm{X}$ & & \\
\hline
\end{tabular}

${ }^{\circ}$ ORNL = Oak Ridge National Laboratory, ANL = Argonne National Laboratory; LBNL = Lawrence Berkeley National Laboratory; BNL = Brookhaven National Laboratory; PNNL = Pacific Northwest National Laboratory; LLNL = Lawrence Livermore National Laboratory; NREL = National Renewable Energy Laboratory; UT = University of Tennessee; $\mathrm{AEDC}=$ Arnold Engineering Development Center; Gov = government side; Priv = private side.

${ }^{b}$ Limited use of prequalified unit-price contractors through general construction manager.

In limited cases.

Greater use of prequalified ED\&C contractors is necessary to avoid selection of inexperienced, high-risk contractors. All of the DOE Energy Research national laboratories benchmarked by the Reengineering Team utilize prequalified contractors, whereas ORNL is unable to do this under the current ED\&C approach.

Other risks associated with the ED\&C process are discussed in Sect. 2.7.

\subsection{INDEPENDENT ES\&H OVERSIGHT}

Independent ES\&H oversight requirements during the design and construction phases of a project have clearly driven up construction costs at ORNL over the past several years. Dramatically increased attention to ES\&H was clearly necessary in response to increased emphasis on compliance to ES\&H directives and a change in attitudes about ES\&H from the top level of DOE down through the implementing organizations at ORNL. However, it appears that the single most difficult problem is the number of individual independent ES\&H oversight groups that have overlapping oversight responsibility/authority. This results in a lack of focus, a large number of construction interruptions, and differing interpretations of rules for construction (Table 4). Also, independent ES\&H oversight staff are often not involved sufficiently in early evaluation of project hazards.

Based on survey data, $55 \%$ of construction customers, $47 \%$ of project managers/engineers, and $100 \%$ of responding contractors felt that the level of independent ES\&H oversight for construction is excessive at ORNL. For the construction contractors, $100 \%$ believed that project cost was negatively impacted by ES\&H oversight, and $73 \%$ believed that project schedules were delayed. In contrast with these data, $71 \%$ of independent ES\&H oversight personnel responding indicated that ES\&H oversight was insufficient, and $80 \%$ believed that insufficient attention was given to ES\&H risk during project design.

Communication and development of clear roles and responsibilities among these groups are clearly necessary (Table 5). 
Table 4. Organizations providing ES\&H oversight

\begin{tabular}{lc}
\hline \multicolumn{1}{c}{ Organization } & $\begin{array}{c}\text { Number of } \\
\text { observations }\end{array}$ \\
\hline ORNL overhead-funded group & \\
Safety and Health Evaluation and Support Team (SHEST) & $48^{a}$ \\
Radiological Protection & 36 \\
Fire Protection Engineering & 25 \\
Safety Department & 23 \\
Office of Environmental Compliance and Documentation & 22 \\
Office of Operational Readiness \& Facility Safety & 5 \\
& \\
Other & \\
MK-Ferguson ES\&H & 49 \\
ORNL division & 30 \\
LMES Safety \& Health & 12 \\
Engineering Electrical Safety & 11 \\
ATLC Safety & 10 \\
\hline
\end{tabular}

"For example, based on 69 survey responders, 48 observed SHEST providing oversight.

Table 5. Survey responses on issue of ES\&H oversight

- End users

- $55 \%$ believe ES\&H oversight for managing project hazards was excessive

- $59 \%$ believe ES\&H oversight added little or no value to project

- Project managers/engineers

- $47 \%$ believe level of ES\&H oversight was excessive

- $72 \%$ believe ES\&H oversight added little or no value to project

- Contractors

- $100 \%$ believe level of ES\&H oversight was excessive

- $100 \%$ believe project cost was impacted by ES\&H oversight

- $64 \%$ believe ES\&H oversight added little or no value to project

- $73 \%$ believe project schedule was delayed by ES\&H oversight

- ES\&H oversight staff

- $71 \%$ believe level of ES\&H oversight was insufficient

- $80 \%$ believe insufficient attention was given to ES\&H risk during project design

As a follow-up to the survey data collected in the ES\&H area, detailed discussions were held with the key ORNL offices responsible for ES\&H compliance to increase overall understanding of the issues facing these key organizations that presently provide the bulk of compliance-related activities in the construction area. Up-front involvement of ES\&H staff in ED\&C activities is sometimes less than desirable and is dependent on individual ORNL customers. In the Office of Environmental Compliance 
and Documentation (OECD) area, this contact usually comes through the National Environmental Policy Act (NEPA) process; with the Office of Radiological Protection (ORP), it tends to come through the complex leader or the as low as reasonably achievable (ALARA) program. For the Office of Safety and Health Protection (OSHP), the primary point of up-front contact and project review is through the Safety and Health Evaluation and Support Team (SHEST). Since there is a SHEST team member assigned for each project engineer, this communication has significantly improved.

The largest area of concern for these offices is the increased number of DOE-direct projects executed onsite at ORNL and potentially operating outside of ORNL requirements. It was felt that construction subcontractor-provided ES\&H services were not presently adequate in meeting ORNL performance needs, and ES\&H involvement in subcontracting is very low in areas other than safety and health. Oversight of performance is provided and funded by each of these offices, in addition to that contractually required and provided by the construction subcontractors. This is impacting ORNL overhead costs. It was generally thought that project engineers are accepting the responsibilities for ES\&H in their projects but that additional training and knowledge may be needed to improve overall performance.

Generally speaking, construction contractors are not held strictly accountable for ensuring that work is executed in accordance with applicable codes and standards, including ORNL requirements for safety and health. Contracts are not canceled due to violations, nor are past violations grounds for exclusion from future work. Instead, the approach is more one of trying to "inspect" ES\&H performance through these multiple oversight groups, again resulting in increased costs and delayed schedule performance. The Reengineering Team concluded that many of these considerations can be handled through prequalification of construction contractors and by holding contractors accountable for ES\&H activities on their sites.

In order to address the multifaceted ES\&H concerns identified in Sects. 2.4, 2.5.4, 2.5.5, and this section, it is advantageous to group the various ES\&H oversight functions for purposes of evaluation and discussion. It appears that one can identify three basic types of ES\&H staff oversight for ORNL projects, each of which requires a unique approach in order to deal with the associated concerns. The three groups include (1) the independent oversight capabilities provided through ORNL overhead-supported organizations; (2) the ES\&H subject-matter experts who are part of, or directly support, the ED\&C project teams under the ORNL project manager; and (3) external oversight functions such as those provided by construction contractors. A potential solution for concerns about the latter was previously suggested, and recommendations for dealing with the other two ES\&H areas are presented in Sect. 3.

\subsection{RISK MANAGEMENT}

Some risks associated with ED\&C projects can be reduced or eliminated; however, others are unavoidable. Effective management of ED\&C risks requires a stepwise process of risk identification, evaluation, and mitigation. Mitigation costs must be balanced against potential costs or impacts of risks.

A comprehensive, formal approach for managing ED\&C risks is not being utilized at ORNL. ES\&H oversight is being conducted in an inconsistent and uncoordinated manner (Sect. 2.6). The Project Risk Evaluation function within ECMD is not being fully utilized, and a graded approach to risk evaluation and management is not being employed consistently. Inadequate communication with the Environmental Management (EM) Programs increases the risk that ORNL construction projects may be located too close to a remediation project. Costs and potential health risks associated with construction are also 
increased at sites such as ORNL because the extent and magnitude of contaminant legacies are not fully known or documented.

Well-thought-out design basis documents, adequate for the intended purpose but without "overdesign," are not currently ensured. In some cases, this has led to high operating costs for inefficient facilities because life-cycle cost implications were not fully considered in design. Risks associated with use of high-risk design and construction contractors are discussed in Sect. 2.5.7.

ORNL organizations do not always consider the effects of their projects on others, and buildings are sometimes sited without adequate information regarding the plans for adjoining facilities. Finally, an effective configuration management system, including ensurance of accurate drawings and documents such as as-builts, is not currently available for either infrastructure or R\&D facilities (see Sect. 2.8). This situation increases overall project, and particularly ES\&H, risks when such facilities are later modified.

\subsection{PROJECT CLOSEOUT}

Currently, by the time of project closeout, insufficient funds frequently remain in projects to produce asbuilt drawings and to update the site atlas. Also, there is no individual or group at ORNL responsible and accountable for upgrading the ORNL atlas drawings and existing facility drawings and for utilizing configuration management for the infrastructure support area in a prioritized manner.

End users, project managers, and project sponsors interviewed by the Reengineering Team concerning recently completed ORNL ED\&C projects agreed that project drawings are generally either as-built or "redlined" after the project is completed. However, $100 \%$ of each group stated that the ORNL atlas and existing site drawings were not updated after their project was completed. The increased cost to followon projects is great, as site drawings become ever more inaccurate and each succeeding project must cope with developing supplemental information that should be available in the ORNL atlas or in existing site drawings before initiating project design.

From time to time over the past several years, some effort has been made to update the ORNL atlas and make site drawings more accurate, but funding and focus have never been adequate. It is clearly not feasible at this time to try to fund an all-out effort; however, improvements could begin through a continuing effort funded at a modest level with someone clearly responsible and accountable. A related problem is configuration control of high-priority aspects of the existing infrastructure. For example, if major power-line upgrades are made to meet the special needs of a program or facility, subsequent tieins to the upgraded power line need to be controlled to avoid power quality degradation and possible impacts on programs or facilities.

\subsection{FUNDING}

The current levels of funding are inadequate to address identified ORNL infrastructure and facility needs in a responsible way. A number of causes in combination have resulted in this situation, which, if remedied, could result in significant improvement of the condition of ORNL facilities over time. The largest gains are likely possible in more efficient use of funds through streamlined processes in implementing ED\&C activities (Sects. 2.4 and 2.5). 
Different types of projects are funded through different types of funds. In general, this restricts flexibility in dealing with capital issues and forces projects to be sized and implemented based on availability of a particular category of funds rather than on mission need. However, the Congressional action to merge GPP and general plant equipment (GPE) with the operating accounts has given considerable flexibility to capital funding that has not yet been fully implemented. It is now possible, in principle, to have a considerably larger portion of capital funds, both general purpose and program specific, for infrastructure and facilities upgrades. The trade-off is that these funds now come out of the programmatic operating funds and compete directly with programmatic funding for R\&D.

Aside from the potential increase in capital funding, possible flexibilities could offer enhanced efficiencies in budget execution. These include increased flexibility in the phase funding of GPP projects, the possibility of obtaining programmatic funds for GPP or GPE needs, and the increased capitalization level.

Numerous projects and infrastructure issues exist for which a funding source has not been identified. Unfunded infrastructure and facilities issues include orphan facilities, ES\&H deficiencies, reservation infrastructure issues, and energy-savings opportunities. Furthermore, when a decision between competing interests (program activities, ES\&H, infrastructure upgrade and repair, etc.) is made, infrastructure and facilities issues are often given a low priority.

There are a number of potentially viable sources of funds for infrastructure and facilities activities at ORNL beyond the traditional or currently used sources. These include program tax, space charge, program GPP, external funding, performance contracting, and possibly Landlord operating expense funding. Due to restrictions of federal law, a number of sources such as the Work-for-Others tax and property sales are not promising sources for generating excess funds to be used on facility upgrade or maintenance. Only the program GPP, performance contracting, and external funding represent net increases in capital funding for ORNL. The others represent exercise of flexibilities in the system to reallocate existing funds for infrastructure and facilities tasks.

Funds that arrive late in the funding year delay start of projects and result in poor costing performance or increased cost. In addition, projects that are phase funded have to schedule work effort based on the availability of funds rather than optimal project work planning. The difficulty is often compounded by not having the design or construction phases of a project ready to award when the funding arrives.

The overall budget process involves Congressional appropriation, Office of Management and Budget (OMB) allocation, and DOE distribution of funds to field sites. The DOE Headquarters (DOE-HQ) distribution to the field takes roughly 8 working days. The DOE-Oak Ridge distribution takes about 7 working days. The driving factor is that the EM portion of the budget must be approved by EM program managers prior to inclusion in the financial plan. This set of approvals generally takes about a week. Since the financial plan is a large document, it is DOE-Oak Ridge policy to do only one per month. The Energy Research portion could be distributed in a day if it were not constrained by the other program budgets. In special circumstances, DOE-Oak Ridge can make distribution in an interim financial plan in a shorter time frame. DOE-Oak Ridge has recently initiated electronic transfer of monthly financial plan changes, although the current plan is to use an e-mail transfer of the approved final financial plan only once a month. In principle, it would be possible to transfer the ORNL portion of the financial plan (minus EM) approximately a week earlier if DOE-Oak Ridge agreed to do multiple financial plan distributions per month. 
Currently, a significant amount of time often exists between arrival of funding and project start due to preaward activities that have not been completed. For projects going into construction, this could include completion of the certified-for-construction (CFC) process; construction readiness review; and bid package preparation, review, and approval before funding arrives. This up-front activity could potentially save 2 weeks or more in the overall process. If the job were put out for bid, another 2 weeks could be saved, although an award could not be made until funds were in hand.

\subsection{PERFORMANCE MEASURES}

Although LMES Central Engineering has used performance measurement for many years, improvements and modifications to this set of metrics are needed to develop the appropriate (i.e., critical few) parameters necessary for ECMD.

The most effective set of performance measures relates to customer satisfaction. By concentrating on the customer as the central focus for all activities, the most important measures of performance become evident: cost-effectiveness, adherence to schedule, safety, and overall quality of the product or service. By concentrating on these key components, several pitfalls of many performance measurement systems can be avoided. Most problems and failures occur when individuals or groups focus only on the process steps for which they are immediately responsible, rather than on the overall success of the project. Customer focus is more easily attained through a team-centered approach because each individual or group is made aware of interrelationships with other team members and how the team's success equates to customer satisfaction.

Benchmarking with DOE multiprogram laboratories indicated that none currently monitor their ED\&C processes in any formal way other than what is currently required by DOE in the Life-Cycle Asset Management (LCAM) order. These measures provide only a very generic glimpse of how their processes operate.

Contacts with other DOE laboratories, military organizations (e.g., U.S. Army Corps of Engineers), the National Aeronautics and Space Administration, and other organizations yielded little information on performance measures for ED\&C activities. Those contacted either did not currently measure such performance or had not completed development of their performance measurement programs. Formal performance measurement in the government is new, and apparently most organizations are in the midst of development.

Other sources of metrics include expected cost ranges for various project engineering components published by the R. S. Means Company and a set of "critical few" indices on cost, schedule, and safety developed by the Construction Industry Institute (see Appendix C.8 for details on these metrics and their potential applicability at ORNL).

An effective performance measurement system is an essential ingredient in any process improvement effort. Use of the measures and reference sources identified to develop a comprehensive set of performance metrics for ED\&C at ORNL, however, will be a difficult task because of the uniqueness of our situation and the numerous rules and constraints placed upon the conduct of our work. 


\section{CONCLUSIONS AND RECOMMENDATIONS}

\subsection{PRIMARY CONCLUSIONS}

The ED\&C Reengineering Team believes that a major overhaul of the current process is needed to eliminate inefficiencies, lower costs, increase customer control, provide flexibility, and increase performance in support of ORNL missions. Since 1990, construction costs have dramatically increased by approximately $40 \%$. The use of a construction manager accounts for 20 to $30 \%$ of the cost increase (depending on the size of the project), with the remaining 10 to $20 \%$ of the cost increase divided between increased ES\&H requirements and use of a PLA.

If the team's recommendations are fully implemented, a reduction of 25 to $40 \%$ in costs of ED\&C projects appears to be achievable, with an initial investment of about $\$ 0.5$ million. A major benefit is that ORNL will be able to compete successfully for a greater percentage of Landlord funds and should experience a one-third increase in useful construction for a given capital expenditure. Sixty percent of the cost reduction should accrue within months, and the remainder, within 2 to 3 years as the new ED\&C process matures. An overall reduction of 3.3 FTEs involved in ED\&C activities is expected. However, because of recommended changes to the ED\&C process, ORNL will actually gain 6 FTEs (through reassignment of current staff), mainly to support construction activities (Table 6). The underlying rationale for these cost savings is provided in Sect. 5 .

Table 6. Projected changes in numbers and affiliation of FTEs from reengineering $\mathrm{ED \& C}$ activities ${ }^{a}$

\begin{tabular}{|c|c|c|c|c|}
\hline \multirow{3}{*}{ Activity } & \multicolumn{4}{|c|}{ Organizational affiliation of FTEs } \\
\hline & \multicolumn{2}{|c|}{ Current } & \multicolumn{2}{|c|}{ Reengineered } \\
\hline & MK-F & ORNL & MK-F & ORNL \\
\hline Design & - & 0.9 & - & 1.5 \\
\hline Construction & 9.3 & 7.6 & - & -13.0 \\
\hline Total & \multicolumn{2}{|c|}{17.8} & - & 14.5 \\
\hline
\end{tabular}

${ }^{a}$ Approximate annual cost savings of \$400K for FY 1998-FY 1999 ORNL ED\&C projects. $\mathrm{FTE}=$ full-time equivalent; $\mathrm{ED} \& \mathrm{C}=$ engineering design and construction.

${ }^{b} \mathrm{MK}-\mathrm{F}=\mathrm{MK}-$ Ferguson.

\subsection{RECOMMENDATIONS}

The team has formulated recommendations for changes in the current ED\&C process that are thought to be key to successful implementation of a revised approach. These recommendations cover the following 14 topical areas:

1. Construction Manager,

2. Project Labor Agreement, 
3. Roles and Responsibilities,

4. Flexibility and Innovation in Contracting,

5. Contractor Qualifications,

6. Contractor Accountability,

7. ES\&H Oversight,

8. Davis-Bacon Act Compliance,

9. Performance Measures,

10. Cost Distribution,

11. Infrastructure Configuration Management,

12. Risk Management,

13. Funding Delays and Limitations, and

14. Infrastructure Support Planning.

The recommendations and supporting rationale are as follows. The rationale was detailed in the review of the current situation presented in Sect. 2.

\subsubsection{Recommendation 1: Construction Manager}

- ORNL should not utilize a general construction manager; however, large complex projects should be evaluated on a case-by-case basis to determine whether use of a construction manager is warranted.

\section{Rationale}

- Use of a construction manager adds $20-30 \%$ to construction costs, depending on project size.

- Construction managers are not used by other Energy Research national laboratories (ANL, BNL, LBNL, and the privatized part of PNNL), LLNL, or NREL.

- Use of a construction manager places ORNL in a noncompetitive position relative to other Energy Research national laboratories.

- Fifty percent of the local construction contractors surveyed feel that use of a construction manager is a moderate-to-critical problem.

- A number of very highly regarded local construction contractors will not bid on work through the existing construction manager.

- The present negative synergism of obtaining construction contractors through a third party is not only inefficient but also results in constructors focusing on the needs of the construction manager, rather than those of the end user.

\subsubsection{Recommendation 2: Project Labor Agreement (PLA)}

- ORNL should not enter into a general PLA. Each construction contractor should be required to develop a project-specific PLA mutually beneficial to ORNL and the contractor.

- It would be the contractor's responsibility to reach a workable relationship with regional construction trade unions. Any strike-related delays would be the contractor's responsibility. 


\section{Rationale}

- The current general PLA between MK-Ferguson and the KBCTC adds 10-20\% to the cost of construction projects at ORNL.

- The current PLA restricts MK-Ferguson to four people of its choice; all others are selected by the union business agents that comprise the KBCTC. This provision, combined with restrictive KBCTC work rules, results in increased cost.

- Highly desirable contractors do not bid on ORNL work, in part because of the PLA.

- A PLA is not used by other Energy Research national laboratories (ANL, BNL, LBNL, or the privatized part of PNNL), LLNL, or NREL.

- The majority of contractors surveyed believe the following:

- The PLA is not essential for labor peace (64\%).

- The union work-rule provisions of the PLA result in inefficiencies (60\%).

- Eliminating the threat of strikes or lockouts is not worth the added cost (55\%).

\subsubsection{Recommendation 3: Roles and Responsibilities}

- R\&D division directors and the Infrastructure Program Manager should be responsible and accountable for programmatic- and Landlord-funded ED\&C projects, respectively, with particular emphasis on the following:

- budget and cost control;

- project manager selection;

- project planning and execution;

- ensuring ES\&H planning and surveillance;

- quality assurance;

- integration of responsibility and accountability of ORNL facility managers into project implementation;

- mitigation of collateral impacts;

— graded approach for design standards and configuration management ;

- project completion, including as-builts and maintenance/operating information; and

- ensuring that ORNL ED\&C processes are followed consistently. 


\section{Rationale}

- Greater formality is needed in roles, responsibilities, authority, and accountability for R\&D division directors, the Infrastructure Program Manager, ORNL project managers, and other participants.

\subsubsection{Recommendation 4: Flexibility and Innovation in Contracting}

- $\quad R \& D$ divisions and the Infrastructure Program Manager should have direct access to ED\&C contractors and support personnel through a number of options based on flexible, innovative contracting practices facilitated or managed by the ORNL ECMD.

\section{Rationale}

- Effective approaches can be tailored to meet the diverse needs of ORNL ED\&C projects.

- End users can select among multiple options for obtaining ED\&C services.

- Specifications can be stated in the straightforward, commercial-type language with which contractors are familiar; DOE orders and procedures should not be emphasized.

- Forty-two percent of end users are dissatisfied with past design services.

- Forty-seven percent of project managers/engineers believe they were not involved or were only slightly involved in the selection of the design organization.

\subsubsection{Recommendation 5: Contractor Qualifications}

- ORNL should select and award contracts only to highly qualified ED\&C firms that have demonstrated commitment to end-user satisfaction, project performance, worker safety, and environmental compliance.

\section{Rationale}

- ANL, LBNL, LLNL, and NREL use the safety record of the construction contractor in evaluating acceptability of contract bids.

- $\quad$ ANL, LBNL, BNL, and NREL use prequalified design contractors.

- LBNL, BNL, LLNL, and NREL use prequalified construction contractors.

- The Brooks Act requires that the A/E selection process be done via prequalification for engineering services for government contracts.

- Design contractors are currently selected for ORNL projects with little or no end-user input.

- The construction manager selects the construction contractor for ORNL projects with little or no enduser input. 


\subsubsection{Recommendation 6: Contractor Accountability}

- Construction contractors should be held accountable for ensuring that work is executed in accordance with applicable codes and standards, including ORNL Necessary and Sufficient Standards, and should be held accountable for all activities occurring on their construction site, including safety and environmental compliance.

\section{Rationale}

- The University of Tennessee and NREL hold construction contractors responsible for safety and environmental compliance.

- Commercial contracting practices place quality assurance of construction under the purview of the contractor.

- Success of recent Environmental Management Program Integrating Contractor (EPIC) projects was due in part to use of commercial contract requirements that specified applicable codes and standards.

- The construction contractor can manage safety and environmental compliance efficiently without impacting the project.

\subsubsection{Recommendation 7: ES\&H Oversight}

- ORNL ES\&H oversight of construction and construction-like activities should be conducted by only one ORNL overhead-funded organization under the direction of the ORNL project manager, who should resolve all recommended actions except those involving imminent danger.

- Independent ES\&H oversight staff will report in a line manner to the ES\&H support organizations. Oversight staff who do not concur with the project manager's resolution of their recommendation can pursue it through their line management.

- Staff for ES\&H planning and surveillance will be part of the project team, reporting to the project manager.

\section{Rationale}

- Many ORNL organizations provide ES\&H oversight in a duplicative, uncoordinated fashion (Table 4).

- The survey evoked strong negative responses about current ES\&H oversight (Table 5).

- The need exists to

- maintain an appropriate level of independent oversight while eliminating duplication,

- ensure proper balance between project implementation and ES\&H oversight, and

- clarify lines of authority and responsibility and enhance system efficiency. 
- The R\&D division director or the Infrastructure Program Manager must provide leadership to ensure proper integration of ES\&H activities into project planning and implementation.

\subsubsection{Recommendation 8: Davis-Bacon Act Compliance}

- The ORNL Davis-Bacon review process should be streamlined. Consideration will be given to these actions.

- Change focus to determining whether construction crafts (Davis-Bacon wage rate) or in-house maintenance crafts are required, rather than determining the implementing organization and the method of accomplishment.

- Utilize a Web-based system for acquiring and disseminating project information as well as the resulting determination on utilization of maintenance or construction labor.

- Move this function organizationally from P\&E to the ORNL ECMD.

- Eliminate three-site Labor Standards (Davis-Bacon) committee participation.

\section{Rationale}

- Web-based system would shorten time required to obtain ruling.

- Present review process is time-consuming because of the inefficient construction process available to ORNL.

- Improvements in the ED\&C approach will eliminate present impacts of Davis-Bacon determinations.

- Moving function to ORNL ECMD will significantly decrease any perceived or actual conflict of interest with ruling.

\subsubsection{Recommendation 9: Performance Measures}

- ORNL ECMD should develop a set of performance measures that is responsive to the needs of ORNL end users and the DOE/ORNL Site Office and can be applied in a graded approach to specific projects by project managers.

- Consider current Life Cycle Asset Management (LCAM) metrics established with the DOE/ORNL Site Office.

- Use R. S. Means estimating guides and Construction Industry Institute metrics for comparison.

- Extensive historic performance data are available and should be considered.

\section{Rationale}

- There are quantitative means for management to assess the delivery of products and services to the customer and form the basis for making intelligent decisions. If properly selected, they are a key tool in helping us understand, manage, and improve the performance of our ED\&C organizations. 


\subsubsection{Recommendation 10: Cost Distribution}

- The method used to collect and distribute costs for ORNL ED\&C activities, including administering design and construction contracts, should reflect actual costs to the users of ED\&C services.

- Distribute primary cost elements directly to final cost objectives.

- Distribute burden for ED\&C services based on the primary cost elements associated with burden.

\section{Rationale}

- This approach is consistent with ongoing discussions within the ORNL Delta Project.

- It is easier to understand and explain the cost of ED\&C services by pooling cost components for administering such services.

\subsubsection{Recommendation 11: Infrastructure Configuration Management}

- The ORNL Infrastructure Program Manager should be responsible and accountable for determining how to upgrade the ORNL atlas drawings and existing facility drawings and for utilizing configuration management for the infrastructure support area in a prioritized manner.

\section{Rationale}

- End users, project managers, and project sponsors interviewed for recently completed ORNL ED\&C projects agreed that the project drawings are generally either as-built or "redlined" after the project is completed. However, $100 \%$ of each group stated that the ORNL atlas and existing site drawings were not as-built after their project was completed.

- Seventy-eight percent of the project managers and design engineers interviewed concerning recently completed ORNL projects stated that no organization is funded to provide, or is responsible for providing, as-built ORNL site drawings.

- The verification of utility locations for each project because of inadequate drawings increases project cost.

\subsubsection{Recommendation 12: Risk Management}

- A more formal Risk Management Program covering ED\&C activities should be implemented within the ORNL ECMD.

- Identify areas of moderate or high risk, discuss approaches for mitigating risks, and achieve proper balance between cost for a given project risk and the risk mitigation cost.

- Provide R\&D division director or Infrastructure Program Manager a basis for informed application of a graded approach to management of risks.

- Use risk assessment techniques such as the Capital Assets Management Program (CAMP), the ES\&H risk matrix, and business risk. 


\section{Rationale}

- ES\&H risks must be considered on any construction project. Questions related to responsibility, oversight, level of acceptable risk, and training requirements must be addressed.

- The number of EM projects on the ORNL site is increasing, and contamination legacies exist throughout the site.

- Conflicts between projects (existing and planned) must be accounted for.

- Adequacy of design, including life-cycle costs, must be ensured in developing Design Basis Documents.

- High-risk contractors require more surveillance and make it more likely that retrofitting will be necessary.

\subsubsection{Recommendation 13: Funding Delays and Limitations}

- ORNL and DOE-Oak Ridge should minimize delays in implementation of ED\&C projects.

- Create a separate Web-based financial plan with weekly update.

- Ensure that projects can be implemented immediately when funds become available.

- Explore approaches for increasing flexibility for use of different funding categories.

- Expand use of programmatic GPP funding.

- Explore alternate funding sources for critical infrastructure and program issues.

\section{Rationale}

- Funds that arrive late in the funding year delay the start of projects and result in poor costing performance or increased cost.

- Work for phase-funded projects must be scheduled based on availability of funds rather than on optimal work planning.

- Different types of projects are funded from different sources. This restricts flexibility and forces projects to be sized and implemented based on limited availability of a particular category of funds, rather than on optimal support for mission needs.

- Numerous infrastructure and facilities issues (orphan facilities, ES\&H deficiencies, reservation infrastructure needs, energy-savings opportunities) have no identified funding source. Alternate methods of funding need to be found.

- Infrastructure and facilities issues often assume a low priority when a decision is made among competing interests (program activities, ES\&H, infrastructure upgrade and repair, etc.). 


\subsubsection{Recommendation 14: Infrastructure Support Planning}

- ORNL should integrate the processes for planning and justifying infrastructure projects and ORNL programmatic strategic planning.

\section{Rationale}

- A consistent approach for planning, prioritization, and tracking of high-priority infrastructure needs is required.

- Program managers do not proactively share information on proposed projects with the Infrastructure Program Manager.

- In a time of shrinking budgets, there is pressure to absorb infrastructure maintenance costs through overhead or by postponing needed projects.

- The end result is the continuing deterioration of ORNL facilities and a process that lacks the information needed to achieve a proper balance between $R \& D$ and infrastructure maintenance.

- Absorbing infrastructure maintenance costs in overhead is counter to the current general direction to reduce ORNL overhead.

- The need exists to ensure that limited infrastructure program resources are used in a manner consistent with priorities of present and emerging ORNL programmatic requirements.

- Of the end users, program sponsors, and project managers interviewed concerning recently completed ORNL ED\&C projects, $100 \%$ stated that they were not involved in the ORNL infrastructure prioritization process for selecting needed upgrade projects.

- Fifty percent of the project managers, $67 \%$ of the project sponsors, and $100 \%$ of the end users were not even aware that a prioritization process exists.

\subsection{GUIDING PRINCIPLES FOR IMPLEMENTING RECOMMENDATIONS}

A set of 11 principles was synthesized from the 14 recommendations to guide development of the new approach to ED\&C proposed in Sect. 4 of this report.

- Only proven, highly qualified, experienced, and competent firms with good safety records will be selected to perform engineering and construction work.

- These firms will be held responsible for the performance of their contracted work, including safety and environmental compliance.

- ORNL will provide a positive and desirable environment in which these firms can work efficiently.

- $\quad \mathrm{R} \& D$ organizations will have multiple choices for ED\&C service providers. 
- ORNL engineering and construction practices will be comparable to, and competitive with, the best practices of other Energy Research national laboratories.

- The ORNL ECMD will operate in a flexible, high-value-added manner to support the ORNL R\&D missions and infrastructure needs.

- ED\&C practices will be applied consistently in a graded manner to match the requirements of a given project.

- Independent ES\&H oversight actions associated with ED\&C activities will be conducted by only one ORNL overhead organization. All recommended ES\&H actions, except those involving imminent danger, will be resolved by the ORNL project manager.

- Handoffs between organizations will be minimized as much as possible consistent with project size and risk.

- End-user involvement is essential for project success. Project teams will include representation from all affected organizations, and communication between organizations will be maximized.

- Flexible, innovative, cost-effective contracting approaches will be pursued aggressively and utilized fully. 


\section{DESCRIPTION OF NEW APPROACH}

\subsection{PHILOSOPHY}

In any business activity, optimum performances-coupled with top-notch quality and matched with maximum return on investment-are goals of a successful operation. At ORNL this is no exception. The process of competing with other DOE laboratories for programs is no different than commercial enterprises competing for business. Effective and efficient infrastructure and operational support of programs are essential aspects of maintaining a competitive edge among DOE Energy Research laboratories. The ED\&C support needed for ORNL should be patterned after the best industry practices at minimal cost in order to be responsive to the R\&D mission. Ideally, the ORNL ED\&C functions will emulate the best regional services and, in fact, should be the model for both commercial and governmental organizations of similar size (i.e., ORNL ED\&C support should be labeled "best in class" for DOE Energy Research laboratories). A reengineered ED\&C process will not only enhance ORNL's competitiveness but will also accomplish this through much more efficient use of the resources provided by the U.S. taxpayer through Congressional appropriations for ED\&C.

Changes in the way ED\&C is accomplished at ORNL are intended to yield a more division-focused approach. Line organizations will have more control over how construction is performed and designs are undertaken. R\&D division directors and the Infrastructure Program Manager will be responsible and accountable for programmatic- and Landlord-funded ED\&C projects with particular emphasis on (1) controlling budget and costs; (2) selecting the project manager, (3) planning and executing projects; (4) ensuring that ES\&H planning and surveillance are in place, (5) integrating responsibility and accountability of ORNL facility managers into project implementation, (6) mitigating collateral impacts, (7) utilizing a graded approach for design standards and configuration management, and (8) ensuring that project completion includes as-builts and maintenance/operating documentation. $\mathrm{R} \& \mathrm{D}$ division directors and the Infrastructure Program Manager will have direct access to ED\&C contractors and support personnel through a number of options based on flexible, innovative contracting practices facilitated and managed by the ORNL ECMD.

Figure 3 compares the current ED\&C approach with the proposed approach. The proposed approach streamlines the organizational interfaces and minimizes project information handoffs, permitting improved up-front planning in the predesign and design stages and thus minimizing costly changes during the construction phase. Increased flexibility in obtaining ED\&C services (Fig. 4) is intended to create cost-saving opportunities as well as bring the end provider (designer/constructor) closer to the end user (R\&D division director/Infrastructure Program Manager).

\subsection{DAVIS-BACON DETERMINATIONS}

The Davis-Bacon Act ruling process is seen by many end users to be burdensome; time-consuming; and, in some ways, related to ED\&C problems at ORNL. The Reengineering Team has concluded, however, that the Davis-Bacon ruling process is not the problem; rather, the required use of a general construction manager creates undue cost and schedule restrictions that make construction costs for small projects prohibitive. 


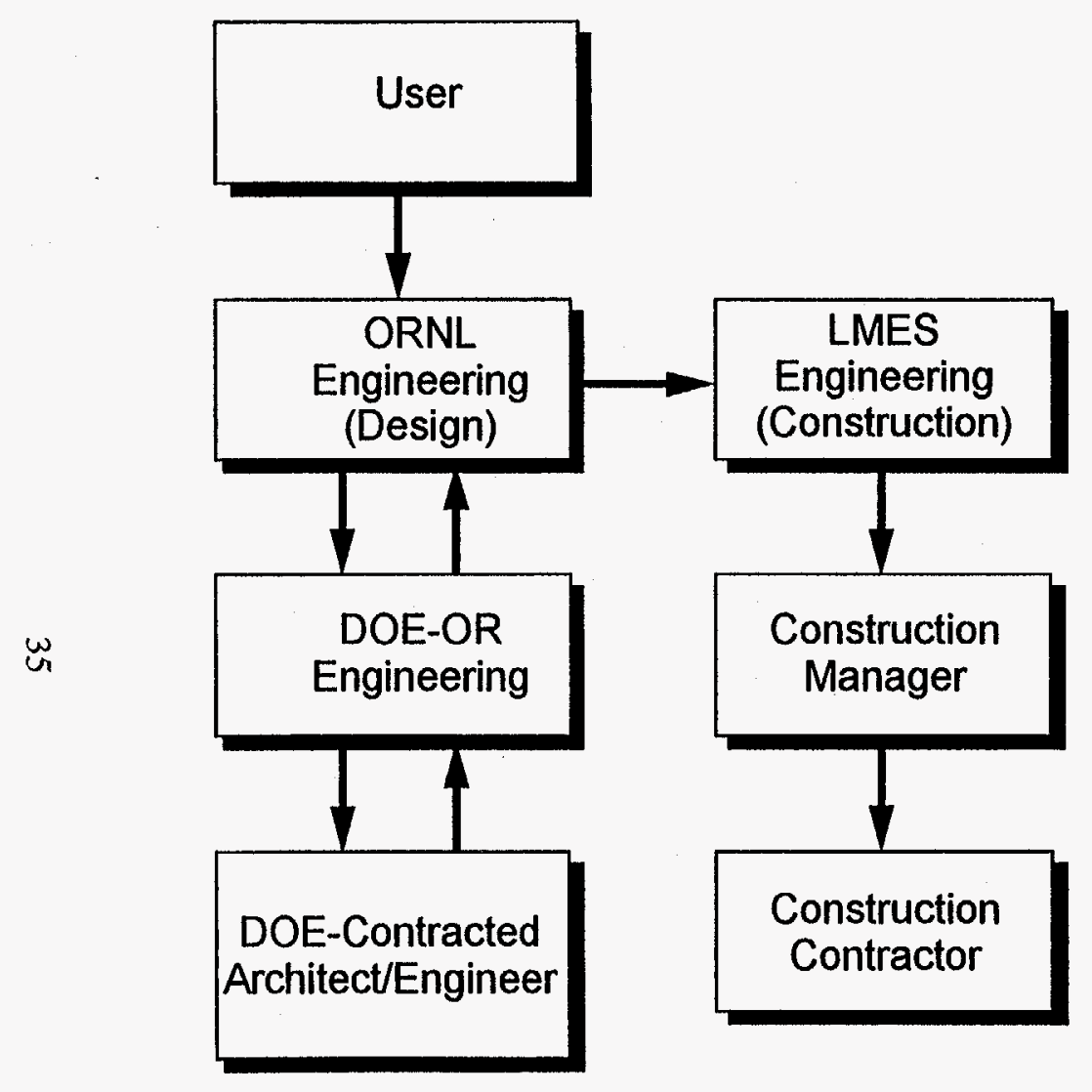

Current

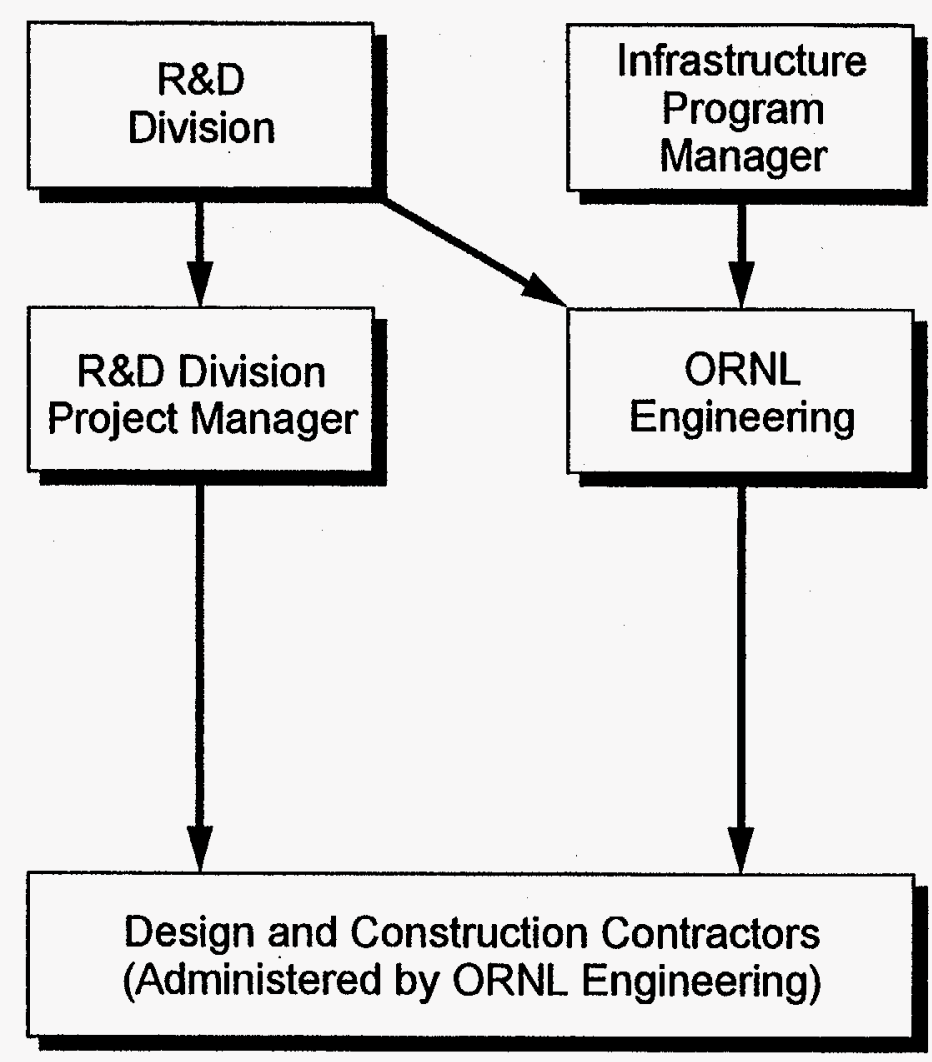

Proposed

Fig. 3. Comparison of the current engineering design and construction approach with the proposed approach. 


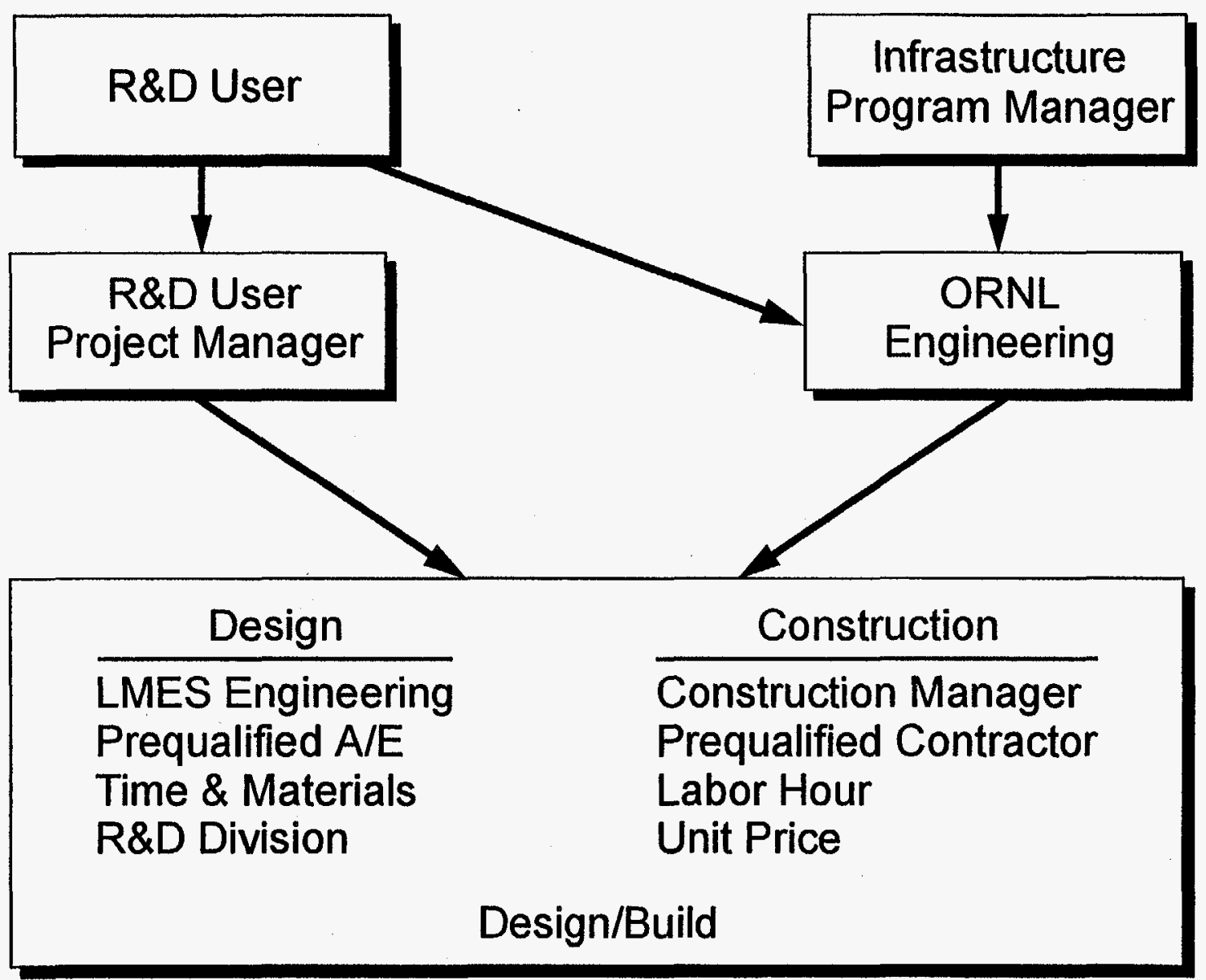

A/E - Architect/Engineer

Fig. 4. Use of a diverse set of design and construction contractors to increase flexibility. 
Changes to the Davis-Bacon processes will include transferring the ORNL Site Labor Standards Committee management from P\&E to ECMD. It was concluded that ECMD would be a more independent group to manage this function. $P \& E$ is instrumental in carrying out work that is reviewed through the Davis-Bacon process and therefore has a vested interest in the outcome of such reviews. Although ECMD performs no Davis-Bacon work, it is knowledgeable of its requirements and manages projects that fall under the Davis-Bacon Act, the Service Contract Act, and pure maintenance rulings.

The determination process will continue as described in LMES procedure MA-101, Application of Federal Labor Standards, and in the training manual for the LMES course, Application of Federal Labor Standards. In the recent past, ORNL has participated in a three-site Labor Standards Review Committee. This committee coordinated Lockheed Martin determinations across all three sites prior to forwarding determination requests to the DOE-ORO Labor Standards Committee. With changing site missions and changes in DOE prime contractors, ORNL should no longer participate in the three-site committee; consequently, this committee is not shown in the flowcharted process in LMES procedure MA-101, Application of Federal Labor Standards, and in the training manual for Application of Federal Labor Standards. Efforts will be made to focus determinations on whether Davis-Bacon wage rates are required, rather than on determining which organization or method of accomplishment will be utilized. Final authority for the determination remains with the DOE Labor Standards Committee. Labor standards rulings will continue to be posted in a reading room for review by the ATLC and the KBCTC labor unions.

The current system based on paper forms will be evaluated to determine if a Web-based system for acquiring and disseminating project information and the resulting determinations would be more efficient. A Web-based system could make routine determinations in real time rather than via weekly scheduled determinations. With further DOE acceptance, all determinations could become real-time. Changing to such a system could reduce the time required to obtain determinations. Another consideration for streamlining the determination process is the implementation of blanket determinations. Blanket determinations would be proposed for categories of routine work that are accomplished on a frequent basis. Once determinations are made for a given type of work, the same ruling would be applied to other work in that category without going through the formal evaluation process. Application of blanket determinations will reduce the time and cost of accomplishing work.

Work ruled to be covered by the Davis-Bacon Act is considered construction work and cannot be performed by P\&E crafts because of restrictions in the LMER contract limiting LMER to maintenance

work. Recommendations on changing the LMER contract to permit ORNL staff to perform construction have been made in the P\&E Division Research Support Services Process Reengineering Team report, dated September 1996.

\subsection{CONTRACTING}

Contracting approaches for engineering design services and construction are a major driver in the performance of projects at ORNL. Currently, both engineering design services and construction are provided through contracts held by organizations other than ORNL. In the future, ORNL should select and award contracts directly for both engineering design services and construction (Fig. 4). This approach is consistent with that used by other Energy Research laboratories and provides the best opportunities for cost and schedule efficiencies. 
For this to become a reality, ORNL must create DOE confidence in its ability to manage and direct this contracting activity. Since there are various opinions as to whether this function is currently authorized in the LMER contract, clarification of contract terms needs to be formalized prior to initiating any contracts of this nature.

ORNL will utilize existing staff within ECMD and the Contracting/Procurement Division to perform these functions. Processes and procedures will be developed or modified to cover this new contracting activity for ORNL. It is intended that ORNL select and award contracts only to highly qualified ED\&C firms that have demonstrated commitment to end-user satisfaction, project performance, worker safety, and environmental compliance. These contractors should be held accountable for meeting applicable codes and standards (specified from ORNL Necessary and Sufficient Standards) and for all activities at their work site.

Innovative, cost-effective contracting procedures/methods will be used to procure engineering design services and construction. These procedures and methods include prequalifying contractors under taskorder agreements, using labor-hour contracts for building trade support for some small projects, and contracting for design and construction function simultaneously when advantageous (Fig. 4). Utilizing design/build approaches or teaming designers with constructors can yield improved final products at lower cost and in a shorter time frame.

\subsection{PLANNING}

Effective planning and communication are critical to the successful performance of ED\&C. Lack of planning and ineffective communication are the cause of project delays and are significant contributors to cost overruns. Effective planning establishes the roles and responsibilities necessary for effective communications. With the responsibility to manage $\mathrm{ED} \& \mathrm{C}$ projects being spread across line organizations, a consistent approach to planning and executing projects is needed. The Project Delivery system developed by $\mathrm{CH} 2 \mathrm{M}$ Hill and Work Systems Associates, Inc., is an approach that is considered to meet the needs of ORNL. The Project Delivery system is a client-focused application of basic project management principles. The main principles include utilization of the project manager as a leader and primary decision-maker, a focus on client satisfaction, and consistent project planning and execution.

The Project Delivery system is summarized as follows from CH2M Hill's report entitled Project Delivery, A System and Process for Benchmark Performance:

\section{Chartering of the project team by management}

Project manager as leader-A project manager who can both lead and manage and who is trained in the application of the project delivery process will deliver successful projects. The project manager's primary responsibility is to ensure that projects achieve client satisfaction and sound financial performance.

Client satisfaction and strong relationships-Every aspect of project delivery should be driven by a clear focus on client satisfaction. Viewing the client as an integral part of the project, rather than as an outsider, requires developing robust relationships with the client at the outset and maintaining these relationships throughout the project. 
Consistent project planning and execution-The application of clearly defined planning and execution processes, including the following, is the primary means to improving project performance.

Project planning-Building, chartering, and sustaining the project team: Selecting the best members for the team has always been important. Now project managers can use team-chartering techniques to create the team synergy that adds value to the project.

Developing a clear, complete project workplan-A well-crafted and consistently implemented workplan leads to successful project delivery. Workplans define the project, detail the work breakdown structure, and describe the roles and responsibilities of the project team.

Endorsing the project-Endorsement of the charter and workplan by the entire team, including the client, represents a higher level of commitment and validation than the traditional procedure of approving a project workplan.

Project execution-Managing change: All projects experience change. Controlling change during a project marks the difference between average performance and benchmark performance.

Closing the project-Planning for project closure at the beginning of the project and implementing closure activities throughout the project will lead to improved project performance.

All of these elements are part of the process that the ED\&C Reengineering Team independently identified as essential for successful project completion at ORNL. It is intended that future projects at ORNL will be managed using this Project Delivery system.

A key focus point the Reengineering Team addressed was the role and responsibility of the project manager. For future projects at ORNL, project managers need to be selected based upon their competencies for the task. In some cases, the project manager will be from the line division sponsoring the project. In other cases, this individual will be from the Project Management group within ECMD. Sponsoring divisions need to select the project manager based upon the needs of the project and the capabilities and experience of available personnel.

The Construction Industry Institute (CII) has developed an Owner/Contractor Work Structure Process Handbook (CII Implementation Resource 11-2, April 1997), which describes a process for determining effective work structures between owners and contractors. This process is analogous to line divisions working with the ECMD to develop project plans and determine work team structures, including evaluations of competencies for filling strategic roles such as the project manager. The CII process is systematic and structured and can therefore be applied to a variety of organizational situations. This process can be utilized to identify the best team composition for various projects.

Once a project manager is selected and the best-suited project team is formed, planning activities will begin. Team members will be from the end-user organization, the ES\&H organization, and technical lead organizations. If necessary, personnel from both the $\mathrm{A} / \mathrm{E}$ design firm and the construction contractor may be brought onto the team. Project planning activities will continue to follow the guidance provided in DOE Order 430.1, Life-Cycle Asset Management (LCAM), and the Joint Program Office Direction on Project Management (January 1996) as required by the level of project funding. 


\subsection{DESIGN}

Designing a project is formulating into documents such as drawings, plans, and specifications those concepts and ideas developed in the planning stage. A key focus of the new process is the involvement of the end user. Inclusion of the end users in the planning stage as members of the project team should ensure incorporation of their input into the design of the project. The adequacy of the design, without the possibility of overdesign, must be considered during the planning and review stages of the project. The project team must ensure that a well-thought-out design basis document is produced. The scope of the project must be correctly assessed to ensure that the completed facility or modification will be adequate for use and suited for future expansion/flexibility. Design considerations have to be made for compliance with regulatory concerns, health and safety of workers, and long-term risks associated with the operation of the facility.

The majority of projects will be designed using the services of one of several $\mathrm{A} / \mathrm{E}$ firms contracted directly by ORNL. Contracting directly will strengthen the relationship between the designer and the end user/operator. Only small maintenance or construction-type projects will be designed in-house and only when such practice is determined to be cost-effective or efficient because of the knowledge held by in-house engineers. These design contracts will be maintained and managed by the ECMD and will be the vehicle through which research divisions obtain engineering design support services. In addition, the R\&D divisions will use in-house design capabilities as necessary to complete specialty design work and small maintenance activities.

The project manager will lead the team through the design process. Assisting the project manager will be a lead technical person, normally referred to as the principal engineer. The principal engineer will be the lead coordinator for the technical aspects of the design, including resolution of design criteria, arrangements for design reviews, and acceptance of the final design documents. With a smaller design staff at ORNL, more reliance will be placed upon the A/E firms for their expertise and capabilities. ORNL does not intend to redesign projects due to poor quality designs from inexperienced or poorly managed $\mathrm{A} / \mathrm{E}$ firms.

Several different design contracts will be placed with $A / E$ firms. Since ECMD has only a small design staff, some task-order-type $\mathrm{A} / \mathrm{E}$ design and engineering services contracts will be in place to augment short-term ad hoc design requirements. These contracts will not be for a specific individual task but, rather, will establish rates for various disciplines and services that can be then contracted for through small-tasking agreements. For larger specific projects, individual contracts will be awarded that will provide for the traditional Title I, II, and III types of services.

Standardized design contract documents will be used for specifying design requirements. These documents, such as those recommended by the American Institute of Architects (AIA), are used widely throughout industry to define and communicate requirements to designers. Utilizing such methods will increase competition for design services, reduce the cost of producing voluminous design specifications, and improve the communication between ORNL and the AVE firm. Other improvements sought in the $\mathrm{A} / \mathrm{E}$ design process will be to tailor the design reviews, submittals, design documents/reports, and calculations to the needs of the project. Qualifications and capabilities will be the primary factors in selection. Improvements in designs and contracting methods will be sought from the A/E firms. Their commercial practices and experiences will be considered to assist ORNL in sharpening its competitive edge. 


\subsection{CONSTRUCTION}

ORNL intends to manage all non-Environmental Management and Enrichment Facilities (EMEF)-construction conducted at the Laboratory by adapting the best practices used by DOE's other Energy Research laboratories and also to institute a number of flexible, innovative contracting practices that will be available to ORNL's research divisions. Acquisition methods will include (1) traditional firm fixed-price contracts for well-defined scopes of work; (2) unit-priced contracts for routine requirements such as paving, concrete curbing, sidewalks, and minor renovations; (3) design-build contracts, where integration of the design and construction will be cost-effective and efficient; (4) engineer-procureconstruct arrangements where the designer is best suited to integrate the design and the construction; and (5), possibly, basic order agreement contracts for general and specific labor requirements. Highly qualified construction firms that have demonstrated commitment to customer satisfaction, project performance, and worker safety will be selected to perform construction at ORNL. These firms will be held responsible for the performance of their contracted work, including safety, while ORNL will provide a positive, desirable, and effective environment for the firms to accomplish work. Management of construction subcontracts will be accomplished by the ORNL ECMD, rather than through a general construction manager. (The latter practice currently adds up to $30 \%$ to costs for most construction projects.) In-house staff with experience and training in construction management will be used for managing construction contractors for small- and medium-size projects, augmented with subcontract personnel on a case-by-case basis. For a large project, such as the Spallation Neutron Source, the services of a construction manager will be utilized if warranted.

The plans and specifications, including terms and general conditions, for construction contracts will be specific to the requirements of the work. The intent will be to use standard commercial contracting practices that are familiar to the majority of the firms with which ORNL chooses to perform construction. The plans and specifications should apply industrial and commercially accepted codes and standards and be in keeping with the Necessary and Sufficient standards being developed for ORNL.

Construction support currently provided by the general construction manager will be provided by ORNL organizations. Those organizations may choose to use in-house staff and/or subcontract personnel. Examples of needed support include badging, training, ES\&H oversight, health physics coverage, occurrence reporting, accounts payable, waste management, and subcontract administration.

It is anticipated that very little non-EMEF direct-hire work will be necessary. Several options exist for the accomplishment of such work. One option is a labor contract awarded through competitive bidding, as is done by other Energy Research laboratories. Task orders would then be issued for specific tasks. Use of a task-agreement contract will depend on the projected construction volume. A second option is to use the contractor performing direct-hire work at the Y-12 Plant, assuming that the Y-12 facility has a contract for those construction services.

ORNL's goal is to accomplish construction in the most cost-effective manner, giving the Laboratory the most for its funds. All construction work at ORNL is currently performed in accordance with a PLA between MK-Ferguson of Oak Ridge and the KBCTC. Work under this agreement historically adds 15 to $25 \%$ to the cost of construction. This added cost results from a number of factors which include (1) higher bids by construction companies due to the uncertainty of the union-provided labor force;

(2) higher union wages than are required by the Davis-Bacon Act; (3) loss of competition resulting from the number of highly regarded and competent contractors who choose not to bid on ORNL projects due to the PLA; (4) inefficiencies of construction caused by the normal restrictive jurisdictional work rules; 
and (5) increased claims against projects due to the lack of control over the contractor's work force and the inherent liability accrued to the government by requiring contractors to utilize the PLA.

ORNL desires to adhere to the policy concerning PLAs outlined in President Clinton's Executive Memorandum dated June 5, 1997.

Executive departments or agencies during this Administration authorized to award a contract for the construction of a facility to be owned by a Federal department or agency may, on a project-by-project basis use a project labor agreement on a large and significant project ("large and significant" is defined in Section 6(d) as "a Federal construction project with a total cost to the Federal Government of more than $\$ 5$ million"\}, (a) where a project labor agreement will advance the Government's procurement interest in cost, efficiency, and quality and in promoting labor-management stability as well as compliance with applicable legal requirements governing safety and health, equal employment opportunity, labor and employment standards, and other matters, and (b) where no laws applicable to the specific construction project precludes [sic] the use of the proposed project labor agreement.

Making projects costing less than $\$ 5$ million adhere to the requirements of a PLA reduces the effectiveness of the construction dollars coming to ORNL. Furthermore, the Laboratory desires that any PLA imposed for construction at the ORNL site give a contractor the latitude to provide at least $50 \%$ of the work force from its own personnel. Also, any PLA established should be effective for a period of time not to exceed 3 years.

\subsection{ES\&H OVERSIGHT AND PROJECT SUPPORT}

Bringing a balance to ES\&H requirements in design, construction, and construction oversight is imperative to reducing construction costs at ORNL. As previously discussed, over the past several years there has been a dramatic increase in attention to the areas of ES\&H. It is the intent of the Reengineering Team to ensure that ES\&H remains a focused area for construction at ORNL to ensure the safety and health of construction workers and the general Laboratory population, as well as to protect the environment. Controlling the number of individual ES\&H groups that have overlapping responsibility/authority will be key to reducing construction interruptions and differing interpretations of rules for construction.

The Reengineering Team recognizes the following three separate ES\&H functions that will be associated with a given project:

1. Examination of hazards and risks inherent in the project-after project definition is sufficient to allow this determination. This examination will alert the ORNL independent oversight function to the hazards and risks for which independent ES\&H oversight will be implemented. It will also provide the means for communication and general consensus to be reached between the independent oversight function and the project manager on the hazards and risks inherent in the project.

2. Provision of independent ES\&H oversight during project implementation, with primary emphasis on independent oversight of construction activities.

3. Provision of ES\&H support to the project manager as an integral part of project formulation, planning, surveillance, and implementation. 
The first two functions will be provided by a SHEST-like organization. The third will be the responsibility of the project manager, who will include ES\&H personnel on the project team or obtain ES\&H support for the project as necessary, based on the project manager's assessment of hazards and risks present in execution of the project.

The project manager will be responsible for all aspects of an assigned construction project. The ORNL project manager will resolve all ES\&H actions recommended by the independent ES\&H oversight function. Those recommendations involving imminent danger will be addressed immediately by on-site personnel. Independent oversight of project activities will be coordinated through a singe overhead organization. ES\&H staff assigned to a project team for planning and surveillance will report to the project manager. ES\&H personnel assigned to project teams must understand that they are on the team to help identify project requirements, plan for provision of those requirements, and assist in surveillance of project activities to ensure compliance with project plans. They are not there to serve as "policemen" of project activities.

Contractors will be held contractually more accountable for the ES\&H aspects of their work through stronger contract administration. By evaluating a contractor's past record of health and safety and environmental protection performance to determine whether it is highly qualified, the overall aspects of construction safety at ORNL will improve.

\subsection{PROJECT CLOSEOUT}

A concentrated effort needs to be made to ensure that as-built drawings and equipment data/operating and maintenance instructions are provided to the facility operator at the end of a project. Project plans and specifications will detail requirements for as-built drawings on the basis of a graded approach as needed for the project. Procedures will be established to ensure that as-built drawings and equipment data/operating instructions are delivered to the end user at the completion of a project. Project cost estimates will provide for as-built drawing and equipment data turnover at the end of the project. Site infrastructure drawings, such as atlas drawings, will be assessed to determine the need for updating as-built drawings. Divisions will be held accountable for updating and maintaining as-built drawings for new facilities and for maintaining the appropriate level of configuration management for operating systems.

The Infrastructure Program Manager will be responsible and accountable for determining how to upgrade the ORNL atlas drawings and drawings for existing infrastructure facilities and for utilizing configuration management for the infrastructure support area in a prioritized manner. 


\section{COST SAVINGS WITH NEW APPROACH FOR SELECTED PROJECTS}

In evaluating the current method of accomplishing ED\&C at ORNL, several repeating patterns highlighted areas where cost improvements should be possible. The primary areas were construction management, labor relations, ES\&H oversight, and the lack of competition for both engineering design and construction contracts-particularly for the latter. A closer review of these areas revealed opportunities for cost improvements.

Since October 1990, a construction manager has been responsible for management of construction at DOE-ORO sites. Originally, the construction manager was a prime contractor to DOE. In October 1995, in an effort to reduce construction costs, the construction manager became a subcontractor to LMES. Cost savings were expected to be realized through elimination of DOE prime contract requirements and reduction in duplication of effort; however, the cost reduction has not been substantial. Table 7 indicates how construction is accomplished at DOE energy research multiprogram laboratories.

Table 7. Methods used by DOE Energy Research multiprogram laboratories to accomplish construction

\begin{tabular}{lccc}
\hline \multicolumn{1}{c}{ Laboratory $^{a}$} & $\begin{array}{c}\text { Construction } \\
\text { manager (Y/N) }\end{array}$ & $\begin{array}{c}\text { Project Labor } \\
\text { Agreement }(\mathrm{Y} / \mathrm{N})\end{array}$ & $\begin{array}{c}\text { FY 1997 construction } \\
\text { expenditure (\$M) }\end{array}$ \\
\hline ANL & $\mathrm{N}$ & $\mathrm{N}$ & 15 \\
LBNL & $\mathrm{N}$ & $\mathrm{N}$ & 15 \\
BNL & $\mathrm{N}$ & $\mathrm{N}$ & 20 \\
ORNL & $\mathrm{Y}$ & $\mathrm{Y}$ & 15 \\
PNNL (private portion) & $\mathrm{N}$ & $\mathrm{N}$ & 2 \\
PNNL (DOE portion) & $\mathrm{Y}$ & $\mathrm{Y}$ & 10 \\
\hline
\end{tabular}

${ }^{a} \mathrm{ANL}=$ Argonne National Laboratory; LBNL - Lawrence Berkeley National Laboratory; BNL = Brookhaven National Laboratory; ORNL = Oak Ridge National Laboratory; PNNL = Pacific Northwest National Laboratory. ${ }^{b} \mathrm{Y}=$ yes; $\mathrm{N}=$ no.

The use of a construction manager increases the cost of construction at ORNL, particularly for small projects. A contributing factor is the decreased annual expenditure for construction. The construction management contract was entered into with the anticipation that the annual expenditure for DOE-ORO sites would be on the order of $\$ 300$ million. During the past 6 years, the annual level has not exceeded $\$ 175$ million. The projected amount for FY 1997 is approximately $\$ 100$ million. In FY 1998, the expenditure is projected to drop to $\$ 50$ million, $\$ 6.8$ million of which is for ORNL construction. The reduced ORNL construction budget for FY 1998 further compromises the justification for having a resident construction manager for LMER-managed projects.

Construction management contracts are normally used on large projects where an owner desires an expert to manage multiple subcontracts. Although ORNL has a few large projects, most range in value from $\$ 100,000$ to $\$ 2,000,000$. Typically, projects include a general contractor under contract to the construction manager and multiple subcontractors under contract to the general contractor. Small- and 
medium-size projects require the same involvement as that seen for larger projects during the solicitation, award, start of work, and work closeout. Consequently, small- and medium-size projects experience a disproportionate amount of construction management cost since costs are billed on a percentage basis against the fixed-price value of contracts awarded by the construction manager. For the MK-Ferguson contract, this amounts to upwards of $30 \%$ of the fixed-price contract amount.

As part of the implementation of using a general construction manager, a PLA was instituted, which restricts any construction contractor doing $D O E$ business to the use of a total of four manual/crafts people of its choosing, with the others selected by the various union business agents that comprise the $\mathrm{KBCTC}$. This requirement, combined with the more restrictive work rules of the KBCTC, results in many construction contractors electing not to bid on ORNL work. The result is a significant reduction in competition and an increase in the cost of construction at ORNL. A comparison of projects completed before and after the PLA became effective indicates a 10 to $15 \%$ increase in the cost of construction at ORNL, depending upon the size of the project, that can be attributed to the PLA.

Surveys and interviews with contractors performing work at ORNL have indicated several factors that drive up costs of construction projects. While the use of a construction manager and a PLA have the greatest impact on costs, there are several smaller elements that result in increased bid prices. Excessive oversight of contractor activities, especially in the area of ES\&H, adds a 3 to $10 \%$ cost increase to bids. Contractors are impacted by blanket work stoppages, specific work slowdowns due to multiple uncoordinated inspections, and conservative safety requirements. All of these factors result in increased bid prices.

All the previously mentioned factors result in cost increases for bids received for construction contracts at ORNL. A long-term impact is the cumulative effect these combined factors have on the bid climate at ORNL. ORNL's reputation for having difficult work conditions reduces the competition for contracts as fewer and fewer contractors bid on work. The most damaging effect is that highly competitive regional contractors refuse to bid on work at ORNL due to these factors. In order for these companies to bid on future projects, long-term changes must be made. While there are no effective means of directly measuring the impact of this loss of competition, it is known to exist.

In 1994, a comparison was made between direct construction costs on the Oak Ridge Reservation and those in the Knoxville area. This comparison was made to determine an index or factor that would show the increased cost of construction on the Oak Ridge Reservation relative to regional construction costs. Comparing eight projects of various types, the overall index was 1.4 higher for construction on the Oak Ridge Reservation (i.e., construction costs were 40\% higher). Indications are that in the 1995-96 time period, this index for some projects rose as high as 1.6.

It is obvious that construction could be accomplished for less cost at ORNL, but it is difficult to determine exactly how much less. While the preceding factors do contribute to higher cost, not all of them can be eliminated. While a general construction manager may not be necessary for the level of construction at ORNL, several of the functions of the construction manager are inherent to successful

*A reference for the information in this paragraph is an October 14, 1994, Martin Marietta Energy Systems, Inc., letter from A. H. Rice (ERWM Engineering Manager) to L. E. Hall (Vice President, ERWM and UE Support, LMES), K. W. Sommerfeld (Vice President, Technical Operations, LMES), and F. C. Larvie (President and General Manager, MK-Ferguson Company of Oak Ridge). 
construction management and must be carried out. The same can be said for ES\&H oversight. Oversight is required, but at a reduced level and in a more coordinated fashion.

In considering possible cost savings, several past, present, and future projects were parametrically estimated using current ED\&C processes and compared against performing the same scope of work using the proposed new ED\&C approach. The new approach assumes that work will be accomplished without a general construction manager or a PLA. Under this approach, the project manager is assumed to have more control and responsibility for ES\&H decisions and direction of the project. Construction support functions are consolidated wherever possible.

The projects estimated include some completed FY 1997 projects, some FY 1998 projects, and some FY 1999 Landlord GPPs. Specifically the projects were as follows:

RH TRU Bunker-A four-bay concrete structure constructed in Melton Valley for the storage of remote-handled transuranic (RH TRU) waste (FY 1997 completed project).

Steam Plant Chimney_Repairs to the steam plant stack (FY 1997 project).

Neutron Science Support Facility-A preengineered, single-story metal building of approximately $5400 \mathrm{ft}^{2}$ with an eave height of $34 \mathrm{ft}$. The building is to be erected over the existing Small-Angle Neutron Scattering Facility.

Upgrade HVAC Unit No. 1,9210 - Provides restoration of adequate airflow to the Air Handler Unit 1 in Building 9210.

Upgrade Condensate Return System-Provides upgrade to the ORNL steam condensate return system by modification of 18 condensate stations.

Pave Gravel Parking Lots-Pave, stripe, and install concrete curbing in the Building 7918 parking lot in the High Flux Isotope Reactor (HFIR) area.

Steel Fuel Oil Storage Tank-A 500,000-gal prefabricated steel storage tank and secondary containment structure to be constructed next to the ORNL steam plant.

Steam Plant Upgrade, No. 5 Boiler-Upgrade the natural gas/fuel oil burners, combustion system auxiliaries, and boiler controls on the No. 5 boiler in the ORNL steam plant.

3000-SCFM Air Compressor-Purchase and installation of an electrically driven, rotary-screw air compressor, complete with necessary electrical control equipment and air receiver, in the ORNL Steam Plant.

Demolish and Replace Building 6003-Demolish and replace Building 6003 with a two-story building of approximately $14,000 \mathrm{ft}^{2}$.

HVAC Upgrade 4500S-Replace the reheat hot-water piping in Building 4500S.

Of the two FY 1997 projects, one had been completed and the other was under construction during this study. Both projects were originally estimated using current approaches to construction even though the construction manager developed the steam plant chimney estimate on the basis of attempting to 
streamline activities. Both of these projects were reestimated based on the proposed new ED\&C approach. Cost savings of approximately $20 \%$ are considered possible if the new approach were used on these two projects.

Fixed construction costs were established for each of the FY 1998 and FY 1999 projects considered. These fixed costs formed the basis for the other parametric cost. The cost categories were planning/design, project management, construction/field support, and overhead. For the new approach, the fixed construction costs were adjusted for consideration of no construction manager and/or no PLA in a manner, depending upon the scope of the work. A commercial perspective to construction was used to estimate the functions under the new approach. Activities normally performed by the construction manager were consolidated into the project management, construction/field support, or overhead functions. Several of the estimates under the current approach were taken from completed estimates included in approved preliminary proposals. The parametric factors as a composite percentage of the fixed-price construction are listed below for the each of the major function areas under the two methods:

\begin{tabular}{|c|c|c|}
\hline Function & Current Approach, \% & New Approach, \% \\
\hline Planning/design & 17.3 & 9.9 \\
\hline Project management & 7.9 & 3.6 \\
\hline Construction/field support & 23.7 & 13.3 \\
\hline Overhead & 20.6 & 8.6 \\
\hline
\end{tabular}

A comparison of the estimates yielded the following possible cost savings using the new approach for the FY 1998 and FY 1999 projects.

\begin{tabular}{lcc}
\multicolumn{1}{c}{ Project } & & Cost Savings, \% \\
\cline { 1 - 1 } Neutron Science Support Facility & 30 \\
Upgrade HVAC Unit No. 1, 9210 & 34 \\
Upgrade Condensate Return System & 36 \\
Pave Gravel Parking Lots & 34 \\
Steel Fuel Oil Storage Tank & 30 \\
Steam Plant Upgrade-No. 5 Boiler & 28 \\
3000-SCFM Air Compressor & 35 \\
Demolish and Replace Building 6003 & 38 \\
HVAC Upgrade 4500S &
\end{tabular}

The net result of using the new approach is that cost savings would be accrued in an amount that would permit additional projects in the ORNL Landlord GPP program to be completed. Under the current FY 1998 funding scenarios ( $\$ 6.8$ million), the last project that could be completed would be the 3000-SCFM air compressor. With the savings realized using the new approach, the two last projects on the list (Demolish and Replace Building 6003 and HVAC Upgrade 4500S) could also be completed during the 
same funding cycle. The addition of these two projects would increase the amount of construction for Landlord-funded infrastructure projects by $33 \%$. The cumulative effect of this paradigm shift would mean that ORNL would be able to complete 4 years' worth of GPPs every 3 years. Demonstrated improved performance of executing capital projects would also have a positive influence on decisions by major DOE sponsors to increase funding for $R \& D$ capital and plant infrastructure improvements at ORNL. 


\section{PLAN FOR IMPLEMENTATION OF NEW ED\&C APPROACH}

Six general activities have been identified that are necessary for implementing the proposed new approach for providing ED\&C support to ORNL divisions and the Infrastructure Manager. Work on these implementation activities began in late FY 1997 and will be completed during FY 1998. At the completion of implementation, ORNL should be in a position to contract for both engineering design services and construction based on the use of a set of Necessary and Sufficient (N\&S) standards for both. Also, guidelines, policies, and procedures should be in place for divisions to have their desired level of involvement in both engineering design and construction activities.

The implementation activities are discussed below in terms of a general description of the activity and the proposed cost and schedule associated with the activity. Summaries of the cost and schedule information are given in Tables 8 and 9 , respectively.

\subsection{ED\&C REENGINEERING IMPLEMENTATION PLAN}

A plan will be developed that describes in detail the various activities to be performed for the implementation of ED\&C reengineering at ORNL by March 1998. The progress of these activities will be tracked throughout the implementation process. Included in this activity is the development of the infrastructure configuration management plan. This plan involves identification, location, and transfer of key drawings of ORNL systems to the Laboratory, as well as definition of the methodology for managing the infrastructure baseline. Funding for this activity is $\$ 21 \mathrm{~K}$ for FY 1997 and $\$ 30 \mathrm{~K}$ for FY 1998. This activity will be completed at the conclusion of all the other ED\&C implementation activities in September 1998.

\subsection{NECESSARY AND SUFFICIENT STANDARDS FOR ENGINEERING DESIGN}

A set of N\&S standards will be developed and implemented for engineering design activities at ORNL. The N\&S set developed by LMES for engineering design will be the starting point of this activity. A team worked to establish N\&S standards for all Oak Ridge sites in FY 1997; however, standards that address hazards to be considered in design at ORNL were not included in the final approved set. An ORNL team will be established to develop a set of N\&S standards for engineering design at ORNL. This activity will begin in FY 1997 with $\$ 21 \mathrm{~K}$ of funding and be completed by June 1998 . Funding for FY 1998 is set at $\$ 80 \mathrm{~K}$.

\subsection{NECESSARY AND SUFFICIENT STANDARDS FOR CONSTRUCTION AND CONSTRUCTION-LIKE ACTIVITIES}

N\&S standards for ORNL construction and construction-like activities were identified in FY 1997. These identified standards must be implemented for the construction process at ORNL. As ORNL begins to develop the process for managing construction, these standards will be implemented into command media and construction documentation. Funding for this activity is $\$ 24.5 \mathrm{~K}$ in FY 1997 and $\$ 50 \mathrm{~K}$ in FY 1998. This activity will be completed in September 1998. 
Table 8. Estimated costs for activities necessary for implementing the proposed new ED\&C approach at ORNL

\begin{tabular}{lcc}
\hline & \multicolumn{2}{c}{$\begin{array}{c}\text { Budget in fiscal year } \\
\text { (\$K) }\end{array}$} \\
\cline { 2 - 3 } & 1997 & 1998 \\
\hline ED\&C reengineering implementation plan & 21 & 30 \\
Development of N\&S standards for engineering design & 21 & 80 \\
$\begin{array}{l}\text { Implementation of N\&S standards for construction and } \\
\text { construction-like activities }\end{array}$ & 24.5 & 50 \\
$\begin{array}{l}\text { Development of ED\&C guidelines, policies, and procedures } \\
\text { Implementation of functions necessary for construction }\end{array}$ & 7 & 70 \\
contracting & 21 & 125 \\
$\begin{array}{l}\text { Development of long-range acquisition strategy for ED\&C } \\
\text { services }\end{array}$ & 14 & 35 \\
$\quad$ Total & 108.5 & 390 \\
\hline
\end{tabular}

Table 9. Scheduled completion dates for activities necessary for implementing the proposed new ED\&C approach at ORNL

ED\&C reengineering implementation plan (Sect. 6.1)

Completion of plan

March 1998

Completion of plan implementation

September 1998

Development of N\&S standards for engineering design (Sect. 6.2)

June 1998

Implementation of N\&S standards for construction and construction-like activities (Sect. 6.3)

September 1998

Development of ED\&C guidelines, policies, and procedures (Sect. 6.4)

June 1998

Implementation of functions necessary for construction contracting (Sect. 6.5)

April 1998

Development of long-range acquisition strategy for ED\&C services (Sect. 6.6)

April 1998

\subsection{ED\&C GUIDELINES, POLICIES, AND PROCEDURES}

Over the past several years, all ORNL design and construction guidance documentation, including procedures, has been controlled by the LMES Central Engineering Services organization. With ORNL coming under a new contract between LMER and DOE and with the recent establishment of ECMD, a need exists for ORNL to develop unique guidelines, policies, and procedures for conducting ED\&C activities. This effort will include a review of existing Central Engineering Services guidelines and 
procedures and determination of their applicability to ORNL. Applicable documentation will be adapted to meet ORNL command media format and content. It is also the intent that divisions have more involvement in the conduct of ED\&C. Guidelines will be developed to establish the methods used at ORNL to obtain ED\&C services and to assist the divisions by providing the necessary information to obtain such services. Funding for this activity is established at \$7K for FY 1997 and \$70K for FY 1998. This activity will be completed by June 1998 .

\subsection{CONSTRUCTION CONTRACTING FOR ORNL}

Construction activities at ORNL are currently managed by an LMES subcontractor, MK-Ferguson of Oak Ridge, through an MOU between LMES and LMER. This MOU is effective through September 1997. Currently, LMES is negotiating a modification to the MK-Ferguson contract for an extension of construction management services, primarily for the Y-12 Plant. ORNL intends to contract directly for construction and will manage our limited construction activities with LMER employees. This activity will establish the process by which construction will be managed by LMER and the process for contracting for construction services at ORNL. Funding is \$21K for FY 1997 and \$125K for FY 1998. ORNL will begin contracting for construction in FY 1998. The actual date will depend upon the requirements for construction. This activity should be fully implemented by April 1998.

\subsection{LONG-RANGE ACQUISITION STRATEGY FOR ED\&C SERVICES}

ECMD will manage general engineering and construction contracts that will be used by ORNL divisions for acquiring $E D \& C$ support. A determination will be made as to the requirements of specific types of services needed to support ORNL. Based upon this determination, contracts that can be accessed by ORNL divisions will be placed with firms. A strategy will be developed that can provide for the long-term needs of these divisions. Funding for this activity is established at $\$ 14 \mathrm{~K}$ for FY 1997 and \$35K for FY 1998. This strategy should be completed by April 1998. 


\section{ACKNOWLEDGMENTS}

The Reengineering Team would like to acknowledge the support and assistance it received from a number of sources. Most importantly, both ORNL and non-ORNL individuals provided invaluable information by returning completed survey questionnaires. These individuals also supplied important information through interviews with Reengineering Team members. Several national laboratories, educational institutions, and $R \& D$ facilities participated in the ED\&C benchmarking activity.

The team also expresses special thanks to Dr. John R. Trabalka, who developed a near-final version of the present report from the team's collection of viewgraph presentations and draft subteam reports. The resulting report was prepared in a very short time over a holiday period, with little input from the team, and reflected with a high degree of fidelity the team's full intent, caveats, and nuances and the spirit in which information, conclusions, and recommendations had been developed. Dr. Trabalka's ability to prepare a draft report of this caliber demonstrates his broad perspective of ORNL as a multifaceted R\&D institution and his skill in bringing order and logic to a rough assemblage of diverse information.

The team also is grateful to Dr. Marsha K. Savage and Deborah P. Stevens, who provided technical editing of the team's report. Their work was also accomplished in an expeditious manner over the yearend holiday period.

The ED\&C Reengineering Team appreciates the valuable assistance of Ellie Read of LMES Quality Services and John Draper of the Robotics and Process Systems Division, who advised the team during the survey design and implementation effort. Ms. Read distributed the surveys and compiled survey results, for which we express our thanks.

The authors wish to acknowledge the contribution of Vivian Marshall in preparation of process maps for the existing ED\&C process at ORNL. Ms. Marshall's efforts stimulated the team's thinking and organized the team's knowledge of ED\&C activities into concise process maps. These process maps indicated many inefficiencies in the ED\&C process for the Reengineering Team to address.

The Building 2033 Conference Room and adjacent breakout room made it possible to have excellent team interactions and effective brainstorming sessions. The team acknowledges Carolyn Rayder for coordinating the use of these facilities and providing supplemental office supplies on demand. Ms. Rayder's outstanding assistance greatly improved the efficiency of the team's activities. 
Appendix A

ENGINEERING DESIGN AND CONSTRUCTION CHARTER 



\section{ENGINEERING DESIGN AND CONSTRUCTION CHARTER}

The Engineering Design and Construction Reengineering Team is charged with the responsibility for developing the vision, approach(es), organizational philosophy, and implementation plan for providing ORNL R\&D staff ready access to cost-effective, customer-oriented engineering design and construction (ED\&C) services and for minimizing the impacts (including costs) of construction activities that occur in or near facilities on which ORNL R\&D staff are dependent. The team approach will include the following tasks:

- Focus on both the research customer and the Laboratory infrastructure needs to maintain a viable and competitive national laboratory.

- Identify unmet ED\&C needs being experienced by the ORNL R\&D divisions and staff as well as ORNL infrastructure support organizations which are related to current approaches to ED\&C activities via discussions with affected division/program directors and staff.

- Devise strategies for overcoming current ED\&C barriers and for facilitating access by ORNL R\&D divisions and infrastructure support organizations to cost-effective, high-quality ED\&C services available within the United States.

- Identify ED\&C approaches at DOE and federal laboratories as well as other institutions and businesses such as universities, federal installations, and commercial enterprises; and benchmark the most effective of these approaches for potential implementation at ORNL.

- Determine the existing ED\&C resources within ORNL R\&D divisions as input to understanding the effectiveness of current ED\&C approaches and the need for flexibility in the recommended approach(es) ORNL R\&D divisions should have available to access ED\&C services.

- Ensure that ORNL R\&D organizations have the flexibility to utilize ED\&C resources internal to ORNL R\&D divisions, when required or when judged to be advantageous, and identify any unmet ED\&C needs that these ORNL R\&D organizations have.

- Ensure that the ORNL ED\&C customer can retain full control of financial assets associated with ED\&C activities for which he/she is responsible and accountable.

- Recognize that the ORNL R\&D staff can be impacted in a number of ways related to ED\&C activities which range from cost impacts on programmatic funds or impacts of not having equipment or facilities when needed to unfunded collateral impacts that occur during construction activities in or near R\&D facilities.

- Take into consideration Work Smart Standards approved through the Necessary and Sufficient Process that are applicable to ORNL ED\&C activities.

- Identify applicable design standards and criteria for the range of ED\&C activities that can be anticipated within ORNL and a graded approach that can be used by division/program directors for determining applicable design standards and criteria for specific ED\&C activities for which they are responsible and accountable. The team should adopt as a goal the utilization of "industrial standards" and provide recommendations for progress toward this goal. 
- Recognize and fully integrate the responsibility and accountability of ORNL facility managers into the recommended ED\&C approach(es).

- Identify the applicable requirements of the Davis-Bacon Act, and explore more flexible approaches to construction activities in order to minimize cost and increase the level of ED\&C responsiveness to needs of the ORNL R\&D staff.

- Identify infrastructure ED\&C functions required to support a world-class multiprogram $R \& D$ laboratory.

- Develop a road map for implementing the resulting ED\&C process and organizational recommendations, including trackable performance metrics against which progress can be measured.

- Identify cost savings expected to accrue from the recommended approach(es), recognizing that reengineering typically yields improvements in cost effectiveness of up to $40 \%$.

- The team will meet with the Reengineering Steering Committee on a regular basis to report on progress and discuss related issues. Deliverables, which are due May 15, 1997, include the recommended approach(es) for ED\&C activities, the scope and ED\&C support that should be made available through an ORNL ED\&C group, and recommendations for management of construction activities. 
Appendix B

MEMBERS OF THE ED\&C REENGINEERING TEAM 



\section{MEMBERS OF THE ED\&C REENGINEERING TEAM}

\section{R\&D Divisions}

S. E. (Steve) Burnette, Group Leader, Design Engineering, Research Reactors Division

E. C. (Ted) Fox, Director, Engineering Technology Division

J. N. (Joe) Herndon, Director, Robotics and Process Systems Division

R. C. (Ray) Juras, Group Leader, Engineering Organization, Physics Division

L. E. (Gene) McNeese (Team Leader), Director, Chemical Technology Division

B. D. (Brad) Patton, Head, Radiochemical Technology Section, Chemical Technology Division

\section{Infrastructure Support Organizations}

J. T. (Tom) Etheridge, Group Leader, Project Management Group, ORNL Engineering and Construction Management Division

E. H. (Ed) Krieg, Director, ORNL Engineering and Construction Management Division

J. W. (Jim) Mathys, Utilities Engineer, Plant and Equipment Division

A. R. (Tony) Medley, Capital Assets Manager, Central Management Offices

T. E. (Tim) Myrick, Director, ORNL Environmental Programs Office

J. A. (Joe) Setaro, Technical Assistant to Associate Director for Operations, Environment, Safety and Health, Central Management Offices

\section{DOE-Oak Ridge}

S. D. (Stan) Frey, ORNL Site Office, DOE-Oak Ridge

L. C. (Larry) Kelly, Project Management Division, DOE-Oak Ridge 

Appendix C

SUBTEAM REPORTS 



\section{C.1 SURVEYS}

\section{C.1.1 Process}

Written surveys were one of several information-gathering approaches used to investigate potential barriers identified by the Reengineering Team through studies of the existing engineering design and construction process. The Reengineering Team divided into subteams for data gathering. Written surveys were developed to aid the subteam studying project risk and the subteam studying impacts of labor standards determination (Davis-Bacon Act or Service Contract Act), the Project Labor Agreement, and LMER contract provisions.

Written surveys were sent to four groups: (1) customers of the ORNL Engineering and Construction Management Division (ECMD), (2) project engineers in ECMD and in the Engineering Technology Division, (3) ES\&H personnel, and (4) construction contractors. Survey response statistics were as follows:

\begin{tabular}{lccc}
\hline & Sent & Received & $\begin{array}{c}\text { Percent } \\
\text { returned }\end{array}$ \\
\hline ECMD customers & 91 & 29 & $32 \%$ \\
Project engineers & 23 & 20 & $87 \%$ \\
ES\&H personnel & 22 & 7 & $32 \%$ \\
$\begin{array}{l}\text { Construction } \\
\text { contractors }\end{array}$ & 24 & 13 & $54 \%$ \\
Total & 160 & 69 & $43 \%$ \\
\hline
\end{tabular}

Surveys were tailored to suit each group but included many of the same questions to allow responses among groups to be compared. ECMD customer surveys and project engineer surveys included questions in the areas of design and construction risk, maintenance and construction management, and the labor standards review process and general issues. Surveys sent to ES\&H personnel included questions in the areas of System Requirements Document preparation, project design, and ES\&H issues. Construction contractor surveys included questions in the areas of design and construction risk, the PLA, and general issues.

\section{C.1.2 Results of the Engineering Design and Construction Process Survey}

\section{C.1.2.1 Summary of Responses from Customers}

For each question, the number and percentage of respondents who selected a particular answer are shown in front of or below that answer, depending on the format of the question. Note that the percentage is calculated from the total number of respondents who answered the question after the "Don't Know/Not Applicable/No Opinion" responses were excluded. The total number of respondents is shown at the left margin. No percentages are shown for the "mark-all-that-apply" questions. There were 29 respondents to this survey. 


\section{Design and Construction Risk}

Size of the project referred to:

2 Less than $\$ 100 \mathrm{~K}$

1 Greater than or equal to $\$ 100 \mathrm{~K}$ but less than $\$ 350 \mathrm{~K}$

14 Greater than or equal to $\$ 350 \mathrm{~K}$ but less than $\$ 2 \mathrm{M}$

8 Greater than or equal to $\$ 2 \mathrm{M}$

4 Unspecified

\section{Systems Requirements Document}

1. a) Did you participate in the development of a Systems Requirements Document for this project?

$$
\begin{array}{llll}
\mathrm{N}=23 & 12(52.2 \%) & \text { Yes } & 11(47.8 \%)
\end{array}
$$

b) Did anyone else from your organization participate in the development of a Systems Requirements Document for this project?
$\mathrm{N}=20$
$16(80.0 \%)$ Yes
$4(20.0 \%)$ No

c) If someone else did participate, at what level did this participation occur? Mark all that apply.

2 Division Director

5 Operator of the finished product

5 Section head

$1 \quad$ P\&E person assigned to the facility

5 Group leader

7 Other (see Comments for descriptions)

\begin{tabular}{|c|c|c|c|c|c|}
\hline & $\begin{array}{c}\text { Totally } \\
\text { Insufficient }\end{array}$ & & Just Right & & $\begin{array}{l}\text { Totally } \\
\text { Excessive }\end{array}$ \\
\hline$N=16$ & 0 & $1(6.3 \%)$ & $8(50.0 \%)$ & $6(37.5 \%)$ & $1(6.3 \%)$ \\
\hline
\end{tabular}

2. How much effort was made during preparation of the Systems Requirements Document to manage the Environmental, Safety and Health (ES\&H) risk associated with the project?

\begin{tabular}{|c|c|c|c|c|c|}
\hline & $\begin{array}{c}\text { Totally } \\
\text { Insufficient }\end{array}$ & & Just Right & & $\begin{array}{c}\text { Totally } \\
\text { Excessive }\end{array}$ \\
\hline$N=14$ & $2(14.3 \%)$ & $5(35.7 \%)$ & $5(35.7 \%)$ & $2(14.3 \%)$ & 0 \\
\hline
\end{tabular}

3. How much effort was made during preparation of the Systems Requirements Document to manage the marginal cost risk associated with the project? 
4. How much effort was made during preparation of the Systems Requirements Document to manage the complexity of the project?

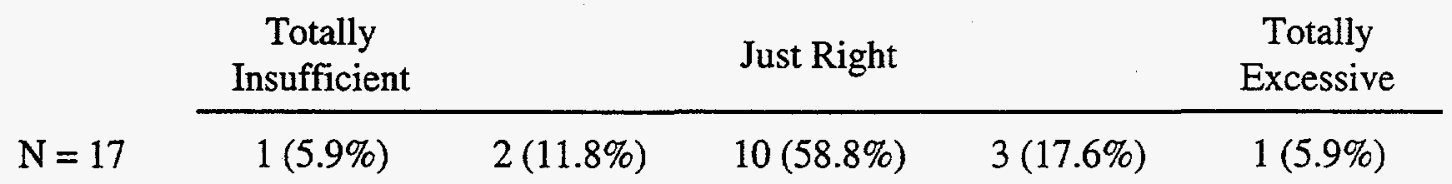

5. Who in your organization reviewed and/or approved the Systems Requirements Document? Mark all that apply.

Division director

Section head

Group leader

Operator of the finished product

P\&E person assigned to the facility

Other (see comments for descriptions)

$\begin{array}{ccc}\text { Reviewed } & & \text { Approved } \\ 8 & & 8 \\ 9 & 9 \\ 6 & 5 \\ 3 & 3 \\ 9 & & 1 \\ & & 7\end{array}$

\section{Project Design}

6. Who performed the design phase of the project?

10 LMES/LMER Engineering

11 Outside Engineering Firm

2 LMES/LMER Engineering AND Outside Engineering Firm

2 LMES/LMER Engineering AND Other (see comments for Other description)

4 Unspecified

7. To what extent were you or your organization involved in the selection of the design organization?

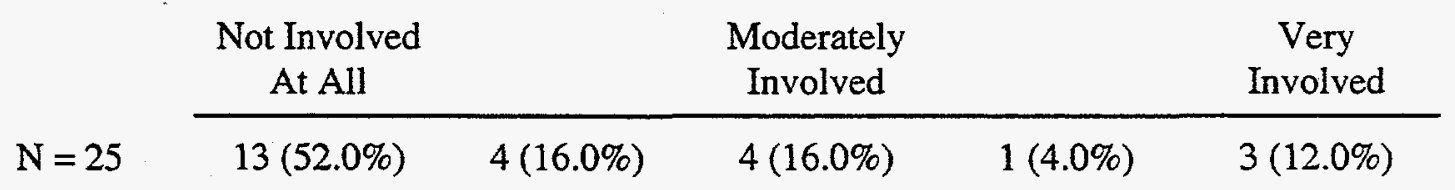

8. How satisfied were you with the work performed by the design organization?

\begin{tabular}{|c|c|c|c|c|}
\hline & $\begin{array}{l}\text { Completely } \\
\text { Dissatisfied }\end{array}$ & Neutral & & $\begin{array}{c}\text { Completely } \\
\text { Satisfied }\end{array}$ \\
\hline$N=24$ & $1(4.2 \%)$ & $9(37.5 \%)$ & $7(29.2 \%)$ & $1(4.2 \%)$ \\
\hline
\end{tabular}


9. How much effort was made during the design phase to manage the ES\&H risk associated with the project?

\begin{tabular}{|c|c|c|c|c|}
\hline & $\begin{array}{c}\text { Totally } \\
\text { Insufficient }\end{array}$ & $\begin{array}{c}\text { Just } \\
\text { Right }\end{array}$ & & $\begin{array}{c}\text { Totally } \\
\text { Excessive }\end{array}$ \\
\hline$N=18$ & 0 & $3(16.7 \%)$ & $6(33.3 \%)$ & $1(5.6 \%)$ \\
\hline
\end{tabular}

10. How much effort was made during the design phase to manage the marginal cost risk associated with the project?

\begin{tabular}{|c|c|c|c|c|}
\hline & $\begin{array}{c}\text { Totally } \\
\text { Insufficient }\end{array}$ & $\begin{array}{l}\text { Just } \\
\text { Right }\end{array}$ & & $\begin{array}{c}\text { Totally } \\
\text { Excessive }\end{array}$ \\
\hline$N=17$ & 0 & $5(29.4 \%)$ & $3(17.6 \%)$ & 0 \\
\hline
\end{tabular}

11. How much effort was made during the design phase to manage the complexity of the project?

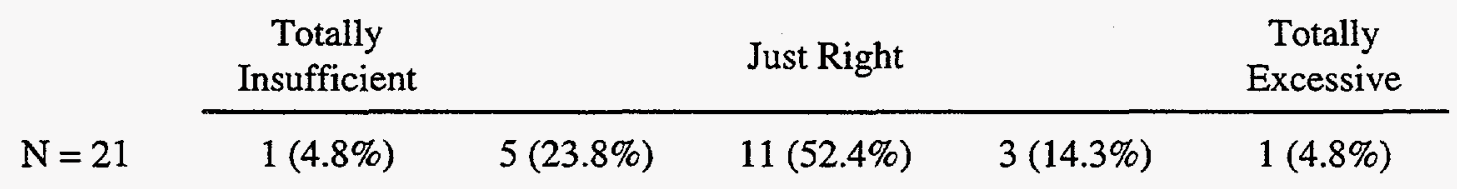

12. During the design phase, how involved was the future operating staff in reviewing the risk associated with operating the facility, equipment, or process following construction?

\begin{tabular}{ccccc} 
& $\begin{array}{c}\text { Totally } \\
\text { Insufficient }\end{array}$ & & Just Right & \multicolumn{1}{c}{$\begin{array}{c}\text { Totally } \\
\text { Excessive }\end{array}$} \\
\cline { 2 - 5 } $\mathrm{N}=22$ & $7(31.8 \%)$ & $12(54.5 \%)$ & $1(4.5 \%)$ & 0
\end{tabular}

13. During the design phase, how much consideration was given to the cost of operating the completed project?

\begin{tabular}{cccccc} 
& \multicolumn{1}{c}{$\begin{array}{c}\text { Totally } \\
\text { Insufficient }\end{array}$} & & Just Right & & $\begin{array}{c}\text { Totally } \\
\text { Excessive }\end{array}$ \\
\cline { 2 - 6 } & $1(4.8 \%)$ & $8(38.1 \%)$ & $11(52.4 \%)$ & $1(4.8 \%)$ & 0
\end{tabular}

14. To what extent did your organization change the design requirements after the project was started?

\begin{tabular}{|c|c|c|c|c|c|}
\hline & $\begin{array}{c}\text { No Changes } \\
\text { At All }\end{array}$ & & $\begin{array}{l}\text { Moderate } \\
\text { Changes }\end{array}$ & & $\begin{array}{c}\text { Many } \\
\text { Changes }\end{array}$ \\
\hline$N=25$ & $2(8.0 \%)$ & $11(44.0 \%)$ & $8(32.0 \%)$ & $3(12.0 \%)$ & $1(4.0 \%)$ \\
\hline
\end{tabular}


15. To what extent was the project cost impacted by changes in design requirements that your organization requested?

\begin{tabular}{|c|c|c|c|c|}
\hline & $\begin{array}{l}\text { Significantly } \\
\text { Increased }\end{array}$ & $\begin{array}{c}\text { Not } \\
\text { Affected }\end{array}$ & & $\begin{array}{c}\text { Significantly } \\
\text { Decreased }\end{array}$ \\
\hline$N=21$ & $1(4.8 \%)$ & $11(52.4 \%)$ & $4(19.0 \%)$ & $2(9.5 \%)$ \\
\hline
\end{tabular}

16. How satisfied were you with the extent to which you and your organization were involved in the design process?

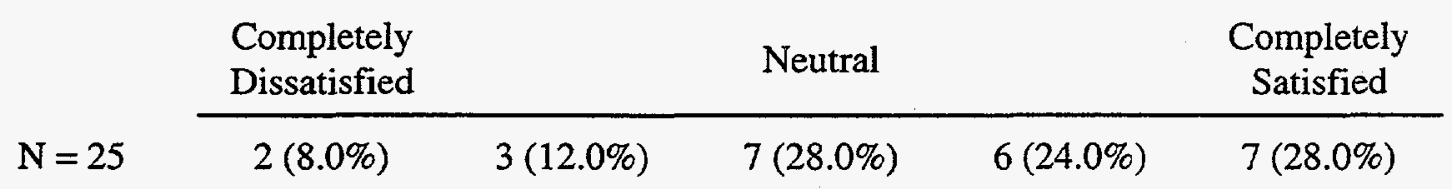

\section{ES\&H Issues}

17. To what extent were construction ES\&H issues addressed in the design phase?

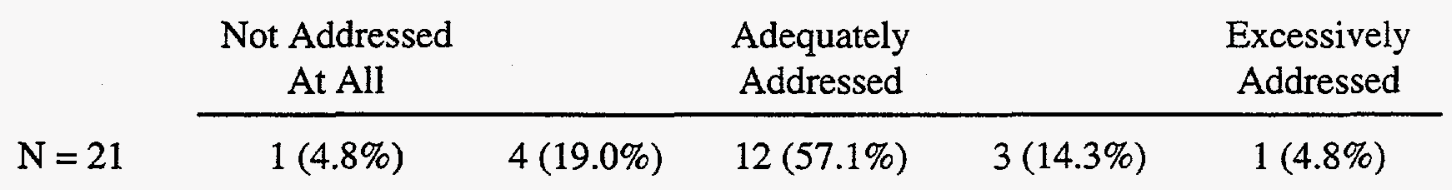

18. To what extent were the construction plans evaluated for compliance with OSHA standards?

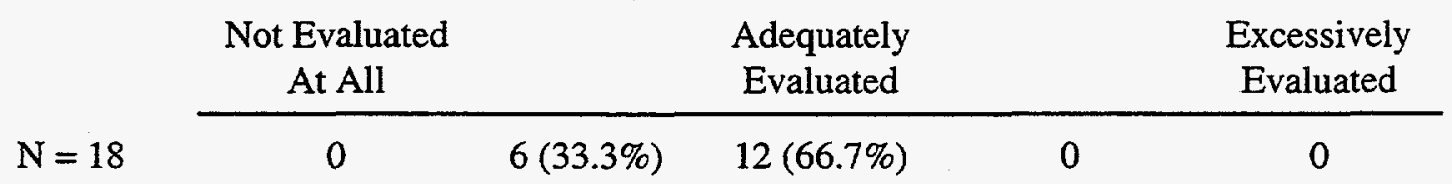

19. How much ES\&H oversight was given to the project to manage the level of hazard on the project?

\begin{tabular}{|c|c|c|c|c|}
\hline & $\begin{array}{c}\text { Totally } \\
\text { Insufficient }\end{array}$ & $\begin{array}{l}\text { Just } \\
\text { Right }\end{array}$ & & $\begin{array}{c}\text { Totally } \\
\text { Excessive }\end{array}$ \\
\hline$N=20$ & 0 & $8(40.0 \%)$ & $6(30.0 \%)$ & $5(25.0 \%)$ \\
\hline
\end{tabular}

20. During construction activities, did you notice representatives from any of the following groups performing ES\&H oversight? Mark all that apply.

18 Construction Contractor's Safety Officer

6 ATLC (Union) Safety Representative

19 MK-Ferguson's ES\&H Representative

18 ORNL Safety and Health Evaluation and Support Team

16 ORNL Division for whom work was being performed 
9 ORNL Safety Department

15 ORNL Radiological Protection

9 ORNL Environmental Compliance and Documentation

4 ORNL Engineering's Electrical Safety Engineering Group

8 ORNL Fire Protection Engineering

3 Office of Operational Readiness and Facility Safety

4 LMES Safety and Health Representative

6 DOE-ORNL Site Office Facility

6 DOE-ORO ES\&H Representative

3 DOE-HQ Safety Representative

4 State of Tennessee ES\&H Representative

2 Other (see Comments for descriptions)

21. a) Were safety and health problems identified by ES\&H oversight?

\begin{tabular}{ccccc} 
& $\begin{array}{c}\text { No } \\
\text { Findings }\end{array}$ & $\begin{array}{c}\text { Minor } \\
\text { Findings }\end{array}$ & $\begin{array}{c}\text { Moderate } \\
\text { Findings }\end{array}$ & $\begin{array}{c}\text { Serious } \\
\text { Findings }\end{array}$ \\
\cline { 2 - 5 } & $6(31.6 \%)$ & $8(42.1 \%)$ & $5(26.3 \%)$ & 0
\end{tabular}

b) If problems were identified, were they corrected?

$$
\mathrm{N}=13 \quad 12(92.3 \%) \text { Yes } 1(7.7 \%) \text { No }
$$

22. To what extent did ES\&H oversight add value to the project?

\begin{tabular}{|c|c|c|c|c|c|}
\hline & $\begin{array}{c}\text { No Value } \\
\text { Added }\end{array}$ & & $\begin{array}{c}\text { Moderate } \\
\text { Value Added }\end{array}$ & & $\begin{array}{c}\text { Significant } \\
\text { Value Added }\end{array}$ \\
\hline$N=22$ & $5(22.7 \%)$ & $8(36.4 \%)$ & $5(22.7 \%)$ & $2(9.1 \%)$ & $2(9.1 \%)$ \\
\hline
\end{tabular}

23. To what extent was the schedule impacted by ES\&H oversight?

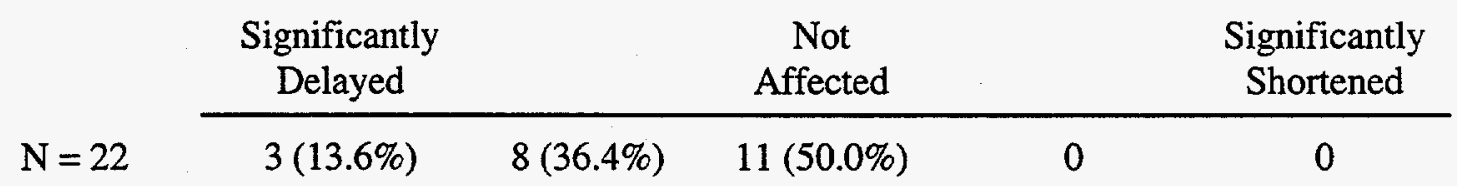

24. To what extent was the project cost impacted by ES\&H oversight?

\begin{tabular}{|c|c|c|c|c|c|}
\hline & $\begin{array}{l}\text { Significantly } \\
\text { Increased }\end{array}$ & & $\begin{array}{c}\text { Not } \\
\text { Affected }\end{array}$ & & $\begin{array}{c}\text { Significantly } \\
\text { Decreased }\end{array}$ \\
\hline $\mathrm{N}=20$ & $3(15.0 \%)$ & $11(55.0 \%)$ & $5(25.0 \%)$ & $1(5.0 \%)$ & 0 \\
\hline
\end{tabular}




\section{Maintenance and Construction Project Management}

27. Who has performed maintenance and construction work in your area? Mark all that apply and indicate the approximate percentage of all work that was done by each provider.

\begin{tabular}{llc}
21 & MK-Ferguson (MK-F) & $\begin{array}{c}\text { Range of } \\
\text { Percentages }\end{array}$ \\
\cline { 3 - 3 } 22 & ORNL Plant and Equipment Division (P\&E) & $5-100$ \\
10 & Other (see Comments for descriptions) & $4-100$
\end{tabular}

28. How satisfied were you generally with the maintenance/construction provider(s)?
Completely
Neutral
Completely
Dissatisfied
Satisfied
a) $\mathrm{MK}-\mathrm{F}, \mathrm{N}=21$
$3(14.3 \%)$
$10(47.6 \%)$
$5(23.8 \%)$
$2(9.5 \%)$
$1(4.8 \%)$
b) $P \& E, N=22$
$4(18.2 \%)$
$8(36.4 \%)$
$9(40.9 \%)$
$1(4.5 \%)$
c) Other, $N=10$
0
2 (20.0\%)
$4(40.0 \%)$
$3(30.0 \%)$
$1(10.0 \%)$

29. How satisfied were you with the cost performance of the maintenance/construction provider(s)?
Completely
Dissatisfied
Neutral
Completely
Satisfied
a) $\mathrm{MK}-\mathrm{F}, \mathrm{N}=21$
$12(57.1 \%)$
$5(23.8 \%)$
$2(9.5 \%)$
$2(9.5 \%)$
0
b) $P \& E, N=21$
$3(14.3 \%)$
$9(42.9 \%)$
$6(28.6 \%)$
$2(9.5 \%)$
$1(4.8 \%)$
c) Other, $\mathrm{N}=8$
$2(25.0 \%)$
$4(50.0 \%) \quad 1(12.5 \%)$
$1(12.5 \%)$

30. How satisfied were you with the schedule performance of the maintenance/construction provider(s)?
Completely
Dissatisfied
Neutral
Completely
$5(23.8 \%)$
$12(57.1 \%)$
3 (14.3\%)
$1(4.8 \%)$
Satisfied
a) $M K-F, N=21$
1 (4.5\%)
9 (40.9\%)
$9(40.9 \%)$
$1(4.5 \%)$
2 (9.1\%)
c) Other, $N=9$
$1(11.1 \%)$
$3(33.3 \%)$
$3(33.3 \%)$
$1(11.1 \%)$
$1(11.1 \%)$ 
31. How satisfied were you with the quality of the final product(s)?

$\begin{array}{lccccc} & \begin{array}{c}\text { Completely } \\ \text { Dissatisfied }\end{array} & & \text { Neutral } & \text { Completely } \\ \text { a) MK-F, } N=20 & 1(5.0 \%) & 8(40.0 \%) & 6(30.0 \%) & 4(20.0 \%) & 1(5.0 \%) \\ \text { b) } \mathrm{P} \& \mathrm{E}, \mathrm{N}=22 & 0 & 5(22.7 \%) & 3(13.6 \%) & 9(40.9 \%) & 5(22.7 \%) \\ \text { c) Other, } \mathrm{N}=9 & 0 & 2(22.2 \%) & 4(44.4 \%) & 3(33.3 \%) & 0\end{array}$

32. How accurately were costs tracked for the project(s)?

\begin{tabular}{lccccc} 
& $\begin{array}{c}\text { Very } \\
\text { Inaccurate }\end{array}$ & & $\begin{array}{c}\text { Moderately } \\
\text { Accurate }\end{array}$ & $\begin{array}{c}\text { Very } \\
\text { Accurate }\end{array}$ \\
\cline { 2 - 6 } a) MK-F, $\mathrm{N}=15$ & $2(13.3 \%)$ & $3(20.0 \%)$ & $5(33.3 \%)$ & $2(13.3 \%)$ & $3(20.0 \%)$ \\
b) P\&E, $\mathrm{N}=18$ & $1(5.6 \%)$ & $4(22.2 \%)$ & $11(61.1 \%)$ & $1(5.6 \%)$ & $1(5.6 \%)$ \\
c) Other, $\mathrm{N}=6$ & $1(16.7 \%)$ & $1(16.7 \%)$ & $2(33.3 \%)$ & $2(33.3 \%)$ & 0
\end{tabular}

33. How accurately were costs charged for the project(s)?

\begin{tabular}{lccccc} 
& \multicolumn{1}{c}{$\begin{array}{c}\text { Very } \\
\text { Inaccurate }\end{array}$} & & $\begin{array}{c}\text { Moderately } \\
\text { Accurate }\end{array}$ & $\begin{array}{c}\text { Very } \\
\text { Accurate }\end{array}$ \\
\cline { 2 - 6 } a) $\mathrm{MK}-\mathrm{F}, \mathrm{N}=17$ & $2(11.8 \%)$ & $5(29.4 \%)$ & $6(35.3 \%)$ & $1(5.9 \%)$ & $3(17.6 \%)$ \\
b) $\mathrm{P} \& \mathrm{E}, \mathrm{N}=19$ & $1(5.3 \%)$ & $3(15.8 \%)$ & $12(63.2 \%)$ & $2(10.5 \%)$ & $1(5.3 \%)$ \\
c) Other, $\mathrm{N}=7$ & $1(14.3 \%)$ & $1(14.3 \%)$ & $4(57.1 \%)$ & $1(14.3 \%)$ & 0
\end{tabular}

34. What was the level of productivity on your project(s)?

\begin{tabular}{lccccc} 
& $\begin{array}{c}\text { Very } \\
\text { Low }\end{array}$ & & Moderate & & $\begin{array}{c}\text { Very } \\
\text { High }\end{array}$ \\
\cline { 2 - 6 } a) MK-F, $N=21$ & $7(33.3 \%)$ & $6(28.6 \%)$ & $8(38.1 \%)$ & 0 & 0 \\
b) $\mathrm{P} \& \mathrm{E}, \mathrm{N}=22$ & $2(9.1 \%)$ & $9(40.9 \%)$ & $11(50.0 \%)$ & 0 & 0 \\
c) Other, $\mathrm{N}=8$ & 0 & $2(25.0 \%)$ & $3(37.5 \%)$ & $1(12.5 \%)$ & $2(25.0 \%)$
\end{tabular}


35. How satisfied were you with the amount of time you had to spend initiating and following through on the project(s)?

\begin{tabular}{lccccc} 
& \multicolumn{2}{c}{$\begin{array}{c}\text { Completely } \\
\text { Dissatisfied }\end{array}$} & & Neutral & $\begin{array}{c}\text { Completely } \\
\text { Satisfied }\end{array}$ \\
\cline { 2 - 6 } a) $\mathrm{MK}-\mathrm{F}, \mathrm{N}=21$ & $3(14.3 \%)$ & $9(42.9 \%)$ & $8(38.1 \%)$ & $1(4.8 \%)$ & 0 \\
b) $\mathrm{P} \& \mathrm{E}, \mathrm{N}=22$ & 0 & $8(36.4 \%)$ & $12(54.5 \%)$ & $2(9.1 \%)$ & 0 \\
c) Other, $\mathrm{N}=9$ & $1(11.1 \%)$ & $1(11.1 \%)$ & $4(44.4 \%)$ & $3(33.3 \%)$ & 0
\end{tabular}

36. How satisfied were you with the amount of time it took to begin the maintenance/construction work?

\begin{tabular}{|c|c|c|c|c|c|}
\hline & $\begin{array}{l}\text { Completely } \\
\text { Dissatisfied }\end{array}$ & & Neutral & & $\begin{array}{l}\text { Completely } \\
\text { Satisfied }\end{array}$ \\
\hline a) $M K-F, N=20$ & $8(40.0 \%)$ & $8(40.0 \%)$ & $1(5.0 \%)$ & $3(15.0 \%)$ & 0 \\
\hline b) $P \& E, N=22$ & $2(9.1 \%)$ & $7(31.8 \%)$ & $7(31.8 \%)$ & $5(22.7 \%)$ & $1(4.5 \%)$ \\
\hline c) Other, $N=9$ & $1(11.1 \%)$ & $3(33.3 \%)$ & $1(11.1 \%)$ & $4(44.4 \%)$ & 0 \\
\hline
\end{tabular}

37. How satisfied were you with the amount of time it took to complete the whole maintenance/construction process?

\begin{tabular}{|c|c|c|c|c|c|}
\hline & $\begin{array}{l}\text { Completely } \\
\text { Dissatisfied }\end{array}$ & & Neutral & & $\begin{array}{c}\text { Completely } \\
\text { Satisfied }\end{array}$ \\
\hline a) $\mathrm{MK}-\mathrm{F}, \mathrm{N}=19$ & $9(47.4 \%)$ & $7(36.8 \%)$ & $2(10.5 \%)$ & $1(5.3 \%)$ & 0 \\
\hline b) $P \& E, N=21$ & $3(14.3 \%)$ & $5(23.8 \%)$ & $9(42.9 \%)$ & $3(14.3 \%)$ & $1(4.8 \%)$ \\
\hline c) Other, $N=9$ & 0 & $4(44.4 \%)$ & $1(11.1 \%)$ & $4(44.4 \%)$ & 0 \\
\hline
\end{tabular}

38. For each of the project sizes shown below, who do you feel is best qualified to perform maintenance/construction activities at ORNL? Mark only one provider within each size category.
a) $<\$ 100 \mathrm{~K}, \mathrm{~N}=20$
b) $\$ 100 \mathrm{~K}$ to $<\$ 350 \mathrm{~K}, \mathrm{~N}=19$
$0 \quad 12(63.2 \%)$
7 (36.8\%)
c) $\$ 350 \mathrm{~K}$ to $\angle \$ 2 \mathrm{M}, \mathrm{N}=20$
$7(35.0 \%)$
$2(10.0 \%)$
$11(55.0 \%)$
d) $\$ 2 \mathrm{M}, \mathrm{N}=21$
$8(38.1 \%)$
0
$13(61.9 \%)$

\begin{tabular}{ccc} 
MK-F & P\&E & Other \\
\hline 0 & $16(80.0 \%)$ & $4(20.0 \%)$
\end{tabular}


39. For each of the project sizes shown below, which provider do you prefer for performing maintenance/ construction activities at ORNL? Mark only one provider within each size category.
a) $<\$ 100 \mathrm{~K}, \mathrm{~N}=20$
b) $\$ 100 \mathrm{~K}$ to $<\$ 350 \mathrm{~K}, \mathrm{~N}=19$
c) $\$ 350 \mathrm{~K}$ to $<\$ 2 \mathrm{M}, \mathrm{N}=19$
d) $\$ 2 \mathrm{M}, \mathrm{N}=21$

\begin{tabular}{ccc} 
MK-F & P\&E & Other \\
\hline 0 & $16(80.0 \%)$ & $4(20.0 \%)$ \\
0 & $12(63.2 \%)$ & $7(36.8 \%)$ \\
$6(31.6 \%)$ & $4(21.1 \%)$ & $9(47.4 \%)$ \\
$8(38.1 \%)$ & $1(4.8 \%)$ & $12(57.1 \%)$
\end{tabular}

\section{Labor Standards Reviews}

40. Have you been involved in any Labor Standards reviews or issues (Davis-Bacon Act or Service Contract Act)?

$$
\mathrm{N}=24 \quad 16(66.7 \%) \text { Yes } \quad 8(33.3 \%) \text { No }
$$

\begin{tabular}{|c|c|c|c|c|c|}
\hline & $\begin{array}{c}\text { Less than } \\
1 \text { week }\end{array}$ & $\begin{array}{c}1-2 \\
\text { weeks }\end{array}$ & $\begin{array}{c}2-3 \\
\text { weeks }\end{array}$ & $\begin{array}{c}3-4 \\
\text { weeks }\end{array}$ & $\begin{array}{c}\text { More than } \\
4 \text { weeks }\end{array}$ \\
\hline$N=15$ & 0 & $1(6.7 \%)$ & $3(20.0 \%)$ & $2(13.3 \%)$ & $9(60.0 \%)$ \\
\hline
\end{tabular}

41. How much time is required for a typical Labor Standards review?

42. To what extent did the time required for Labor Standards rulings impact the schedule of a typical project?

\begin{tabular}{|c|c|c|c|c|c|}
\hline & 1 time & 2 times & 3 times & 4 times & $>4$ times \\
\hline$N=12$ & $6(50.0 \%)$ & $6(50.0 \%)$ & 0 & 0 & 0 \\
\hline
\end{tabular}

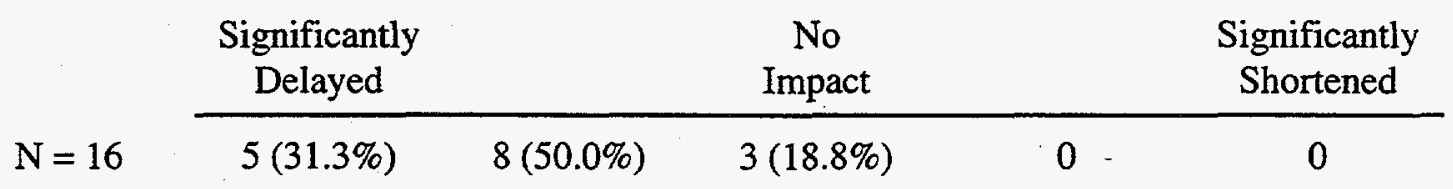

43. On a typical project, how often do you have to interact with Labor Standards to receive a ruling?

44. On a typical project, which of the following was the most common reason for interacting with Labor Standards?

$$
\begin{array}{cl}
\mathrm{N}=14 & \\
2(14.3 \%) & \text { Insufficient information } \\
0 & \text { Incorrectly filled out forms } \\
2(14.3 \%) & \text { Incorrect job description }
\end{array}
$$


$8(57.1 \%)$ Disagreement about ruling

$2(14.3 \%)$ Other (see Comments for descriptions)

45. How many requests for ruling go through without a problem?

\begin{tabular}{|c|c|c|c|c|c|}
\hline & None & & Half & & All \\
\hline$N=7$ & 0 & $2(28.6 \%)$ & $3(42.9 \%)$ & $2(28.6 \%)$ & 0 \\
\hline
\end{tabular}

46. How consistent have the Labor Standards rulings been for similar projects?

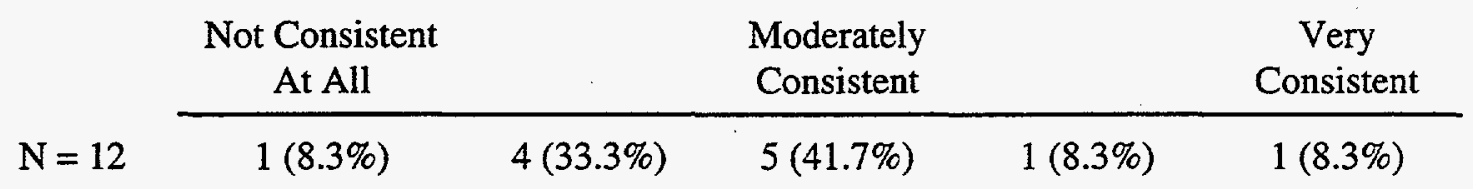

\section{General}

48. In general, how much project planning was performed on the project?

\begin{tabular}{|c|c|c|c|c|c|}
\hline & $\begin{array}{c}\text { Totally } \\
\text { Insufficient }\end{array}$ & & Just Right & & $\begin{array}{l}\text { Totally } \\
\text { Excessive }\end{array}$ \\
\hline $\mathrm{N}=21$ & $1(4.8 \%)$ & $3(14.3 \%)$ & $10(47.6 \%)$ & $5(23.8 \%)$ & $2(9.5 \%)$ \\
\hline
\end{tabular}

49. How would you rate the current process for obtaining construction services from MK-Ferguson?

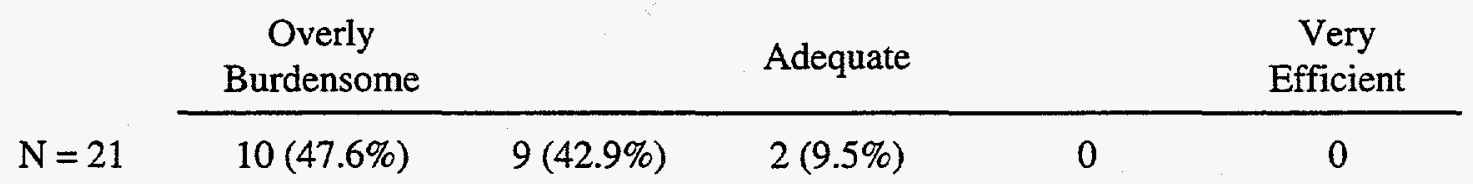

50. How would you rate the current process for obtaining maintenance services from P\&E?

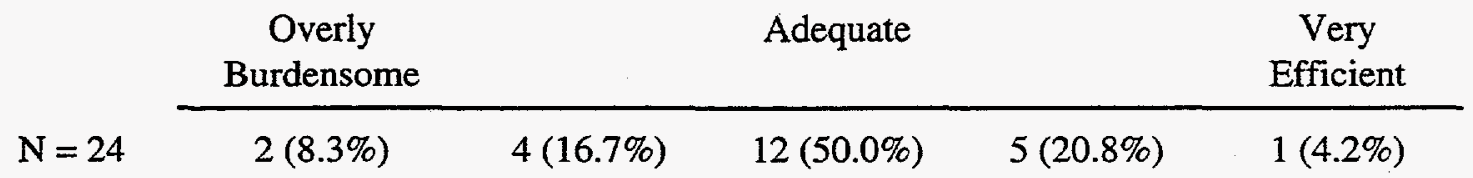

54. What experience did you base your survey responses on?

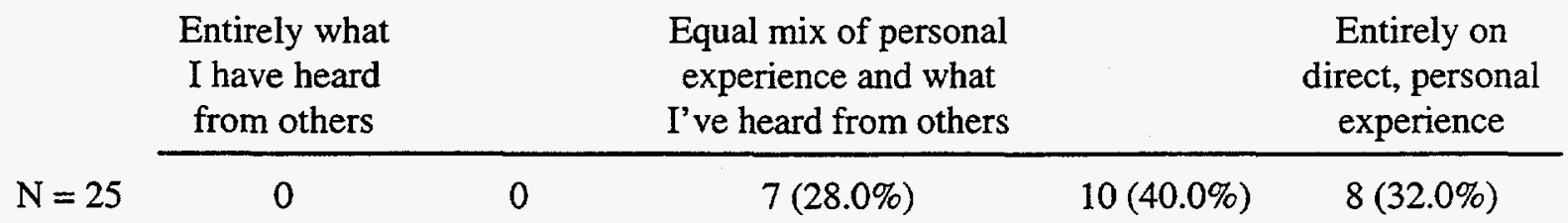


Note: For "mark-all-that-apply" questions, the number of times a choice was marked is shown in the "Yes \#" column. No percentages are shown for these questions.

\begin{tabular}{|c|c|c|c|c|c|}
\hline \multicolumn{6}{|c|}{ Engineering Design and Construction Process Survey } \\
\hline \multicolumn{6}{|l|}{ Summary of Yes/No Responses from Customers } \\
\hline & & \multicolumn{2}{|c|}{ Yes } & \multicolumn{2}{|c|}{ No } \\
\hline Question & $\mathrm{N}$ & \# & $\%$ & \# & $\%$ \\
\hline \multicolumn{6}{|l|}{ Design and Construction Risk } \\
\hline \multicolumn{6}{|l|}{ Systems Requirements Document } \\
\hline $\begin{array}{l}\text { 1a. Did you participate in the development of a Systems Requirements } \\
\text { Document for this project? }\end{array}$ & 23 & 12 & 52.2 & 11 & 47.8 \\
\hline $\begin{array}{l}\text { 1b. Did anyone else from your organization participate in the development of } \\
\text { a Systems Requirements Document for this project? }\end{array}$ & 20 & 16 & 80.0 & 4 & 20.0 \\
\hline \multicolumn{6}{|l|}{$\begin{array}{l}\text { 1c. If someone else did participate, at what level did this participation occur? } \\
\text { Mark all that apply. }\end{array}$} \\
\hline Division Director & & 2 & & & \\
\hline Section Head & & 5 & & & \\
\hline Group Leader & & 5 & & & \\
\hline Operator of the finished product & & 5 & & & \\
\hline P\&E person assigned to the facility & & 1 & & & \\
\hline Other & & 7 & & & \\
\hline \multicolumn{6}{|l|}{$\begin{array}{l}\text { 5a. Who in your organization reviewed the Systems Requirements } \\
\text { Document? Mark all that apply. }\end{array}$} \\
\hline Division Director & & 4 & & & \\
\hline Section Head & & 8 & & & \\
\hline Group Leader & & 9 & & & \\
\hline Operator of the finished product & & 6 & & & \\
\hline P\&E person assigned to the facility & & 3 & & & \\
\hline Other & & 9 & & & \\
\hline \multicolumn{6}{|l|}{$\begin{array}{l}\text { 5b. Who in your organization approved the Systems Requirements } \\
\text { Document? Mark all that apply. }\end{array}$} \\
\hline Division Director & & 8 & & & \\
\hline Section Head & & 9 & & & \\
\hline Group Leader & & 5 & & & \\
\hline Operator of the finished product & & 3 & & & \\
\hline P\&E person assigned to the facility & & 1 & & & \\
\hline Other & & 7 & & & \\
\hline \multicolumn{6}{|l|}{ ES\&H Issues } \\
\hline \multicolumn{6}{|l|}{$\begin{array}{l}\text { 20. During construction activities, did you notice representatives from any of } \\
\text { the following groups performing ES\&H oversight? Mark all that apply. }\end{array}$} \\
\hline Construction Contractor's Safety Officer & & 18 & & & \\
\hline ATLC (Union) Safety Representative & & 6 & & & \\
\hline
\end{tabular}




\begin{tabular}{|c|c|c|c|c|c|}
\hline MK-Ferguson ES\&H Representative & & 19 & & & \\
\hline ORNL Safety and Health Evaluation and Support Team & & 18 & & & \\
\hline ORNL Division for whom work was being performed & & 16 & & & \\
\hline ORNL Safety Department & & 9 & & & \\
\hline ORNL Radiological Protection & & 15 & & & \\
\hline ORNL Environmental Compliance and Documentation & & 9 & & & \\
\hline ORNL Engineering's Electrical Safety Engineering Group & & 4 & & & \\
\hline ORNL Fire Protection Engineering & & 8 & & & \\
\hline Office of Operational Readiness and Facility Safety & & 3 & & & \\
\hline LMES Safety and Health Representative & & 4 & & & \\
\hline DOE-ORNL Site Office Facility & & 6 & & & \\
\hline DOE-ORO ES\&H Representative & & 6 & & & \\
\hline DOE-HQ Safety Representative & & 3 & & & \\
\hline State of Tennessee ES\&H Representative & & 4 & & & \\
\hline Other & & 2 & & & \\
\hline $\begin{array}{l}\text { 21b. Were safety and health problems identified by ES\&H oversight } \\
\text { corrected? }\end{array}$ & 13 & 12 & 92.3 & 1 & 7.7 \\
\hline \multicolumn{6}{|l|}{ Maintenance and Construction Project Management } \\
\hline \multicolumn{6}{|l|}{$\begin{array}{l}\text { 27. Who has performed maintenance and construction work in your area? } \\
\text { Mark all that apply. }\end{array}$} \\
\hline MK-Ferguson & & 21 & & & \\
\hline P\&E & & 22 & & & \\
\hline Other & & 10 & & & \\
\hline \multicolumn{6}{|l|}{ Labor Standards Reviews } \\
\hline $\begin{array}{l}\text { 40. Have you been involved in any Labor Standards reviews or issues (Davis- } \\
\text { Bacon or Service Contract Act)? }\end{array}$ & 24 & 16 & 66.7 & 8 & 33.3 \\
\hline
\end{tabular}

\section{C.1.2.2 Written Comments by Customers}

Refer to the identification numbers at the end of the section to determine which groups the numbers on the left designate.

1c. "Other" participants who participated in the development of a Systems Requirements Document for this project.
101 Technical staff
107 Technical staff
108 Facility Engineer
202 Division engineering staff
204 Project team member
309 Safety and Health Evaluation and Support Team (SHEST)
402 Design 
5. "Other" personnel in your organization who reviewed and/or approved the Systems Requirements Document.

101 Program manager (approved), technical staff (reviewed)

102 Project manager (reviewed and approved)

107 Technical staff (reviewed)

108 Facility Engineer (reviewed)

202 RRD Facility Engineer (reviewed and approved), Facility Manager (reviewed and approved), Facility Safety Analyst (reviewed)

204 Robotics (reviewed and approved), Principal Engineer (reviewed and approved)

302 Radiation Protection SME (reviewed)

308 Division Representative (reviewed and approved)

309 Building Engineer (reviewed and approved), SHEST (reviewed and approved), Facility Manager (reviewed and approved)

402 Design (reviewed and approved)

6. "Other" organization who performed the design phase of the project.

103 My group

309 SHEST

13. During the design phase, how much consideration was given to the cost of operating the completed project?

107 Low bids determine component selection, and construction buys many of the components. Consequently, their profit increases if they save dollars on procurement. Operations often end up with low-quality components, particularly in area of valving.

17. To what extent were construction ES\&H issues addressed in the design phase?

202 Addressed at constructibility review of design, which is late in design phase.

20. "Other" representatives who performed ES\&H oversight on the project.

204 TDEC and EPA

207 Project has not been constructed because of ES\&H oversight issues. Delayed two years.

25. What are the barriers to accepting appropriate levels of project risk?

101 DOE's historic mind set of "zero" risk policies. These have often trickled down to contractors in terms of award fees and contract requirements based on zero risk.

107 - Safety requirements: Too many health and safety organizations; they often don't agree with each other. Too much oversight. $\bullet$ Taking small risks to help acquire a large gain is met with obstacles that offset the potential gain. Also there is little reward for taking a reasonable risk.

108 Too many paper filters. Either the manager is willing to sign on for the project risk level(s) or not.

202 - PAAA review process if incident occurs. DOE Occurrence Reporting System.

- Overreaction by ORNL management and DOE Site Office if incident occurs due to accepting risk. 
204 Cost impacts. No clear definition of "appropriate."

205 The assignment of unqualified persons: i.e., a knowledgeable person (SME) should make infield judgements if they are truly qualified/certified, etc.

206 - DOE-HQ requirements in excess of laws. $\bullet$ DOE-ORO requirements that exceed HQ requirements and local laws. $\bullet$ Potential for legal litigation against company. $\bullet$ Site $(X-10)$ requirements that exceed all DOE requirements and applicable laws.

207 DOE punishment for any errors overshadows desire to do work.

209 No logical ones- primarily bureaucratic.

301 - No reward for successful completion of innovative projects, but plenty of punishment for trivial issues. "Not Engineering's money." $\cdot \mathrm{MK}-\mathrm{F}$ is paid on the project size.

302 Upper-level management's expectation of zero risk.

309 Lack of prime contractor understanding of unique history associated with legacy issues of the facility.

310 - Unwillingness of all organizations involved to accept risk. - Organizations that are not willing to take risk experience no impact for having taken that position.

401 People at ORNL seem to have a "zero risk" mentality which is extremely safe but also extremely expensive.

402 - Clarity of what the standard is. $\bullet$ Personal liability. $\bullet$ Non-uniformity of a standard. $\bullet$ Nonrewarding.

26. In what areas does ORNL do very well at accepting appropriate levels of project risk?

101 None come to mind.

107 See number 25. I am not aware of many instances where [ORNL] takes risks, even though the risks may seem "reasonable."

202 Small projects group (LMER Engineering) type projects and P\&E maintenance projects.

204 Most all areas except criticality safety which is too conservative.

205 Fire Protection Engineering.

206 Fire Protection. Industrial Safety.

207. None.

309 Determining safety and health requirements commensurate with the scope of work.

Reengineer out some risk through early, active involvement in design phase and pre-survey of site.

27. "Other" providers who have performed maintenance and construction work in your area.

101 Fixed-price subcontract

103 I\&C

106 Service subs

107 Foley, TAE

108 Y-12 Facility Management Organization

202 Service contractors

204 Service subs

206 Subcontractor

38. Which provider do you feel is best qualified to perform maintenance/construction activities at ORNL?

202 Not dollar driven, but type of work driven. 
39. Which provider do you prefer for performing maintenance/construction activities at ORNL?

202 Not dollar driven, but type of work driven.

$401 \quad \mathrm{P} \& \mathrm{E}$ has better quality work, but very expensive. $\mathrm{MK}-\mathrm{F}$ is cheaper but quality goes down.

41. How much time is required for a typical Labor Standards review?

202 For the review only, 2-3 weeks; total time to prepare paperwork and get review, more than 4 weeks.

45. How many requests for ruling go through without a problem?

202 The ruling on Davis-Bacon is not the problem; the DOE-ORO Construction Manager requirement is the problem.

46. How consistent have the Labor Standards rulings been for similar projects?

Everything is generally ruled construction.

47. If you could start with a "clean sheet," what would your process be for determining whether a job is construction work as defined by the Davis-Bacon Act or service work as defined by the Service Contract Act?

103 I am not familiar enough with these Acts to make a proposal.

105 Small jobs $(<\$ 500 \mathrm{~K})$ are $\mathrm{P} \& \mathrm{E}$. Jobs $>\$ 500 \mathrm{~K}$ are $\mathrm{MK}-\mathrm{F}$.

106 Need to up the dollar amount for consideration if it is construction.

107 (I don't understand how these Acts determine if construction or P\&E personnel are assigned a specific job.) Any competent organization, be it P\&E or Construction, should have an equal shot at doing a given job. What should be monitored is the performance - did the job occur on schedule and within budget? Knowing this, the "customer" should be able to select who does the work and use past performance as the main criteria for selection.

108 Raise the dollar amount.

202 - Have ORNL committee rule on Davis-Bacon for each project. - Have DOE-ORO review this annually. - De-couple Davis-Bacon ruling with DOE-ORO requirement to use a single construction manager. DOE efforts for consistency with a single construction manager add cost and discourage creativity. $\bullet$ Competitively bid or negotiate price with qualified construction vendors; let ORNL manage construction management. $\bullet$ Let Davis-Bacon be wage determination issue only, as is intended in the law.

204 Would look at work scope - not dollar value. The $\$ 2,000$ is very outdated.

206 Cost and impact on operations and level of site knowledge necessary for successful project, and risk to site, and value for taxpayer. $\bullet$ Cost limitation would be increased to $\$ 100 \mathrm{~K}$. - Operational impacts would be taken into account and reviewed. - Site knowledge for success would be defined. $\bullet$ Risk to site and public from work performed by a subcontractor. - What is the best economic value for the taxpayer.

207 Process should be internal to ORNL/LMER with no union involvement.

301 I would follow the example of our competitor labs, such as BNL, ANL, or INEEL. A set of guidelines would be used, and ORNL would make the call. OR would be consulted on "borderline" jobs. One person, part-time. 
302 - Apply the law as it is written, not as it is perceived by some maintenance organizations.

- See what other national laboratories are doing. • Benchmark private industry (Bell Labs, etc.).

307 Only projects above $\$ 50 \mathrm{~K}$ would be considered from Davis-Bacon.

308 All work would be done by most qualified organization with no regard to service or construction.

309 Increase the ceiling for Davis-Bacon reviews to be able to more competitively perform work.

310 Read Davis-Bacon Act and Service Contract Act.

401 It is my understanding that the Davis-Bacon Act only requires that you pay the prevailing wage. I would eliminate other lesser requirements and agreements.

402 I would not make a distinction. We pay prevailing wages in both cases. We need a new criteria for performing work, such as quality, money, and schedule, not layers of redundant oversight.

51. If you could start with a "clean sheet," what would you like to have as ORNL's new Engineering Design and Construction Process?

106 A plan needs to be developed that provides a step flow process so that everyone who needs to provide input on a project (i.e., ES\&H, facility managers, F.D., LSS, Security) knows when to input. Engineering needs to learn how to work with their customers and required disciplines giving input. Customers and others cannot easily work with the complexity of the way Engineering has managed projects in the past. Engineering needs to team with involved parties. Not dictate.

107 In-house construction and design. However, it would be one that promoted competition. This could be accomplished in more than one way (each with its own complications). One way would be to have a pool of crafts people and basically let the customer choose who did the work for him (see number 47).

202 - Each division at ORNL would have the option to contract design services through either LMER Engineering, LMES Engineering or any other pre-qualified A/E. LMER Engineering would assist in this process for divisions without their own engineering support personnel. - Each division at ORNL would have the option to contract construction services with a construction group retained for ORNL work, or with P\&E if resources were available, or with any other pre-qualified construction or service contract vendor. LMER Engineering would provide overall construction management oversight requirements and services if requested by client.

204 - Stand-by unit price sub-bid annually. - More emphasis on design/build.

205 Core Engineering group of knowledgeable employees that have "ears" and can work as a team with customers and ES\&H reviewers. Seeking and discerning good, solid input from knowledgeable people for future safe operation and operability of facility.

206 - Sub out only the design work that in-plant personnel are not qualified to do or that exceeds work load capability of in-plant employees. $\bullet$ Same approach for construction engineering service. $\cdot$ Monetary penalties for not meeting contract/design obligations.

207 Large construction project should be done with fixed-priced contractors to LMER. Small projects should be done by P\&E or a P\&E-like construction force internal to ORNL.

208 I'm not sure what the model should look like. The model/process needs to include the ability to distinguish the level of engineering required for small projects as opposed to large projects.

209 Let ORNL Engineering try projects without MK-F. If that is not cost-effective, then go to outside contractors. MK-F increased cost by about $35 \%$ for precious little value added! 
301 Start with the "Davis-Bacon" example above. Have pre-approved firms that could quickly respond, and use performance contracts. Eliminate MK-F entirely, and hire a Construction Manager for jobs greater than $\$ 2 \mathrm{M}$ or so. Maximize use of the existing P\&E, supplemented by skills as jobs or work load dictate.

303 - I would have liked to provide information to the survey, but our group is small and did not initiate any projects. My reference point is based on past experiences and "things" that I hear in going about the Lab. - I would like to see ORNL's small core Engineering group taking on all projects, doing those smaller ones that they have manpower and expertise to handle, and turning the larger projects to an A/E firm that either had a standing contract to provide support or won the larger projects on an individual bid basis. In all cases, ORNL would act as the overall project engineer, dealing directly with the general contractors without DOE intervention.

307 Eliminate or reduce paperwork. Excessive dollars are spent before ever getting the work started. The whole process and cost make most jobs' cost prohibited. If the process was improved and documentation process shortened, work could be done as efficiently as on the outside. Now work usually costs a factor of ten to what the actual cost should be.

310 - ORNL to access directly design and construction contractors. - No construction manager. - No Project Labor Agreement.

401 A facility manager should be able to hire anyone he wants to do a job. The company or person who designs it should be the one who installs it and makes it run. That eliminates pointing of fingers. "Turnkey" jobs. Contractors who do poorly should not be hired again.

402 - Freedom to do what is considered the best overall approach and not be locked into MK-F or someone else. • Perform work utilizing small multi-skilled teams empowered to make decisions. - The small multi-skilled team must be the correct makeup (i.e., customer, engineer). $\bullet$ Do only what is necessary and sufficient as decided by the technical and safety people and do not commit to following DOE orders. $\bullet$ Follow nationally recognized code and standards. • Have a "graded" approach to quality. - Minimize paperwork. • Simplify the design/construction process.

52. What advice would you give to the Engineering Design and Construction Reengineering Team?

101 I think that the mandated use of the union pool for construction contractors should be reevaluated. Currently, contractors are limited to a maximum number of "core" employees (8?) and the rest must be hired from the trade unions. This has to result in higher construction costs, especially for specialty contractors who usually operate with a well-experienced team (i.e., on-site tank erections).

103 We are experimenters at HFIR, and I would like to see an easier method of obtaining P\&E support for work on our facilities. Right now we are at the whim of RRD and often have to wait long periods of time to get P\&E support services.

106 Structure yourselves so that your customers and others who input to your projects know exactly how to work with you.

107 As before, we need a system which promotes competition. Presently, once work is assigned to either P\&E or Construction, it becomes a closed shop. They have the work with no competition from anyone and we have very limited ability to hold a given organization to meet their schedule or estimate.

108 Verify that the initial cost estimate is in line with the final cost of the job.

202 - BE BOLD - make process changes, not an apple pie/motherhood report. Suggest ORNL serve as construction manager. - Have Basic Order Contracts with qualified vendors to provide services such as road paving, roofing, concrete foundations/pads, etc. Also with 
similar companies to provide craft/trades work such as electricians when needed. All competition for construction from qualified vendors without a Project Labor Agreement. Allow P\&E to bid on construction work. Establish an organization with appropriate funding responsible for an integrated Lab infrastructure configuration control program.

205 Involve knowledgeable people in pre- and conceptual design phases. EARLY.

207 - Fix Davis-Bacon problems and cost drivers. - Eliminate multiple layers of oversight. - Eliminate MK-F.

208 Make it simple; don't protect turf; it's better to save a few than lose the whole.

209 Figure out a way to get rid of MK-F. Allow ORNL Engineering to contract with outside construction companies. Figure out a way to build buildings and do building maintenance for about the cost I can get it done at home.

301 Do not accept modest changes. The current system is a failure, and ORNL's future depends on a workable system. Rice bowls must be broken. The process does not make sense nor add value. Look to industry.

302 - Conduct a benchmarking exercise with private businesses and large private R\&D laboratories to determine ES\&H level of detail and assessment/management of risk for project engineering and subsequent completion of construction. - Determine construction costs at private versus government R\&D and nuclear facilities.

303 I would like to see our Engineering to be able to contract directly with outside AVEs, general contractors, etc., without DOE or MK-F intervention. In other words, function more like a real-world company, to get the most for each dollar spent. Has anyone looked at the possibility of a wholly owned subsidiary company much like the Tennessee Eastman/Bay's Mountain Construction Company concept?

307 The whole process needs improvement.

309 Spend more time on pre-site assessments with customer and earlier involvement from ES\&H on design.

401 Do not allow the conceptual design, final design and entire construction to be done by different companies or divisions. A responsible designer can carry out his project to completion. A poor designer has no one to blame but himself. You must make a change to make a difference!

53. Please write in any other comments you have about your experience with maintenance or construction projects at ORNL.

101 Many times there are little to no positive controls on how CID's affect cost and schedule. CID's are often issued to a FPSC only to have the details of cost and schedule impacts negotiated at a later date (sometimes months/years). This practice gives the FPSC every advantage. Some projects that I've been involved in (i.e., MVST-CIP) have done an excellent job of pre-negotiating and promptly dealing with CID's, but that hasn't been the typical case. Also, more emphasis needs to be given to operational interfaces during design. Often, designs get issued that call for tie-ins to existing systems without consideration to the impact of downtime for the system.

106 There is a big problem of coordinating these projects with the rest of Lab operation. It appears that Engineering and P\&E believe their work takes precedence over everyone else. They set and follow their own time frame for schedules, meetings, etc. They need to learn to coordinate with others.

202 - Allow Engineering to use a graded approach for the amount and detail of documentation required for projects depending on the scope of the project, instead of the full-blown approach for all projects. $\bullet$ Make better use of the network (computer) for project documents 
to reduce duplication of efforts for multiple copies of project descriptions in multiple reports such a QA Plan, Waste Plan, Safety Assessment, etc. Also use this approach for project status reports.

205 Early 90's brought far too much regulatory restriction such as asbestos. This led to far too many people charging to the project, especially "safety" overseers which did not add a lot of value and ran project costs off the deep line (e.g., 4500N Fire Protection Upgrade LIP).

206 Monetary penalties are effective in the private sector. This same approach, if properly enforced, would be effective in ORNL's effort to work with design and construction subcontractors. Over a period of time, this concept would weed-out the poor performers, leaving the quality contractors for conducting business. This may cause an increase in construction bids, but quality always seems to cost more.

207 Interface problems with conducting work through MK-F are unacceptable. Cost of MK-F work is two to three times too high, and use of construction manager is unnecessary.

208 Construction costs are too high and take much too long to end product.

302 - Maintenance organization needs a "just-in-time" type of organization (a clearinghouse) for accomplishing minor maintenance tasks. • Get rid of "parochial" management of resources. Send SME's where they are needed, when they are needed. Raise productivity. Get rid of those persons who "have not seen the handwriting on the wall" for increased efficiency, productivity and mutual assistance between craftsmen.

303 There appear to be too many folks between our Engineering and the subcontractor performing the work. Skimming of dollars for little or no value added.

305 Project estimates and actual costs are too far apart. MK-F will accept a job based on ORNL Engineering estimates and then run the actual costs so far over that your budget is ruined.

401 ORNL desperately needs a configuration control system for the entire plant. Drawing control with Engineering Division is pathetic. Responsible division directors have already taken control of their own drawings in several cases. Excavation permits are a joke because no one knows where the underground equipment is located. An overall drawing control system could help this problem if properly funded.

\section{Identification}

ID numbers beginning with digit " 1 " are major customers, and those with " 2 " are lesser customers. Senior managers begin with " 3 ," and other miscellaneous customers begin with " 4 ."

\begin{tabular}{llll} 
ID & \multicolumn{1}{c}{ Organization $^{\alpha}$} & \multicolumn{1}{c}{ Project size } & Responses based on \\
\hline 101 & & $\$ 2 \mathrm{M}$ & Direct \\
102 & ER Project Manager & $\$ 2 \mathrm{M}$ & Direct \\
103 & ETD & $<\$ 100 \mathrm{~K}$ & Direct/Heard \\
104 & & $\$ 350 \mathrm{~K}$ to $<\$ 2 \mathrm{M}$ & Equal \\
105 & & $\$ 2 \mathrm{M}$ & Direct \\
106 & & $\$ 350 \mathrm{~K}$ to $<\$ 2 \mathrm{M}$ & Direct/Heard \\
107 & WMRAD/LGWO & $\$ 2 \mathrm{M}$ & Direct/Heard \\
108 & Fusion Energy & $\$ 350 \mathrm{~K}$ to $<\$ 2 \mathrm{M}$ & Direct \\
201 & & $\$ 350 \mathrm{~K}$ to $<\$ 2 \mathrm{M}$ & Direct \\
202 & ORNL RRD & $\$ 350 \mathrm{~K}$ to $<\$ 2 \mathrm{M}$ & Equal \\
203 & & Not a recent customer & \\
204 & & $\$ 2 \mathrm{M}$ & Unspecified \\
\hline
\end{tabular}




\begin{tabular}{|c|c|c|c|}
\hline ID & Organization $^{a}$ & Project size & Responses based on ${ }^{b}$ \\
\hline 205 & Fire Protection Engineering & $\$ 2 \mathrm{M}$ & Direct/Heard \\
\hline 206 & Lab Protection & $\$ 2 \mathrm{M}$ & \\
\hline 207 & ORNL CTD & $\$ 350 \mathrm{~K}$ to $<\$ 2 \mathrm{M}$ & Direct/Heard \\
\hline 208 & & $\$ 350 \mathrm{~K}$ to $<\$ 2 \mathrm{M}$ & Direct \\
\hline 209 & ORNL & $<\$ 100 \mathrm{~K}$ & Direct \\
\hline 301 & & $\$ 350 \mathrm{~K}$ to $<\$ 2 \mathrm{M}$ & Direct/Heard \\
\hline 302 & & $\$ 350 \mathrm{~K}$ to $<\$ 2 \mathrm{M}$ & Direct/Heard \\
\hline 303 & Quality Prog. \& Insp. & Not a recent customer & Equal \\
\hline 304 & Business Management & Not a customer & \\
\hline 305 & & $\$ 100 \mathrm{~K}$ to $<\$ 350 \mathrm{~K}$ & Equal \\
\hline 306 & & Not a recent customer & \\
\hline 307 & & $\$ 350 \mathrm{~K}$ to $<\$ 2 \mathrm{M}$ & Direct/Heard \\
\hline 308 & Energy Division & $\$ 350 \mathrm{~K}$ to $<\$ 2 \mathrm{M}$ & Equal \\
\hline 309 & & $\$ 350 \mathrm{~K}$ to $<\$ 2 \mathrm{M}$ & Equal \\
\hline 310 & & $\$ 350 \mathrm{~K}$ to $<\$ 2 \mathrm{M}$ & Equal \\
\hline 401 & WMRAD & $\$ 350 \mathrm{~K}$ to $<\$ 2 \mathrm{M}$ & Direct/Heard \\
\hline 402 & RRD & $\$ 2 M$ & Direct \\
\hline \multicolumn{4}{|c|}{$\begin{array}{l}{ }^{a} \mathrm{CTD}=\text { Chemical Technology Division, ER = Environmental Restoration, ETD = Engineering } \\
\text { Technology Division, WMRAD = Waste Management and Remedial Action Division, } \\
\text { LGWO = Liquid/Gaseous Waste Operations, and } \mathrm{RRD}=\text { Research Reactors Division. } \\
{ }^{b} \text { Heard = Entirely what I have heard from others; Heard/Direct = more what I have heard from } \\
\text { others rather than direct, personal experience; Equal = equal mix of personal experience and what } \\
\text { I've heard from others; Direct/Heard = more direct, personal experience rather than what I have } \\
\text { heard from others; and Direct = entirely on direct, personal experience. }\end{array}$} \\
\hline
\end{tabular}

\section{C.1.2.3 Summary of Responses from Project Engineers and Managers}

For each question, the number and percentage of respondents who selected a particular answer are shown in front of or below that answer, depending on the format of the question. Note that the percentage is calculated from the total number of respondents who answered the question after the "Don't Know/Not Applicable/No Opinion" responses were excluded. The total number of respondents is shown at the left margin. No percentages are shown for the "mark-all-that-apply" questions. There were 20 respondents to this survey.

\section{Design and Construction Risk}

Size of the project referred to:

0 Less than $\$ 100 \mathrm{~K}$

3 Greater than or equal to $\$ 100 \mathrm{~K}$ but less than $\$ 350 \mathrm{~K}$

8 Greater than or equal to $\$ 350 \mathrm{~K}$ but less than $\$ 2 \mathrm{M}$

6 Greater than or equal to $\$ 2 \mathrm{M}$

3 Unspecified 


\section{Systems Requirements Document}

1. a) Did you participate in the development of a Systems Requirements Document for this project?
$\mathrm{N}=20$
$13(65.0 \%)$ Yes
$7(35.0 \%)$ No

b) Did anyone else from your organization participate in the development of a Systems Requirements Document for this project?
$\mathrm{N}=20$
$15(75.0 \%)$ Yes
$5(25.0 \%)$ No

c) If someone else did participate, at what level did this participation occur? Mark all that apply.
1 Division Director
2 Section Head
4 Group Leader
8 Other (See Comments for descriptions)

d) Was the customer involved in the development of a Systems Requirements Document for this project?
$\mathrm{N}=20$
$17(85.0 \%)$ Yes
$3(15.0 \%)$ No

2. How much effort was made during preparation of the Systems Requirements Document to manage the Environmental, Safety and Health (ES\&H) risk associated with the project?

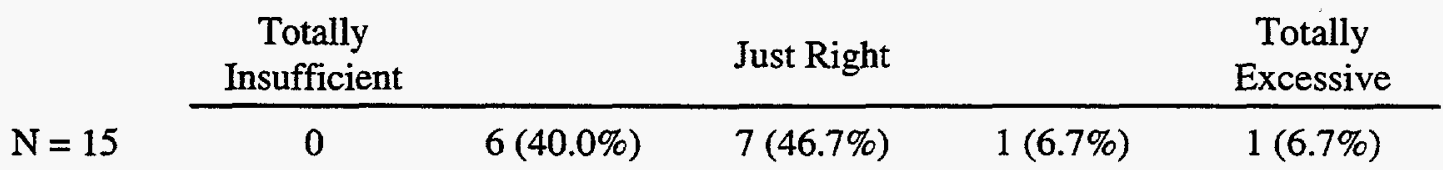

3. How much effort was made during preparation of the Systems Requirements Document to manage the marginal cost risk associated with the project?

\begin{tabular}{|c|c|c|c|c|c|}
\hline & $\begin{array}{c}\text { Totally } \\
\text { Insufficient }\end{array}$ & & Just Right & & $\begin{array}{l}\text { Totally } \\
\text { Excessive }\end{array}$ \\
\hline $\mathrm{N}=15$ & $1(6.7 \%)$ & $5(33.3 \%)$ & $6(40.0 \%)$ & $3(20.0 \%)$ & 0 \\
\hline
\end{tabular}

4. How much effort was made during preparation of the Systems Requirements Document to manage the complexity of the project?

\begin{tabular}{|c|c|c|c|c|c|}
\hline & $\begin{array}{c}\text { Totally } \\
\text { Insufficient }\end{array}$ & & Just Right & & $\begin{array}{c}\text { Totally } \\
\text { Excessive }\end{array}$ \\
\hline$N=15$ & $1(6.7 \%)$ & $3(20.0 \%)$ & $9(60.0 \%)$ & $2(13.3 \%)$ & 0 \\
\hline
\end{tabular}


5. Who reviewed and/or approved the Systems Requirements Document? Mark all that apply.

Engineering Division Director

Engineering Section Head

Engineering Group Leader

Customer's Division ES\&H Officer

Customer's Line Organization

Other (See Comments for descriptions)

\begin{tabular}{|c|c|}
\hline Reviewed & Approved \\
\hline 1 & 2 \\
\hline 3 & 3 \\
\hline 9 & 7 \\
\hline 5 & 2 \\
\hline 11 & 12 \\
\hline 9 & 7 \\
\hline
\end{tabular}

\section{Project Design}

6. Who performed the design phase of the project?

6 LMES/LMER Engineering

11 Outside Engineering Firm

1 LMES/LMER Engineering AND Outside Engineering Firm

2 LMES/LMER Engineering AND Other (See Comments for Other description)

7. To what extent were you or your organization involved in the selection of the design organization?

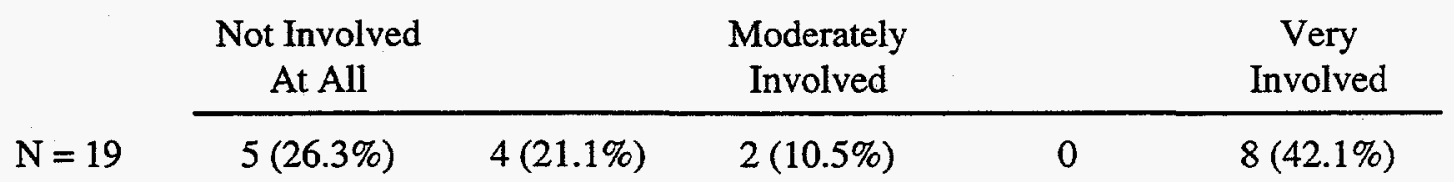

8. How satisfied were you with the work performed by the design organization?

\begin{tabular}{|c|c|c|c|c|c|}
\hline & $\begin{array}{l}\text { Completely } \\
\text { Dissatisfied }\end{array}$ & & Neutral & & $\begin{array}{c}\text { Completely } \\
\text { Satisfied }\end{array}$ \\
\hline $\mathrm{N}=20$ & $2(10.0 \%)$ & $5(25.0 \%)$ & $5(25.0 \%)$ & $4(20.0 \%)$ & $4(20.0 \%)$ \\
\hline
\end{tabular}

9. How much effort was made during the design phase to manage the ES\&H risk associated with the project?

\begin{tabular}{|c|c|c|c|c|c|}
\hline & $\begin{array}{c}\text { Totally } \\
\text { Insufficient }\end{array}$ & & Just Right & & $\begin{array}{c}\text { Totally } \\
\text { Excessive }\end{array}$ \\
\hline$N=18$ & $1(5.6 \%)$ & $3(16.7 \%)$ & $9(50.0 \%)$ & $4(22.2 \%)$ & $1(5.6 \%)$ \\
\hline
\end{tabular}


10. How much effort was made during the design phase to manage the marginal cost risk associated with the project?

\begin{tabular}{|c|c|c|c|c|c|}
\hline & $\begin{array}{c}\text { Totally } \\
\text { Insufficient }\end{array}$ & & Just Right & & $\begin{array}{c}\text { Totally } \\
\text { Excessive }\end{array}$ \\
\hline$N=16$ & $1(6.3 \%)$ & $4(25.0 \%)$ & $8(50.0 \%)$ & $3(18.8 \%)$ & 0 \\
\hline
\end{tabular}

11. How much effort was made during the design phase to manage the complexity of the project?

\begin{tabular}{|c|c|c|c|c|c|}
\hline & $\begin{array}{c}\text { Totally } \\
\text { Insufficient }\end{array}$ & & Just Right & & $\begin{array}{c}\text { Totally } \\
\text { Excessive }\end{array}$ \\
\hline$N=18$ & 0 & $6(33.3 \%)$ & $10(55.6 \%)$ & $1(5.6 \%)$ & $1(5.6 \%)$ \\
\hline
\end{tabular}

12. During the design phase, how involved was the future operating staff in reviewing the risk associated with operating the facility, equipment, or process following construction?

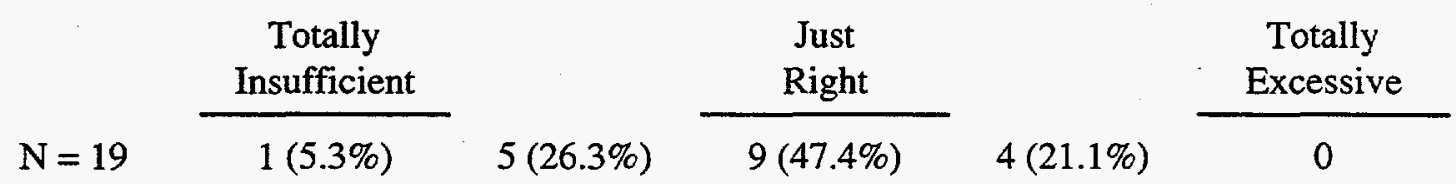

13. During the design phase, how much consideration was given to the cost of operating the completed project?

\begin{tabular}{|c|c|c|c|c|c|}
\hline & $\begin{array}{c}\text { Totally } \\
\text { Insufficient }\end{array}$ & & Just Right & & $\begin{array}{c}\text { Totally } \\
\text { Excessive }\end{array}$ \\
\hline$N=17$ & 0 & $6(35.3 \%)$ & $10(58.8 \%)$ & $1(5.9 \%)$ & 0 \\
\hline
\end{tabular}

14. To what extent did the customer change the design requirements after the project was started?

\begin{tabular}{|c|c|c|c|c|}
\hline & $\begin{array}{c}\text { No Changes } \\
\text { At All }\end{array}$ & $\begin{array}{l}\text { Moderate } \\
\text { Changes }\end{array}$ & & $\begin{array}{c}\text { Many } \\
\text { Changes }\end{array}$ \\
\hline $\mathrm{N}=20$ & $1(5.0 \%)$ & $9(45.0 \%)$ & $4(20.0 \%)$ & 0 \\
\hline
\end{tabular}

15. To what extent was the project cost impacted by changes in design requirements requested by the customer?

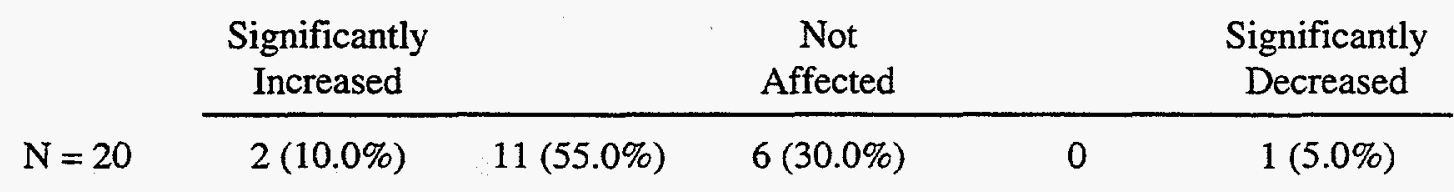


16. How satisfied were you with the extent to which you and your organization were involved in the design process?

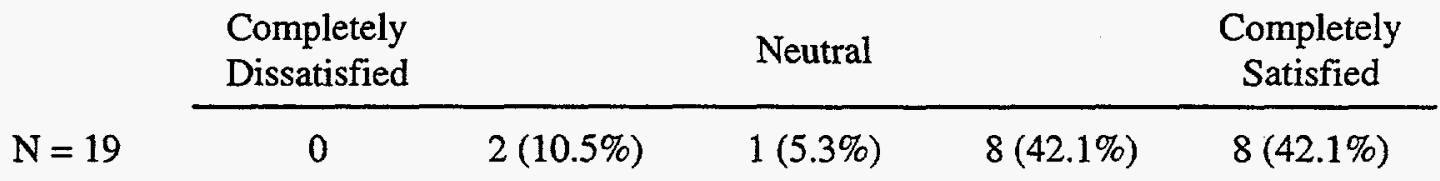

17. How satisfied was the customer with the extent to which the customer's organization was involved in the design process?

\begin{tabular}{|c|c|c|c|c|}
\hline & $\begin{array}{l}\text { Completely } \\
\text { Dissatisfied }\end{array}$ & Neutral & & $\begin{array}{l}\text { Completely } \\
\text { Satisfied }\end{array}$ \\
\hline$N=18$ & 0 & $5(27.8 \%)$ & $9(50.0 \%)$ & $4(22.2 \%)$ \\
\hline
\end{tabular}

\section{ES\&H Issues}

18. To what extent were construction ES\&H issues addressed in the design phase?

\begin{tabular}{|c|c|c|c|c|c|}
\hline & $\begin{array}{c}\text { Not Addressed } \\
\text { At All }\end{array}$ & & $\begin{array}{l}\text { Adequately } \\
\text { Addressed }\end{array}$ & & $\begin{array}{c}\text { Excessively } \\
\text { Addressed }\end{array}$ \\
\hline $\mathrm{J}=18$ & $1(5.6 \%)$ & $3(16.7 \%)$ & $11(61.1 \%)$ & $3(16.7 \%)$ & 0 \\
\hline
\end{tabular}

19. To what extent were the construction plans evaluated for compliance with OSHA standards?

\begin{tabular}{|c|c|c|c|c|c|}
\hline & $\begin{array}{c}\text { Not Evaluated } \\
\text { At All }\end{array}$ & & $\begin{array}{c}\text { Adequately } \\
\text { Evaluated }\end{array}$ & & $\begin{array}{c}\text { Excessively } \\
\text { Evaluated }\end{array}$ \\
\hline$N=16$ & $1(6.3 \%)$ & $3(18.8 \%)$ & $11(68.8 \%)$ & $1(6.3 \%)$ & 0 \\
\hline
\end{tabular}

20. During construction activities, did you notice representatives from any of the following groups performing ES\&H-oversight? Mark all that apply.

13 Construction Contractor's Safety Officer

3 ATLC (Union) Safety Representative

16 MK-Ferguson's ES\&H Representative

17 ORNL Safety and Health Evaluation and Support Team

7 ORNL Division for whom work was being performed

5 ORNL Safety Department

12 ORNL Radiological Protection

7 ORNL Environmental Compliance and Documentation

4 ORNL Engineering's Electrical Safety Engineering Group

7 ORNL Fire Protection Engineering

2 Office of Operational Readiness and Facility Safety

0 LMES Safety and Health Representative 

4 DOE-ORNL Site Office Facility
5 DOE-ORO ES\&H Representative
4 DOE-HQ Safety Representative
3 State of Tennessee ES\&H Representative
2 Other (See Comments for description)

21. How much ES\&H oversight was given to the project to manage the level of hazard on the project?

\begin{tabular}{cccccc} 
& $\begin{array}{c}\text { Totally } \\
\text { Insufficient }\end{array}$ & Just Right & $\begin{array}{c}\text { Totally } \\
\text { Excessive }\end{array}$ \\
\cline { 2 - 6 } $\mathrm{N}=17$ & 0 & 0 & $9(52.9 \%)$ & $4(23.5 \%)$ & $4(23.5 \%)$
\end{tabular}

22. To what extent did ES\&H oversight add value to the project?

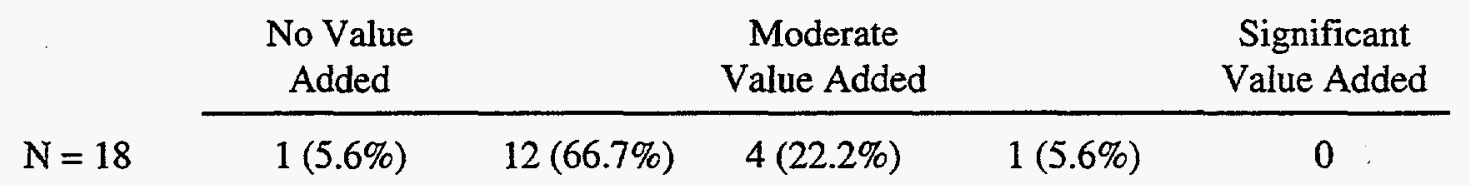

23. a) Were safety and health problems identified by ES\&H oversight?

\begin{tabular}{ccccc}
$N=17$ & $\begin{array}{c}\text { No } \\
\text { Findings }\end{array}$ & $\begin{array}{c}\text { Minor } \\
\text { Findings }\end{array}$ & $\begin{array}{c}\text { Moderate } \\
\text { Findings }\end{array}$ & $\begin{array}{c}\text { Serious } \\
\text { Findings }\end{array}$ \\
\cline { 2 - 5 } & $4(23.5 \%)$ & $13(76.5 \%)$ & 0 & 0
\end{tabular}

b) If problems were identified, were they corrected?
$\mathrm{N}=13$
$13(100 \%)$ Yes
0 No

24. To what extent was the schedule impacted by ES\&H oversight?

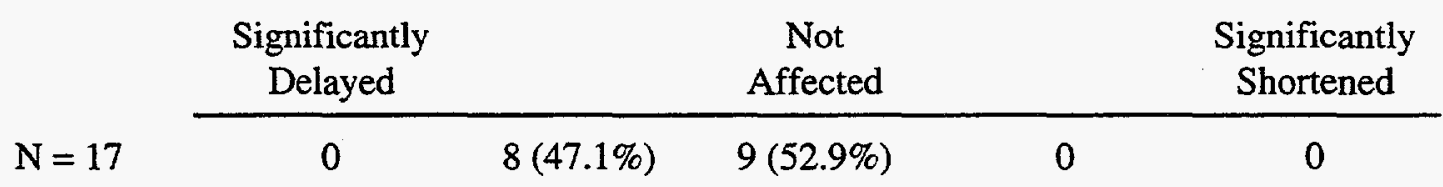

25. To what extent was the project cost impacted by ES\&H oversight?

\begin{tabular}{|c|c|c|c|c|c|}
\hline & $\begin{array}{c}\text { Significantly } \\
\text { Increased }\end{array}$ & & $\begin{array}{c}\text { Not } \\
\text { Affected }\end{array}$ & & $\begin{array}{c}\text { Significantly } \\
\text { Shortened }\end{array}$ \\
\hline $\mathrm{N}=17$ & 0 & $10(58.8 \%)$ & $7(41.2 \%)$ & 0 & 0 \\
\hline
\end{tabular}




\section{Maintenance and Construction Project Management}

28. Who has performed maintenance and construction work in your area? Mark all that apply and indicate the approximate percentage of all work that was done by each provider.

\begin{tabular}{rlc}
18 & MK-Ferguson (MK-F) & $\begin{array}{c}\text { Range of } \\
\text { Percentages }\end{array}$ \\
\cline { 3 - 3 } 19 & ORNL Plant and Equipment Division (P\&E) & $10-100$ \\
8 & Other (see Comments for descriptions) & $5-70$
\end{tabular}

29. How satisfied were you generally with the maintenance/construction provider(s)?
Completely Dissatisfied
Neutral
Completely Satisfied
a) $\mathrm{MK}-\mathrm{F}, \mathrm{N}=18$
$3(16.7 \%)$
$6(33.3 \%)$
$3(16.7 \%)$
$6(33.3 \%)$
0
b) P\&E, $N=18$
$5(27.8 \%)$
$5(27.8 \%)$
$8(44.4 \%)$
0
c) Other, $\mathrm{N}=8$
0
0
$2(25.0 \%) \quad 3(37.5 \%)$
$3(37.5 \%)$

30. How satisfied were you with the cost performance of the maintenance/construction provider(s)?
Completely
Dissatisfied
Neutral
Completely
$9(50.0 \%)$
$6(33.3 \%)$

0 Satisfied
a) $M K-F, N=18$
$4(21.1 \%)$
$8(42.1 \%)$
$4(21.1 \%)$
$3(16.7 \%)$
0
b) $P \& E, N=19$
$1(12.5 \%)$
2 (25.0\%)
2 (10.5\%)
$1(5.3 \%)$
c) Other, $N=8$
0
$3(37.5 \%)$
$2(25.0 \%)$

31. How satisfied were you with the schedule performance of the maintenance/construction provider(s)?
Completely
Dissatisfied
Neutral
Completely Satisfied
a) $\mathrm{MK}-\mathrm{F}, \mathrm{N}=18$
$2(11.1 \%)$
$9(50.0 \%)$
$4(22.2 \%)$
$3(16.7 \%)$
0
b) $P \& E, N=19$
3 (15.8\%)
$12(63.2 \%)$
$2(10.5 \%)$
2 (10.5\%)
0
c) Other, $N=8$
0
$1(12.5 \%)$
$2(25.0 \%)$
$2(25.0 \%)$
$3(37.5 \%)$ 
32. How satisfied were you with the quality of the final product(s)?

$\begin{array}{lccccc} & \begin{array}{c}\text { Completely } \\ \text { Dissatisfied }\end{array} & & \text { Neutral } & \text { Completely } \\ \text { Satisfied }\end{array}$

33. How accurately were costs tracked for the project(s)?

\begin{tabular}{lccccc} 
& $\begin{array}{c}\text { Very } \\
\text { Inaccurate }\end{array}$ & \multicolumn{3}{c}{$\begin{array}{c}\text { Moderately } \\
\text { Accurate }\end{array}$} & $\begin{array}{c}\text { Very } \\
\text { Accurate }\end{array}$ \\
\cline { 2 - 6 } a) $\mathrm{MK}-\mathrm{F}, \mathrm{N}=18$ & $2(11.1 \%)$ & $6(33.3 \%)$ & $5(27.8 \%)$ & $5(27.8 \%)$ & 0 \\
b) $\mathrm{P} \& \mathrm{E}, \mathrm{N}=19$ & $4(21.1 \%)$ & $5(26.3 \%)$ & $5(26.3 \%)$ & $4(21.1 \%)$ & $1(5.3 \%)$ \\
c) Other, $\mathrm{N}=7$ & 0 & 0 & $4(57.1 \%)$ & 0 & $3(42.9 \%)$
\end{tabular}

34. How accurately were costs charged for the project(s)?
Very
a) $\mathrm{MK}-\mathrm{F}, \mathrm{N}=15$
Inaccurate
b) $P \& E, N=17$
$1(6.7 \%)$
$1(6.7 \%)$
Moderately
Very
Accurate
Accurate
$9(60.0 \%) \quad 3(20.0 \%)$
$1(6.7 \%)$
c) Other, $\mathrm{N}=7$
$5(29.4 \%)$
$7(41.2 \%)$
$3(17.6 \%)$
2 (11.8\%)
$2(28.6 \%) \quad 1(14.3 \%)$
$4(57.1 \%)$

35. What was the level of productivity on your project(s)?

\begin{tabular}{lccccc} 
& $\begin{array}{c}\text { Very } \\
\text { Low }\end{array}$ & & Moderate & Very \\
a) MK-F, $\mathrm{N}=18$ & $3(16.7 \%)$ & $5(27.8 \%)$ & $9(50.0 \%)$ & $1(5.6 \%)$ & 0 \\
\cline { 2 - 6 } b) $\mathrm{P} \& \mathrm{E}, \mathrm{N}=19$ & $4(21.1 \%)$ & $7(36.8 \%)$ & $6(31.6 \%)$ & $2(10.5 \%)$ & 0 \\
c) Other, $\mathrm{N}=8$ & 0 & $1(12.5 \%)$ & $1(12.5 \%)$ & $4(50.0 \%)$ & $2(25.0 \%)$
\end{tabular}


36. How satisfied were you with the amount of time you had to spend initiating and following through on the project(s)?

\begin{tabular}{lccccc} 
& $\begin{array}{c}\text { Completely } \\
\text { Dissatisfied }\end{array}$ & & Neutral & Completely \\
a) $\mathrm{MK}-\mathrm{F}, \mathrm{N}=18$ & $1(5.6 \%)$ & $5(27.8 \%)$ & $10(55.6 \%)$ & $2(11.1 \%)$ & 0 \\
\cline { 2 - 6 } b) $\mathrm{P} \& \mathrm{E}, \mathrm{N}=19$ & $1(5.3 \%)$ & $8(42.1 \%)$ & $7(36.8 \%)$ & $1(5.3 \%)$ & $2(10.5 \%)$ \\
c) Other, $\mathrm{N}=8$ & 0 & 0 & $2(25.0 \%)$ & $3(37.5 \%)$ & $3(37.5 \%)$
\end{tabular}

37 How satisfied were you with the amount of time it took to begin the maintenance/construction work?

\begin{tabular}{lccccc} 
& $\begin{array}{c}\text { Completely } \\
\text { Dissatisfied }\end{array}$ & & Neutral & & $\begin{array}{c}\text { Completely } \\
\text { Satisfied }\end{array}$ \\
\cline { 2 - 6 } a) MK-F, $\mathrm{N}=18$ & $6(33.3 \%)$ & $7(38.9 \%)$ & $3(16.7 \%)$ & $1(5.6 \%)$ & $1(5.6 \%)$ \\
b) P\&E, $\mathrm{N}=19$ & $5(26.3 \%)$ & $7(36.8 \%)$ & $5(26.3 \%)$ & $1(5.3 \%)$ & $1(5.3 \%)$ \\
c) Other, $\mathrm{N}=8$ & .0 & $2(25.0 \%)$ & $2(25.0 \%)$ & $2(25.0 \%)$ & $2(25.0 \%)$
\end{tabular}

38. How satisfied were you with the amount of time it took to complete the whole maintenance/construction process?

\begin{tabular}{lccccc} 
& $\begin{array}{c}\text { Completely } \\
\text { Dissatisfied }\end{array}$ & & Neutral & & $\begin{array}{c}\text { Completely } \\
\text { Satisfied }\end{array}$ \\
\cline { 2 - 6 } a) MK-F, N =18 & $2(11.1 \%)$ & $10(55.6 \%)$ & $3(16.7 \%)$ & $2(11.1 \%)$ & $1(5.6 \%)$ \\
b) P\&E, $\mathrm{N}=19$ & $2(10.5 \%)$ & $8(42.1 \%)$ & $6(31.6 \%)$ & $2(10.5 \%)$ & $1(5.3 \%)$ \\
c) Other, $\mathrm{N}=8$ & 0 & $1(12.5 \%)$ & $3(37.5 \%)$ & $2(25.0 \%)$ & $2(25.0 \%)$
\end{tabular}

39. For each of the project sizes shown below, who do you feel is best qualified to perform maintenance/construction activities at ORNL? Mark only one provider within each size category.
a) $<\$ 100 \mathrm{~K}, \mathrm{~N}=19$
b) $\$ 100 \mathrm{~K}$ to $<\$ 350 \mathrm{~K}, \mathrm{~N}=18$
$4(22.2 \%)$
c) $\$ 350 \mathrm{~K}$ to $<\$ 2 \mathrm{M}, \mathrm{N}=18$
$7(38.9 \%)$
d) $\$ 2 \mathrm{M}, \mathrm{N}=18$
5 (27.8\%)
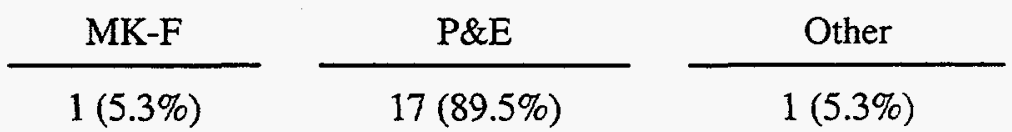

7 (38.9\%)

7 (38.9\%)

$2(11.1 \%)$

$9(50.0 \%)$

$2(11.1 \%)$

$11(61.1 \%)$ 
40. For each of the project sizes shown below, which provider do you prefer for performing maintenance/ construction activities at ORNL? Mark only one provider within each size category. Please explain.
a) $<\$ 100 \mathrm{~K}, \mathrm{~N}=19$
b) $\$ 100 \mathrm{~K}$ to $<\$ 350 \mathrm{~K}, \mathrm{~N}=18$
c) $\$ 350 \mathrm{~K}$ to $<\$ 2 \mathrm{M}, \mathrm{N}=18$
d) $\$ 2 \mathrm{M}, \mathrm{N}=18$
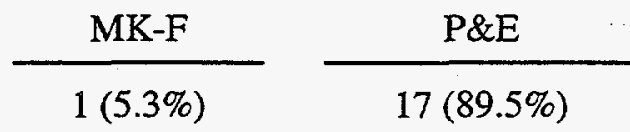

4 (22.2\%)

7 (38.9\%)

7 (38.9\%)

$6(33.3 \%)$

$3(16.7 \%)$

$9(50.0 \%)$

$5(27.8 \%)$

$2(11.1 \%)$

$11(61.1 \%)$

\section{Labor Standards Reviews}

41. Have you been involved in any Labor Standards reviews or issues (Davis-Bacon Act or Service Contract Act)? If yes, please complete the rest of the survey. If no, proceed to Question 49.

$$
\mathrm{N}=19 \quad 16(84.2 \%) \text { Yes } 3(15.8 \%) \text { No }
$$

\begin{tabular}{|c|c|c|c|c|c|}
\hline & $\begin{array}{c}\text { Less than } \\
1 \text { week }\end{array}$ & $\begin{array}{c}1-2 \\
\text { weeks }\end{array}$ & $\begin{array}{c}2-3 \\
\text { weeks }\end{array}$ & $\begin{array}{c}3-4 \\
\text { weeks }\end{array}$ & $\begin{array}{c}\text { More than } \\
4 \text { weeks }\end{array}$ \\
\hline$J=16$ & 0 & $1(6.3 \%)$ & $5(31.3 \%)$ & $7(43.8 \%)$ & $3(18.8 \%)$ \\
\hline
\end{tabular}

42. How much time is required for a typical Labor Standards review?

43. To what extent did the time required for Labor Standards rulings impact the schedule of a typical project?

\begin{tabular}{|c|c|c|c|c|c|}
\hline & 1 time & 2 times & 3 times & 4 times & $>4$ times \\
\hline$N=14$ & $3(21.4 \%)$ & $5(35.7 \%)$ & $5(35.7 \%)$ & 0 & $1(7.1 \%)$ \\
\hline
\end{tabular}

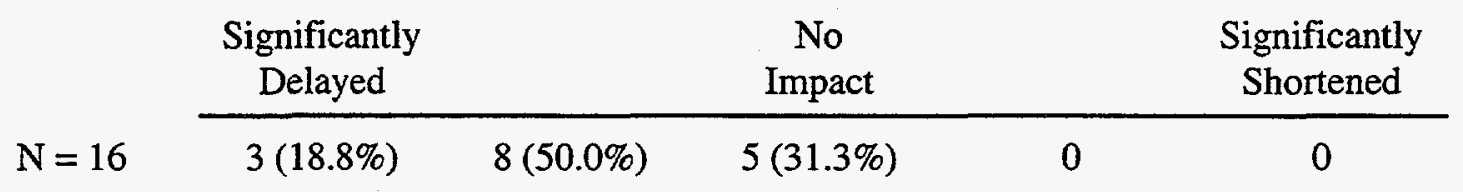

44. On a typical project, how often do you have to interact with Labor Standards to receive a ruling? 
45. In a typical project, which of the following was the most common reason for interacting with Labor Standards?

$$
\begin{array}{ll}
\mathrm{N}= & 16 \\
8(50.0 \%) & \text { Insufficient information } \\
0 & \text { Incorrectly filled out forms } \\
0 & \text { Incorrect job description } \\
5(31.3 \%) & \text { Disagreement about ruling } \\
3(18.8 \%) & \text { Other (See Comments for descriptions) }
\end{array}
$$

\begin{tabular}{|c|c|c|c|c|c|}
\hline & None & & Half & & All \\
\hline$N=13$ & 0 & $4(30.8 \%)$ & $5(38.5 \%)$ & $4(30.8 \%)$ & 0 \\
\hline
\end{tabular}

\begin{tabular}{|c|c|c|c|c|}
\hline & $\begin{array}{c}\text { Not Consistent } \\
\text { At All }\end{array}$ & & $\begin{array}{l}\text { Reasonably } \\
\text { Consistent }\end{array}$ & $\begin{array}{c}\text { Very } \\
\text { Consistent }\end{array}$ \\
\hline$N=14$ & $3(21.4 \%)$ & $2(14.3 \%)$ & $7(50.0 \%)$ & $1(7.1 \%)$ \\
\hline
\end{tabular}

46. How many requests for ruling go through without a problem?

\begin{tabular}{|c|c|c|c|c|c|}
\hline & $\begin{array}{c}\text { Totally } \\
\text { Insufficient }\end{array}$ & & Just Right & & $\begin{array}{c}\text { Totally } \\
\text { Excessive }\end{array}$ \\
\hline $\mathrm{N}=19$ & 0 & $4(21.1 \%)$ & $9(47.4 \%)$ & $6(31.6 \%)$ & 0 \\
\hline
\end{tabular}

47. How consistent have the Labor Standards been for similar projects?

\section{General}

49. In general, how much project planning was performed on the project?

53. What experience did you base your survey responses on?

$\mathrm{N}=19$\begin{tabular}{c}
$\begin{array}{c}\text { All what } \\
\text { I've heard }\end{array}$ \\
\cline { 2 - 5 }
\end{tabular}


Note: For "mark-all-that-apply" questions, the number of times a choice was marked is shown in the "Yes \#" column. No percentages are shown for these questions.

\begin{tabular}{|c|c|c|c|c|c|}
\hline \multicolumn{6}{|l|}{ Engineering Design and Construction Process Survey } \\
\hline \multicolumn{6}{|c|}{ Summary of Yes/No Responses from Project Engineers and Managers } \\
\hline & & \multicolumn{2}{|c|}{ Yes } & \multicolumn{2}{|c|}{ No } \\
\hline Question & $\mathbf{N}$ & $\#$ & $\%$ & $\#$ & $\%$ \\
\hline \multicolumn{6}{|l|}{ Design and Construction Risk } \\
\hline \multicolumn{6}{|l|}{ Systems Requirements Document } \\
\hline $\begin{array}{l}\text { 1a. Did you participate in the development of a Systems Requirements } \\
\text { Document for this project? }\end{array}$ & 20 & 13 & 65.0 & 7 & 35.0 \\
\hline $\begin{array}{l}\text { 1b. Did anyone else from your organization participate in the development of } \\
\text { a Systems Requirements Document for this project? }\end{array}$ & 20 & 15 & 75.0 & 5 & 25.0 \\
\hline \multicolumn{6}{|l|}{$\begin{array}{l}\text { 1c. If someone else did participate, at what level did this participation occur? } \\
\text { Mark all that apply. }\end{array}$} \\
\hline Division Director & & 1 & & & \\
\hline Section Head & & 2 & & & \\
\hline Group Leader & & 4 & & & \\
\hline Other & & 8 & & & \\
\hline $\begin{array}{l}\text { 1d. Was the customer involved in the development of a Systems } \\
\text { Requirements Document for this project? }\end{array}$ & 20 & 17 & 85.0 & 3 & 15.0 \\
\hline \multicolumn{6}{|l|}{$\begin{array}{l}\text { 5a. Who reviewed the Systems Requirements Document? Mark all that } \\
\text { apply. }\end{array}$} \\
\hline Engineering Division Director & & 1 & & & \\
\hline Engineering Section Head & & 3 & & & \\
\hline Engineering Group Leader & & 9 & & & \\
\hline Customer's Division ES\&H Officer & & 5 & & & \\
\hline Customer's Line Organization & & 11 & & & \\
\hline Other & & 9 & & & \\
\hline \multicolumn{6}{|l|}{$\begin{array}{l}\text { 5b. Who approved the Systems Requirements Document? Mark all that } \\
\text { apply. }\end{array}$} \\
\hline Engineering Division Director & & 2 & & & \\
\hline Engineering Section Head & & 3 & & & \\
\hline Engineering Group Leader & & 7 & & & \\
\hline Customer's Division ES\&H Officer & & 2 & & & \\
\hline Customer's Line Organization & & 12 & & & \\
\hline Other & & 7 & & & \\
\hline \multicolumn{6}{|l|}{ ES\&H Issues } \\
\hline \multicolumn{6}{|l|}{$\begin{array}{l}\text { 20. During construction activities, did you notice representatives from any of } \\
\text { the following groups performing ES\&H oversight? Mark all that apply. }\end{array}$} \\
\hline Construction Contractor's Safety Officer & & 13 & & & \\
\hline ATLC (Union) Safety Representative & & 3 & & & \\
\hline MK-Ferguson ES\&H Representative & & 16 & & & \\
\hline ORNL Safety and Health Evaluation and Support Team & & 17 & & & \\
\hline
\end{tabular}




\begin{tabular}{|c|c|c|c|c|c|}
\hline ORNL Division for whom work was being performed & & 7 & & & \\
\hline ORNL Safety Department & & 5 & & & \\
\hline ORNL Radiological Protection & & 12 & & & \\
\hline ORNL Environmental Compliance and Documentation & & 7 & & & \\
\hline ORNL Engineering's Electrical Safety Engineering Group & & 4 & & & \\
\hline ORNL Fire Protection Engineering & & 7 & & & \\
\hline Office of Operational Readiness and Facility Safety & & 2 & & & \\
\hline LMES Safety and Health Representative & & 0 & & & \\
\hline DOE-ORNL Site Office Facility & & 4 & & & \\
\hline DOE-ORO ES\&H Representative & & 5 & & & \\
\hline DOE-HQ Safety Representative & & 4 & & & \\
\hline State of Tennessee ES\&H Representative & & 3 & & & \\
\hline Other & & 2 & & & \\
\hline $\begin{array}{l}\text { 23b. Were safety and health problems identified by ES\&H oversight } \\
\text { corrected? }\end{array}$ & 13 & 13 & 100.0 & 0 & 0.0 \\
\hline \multicolumn{6}{|l|}{ Maintenance and Construction Project Management } \\
\hline \multicolumn{6}{|l|}{$\begin{array}{l}\text { 28. Who has performed maintenance and construction work in your area? } \\
\text { Mark all that apply. }\end{array}$} \\
\hline MK-Ferguson & & 18 & & & \\
\hline P\&E & & 19 & & & \\
\hline Other & & 8 & & & \\
\hline \multicolumn{6}{|l|}{ Labor Standards Reviews } \\
\hline $\begin{array}{l}\text { 41. Have you been involved in any Labor Standards reviews or issues } \\
\text { (Davis-Bacon or Service Contract Act)? }\end{array}$ & 19 & 16 & 84.2 & 3 & 15.8 \\
\hline
\end{tabular}

\section{C.1.2.4 Written Comments by Project Engineers and Managers}

Refer to identification numbers at the end of the section to determine which groups the numbers on the left designate.

1c. "Other" participants who participated in the development of a Systems Requirements Document for this project.

1 REDs

4 Lead Engineer

5 Principal Engineer

8 Project Engineer

10 Project Engineer

12 Project Manager

15 Principal Engineer

18 Project Engineer 
3. How much effort was made during preparation of the Systems Requirements Document to manage the marginal cost risk associated with the project?

15 Assuming this is project contingency, the better the requirements are defined, the smaller the contingency can be.

4. How much effort was made during preparation of the Systems Requirements Document to manage the complexity of the project?

15 In general, GPPs are not very complex.

5. "Other" personnel who reviewed and/or approved the Systems Requirements Document.

1 DOE (reviewed and approved)

2 Team members (reviewed), DOE (reviewed)

3 PJ (reviewed and approved), Customer (reviewed and approved)

5 Engineering Project Manager (reviewed and approved), Principal Engineer (reviewed and approved)

8 Project Engineer (reviewed)

10 Project Engineer (reviewed and approved)

15 Engineering Project Manager (approved)

6. Who performed the design phase of the project?

15 Used an existing building design; site design done in-house.

17 Our group

$19 \mathrm{M} \& \mathrm{C}$ and ETD

8. How satisfied were you with the work performed by the design organization?

15 Depends on the discipline.

9. How much effort was made during the design phase to manage the ES\&H risk associated with the project?

15 Did what was required.

11. How much effort was made during the design phase to manage the complexity of the project?

15 Site design is not very complex.

12. During the design phase, how involved was the future operating staff in reviewing the risk associated with operating the facility, equipment, or process following construction?

15 These were office buildings of simple design. 
13. During the design phase, how much consideration was given to the cost of operating the completed project?

15 Construction cost was the overriding factor. However, building systems selected were supported by a life cycle cost. The answers were obvious but required excessive analysis to prove.

17. How satisfied was the customer with the extent to which the customer's organization was involved in the design process?

15 They probably were not very happy. We used an existing building design, and they had little opportunity to modify it.

20. "Other" representatives who performed ES\&H oversight during construction activities.

13 TDEC-UST Division representative

20 TDEC

21. How much ES\&H oversight was given to the project to manage the level of hazard on the project?

15 It fluctuated. Toward the end it had reached a reasonable level.

24. To what extent was the schedule impacted by ES\&H oversight?

15 Indirect cost. Contractors tend to stop work when observers are on the job site.

26. What are the barriers to accepting appropriate levels of project risk?

1 - Numerous organizations that have to understand and accept risk. $\bullet$ Difficulty in quantifying risk to be accepted.

2 A zero tolerance approach has impacted cost and schedule.

3 - Overreaction to minor safety violations (stopping work on all projects when one project has a safety problem). - Desire to have zero risk during construction, which is impossible.

5 DOE overkill; one job can affect entire Reservation.

6 Attitudes by various management and support organizations that we must go overboard in anticipating any possible "bad thing" that can happen during a project, no matter how low the probability of occurrence, and doing everything possible to prevent each bad thing. Also, management tends to make individuals risk-averse by looking for scapegoats upon discovery of a problem.

7 Job security. Lack of DOE-ORO support. Low reward-to-risk ratio.

8 Responsibility is not given completely to the project manager. Too many groups, organizations, and individuals can cause delays or bring work to a halt. Everyone has to be made happy. This costs money/time.

9 Management overreaction to minor events leads to an ultra-conservative approach aimed at avoiding any problems.

10 Difficulty in applying graded risk levels since most participants seem to seek the comfort of a very conservative approach to risk.

11 Mentality which will accept $N O$ risk.

12 - Fear of consequences for something going wrong. - Inflexibility of choice for method of accomplishment for design and construction. $\bullet$ DOE. 
13 Individual's resistance to using their judgement to interpret vague rules to the advantage of the Lab and the project. ("The book says...")

14 Lack of expertise in analyzing risk.

15 The inability of oversight organizations to accept the fact that some risks are inherent in construction. Accidents will happen and can actually be aggravated by too much interference. There are organizations that are experts in their field and are hindered from doing their work in ways they have demonstrated to be safe over years of activities.

16 Empires which people have built for themselves.

19 The Laboratory.

20 A failure by ORNL and LMES management to understand that in order to compete in the real world, a certain amount of risk must be accepted.

27. In what areas does ORNL do very well at accepting appropriate levels of project risk?

1 Seems like acceptance of risk is easier for R\&D and waste management operations than for construction-type activities.

2 Radiation control.

3 Health physics, respiratory protection.

5 None identified.

7 On compliance-type jobs or $\mathrm{DOE} /$ management-mandated jobs, there is usually a greater support for accepting risks.

8 I cannot think of any area. Everything is too conservative.

13 Overall, none.

14 Making good progress in using risk analysis to prioritize projects by need.

15 It's getting better.

16 In research.

19 None.

20 We are doing better at evaluating project risk on infrastructure projects (particularly utilities related) because of involvement by the customer and the need to prioritize work to get the biggest "bang" for our dollars.

28. "Other" providers who have performed maintenance and construction work in your area.

3 Service contract

6 FPSC to MK-F

7 Service contractors

8 Subcontractors (may be MK-F subcontractor)

16 Service subcontractors

17 I\&C

20 Service subs

29. How satisfied were you generally with the maintenance/construction provider(s)?

15 P\&E: depends on the craft.

30. How satisfied were you with the cost performance of the maintenance/construction provider(s)?

15 MK-F: overhead cost way too high. P\&E: can't control their cost. 
36. How satisfied were you with the amount of time you had to spend initiating and following through on the project(s)?

15 Happens to be one of the things I like to do.

40. Which provider do you prefer for performing maintenance/construction activities at ORNL?

1 P\&E advantage is ease of getting work going. They do well on small, short-duration jobs. MK-F takes longer to get going but does better managing, so they are cost-effective for larger jobs.

43. To what extent did the time required for Labor Standards rulings impact the schedule of a typical project?

15 Done very early in the process on construction jobs.

44. On a typical project, how often do you have to interact with Labor Standards to receive a ruling?

15 Other than preparing the documents, I seldom interface directly with the process.

46. How many requests for ruling go through without a problem?

15 Depends on the request. Construction requests won't be challenged. Nearly all others will.

48. If you could start with a "clean sheet," what would your process be for determining whether a job is construction work as defined by the Davis-Bacon Act or service work as defined by the Service Contract Act?

1 Compare project activities with requirements of each act and decide accordingly.

2 I would like to see written criteria where judgements could be more defined.

3 I would not differentiate between construction work and service work. I would simply determine the most cost-effective MOA for the particular project and select accordingly. To ensure compliance with Davis-Bacon, I would require Davis-Bacon wages be paid to the labor involved in the project. This would do away with the need for Davis-Bacon review and reduce project schedule and cost.

5 One expert would provide guidance whenever needed. Conversations with expert would alleviate surprises and need to replan/repackage work.

7 First, I would establish a higher limit (say $\$ 200,000$ ) versus the current limit of $\$ 2,000$. Next, I would like the process to put an emphasis on the cost-effectiveness and value-added, rather than just blind ruling based on partisan politics.

8 Disband the Labor Standards Board. Determining whether work is construction or service is a clerical function which should be performed in less than five minutes by a competent person. At Oak Ridge this process is completely political and goes way beyond the intent of the DavisBacon Act and Service Contract Act. Individuals either in P\&E or Engineering should make determination with appropriate documentation for review by DOE/DOL if necessary.

11 Default would be P\&E doing the work. ORNL to decide if/when to use service or construction contractors depending on work scope.

12 ORNL committee consisting of P\&E, Engineering and Construction, and other appointed members. Little or no DOE involvement. 
13 Service work - work performed by a company that does a specialty type of work that "construction" companies would have to subcontract for. Construction work - work that covers demolition, clearing, site preparation, installation of services and equipment, and associated clean up.

14 Consider the operational interfaces and need for scheduling the work; contract as much work on a bid basis as possible when operational interfaces are not significant; select potential bidders based on the expertise required and the need for competition; use P\&E forces for all tie-ins.

15 Informal to ORNL. Go to DOE only on an exception basis.

16 Make own decision and be audited quarterly by DOE or DOL.

17 I don't have enough knowledge of these Acts to make a judgement.

20 We need a consistent, accepted definition of what construction is and general dollar guidelines. The customer/initiator then makes the labor standards ruling on his own with formal reviews.

50. If you could start with a "clean sheet," what would you like to have as ORNL's new Engineering Design and Construction Process?

1 - Define requirements and obtain customer approval. - Design using appropriate organization. - Construct using appropriate organization. - Confirm completion of design requirements and turn over to customer.

2 Greater flexibility in selecting design and construction firms.

3 I would allow more flexibility in MOA for design and construction. Since each project is unique, having the ability to choose how the design and construction are completed would greatly improve our ability to provide cost-effective services. Being locked into a particular MOA also reduces the incentive of the various parties to be competitive, since they don't have any competition for work.

5 ORNL Engineering and Construction Management Division would have the lead role and have more flexibility and control in selecting participants and methods of accomplishment. A/E firms would be selected and managed by ORNL—not DOE.

6 Need identified $\rightarrow$ Client drafts mission statement $\rightarrow$ Engineering works with client to refine mission statement and prepare systems requirements document $\rightarrow$ Engineering uses systems requirements to prepare RFP or bid package $\rightarrow$ Responses evaluated and work is awarded $\rightarrow$ Engineering holds PDR and CDR (pre-design and critical design review) $\rightarrow$ Engineering approves design and construction RFP prepared (if separate activity)

7 - Close partnering with customer divisions and ES\&H groups. - Better, faster, responsive system to initiate work (project) as compared to our current ESO system. • More "can do" type help from ES\&H, etc., groups. • Use the commercial approach "bottom line counts."

8 Divisions would have Engineering representatives to support their requirements in defining requirements and planning engineering design/construction projects. The best design approach would be determined by the ORNL Engineering Director in conjunction with customer requirements. The A/E design contracts would be performed/managed by ORNL Engineering to maintain consistency for ORNL. Construction contracts would be awarded by ORNL procurement/contracts and managed by ORNL Engineering and Construction Management Division. The ORNL Engineering Project Managers would form tight bonded teams with the customer divisions and ES\&H organizations to ensure the best construction products were received with least disruption to the contractor.

9 More control by the project manager, who is providing the funding, of the resources utilized. This would require giving him the ability to choose, with more flexibility than is currently available, the organizations that perform the work. Funding, or at least future work, could then be more closely tied to performance. 
11 ORNL to manage its own engineering and construction activities. Solicit A/E for design or perform in-house. Solicit FPCC for construction. Provide construction management and oversight with in-house staff or subcontract for these services.

12 Design: total flexibility to choose the most cost-effective method of accomplishment. Construction: ORNL Engineering and Construction management of projects in the small- and medium-dollar range. A choice of directly managing or hiring a construction manager to manage large jobs.

13 ORNL design should be provided by a team (LMER/LMES) or a company (subcontractor) as designated by the project manager. This decision would be based on the estimated cost of the project and the complexity of the project. - ORNL construction should be provided by a company (on-site = Oak Ridge) under a required "Task" release effort for small- and mediumsized projects. Larger projects should be subcontracted by ORNL Engineering and Construction Management Division. - Integration of design and construction would be a function of ORNL Engineering and Construction Management Division.

14 A team of specialists with experience in project design and management to oversee the project from requirements phase to project completion and closeout.

15 Needs to be graded. One size doesn't fit all.

16 Independence to get the job done safely, cost-effectively, and on schedule. Be told to get results, but not told how to do the job and the ??? for results.

20 Simpler, more customer focused. They are a service organization and should present themselves that way. They don't lead a process-they are there to help the customer through a project.

51. What advice would you give to the Engineering Design and Construction Reengineering Team?

1 - Need to overhaul requirements to use existing inefficient system (CM, AE, etc.). Give PM opportunity to use what makes sense. - Need to approach projects with hard-nosed business attitude. Maintain discipline (i.e., resist changes unless critical). Rigorous configuration management and change control. - Eliminate "political" aspects of system (labor agreement, preferred ORNL divisions, etc.).

2 Create a system that allows true competition with regard to selecting design and construction resources.

3 Look into giving more flexibility to the project engineer. Also reduce safety requirements to those found in outside industry, where appropriate.

4 - The ES\&H, Safety, Health Physics, etc., and customers do not spend the time necessary to review the design. They never have time. Instead they try to change things in the field. $\bullet$ Projects should be managed by the project managers. They need costs on a weekly basis and the ability to stop individuals from charging their work orders. - Time should be taken to develop the systems requirements document and get approval and buy-in from all participants at a meeting, not just signatures on the page. Need to use systems approach. $\bullet P \& E$ does not have the experience or motivation or supervision to do construction. They should be used strictly for maintenance. We should use fixed-price outside contractors managed by ORNL Engineering in the field. MK-F is too expensive. $\bullet$ ORNL should increase the radiation dose limits up to the DOE maximum. - Hoisting and rigging regulations and fall protection regulations at ORNL should be reduced to industry standards. - The Necessary and Sufficient effort is going well. National ASME, IEEE, etc., standards should be used instead of DOE orders.

5 - Work to provide more control and responsibility by ORNL side of DOE than Engineering group at DOE. Take control of Davis-Bacon process, which is currently driving up costs. Continue to reduce risks/negative consequences for occasional project failure (cost, schedule, ES\&H), otherwise excessive conservatism will continue with resulting high costs and long 
schedules. Benchmark for project success and ES\&H requirements/results should be the commercial sector, not DOE. - Do not permit individual divisions to take control of their drawings, engineering and construction activities. Otherwise expect chaos. - There is a need to improve as-constructed drawing for ORNL, especially atlas. Provide funding for effort.

6 - Eliminate all existing Engineering/Construction procedures. - Use functional analysis to define new process. $\bullet$ Prepare streamlined, effective procedures for doing business in accordance with the new process.

7 Be cost-effective, customer focused.

8 Focus more on how Engineering Design and Construction functions are performed within divisions. There may be too much duplication of effort within divisions in this functional area. This has caused delays in getting work accomplished in a cost-effective and time-efficient manner. Some divisions need engineering capability to carry out operational requirements, but other functions are overstaffed, which causes division overheads to be too high. If ORNL is to be competitive, these excesses in staffing need to be addressed/reviewed.

10 - To the extent practical, approach the reengineering effort from a "clean sheet" perspective.

- Suppress the tendency to overemphasize reporting and "control." It seems to be easy to confuse "control" as being the total management function. - Build in a workable avenue for getting routine relief from policies/procedures/regulations that really do not apply as intended.

12 Choose methods/processes that will be the most cost-effective and efficient for the Laboratory as recommendations.

13 Provide the best service to the customer by initiating early dialogue, providing continual involvement in project decisions, providing regular cost/schedule feedback, and periodic project evaluations.

14 Work closely with the client; understand the technical requirements and work to achieve the most cost-effective method of accomplishment possible to meet key requirements with quality appropriate for the type of facility.

15 - Look at all of the documents required during project planning and execution and determine which add value and which are done for the purpose of putting a check in the box. $\bullet$ Recognize that conceptual estimates are just that. Don't try to count pieces for a design that doesn't exist. - Establish a small team with broad background that can do an early review to identify projects that have ES\&H implications. Don't burden the rest of the projects with all the rest of the "novalue-added" stuff.

16 Be honest.

19 Find a way to allow inside workers (machinists, electricians, etc.) work at a fixed cost. I don't care if it's at a higher rate. We just need a guarantee that we will get a product for the money spent. Projects can't afford to pay for work two or three times.

52. Please write in any other comments you have about your experience with maintenance or construction projects at ORNL.

1 Generally mixed bag-some projects have been easy and worked well; others have been very difficult. Major source of problems on my projects has been change in direction from DOE forced by regulators' inability to make decision. Once decision is made and holds, implementation is accomplished with differing levels of success and efficiency depending on organizations involved.

2 The project manager needs more control over support organizations to maximize cost control and ensure schedule success. Often, support groups "don't work for you" and can be less responsive than they should be.

3 Good people trying to work with a bad system! 
5 - A separate construction manager is probably not needed. Engineering and Construction Management Division could gear up to provide that service at a reduced cost while improving coordination. - Improvements in P\&E support for projects is urgently needed. P\&E do quality work but do not meet schedules or cost estimates. No one person is in charge/responsible for support to any one project. Union rules and poor work ethic are responsible. $\bullet$ Cost system is inadequate for project management control.

6 The ORNL organizational structure which must be interfaced with is overly complex and convoluted.

12 - MK cost averages $25-40 \%$. Typical commercial construction management cost is 4-10\%.

- Many functions have duplication of effort. - Accommodation of construction activities is not easily obtained with most facility managers. Construction is often considered an aggravation/irritation. - Thorough planning with customer involvement eliminates many problems.

13 Maintenance support is effective if the plant management will provide the level of funding to support keeping the plant buildings and services up to par. When maintenance personnel are not used effectively, they tend to believe construction activities are maintenance. A strong maintenance program would help this. Construction at ORNL seems to be clearly defined relative to maintenance.

14 The current method is too costly. DOE needs to accept the need for using industry standards, including NRC for nuclear facilities. MK-F is too costly, with not enough value added. P\&E has good crafts personnel but does not know how to manage project work and is not sensitive to cost and schedule. Engineering is making progress in reducing cost and needs to continue efforts to streamline. It would be a mistake to let each division manage construction projects.

16 Have had some outstanding results.

19 Some good, some bad. It really depends on the worker. If steps are taken to identify good workers and eliminate the others, that would be a step in the right direction.

\section{Identification}

\begin{tabular}{|c|c|c|c|}
\hline ID & Organization $^{a}$ & Project size & Responses based on ${ }^{b}$ \\
\hline 1 & ORNL ECMD & $\$ 2 \mathrm{M}$ & Direct/Heard \\
\hline 2 & & $\$ 350 \mathrm{~K}$ to $<\$ 2 \mathrm{M}$ & Equal \\
\hline 3 & & $\$ 350 \mathrm{~K}$ to $<\$ 2 \mathrm{M}$ & Direct/Heard \\
\hline 4 & & $\$ 2 M$ & Direct \\
\hline 5 & & $\$ 2 \mathrm{M}$ & Direct \\
\hline 6 & & $\$ 350 \mathrm{~K}$ to $<\$ 2 \mathrm{M}$ & Direct \\
\hline 7 & & $\$ 350 \mathrm{~K}$ to $<\$ 2 \mathrm{M}$ & Direct/Heard \\
\hline 8 & ORNL ECMD & $\$ 2 \mathrm{M}$ & Direct/Heard \\
\hline 9 & & $\$ 350 \mathrm{~K}$ to $<\$ 2 \mathrm{M}$ & Equal \\
\hline 10 & & $\$ 2 M$ & Direct \\
\hline 11 & & Unspecified & Unspecified \\
\hline 12 & & $\$ 350 \mathrm{~K}$ to $<\$ 2 \mathrm{M}$ & Equal \\
\hline
\end{tabular}




\begin{tabular}{llll} 
ID & Organization $^{a}$ & \multicolumn{1}{c}{ Project size $^{\text {Responses based on }}{ }^{b}$} \\
\hline 13 & $\$ 100 \mathrm{~K}$ to $<\$ 350 \mathrm{~K}$ & Direct/Heard \\
14 & $\$ 2 \mathrm{M}$ & Equal \\
15 & $\$ 350 \mathrm{~K}$ to $<\$ 2 \mathrm{M}$ & Direct \\
16 & Unspecified & Direct \\
17 & ETD & $\$ 100 \mathrm{~K}$ to $<\$ 350 \mathrm{~K}$ & Direct/Heard \\
18 & & $\$ 100 \mathrm{~K}$ to $<\$ 350 \mathrm{~K}$ & Equal \\
19 & & $\$ 350 \mathrm{~K}$ to $<\$ 2 \mathrm{M}$ & Direct \\
20 & Unspecified Direct/Heard & \\
\hline
\end{tabular}

${ }^{a} \mathrm{E} \& \mathrm{CM}=$ Engineering and Construction Management Division, ETD = Engineering Technology Division.

${ }^{b}$ Heard $=$ entirely what $I$ have heard from others; Heard/Direct $=$ more what $I$ have heard from others rather than direct, personal experience; Equal = equal mix of personal experience and what I've heard from others; Direct/Heard = more direct, personal experience rather than what I have heard from others; and Direct $=$ entirely on direct, personal experience.

\section{C.1.2.5 Summary of Responses from ES\&H Personnel}

For each question, the number and percentage of respondents who selected a particular answer are shown in front of or below that answer, depending on the format of the question. Note that the percentage is calculated from the total number of respondents who answered the question after the "Don't Know/Not Applicable/No Opinion" responses were excluded. The total number of respondents is shown at the left margin. No percentages are shown for the "mark-all-that-apply" questions. There were 7 respondents to this survey.

Size of the project referred to:

0 Less than $\$ 100 \mathrm{~K}$

0 Greater than or equal to $\$ 100 \mathrm{~K}$ but less than $\$ 350 \mathrm{~K}$

5 Greater than or equal to $\$ 350 \mathrm{~K}$ but less than $\$ 2 \mathrm{M}$

1 Greater than or equal to $\$ 2 \mathrm{M}$

\section{Systems Requirements Document}

1. a) Did any ES\&H personnel participate in the development of a Systems Requirements Document for this project?
$N=5$
$3(60.0 \%)$ Yes
$2(40.0 \%)$ No

b) If someone did participate, at what level did this participation occur? Mark all that apply.

0 Division Director

0 Section Head

2 Group Leader

2 Other (See Comments for description) 
2. How much effort was made during preparation of the Systems Requirements Document to manage the ES\&H risk associated with the project?

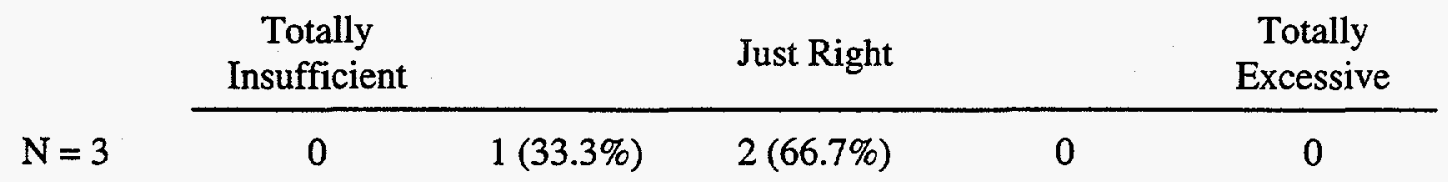

3. Who in your organization reviewed and/or approved the Systems Requirements Document? Mark all that apply.

Division director

Section head

Group leader

Other (see Comments for descriptions)

$\begin{array}{cc}\text { Reviewed } & \text { Approved } \\ 0 & 0 \\ 0 & 0 \\ 2 & 0 \\ 3 & 0\end{array}$

\section{Project Design}

4. Who performed the design phase of the project?
4 LMES/LMER Engineering
1 Outside engineering firm
2 Unspecified

5. To what extent were you or your organization involved in the selection of the design organization?

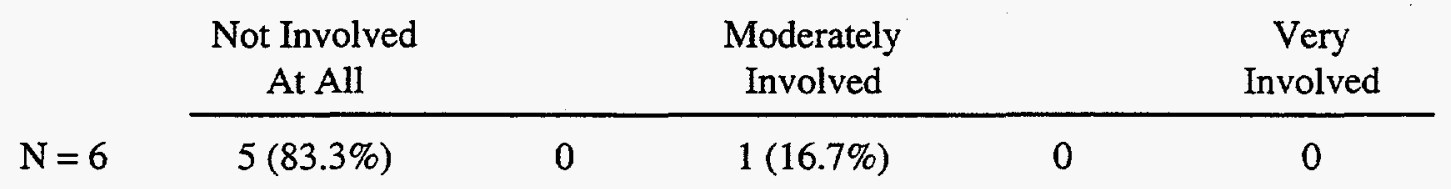

6. To what extent did the design organization consult with you or your organization during the design phase of the project?

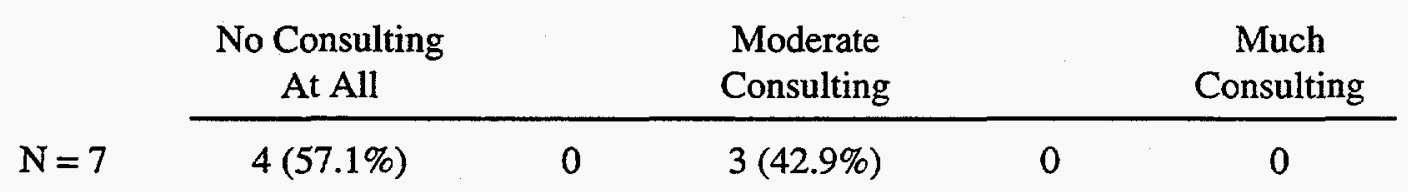


7. How satisfied were you with the extent to which you and your organization were involved in the design process?

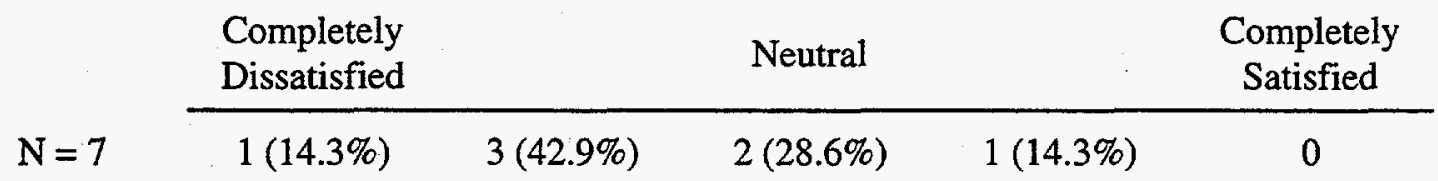

8. How much consideration was given to ES\&H issues during the design phase to manage the ES\&H risk associated with the project?

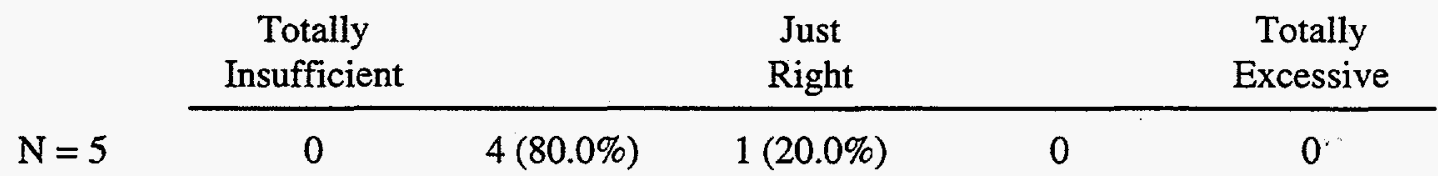

9. How satisfied were you with the amount of consideration given to ES\&H issues by the design group?

\begin{tabular}{cccccc} 
& $\begin{array}{l}\text { Completely } \\
\text { Dissatisfied }\end{array}$ & & Neutral & & $\begin{array}{c}\text { Completely } \\
\text { Satisfied }\end{array}$ \\
\cline { 2 - 6 } & 0 & $4(66.7 \%)$ & $2(33.3 \%)$ & 0 & 0
\end{tabular}

10. During the design phase, how involved was the future operating staff in reviewing the risk associated with operating the facility, equipment, or process following construction?

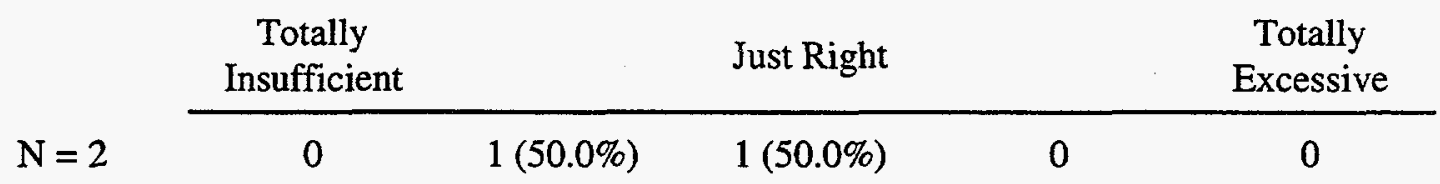

\section{ES\&H Issues}

11. To what extent were the construction plans evaluated for compliance with OSHA standards?

\begin{tabular}{|c|c|c|c|c|c|}
\hline & $\begin{array}{c}\text { Not Evaluated } \\
\text { At All }\end{array}$ & & $\begin{array}{l}\text { Adequately } \\
\text { Evaluated }\end{array}$ & & $\begin{array}{c}\text { Excessively } \\
\text { Evaluated }\end{array}$ \\
\hline$N=5$ & 0 & $2(40.0 \%)$ & $2(40.0 \%)$ & $1(20.0 \%)$ & 0 \\
\hline
\end{tabular}

12. During construction activities, did you notice representatives from any of the following groups also performing ES\&H oversight? Mark all that apply.

3 Construction Contractor's Safety Officer

1 ATLC (Union) Safety Representative

4 MK-Ferguson's ES\&H Representative

5 ORNL Safety and Health Evaluation and Support Team 
3 ORNL Division for whom work was being performed

2 ORNL Safety Department

4 ORNL Radiological Protection

0 ORNL Environmental Compliance and Documentation

0 ORNL Engineering's Electrical Safety Engineering Group

3 ORNL Fire Protection Engineering

0 Office of Operational Readiness and Facility Safety

0 LMES Safety and Health Representative

1 DOE-ORNL Site Office Facility

0 DOE-ORO ES\&H Representative

0 DOE-HQ Safety Representative

0 State of Tennessee ES\&H Representative

13. How much ES\&H oversight was given to the project to manage the level of hazard on the project?

\begin{tabular}{cccccc} 
& \multicolumn{1}{c}{$\begin{array}{c}\text { Totally } \\
\text { Insufficient }\end{array}$} & Just Right & \multicolumn{1}{c}{$\begin{array}{c}\text { Totally } \\
\text { Excessive }\end{array}$} \\
\cline { 2 - 6 } $\mathrm{N}=7$ & 0 & $5(71.4 \%)$ & $1(14.3 \%)$ & $1(14.3 \%)$ & 0
\end{tabular}

14. To what extent did ES\&H oversight add value to the project?

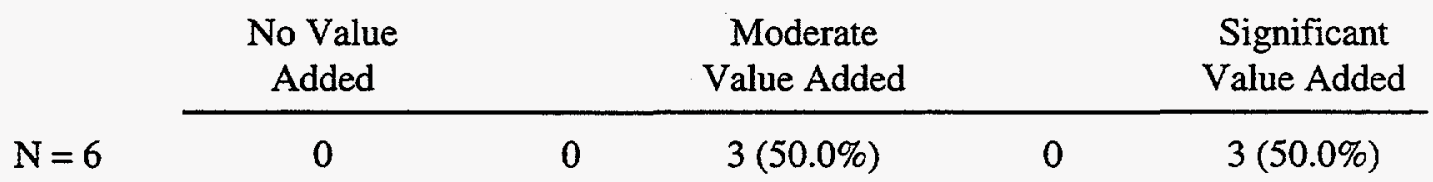

15. a) Were safety and health problems identified by ES\&H oversight?

\begin{tabular}{ccccc}
$N=6$ & $\begin{array}{c}\text { No } \\
\text { Findings }\end{array}$ & $\begin{array}{c}\text { Minor } \\
\text { Findings }\end{array}$ & $\begin{array}{c}\text { Moderate } \\
\text { Findings }\end{array}$ & $\begin{array}{c}\text { Serious } \\
\text { Findings }\end{array}$ \\
\cline { 2 - 5 } & 0 & $1(16.7 \%)$ & $3(50.0 \%)$ & $-2(33.3 \%)$
\end{tabular}

b) If problems were identified, were they corrected?

$$
\begin{array}{lll}
N=6 & 6(100 \%) \text { Yes } & 0 \text { No }
\end{array}
$$

16. To what extent was the schedule impacted by ES\&H oversight?

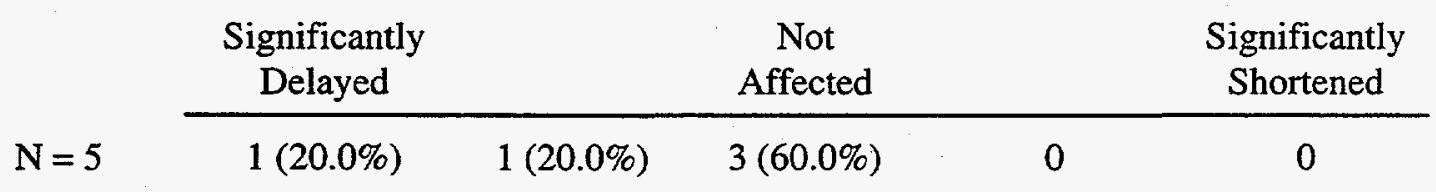


17. To what extent was the project cost impacted by ES\&H oversight?

$\mathrm{N}=4 \quad \frac{\begin{array}{c}\text { Significantly } \\ \text { Increased }\end{array}}{0} 2_{2(50.0 \%)} \frac{\begin{array}{c}\text { Not } \\ \text { Affected }\end{array}}{2(50.0 \%)} \quad 00 \frac{\begin{array}{c}\text { Significantly } \\ \text { Decreased }\end{array}}{0}$

Note: For "mark-all- that-apply" questions, the number of times a choice was marked is shown in the "Yes \#" column. No percentages are shown for these questions.

\begin{tabular}{|c|c|c|c|c|c|}
\hline \multicolumn{6}{|l|}{ Engineering Design and Construction Process Survey } \\
\hline \multicolumn{6}{|l|}{ Summary of Yes/No Responses from ES\&H Personnel } \\
\hline & & \multicolumn{2}{|c|}{ Yes } & \multicolumn{2}{|c|}{ No } \\
\hline Question & $\mathrm{N}$ & \# & $\%$ & $\#$ & $\%$ \\
\hline \multicolumn{6}{|l|}{ Systems Requirements Document } \\
\hline $\begin{array}{l}\text { 1a. Did any ES\&H personnel participate in the development of a Systems } \\
\text { Requirements Document for this project? }\end{array}$ & 5 & 3 & 60.0 & 2 & 40.0 \\
\hline \multicolumn{6}{|l|}{$\begin{array}{l}\text { 1b. If someone did participate, at what level did this participation occur? Mark } \\
\text { all that apply. }\end{array}$} \\
\hline Division Director & & 0 & & & \\
\hline Section Head & & 0 & & & \\
\hline Group Leader & & 2 & & & \\
\hline Other & & 2 & & & \\
\hline \multicolumn{6}{|l|}{$\begin{array}{l}\text { 3a. Who in your organization reviewed the Systems Requirements Document? } \\
\text { Mark all that apply. }\end{array}$} \\
\hline Division Director & & 0 & & & \\
\hline Section Head & & 0 & & & \\
\hline Group Leader & & 2 & & & \\
\hline ES\&H person assigned to the project & & 3 & & & \\
\hline Other & & 0 & & & \\
\hline \multicolumn{6}{|l|}{$\begin{array}{l}\text { 3b. Who in your organization approved the Systems Requirements Document? } \\
\text { Mark all that apply. }\end{array}$} \\
\hline Division Director & & 0 & & & \\
\hline Section Head & & 0 & & & \\
\hline Group Leader & & 0 & & & \\
\hline ES\&H person assigned to the project & & 0 & & & \\
\hline Other & & 0 & & & \\
\hline \multicolumn{6}{|l|}{ ES\&H Issues } \\
\hline \multicolumn{6}{|l|}{$\begin{array}{l}\text { 12. During construction activities, did you notice representatives from any of } \\
\text { the following groups performing ES\&H oversight? Mark all that apply. }\end{array}$} \\
\hline Construction Contractor's Safety Officer & & 3 & & & \\
\hline ATLC (Union) Safety Representative & & 1 & & & \\
\hline
\end{tabular}




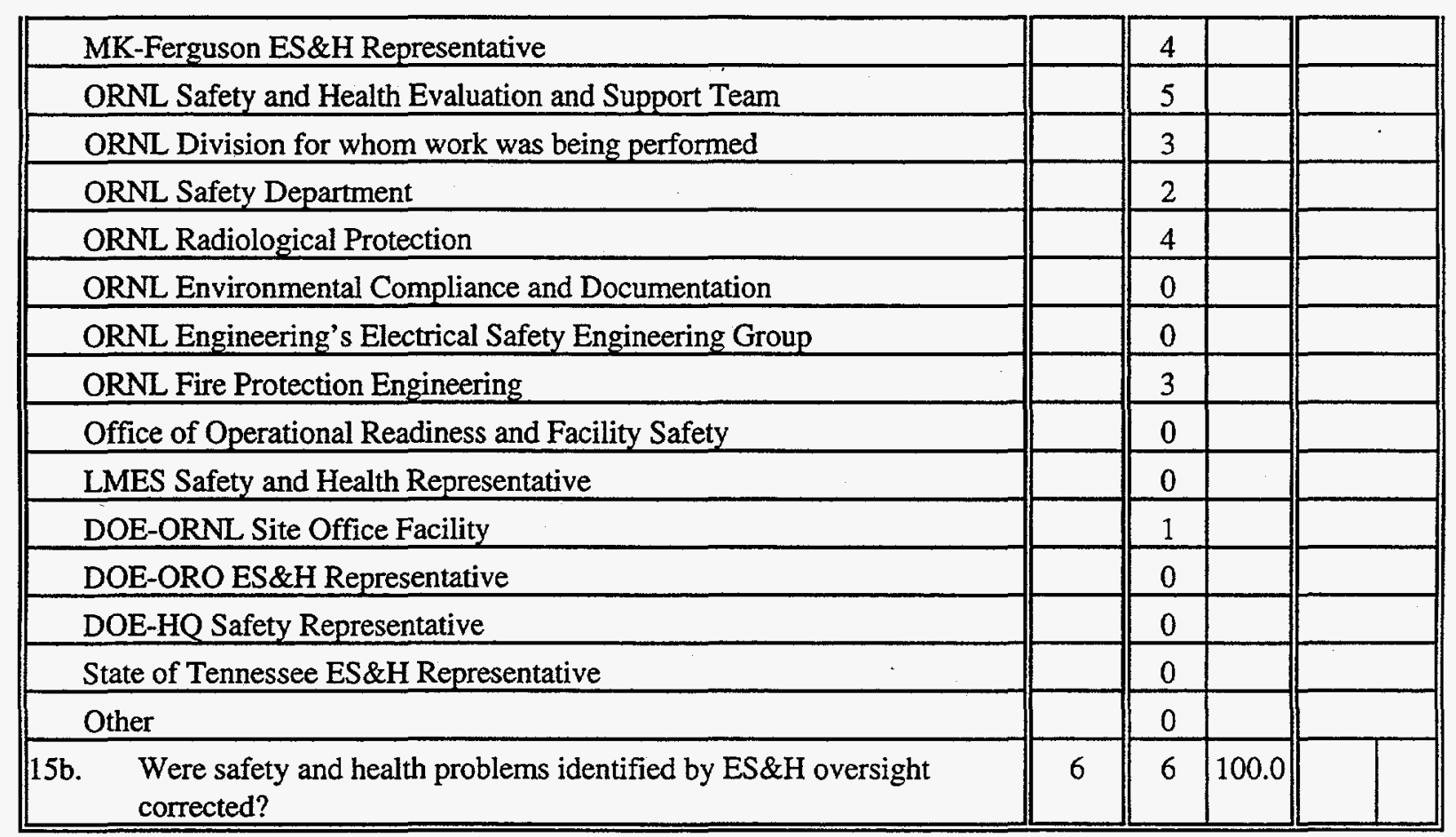

\section{C.1.2.6 Written Comments by Environmental, Safety, and Health Personnel}

Refer to the identification numbers at the end of the section to determine which groups the numbers on the left designate.

1b) "Other" ES\&H personnel who participated in the development of a Systems Requirements Document.

2 Staff

7 ES\&H person assigned to project

18. What are the barriers to accepting appropriate levels of project risk?

1 Having knowledgeable workers and planners.

2 The barriers are simply what level of risk the $M \& O$ contractor is willing to accept as opposed to what DOE is willing to permit.

4 Decisions are being made by individuals who seem ignorant of the risk issues.

7 DOE, lack of understanding of scope of work and any changes/deviations from original scope.

19. In what areas does ORNL do very well at accepting appropriate levels of project risk?

1 When pre-planning is done which involves ES\&H staff and oversight is strong.

2 Service subcontract jobs. Anything that involves DOE prime contractors ties our hands with unrealistic, problematic, and wasteful "drivers." 
20. If you could start with a "clean sheet," what would you like to have as ORNL's new Engineering Design and Construction Process?

1 SHEST Team does a good job but is limited in scope and personnel. It would help to cycle ORNL engineers through SHEST Team duties.

2 Until you resolve (if anyone can) the need for independence from DOE's requirements on contractor selection, oversight, and some design phase issues, it is moot to speculate on a new process.

4 Simplify, simplify, simplify!!!

6 Engineering needs to coordinate with more of the folks involved/affected by construction projects (i.e., facility managers, lessons learned, plant operations personnel) during planning phase of project. Involve $P \& E$ to perform some of the work if cost-effective. Coordinate with ES\&H to avoid built-in hazards, unnecessary risk to contractor personnel.

7 I would like to see ORNL's Engineering Design and Construction Process move this function to outside Design/Build Contractors. I would like Engineering to serve as liaison between the customer and ES\&H and design/build company to ensure customer needs are met.

21. What advice would you give to the Engineering Design and Construction Reengineering Team?

1 Look at how project affects the rest of the Lab.

2 Seek independence. Tolerate interdependence in the system. Strive for greater cost-efficient management and oversight protocol.

3 Not to look at ES\&H as the enemy.

4 Lower your cost!!

6 Get rid of Davis-Bacon. Fix firm end date for project completion and close project ESO number. Decrease cost overrun. Criteria for CID's-lots of times, it is an interpretation by contractor.

22. Please write in any other comments you have about your experience with this "typical" project or any other projects.

1 Most Lab-managed projects have been fine. ER projects cause the most problems-forced to subcontract and subcontractors don't know the "big" picture. Cost is king, but projects often end up costing more.

4 Once a certain level of radiation protection support is agreed to at the beginning of a project, have the construction engineers look for some other way to cut costs than by attempting to cut radiation protection support.

6 Use fixed price-too many CID's granted to contractors. ES\&H needs to be involved in design process, especially in early stages. Engineering does not notify the affected persons of changes in scope of work. Added work sometimes adds hazards (unaccounted for). 


\section{Identification}

\begin{tabular}{cll} 
ID & Organization & \multicolumn{1}{c}{ Project size } \\
\hline 1 & $\$ 350 \mathrm{~K}$ to $<\$ 2 \mathrm{M}$ \\
2 & Radiation Protection & $\$ 350 \mathrm{~K}$ to $<\$ 2 \mathrm{M}$ \\
3 & & $\$ 350 \mathrm{~K}$ to $<\$ 2 \mathrm{M}$ \\
4 & & Unspecified \\
5 & & $\$ 350 \mathrm{~K}$ to $<\$ 2 \mathrm{M}$ \\
6 & & $\$ 350 \mathrm{~K}$ to $<\$ 2 \mathrm{M}$ \\
\hline
\end{tabular}

\section{C.1.2.7 Summary of Responses from Contractors}

For each question, the number and percentage of respondents who selected a particular answer are shown in front of or below that answer, depending on the format of the question. Note that the percentage is calculated from the total number of respondents who answered the question after the "Don't Know/Not Applicable/No Opinion" responses were excluded. The total number of respondents is shown at the left margin. No percentages are shown for the "mark-all-that-apply" questions. There were 13 respondents to this survey.

\section{Design and Construction Risk}

Size of the project referred to:

1 Less than $\$ 100 \mathrm{~K}$

2 Greater than or equal to $\$ 100 \mathrm{~K}$ but less than $\$ 350 \mathrm{~K}$

6 Greater than or equal to $\$ 350 \mathrm{~K}$ but less than $\$ 2 \mathrm{M}$

2 Greater than or equal to $\$ 2 \mathrm{M}$

2 Haven't done work recently

\section{Design Requirements}

1. To what extent were the design requirements changed after the construction began?

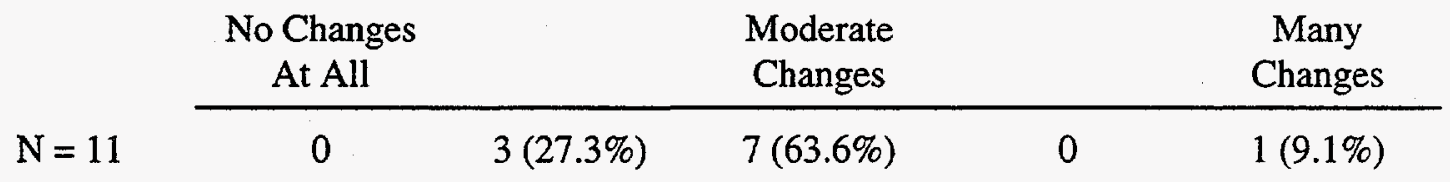


2. To what extent was the construction cost impacted by the changes in design requirements?

\begin{tabular}{|c|c|c|c|c|}
\hline & $\begin{array}{c}\text { Significantly } \\
\text { Increased }\end{array}$ & $\begin{array}{c}\text { Not } \\
\text { Affected }\end{array}$ & & $\begin{array}{c}\text { Significantly } \\
\text { Decreased }\end{array}$ \\
\hline$N=10$ & $3(30.0 \%)$ & $6(60.0 \%)$ & $1(10.0 \%)$ & 0 \\
\hline
\end{tabular}

\section{ES\&H Issues}

3. To what extent were construction ES\&H issues addressed in the design phase?

\begin{tabular}{|c|c|c|c|c|}
\hline & $\begin{array}{c}\text { Not Addressed } \\
\text { At All }\end{array}$ & & $\begin{array}{l}\text { Adequately } \\
\text { Addressed }\end{array}$ & $\begin{array}{c}\text { Excessively } \\
\text { Addressed }\end{array}$ \\
\hline$N=10$ & 0 & $2(20.0 \%)$ & $8(80.0 \%)$ & 0 \\
\hline
\end{tabular}

4. To what extent were the construction plans evaluated for compliance with OSHA standards?

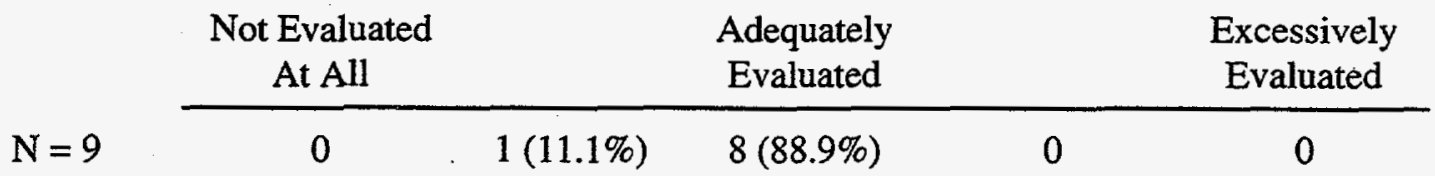

5. How much ES\&H oversight was given to the project to manage the level of hazard on the project?

\begin{tabular}{cccccc} 
& $\begin{array}{c}\text { Totally } \\
\text { Insufficient }\end{array}$ & Just & \multicolumn{1}{c}{$\begin{array}{c}\text { Totally } \\
\text { Excessive }\end{array}$} \\
\cline { 2 - 6 } $\mathrm{N}=11$ & 0 & 0 & 0 & $7(63.6 \%)$ & $4(36.4 \%)$
\end{tabular}

6. To what extent did ES\&H oversight add value to the project?

\begin{tabular}{|c|c|c|c|}
\hline & $\begin{array}{l}\text { No Value } \\
\text { Added }\end{array}$ & $\begin{array}{c}\text { Moderate } \\
\text { Value Added }\end{array}$ & $\begin{array}{l}\text { Significant } \\
\text { Value Added }\end{array}$ \\
\hline$N=11$ & $3(27.3 \%)$ & $4(36.4 \%)$ & $2(18.2 \%)$ \\
\hline
\end{tabular}

7. During construction activities, did you notice representatives from any of the following groups performing ES\&H oversight? Mark all that apply.

2 Another Construction Contractor's Safety Officer

0 ATLC (Union) Safety Representative

10. MK-Ferguson's ES\&H Representative

8 ORNL Safety and Health Evaluation and Support Team

4 ORNL Division for whom work was being performed

7 ORNL Safety Department

5 ORNL Radiological Protection 
6 ORNL Environmental Compliance and Documentation

3 ORNL Engineering's Electrical Safety Engineering Group

7 ORNL Fire Protection Engineering

0 Office of Operational Readiness and Facility Safety

8 LMES Safety and Health Representative

2 DOE-ORNL Site Office Facility Representative

3 DOE-ORO ES\&H Representative

1 DOE-HQ Safety Representative

0 State of Tennessee ES\&H Representative

8. a) Were safety and health problems identified by ES\&H oversight?

\begin{tabular}{ccccc}
$\mathrm{N}=9$ & $\begin{array}{c}\text { No } \\
\text { Findings }\end{array}$ & $\begin{array}{c}\text { Minor } \\
\text { Findings }\end{array}$ & $\begin{array}{c}\text { Moderate } \\
\text { Findings }\end{array}$ & $\begin{array}{c}\text { Serious } \\
\text { Findings }\end{array}$ \\
\cline { 2 - 5 } & 0 & $8(88.9 \%)$ & $1(11.1 \%)$ & 0
\end{tabular}

b) If problems were identified, were they corrected?

$$
\mathrm{N}=9 \quad .9(100 \%) \text { Yes } \quad 0 \text { No }
$$

9. To what extent was the schedule impacted by ES\&H oversight?

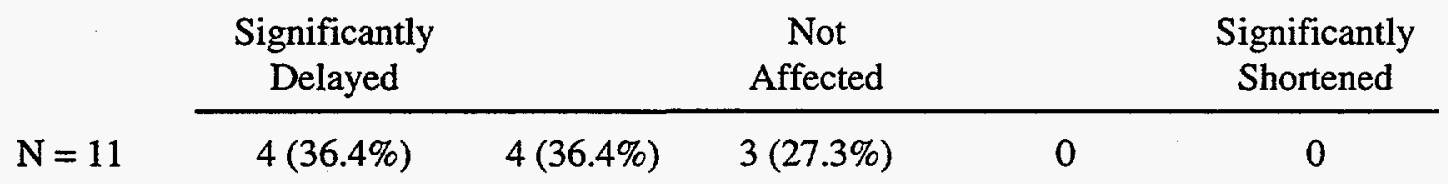

10. To what extent was the project cost impacted by ES\&H oversight?

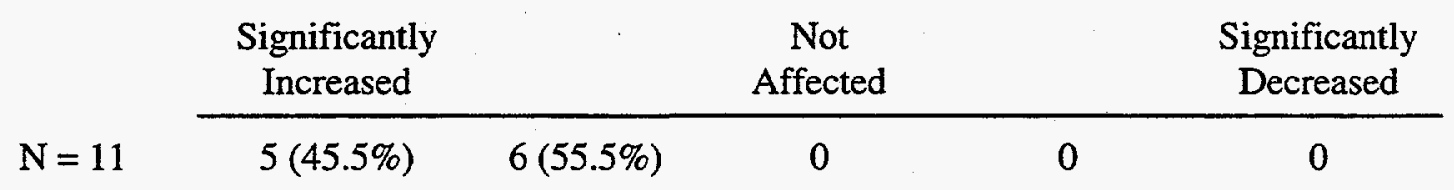

\section{General}

11. Who was your principal contact when working on the project at ORNL?

8 The Construction Manager (MK-Ferguson)

1 ORNL Engineering

0 The end user of what you were constructing

0 The DOE site representative

2 Other (see Comments for description) 
12. For the potential problems listed below, please indicate the degree to which they were a problem on the project.

\begin{tabular}{|c|c|c|c|c|c|c|}
\hline & & $\begin{array}{l}\text { Not a } \\
\text { Problem }\end{array}$ & & $\begin{array}{l}\text { Moderate } \\
\text { Problem }\end{array}$ & & $\begin{array}{l}\text { Critical } \\
\text { Problem }\end{array}$ \\
\hline a) & $\begin{array}{l}\text { Safety of the work crew } \\
(N=10)\end{array}$ & $10(100 \%)$ & 0 & 0 & 0 & 0 \\
\hline b) & $\begin{array}{l}\text { Unique hazards } \\
\text { (chemical, radioactive } \\
\text { materials, lasers, etc.) } \\
(N=10)\end{array}$ & $4(40.0 \%)$ & $4(40.0 \%)$ & $2(20.0 \%)$ & 0 & 0 \\
\hline c) & $\begin{array}{l}\text { Concerns by your work } \\
\text { crew regarding the } \\
\text { unique hazards }(N=10)\end{array}$ & $7(70.0 \%)$ & $2(20.0 \%)$ & $1(10.0 \%)$ & 0 & 0 \\
\hline d) & $\begin{array}{l}\text { The use of protective } \\
\text { equipment }(\mathrm{N}=10)\end{array}$ & $4(40.0 \%)$ & $3(30.0 \%)$ & $3(30.0 \%)$ & 0 & 0 \\
\hline e) & $\begin{array}{l}\text { Unrealistic expectations } \\
\text { of } M K-F, D O E, O R N L \text {, } \\
\text { etc. }(N=10)\end{array}$ & $2(20.0 \%)$ & $3(30.0 \%)$ & $3(30.0 \%)$ & $2(20.0 \%)$ & 0 \\
\hline f) & $\begin{array}{l}\text { Timely payment of your } \\
\text { expenses }(N=10)\end{array}$ & $5(50.0 \%)$ & $2(20.0 \%)$ & 0 & 0 & $3(30.0 \%)$ \\
\hline g) & $\begin{array}{l}\text { Changes in design during } \\
\text { construction }(\mathrm{N}=9)\end{array}$ & $3(33.3 \%)$ & $2(22.2 \%)$ & 0 & 0 & 0 \\
\hline h) & $\begin{array}{l}\text { Training requirements } \\
\text { for your work crew } \\
(\mathrm{N}=10)\end{array}$ & $1(10.0 \%)$ & $2(20.0 \%)$ & $5(50.0 \%)$ & $1(10.0 \%)$ & $1(10.0 \%)$ \\
\hline i) & $\begin{array}{l}\text { The Project Labor } \\
\text { Agreement }(N=10)\end{array}$ & $6(60.0 \%)$ & 0 & $1(10.0 \%)$ & $2(20.0 \%)$ & $1(10.0 \%)$ \\
\hline j) & $\begin{array}{l}\text { The use of a } \\
\text { Construction Manager } \\
\text { different from ORNL } \\
\text { management }(N=10)\end{array}$ & $3(30.0 \%)$ & $2(20.0 \%)$ & $3(30.0 \%)$ & 0 & $2(20.0 \%)$ \\
\hline k) & $\begin{array}{l}\text { Interfacing with the final } \\
\text { user/customer }(N=10)\end{array}$ & $8(80.0 \%)$ & 0 & 0 & $2(20.0 \%)$ & 0 \\
\hline
\end{tabular}


14. a) Based on your experiences at ORNL, would your company be interested in obtaining future contracts at this site?

\begin{tabular}{|c|c|c|c|c|}
\hline & $\begin{array}{c}\text { Definitely } \\
\text { Not }\end{array}$ & Maybe & & $\begin{array}{c}\text { Definitely } \\
\text { Yes }\end{array}$ \\
\hline$N=11$ & 0 & $1(9.1 \%)$ & $1(9.1 \%)$ & $9(81.8 \%)$ \\
\hline
\end{tabular}

b) If not, what are the primary reasons for not wanting to pursue further contracts? Mark all that apply.

1 Too much involvement by people not working on the project

1 The Project Labor Agreement

0 The hazards involved

0 Lack of timely payment by DOE/LMES/LMER

0 Training requirements

1 Unrealistic expectations by the customer

\section{Project Labor Agreement (PLA)}

Type of organization affiliated with:

5 Construction Contractor, general (union)

1 Construction Contractor, general (non-union)

4 Construction Contractor, specialty (union)

1 Construction Contractor, specialty (non-union)

0 Construction Manager

15. Please indicate your level of agreement with the statements below.

\begin{tabular}{|c|c|c|c|c|c|}
\hline & $\begin{array}{l}\text { Strongly } \\
\text { Disagree }\end{array}$ & Disagree & $\begin{array}{l}\text { Neither } \\
\text { Agree or } \\
\text { Disagree }\end{array}$ & Agree & $\begin{array}{c}\text { Strongly } \\
\text { Agree }\end{array}$ \\
\hline $\begin{array}{l}\text { The PLA is essential for } \\
\text { labor peace. }(N=10)\end{array}$ & $6(54.5 \%)$ & $1(9.1 \%)$ & 0 & $2(18.2 \%)$ & $2(18.2 \%)$ \\
\hline $\begin{array}{l}\text { The PLA increases } \\
\text { construction contractor } \\
\text { administrative costs. } \\
(\mathrm{N}=11)\end{array}$ & 0 & $3(27.3 \%)$ & $2(18.2 \%)$ & 0 & $6(54.5 \%)$ \\
\hline $\begin{array}{l}\text { The PLA contributes to } \\
\text { improved work quality. } \\
(\mathrm{N}=11)\end{array}$ & $2(18.2 \%)$ & $2(18.2 \%)$ & $2(18.2 \%)$ & $2(18.2 \%)$ & $3(27.3 \%)$ \\
\hline $\begin{array}{l}\text { The PLA provides } \\
\text { efficiency of construction } \\
\text { operations. }(N=10)\end{array}$ & $2(18.2 \%)$ & $3(27.3 \%)$ & $2(18.2 \%)$ & $2(18.2 \%)$ & $2(18.2 \%)$ \\
\hline
\end{tabular}


e) The PLA provides for peaceful settlement of

\begin{tabular}{ccccc}
$\begin{array}{c}\text { Strongly } \\
\text { Disagree }\end{array}$ & Disagree & $\begin{array}{c}\text { Neither } \\
\text { Agree or } \\
\text { Disagree }\end{array}$ & Agree & $\begin{array}{c}\text { Strongly } \\
\text { Agree }\end{array}$ \\
\hline $1(9.1 \%)$ & 0 & $1(9.1 \%)$ & $7(63.6 \%)$ & $2(18.2 \%)$
\end{tabular}
labor disputes. $(\mathrm{N}=11)$

f) The PLA assures competency of referred workers. $(N=11)$

g) The PLA contributes to $2(18.2 \%)$

$3(27.3 \%)$

$1(9.1 \%)$

$3(27.3 \%)$ improved worker attitudes. $(\mathrm{N}=11)$

h) The construction contractor can easily reject any referred applicant. $(\mathrm{N}=11)$

i) Work rules provisions of the PLA result in inefficiencies. $(\mathrm{N}=10)$

j) Smaller numbers of contractors are willing to $1(9.1 \%)$ $3(27.3 \%)$ $1(9.1 \%)$ $4(36.4 \%)$ bid on work at ORNL because of the PLA. $(\mathrm{N}=10)$

k) Bid prices for work at ORNL are increased by the PLA. $(\mathrm{N}=11)$

1) Working under the PLA $1(9.1 \%)$ $4(36.4 \%)$ $2(18.2 \%)$ $3(27.3 \%)$ $1(9.1 \%)$ makes contractors less competitive for local commercial work. $(\mathrm{N}=11)$

m) Unknown attitude of $1(9.1 \%)$ $3(27.3 \%)$ $2(18.2 \%)$ $1(9.1 \%)$ PLA-referred workers leads to increased bid prices. $(\mathrm{N}=11)$

n) Unknown productivity of PLA-referred workers leads to increased bid prices. $(\mathrm{N}=11)$ 


\begin{tabular}{|c|c|c|c|c|c|c|}
\hline & & $\begin{array}{l}\text { Strongly } \\
\text { Disagree }\end{array}$ & Disagree & $\begin{array}{l}\text { Neither } \\
\text { Agree or } \\
\text { Disagree }\end{array}$ & Agree & $\begin{array}{c}\text { Strongly } \\
\text { Agree }\end{array}$ \\
\hline o) & $\begin{array}{l}\text { Administrative burden } \\
\text { related to the PLA favors } \\
\text { larger contractors. } \\
(\mathrm{N}=11)\end{array}$ & $2(18.2 \%)$ & $4(36.4 \%)$ & $1(9.1 \%)$ & $1(9.1 \%)$ & $3(27.3 \%)$ \\
\hline p) & $\begin{array}{l}\text { The PLA adds to overall } \\
\text { construction costs. } \\
(\mathrm{N}=11)\end{array}$ & 0 & $4(36.4 \%)$ & $1(9.1 \%)$ & 0 & $6(54.5 \%)$ \\
\hline q) & $\begin{array}{l}\text { Eliminating the threat of } \\
\text { strikes and lockouts is } \\
\text { worth any extra cost of } \\
\text { the PLA. }(N=11)\end{array}$ & $3(27.3 \%)$ & $3(27.3 \%)$ & 0 & $5(45.5 \%)$ & 0 \\
\hline r) & $\begin{array}{l}\text { After the present PLA } \\
\text { expires, a new PLA } \\
\text { should be developed. } \\
(N=11)\end{array}$ & $4(36.4 \%)$ & $2(18.2 \%)$ & $1(9.1 \%)$ & 0 & $4(36.4 \%)$ \\
\hline s) & $\begin{array}{l}\text { The PLA essentially } \\
\text { excludes non-union } \\
\text { workers. }(\mathrm{N}=10)\end{array}$ & $1(10.0 \%)$ & $2(20.0 \%)$ & $2(20.0 \%)$ & $4(40.0 \%)$ & $1(10.0 \%)$ \\
\hline t) & $\begin{array}{l}\text { Union contractors } \\
\text { receive favoritism from } \\
\text { the } \mathrm{KBCTC} .(\mathrm{N}=11)\end{array}$ & $1(9.1 \%)$ & $4(36.4 \%)$ & $2(18.2 \%)$ & $4(36.4 \%)$ & 0 \\
\hline u) & $\begin{array}{l}\text { The referral process is } \\
\text { always objective (strictly } \\
\text { "by the list"). (N=11) }\end{array}$ & $1(9.1 \%)$ & $3(27.3 \%)$ & $4(36.4 \%)$ & $3(27.3 \%)$ & 0 \\
\hline v) & $\begin{array}{l}\text { I have spent less time } \\
\text { dealing with labor } \\
\text { jurisdictional issues since } \\
\text { the PLA took effect. } \\
(\mathrm{N}=11)\end{array}$ & 0 & $2(18.2 \%)$ & $4(36.4 \%)$ & $3(27.3 \%)$ & $2(18.2 \%)$ \\
\hline w) & $\begin{array}{l}\text { My responses to items } \\
\text { a-v are based on direct, } \\
\text { personal experience. } \\
(\mathrm{N}=11)\end{array}$ & 0 & 0 & 0 & $3(27.3 \%)$ & $8(72.7 \%)$ \\
\hline
\end{tabular}


Note: For "mark-all-that-apply" questions, the number of times a choice was marked is shown in the "Yes \#" column. No percentages are shown for these questions.

\begin{tabular}{|c|c|c|c|c|c|}
\hline \multicolumn{6}{|c|}{ Engineering Design and Construction Process Survey } \\
\hline \multicolumn{6}{|l|}{ Summary of Yes/No Responses from Contractors } \\
\hline & & \multicolumn{2}{|c|}{ Yes } & \multicolumn{2}{|c|}{ No } \\
\hline Question & $\mathrm{N}$ & $\#$ & $\%$ & $\#$ & $\%$ \\
\hline \multicolumn{6}{|l|}{ ES\&H Issues } \\
\hline $\begin{array}{l}\text { 7. During construction activities, did you notice representatives from any } \\
\text { of the following groups performing ES\&H oversight? Mark all that } \\
\text { apply. }\end{array}$ & & & & & \\
\hline Another Construction Contractor's Safety Officer & & 2 & & & \\
\hline ATLC (Union) Safety Representative & & 0 & & & \\
\hline MK-Ferguson ES\&H Representative & & 10 & & & \\
\hline ORNL Safety and Health Evaluation and Support Team & & 8 & & & \\
\hline ORNL Division for whom work was being performed & & 4 & & & \\
\hline ORNL Safety Department & & 7 & & & \\
\hline ORNL Radiological Protection & & 5 & & & \\
\hline ORNL Environmental Compliance and Documentation & & 6 & & & \\
\hline ORNL Engineering's Electrical Safety Engineering Group & & 3 & & & \\
\hline ORNL Fire Protection Engineering & & 7 & & & \\
\hline Office of Operational Readiness and Facility Safety & & 0 & & & \\
\hline LMES Safety and Health Representative & & 8 & & & \\
\hline DOE-ORNL Site Office Facility & & 2 & & & \\
\hline DOE-ORO ES\&H Representative & & 3 & & & \\
\hline DOE-HQ Safety Representative & & 1 & & & \\
\hline State of Tennessee ES\&H Representative & & 0 & & & \\
\hline $\begin{array}{l}\text { 8b. Were safety and health problems identified by ES\&H oversight } \\
\text { corrected? }\end{array}$ & 9 & 9 & 100.0 & 0 & 0.0 \\
\hline \multicolumn{6}{|l|}{ General } \\
\hline \multicolumn{6}{|l|}{$\begin{array}{l}\text { 14b. What are the primary reasons for not wanting to pursue future } \\
\text { contracts at ORNL? Mark all that apply. }\end{array}$} \\
\hline Too much involvement by people not working on the project & & 1 & & & \\
\hline The Project Labor Agreement & & 1 & & & \\
\hline The hazards involved & & 0 & & & \\
\hline Lack of timely payment by DOE/LMES/LMER & & 0 & & & \\
\hline Training requirements & & 0 & & & \\
\hline Unrealistic expectations by the customer & & 1 & & & \\
\hline
\end{tabular}




\section{C.1.2.8 Written Comments by Contractors}

Refer to the identification numbers at the end of the section to determine which groups the numbers on the left designate.

7. During construction activities, did you notice representatives from any of the following groups performing ES\&H oversight?

13 I was on the job site only two times.

11. "Other" principal contact when working on the project at ORNL.

9 Foley Company

13 Job superintendent

13. How many construction projects have you been involved in at ORNL?

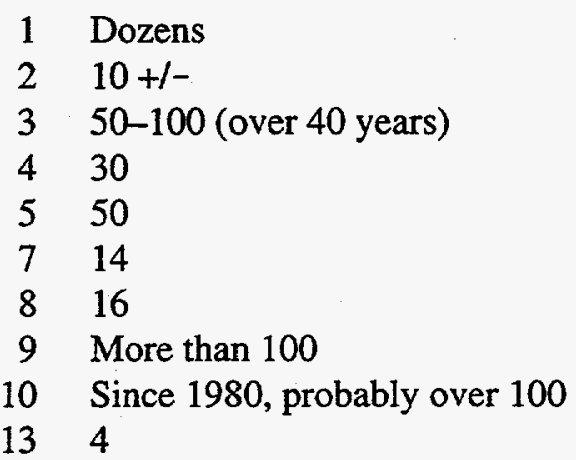

16. How has the PLA affected your labor productivity?

1 Labor productivity has decreased.

2 Refusal of trades to "cross-trade" when required on small tasks. (Carpenter won't help iron worker if needed, for example). Work rules are nonproductive.

4 We have been in the market for a long time ... know the workers and who is good. We try to build a team of good people. No different in any other sector of country-union or not-building a good team is knowing people prior to hiring or trial and error.

5 Labor productivity is now measurable, less risky, and, therefore, less costly.

6 None.

7 Increased costs by requiring extra people on a project. For example, only operating engineers are to operate forklifts.

8 Extremely cumbersome to obtain people on short notice. Core list is ridiculous.

9 None.

10 As a small contractor, we have five full-time craftsmen (carpenters, laborers, and operator). Productivity is normal with these men. My experience is that $25 \%$ of referred union workers' productivity is sufficient. 
17. How has the PLA affected the quality of work?

1 Believe it has had no effect one way or the other.

2 The agreement itself does not affect quality. The union training programs are good.

4 Generally of the best quality. Remember the layers of inspectors-MK-F/LMES or LMER/DOE, etc. This ensures quality also.

5 PLA has assured my company of a labor pool familiar with quality requirements that are unique to ORNL.

6 Improved.

7 Neither helped nor hurt.

8 Hard to get qualified people.

9 None.

10 The quality of our work in the end must meet specifications by contract; however, we have no guarantee from MK-F or the local unions that craftsmen will produce quality work. Many times workers have been released due to lack of quality after the expense of hire-in. The price of quality is more.

18. What changes would you suggest if a new PLA is developed for ORNL?

1 Delete 4 core employees and allow employees to cross trades; that is, laborer be allowed to install wire mesh or set reinforcing dowels, etc.

2 Require cross-trade work on jobs less than \$1-2 million as directed by contractor management. Composite crews can be led by journeyman of the trade performing the work being performed (i.e., if tying rebar, have one journeyman IW; the other trades on the crew can "help").

3 Eliminate the PLA and revert to basic Davis-Bacon requirements. If this is reinstituted, make a requirement that unions shall maintain a pool of qualified, specifically trained workers (i.e., craft, safety, etc.).

4 If it ain't broke, don't fix it!

5 None.

6 None.

7 Eliminate the Project Labor Agreement.

8 Eliminate it-a PLA is not necessary.

9 Change core employee designation to be more flexible.

10 There should be some recourse for recovering losses due to incompetent workers. I also think that the wage scale is too high. Compare it to TVA PLA and commercial scales in Knoxville.

19. What aspects of construction at ORNL do you like the least?

1 Amount of paperwork required for submittals.

2 Work being stopped for petty or minor reasons such as not having a written plan submitted for spill protection, erosion control, etc. Ridiculous interpretations of OSHA, environmental regulations, etc.

3 Delays and lack of timely decisions.

4 The lack of it! Very difficult to keep good crews together without steady supply of work!

6 ES\&H.

7 Project Labor Agreement.

8 Extreme ES\&H oversight. Dealing with the PLA. 
9 Multiple oversight of safety has been a problem in the past but not as bad for the last 8-12 months.

10 QA, safety, and training are areas that are costing more than necessary. My opinion is that at least small projects could be contracted directly with LMES.

20. What advice would you give to the Engineering Design and Construction Reengineering Team?

1 Start thinking along the lines of commercial-type construction.

2 . Eliminate duplication of construction engineering/construction management roles by having one central group responsible for construction-all of it. I do not believe having a construction management contractor adds any value at all. I believe it only adds tremendously to the cost.

3 Determine your purpose and pursue all phases to a finite conclusion (i.e., scope, permits, funding, approvals, compliance monitoring).

4 Task releases are good idea. Selects qualified contractors and keeps their people busy.

5 The establishment of a qualified contractor list based upon SIC or scope of work activities, thereby eliminating the risk of a contractor who has failed to perform to the CPM and quality expectations of LMER and ORNL in the past from "low balling" one project in order to gain access to the site and then commence claims for change orders and delays to make up their original shortfall.

6 Have ES\&H meet with specialty contractors prior to bid time to review parameters of accepted safety practices. Parameters which will remain constant throughout the work process.

7 Consider the cost of ES\&H/OSHA requirements associated with each project.

8 Make sure the plans and specifications are complete and complement each other. Take time to work out the details.

9 Allow the "owners" of the projects (maintenance, firemen, managers, etc.) to fully review plans and specs at $90 \%$. Most changes are due to the likes and dislikes of these people.

10 Compare costs of projects in 1997 with equal projects in 1992. Read B. L. Morgan's thesis dated $5 / 10 / 96$.

21. Please write in any other comments you have about your experience with construction projects at ORNL.

1 Overall experience has been good. Just seems there is an easier, more economical way of doing business that is being overlooked.

7 Responses in items 8, 9, and 10 are in regard to the "hoisting and rigging shutdown" ordered by the Manager, DOE Oak Ridge Operations, on November 5, 1994.

9 Work at ORNL has been a large part of our business over the last 50 years, and we hope it will be for the next 50 . We are flexible, and we want the opportunity to exceed your expectations by offering you quality electrical and communications installations.

10 Let LMES handle the design. 


\section{Identification}

\begin{tabular}{cll} 
ID & \multicolumn{1}{c}{ Project Size } & \multicolumn{1}{c}{ Organization Type } \\
\hline 1 & $\$ 350 \mathrm{~K}$ to $<\$ 2 \mathrm{M}$ & Union/General \\
2 & $\$ 350 \mathrm{~K}$ to $<\$ 2 \mathrm{M}$ & Union/General \\
3 & $\$ 350 \mathrm{~K}$ to $<\$ 2 \mathrm{M}$ & Union/Gen./Spec. \\
4 & $\$ 350 \mathrm{~K}$ to $<\$ 2 \mathrm{M}$ & Union/Speciality \\
5 & $\$ 100 \mathrm{~K}$ to $<\$ 350 \mathrm{~K}$ & Union/General \\
6 & $<\$ 100 \mathrm{~K}$ & Union/Speciality \\
7 & $\$ 350 \mathrm{~K}$ to $<\$ 2 \mathrm{M}$ & Non-union/Speciality \\
8 & $\$ 2 \mathrm{M}$ & Union/General \\
9 & $\$ 2 \mathrm{M}$ & Union/Speciality \\
10 & $\$ 350 \mathrm{~K}$ to $<\$ 2 \mathrm{M}$ & Non-union/General \\
11 & Hasn't done work at & \\
& ORNL recently & \\
12 & Hasn't done work at & \\
13 & ORNL recently & \\
\hline
\end{tabular}

\section{C.1.3 Conclusions}

Study of survey responses reveals several areas where there is significant dissatisfaction with the existing engineering design and construction processes. The most striking conclusions are summarized below.

\section{C.1.3.1 Customer Survey Major Conclusions}

ORNL independent ES\&H oversight is conducted by numerous organizations in an uncoordinated manner and adds substantially to project costs and negatively impacts the project schedule. The following were noted:

- numerous representatives from several organizations were observed performing ES\&H oversight during construction activities,

- $55 \%$ of customers thought that excessive ES\&H oversight was given to the project to manage the level of hazard on the project,

- $59 \%$ of customers thought that ES\&H oversight added no or little value to the project,

- $50 \%$ of customers experienced delays due to ES\&H oversight, and

- $70 \%$ of customers said that project cost was increased by ES\&H oversight. 
There is dissatisfaction by ORNL end users regarding timeliness and cost-effectiveness of work performed through the construction manager. Obtaining construction services through a third party is seen to be inefficient and costly:

- $62 \%$ of customers were generally dissatisfied with MK-Ferguson as the maintenance/construction provider,

- $81 \%$ were dissatisfied with the cost performance of MK-Ferguson,

- $81 \%$ were dissatisfied with the schedule performance of MK-Ferguson,

- $62 \%$ of customers were dissatisfied with MK-Ferguson's level of productivity,

- $57 \%$ of customers were dissatisfied with the amount of time spent initiating and following through on MK-Ferguson project(s),

- $84 \%$ of customers were dissatisfied with the amount of time it took to complete the whole maintenance/construction process when MK-Ferguson was involved,

- $0 \%$ of customers thought MK-F to be the best qualified to perform maintenance/construction activities for project size less than $\$ 350 \mathrm{~K}$, and

- $91 \%$ of customers rate the current process for obtaining construction services from MK-Ferguson as burdensome.

The Labor Standards (Davis-Bacon) review process is time-consuming possibly because poor timeliness and cost-effectiveness of work done through the third-party construction manager causes end users to desire a maintenance determination for small jobs. The following responses were noted:

- $50 \%$ of customers have to interact two times with Labor Standards to receive a ruling, and

- $57 \%$ of customers interact with Labor Standards because of disagreement about the ruling.

\section{C.1.3.2 Project Engineer and Manager Survey Conclusions}

Project engineers and managers roughly agree with customers about the extent of change in design requirements after the project was started, but project engineers and managers believe the cost impact of the design changes to be more significant.

Project engineers and managers indicate that ORNL independent ES\&H oversight is conducted by numerous organizations in an uncoordinated manner, adds substantially to project costs, and negatively impacts the project schedule. Survey responses include the following:

- numerous representatives from several organizations were observed performing ES\&H oversight during construction activities,

- $47 \%$ of project engineers and managers believe that excessive ES\&H oversight was given to manage the level of hazard on the project, 
- $72 \%$ of project engineers and managers believe that ES\&H oversight added little value to the project,

- $47 \%$ of project engineers and managers said that project schedule was impacted by ES\&H oversight, and

- $59 \%$ of project engineers and managers said that project cost was increased by ES\&H oversight.

There is dissatisfaction by project engineers and managers regarding timeliness and cost-effectiveness of work performed through the construction manager. Obtaining construction services through a third-party construction manager is seen to be inefficient and costly:

- $50 \%$ of project engineers and managers were generally dissatisfied with the maintenance/construction provider when the provider was MK-Ferguson;

- $83 \%$ of project engineers and managers were dissatisfied with the cost performance of the maintenance/construction provider when the provider was MK-Ferguson;

- $61 \%$ of project engineers and managers were dissatisfied with the schedule performance of the maintenance/construction provider when the provider was MK-Ferguson;

- $72 \%$ of project engineers and managers were dissatisfied with the time MK-Ferguson took to begin the maintenance/construction work;

- $67 \%$ of project engineers and managers were dissatisfied with the time it took MK-Ferguson to complete the whole maintenance/construction process; and

- $90 \%$ believe that $P \& E$ is best qualified to perform maintenance/construction activities on projects smaller than $\$ 100 \mathrm{~K}$, and only $22 \%$ believe that $\mathrm{MK}-\mathrm{F}$ is best qualified to perform maintenance/construction activities between $\$ 100 \mathrm{~K}$ and $\$ 350 \mathrm{~K}$.

Project engineers and managers experience with P\&E was somewhat worse than end-user experience:

- $57 \%$ experienced low productivity with P\&E,

- $63 \%$ were dissatisfied with the time it took P\&E to begin the maintenance/construction work, and

- $52 \%$ were dissatisfied with the time it took P\&E to complete the whole maintenance construction process.

Project engineers and managers overwhelmingly prefer (90\%) P\&E for maintenanceiconstruction activities under $\$ 100 \mathrm{~K}$.

The Labor Standards (Davis-Bacon) review process is time-consuming. Of project engineers and managers, $69 \%$ experienced schedule delays because of the time required for rulings. 


\section{C.1.3.3 ES\&H Personnel Survey Conclusions}

ES\&H personnel do not feel adequately involved in the design phase of projects:

- $57 \%$ said that the design organization did not consult with them during the design phase of the project;

- $57 \%$ were not satisfied with the extent to which they were involved in the design process;

- $80 \%$ felt that insufficient consideration was given to ES\&H issues during the design phase to manage the ES\&H risk associated with the project;

- $67 \%$ were dissatisfied with the amount of consideration given to ES\&H issues by the design group; and

- $70 \%$ said that, during the design phase, the future operating staff was insufficiently involved with reviewing the risk associated with operating the facility, equipment, or process following construction.

In contrast to end users, project engineers and managers, and contractors, ES\&H personnel felt that insufficient ES\&H oversight was given to the project to manage the level of hazard on the project and that ES\&H oversight added significant value to the project. ES\&H personnel agree with the other groups that ES\&H oversight increased project cost.

\section{C.1.3.4 Contractor Survey Conclusions}

Of the contractors surveyed, $90 \%$ felt that cost of construction was increased by changes in design requirements.

Contractors indicate that ORNL independent ES\&H oversight is conducted by numerous organizations in an uncoordinated manner and adds substantially to project costs and negatively impacts the project schedule. The following were noted:

- numerous representatives from several organizations were observed performing ES\&H oversight during construction activities,

- $100 \%$ believe that excessive ES\&H oversight was given to the project to manage the level of hazard on the project,

- $64 \%$ said that ES\&H oversight added little value to the project,

- $73 \%$ said that the project schedule was delayed by ES\&H oversight, and

- $100 \%$ said that project cost was increased by ES\&H oversight. 
Of the contractors surveyed, $50 \%$ indicated that the use of a construction manager different from ORNL management is a moderate-to-critical problem, and 50\% see unrealistic expectations of MK-Ferguson, DOE, ORNL, etc., as problematical.

Contractors were divided as to whether the PLA is a problem, but the majority don't see the PLA as essential for labor peace. They largely agree that the PLA provides for peaceful settlement of labor disputes but results in inefficiencies and higher bid prices. 


\section{C.2 BENCHMARKING (E. C. Fox)}

\section{C.2.1 Process}

A benchmarking subteam was established to determine how DOE laboratories, universities, and other similar institutions perform engineering design and construction with the goal of understanding the policies and practices that have worked well for them. We held discussions with eight institutions:

Argonne National Laboratory (ANL)-video conference

Lawrence Berkeley National Laboratory (LBNL) — video conference/site visit

Brookhaven National Laboratory (BNL) - video conference

Pacific Northwest National Laboratory (PNNL) - video conference

Lawrence Livermore National Laboratory (LLNL) - site visit to ORNL

University of Tennessee (UT) - site visit to UT

Arnold Engineering Development Center (AEDC)-telephone conference

National Renewable Energy Laboratory (NREL) - telephone conference

We chose to benchmark other national laboratories because they have a very similar work structure and operate in the same system. We talked to all of the Energy Research laboratories and added LLNL and NREL to gain additional perspective. We benchmarked UT and the AEDC because they are similar research and development institutions located in East Tennessee.

Most of the benchmarking was accomplished by using video conferences, which allowed the entire team to participate without the time and expense of travel. This was believed to be very effective. Lawrence Livermore chose to visit ORNL. We visited UT and had telephone discussions with NREL and AEDC.

\section{C.2.2 Results}

Information obtained from each of the eight institutions is summarized in the succeeding sections of this report.

\section{C.2.3 Conclusions}

- For the most part, the institutions we benchmarked seem very satisfied and, in fact, proud of the way they manage and conduct engineering design and construction activities.

- All of the DOE labs appear to implement the Davis-Bacon Act in the same manner. Each has an internal committee that recommends to DOE what category the work falls under, and the DOE operations office makes the official determination. There is almost no disagreement between the other Energy Research laboratories and DOE in regard to these determinations. All of the labs use the Davis-Bacon Act as the definition of construction. However, because all except one of the other labs do not use a construction manager and have flexibility in how they contract construction, implementation of the Davis-Bacon Act is not a significant issue. At ORNL the Davis-Bacon Act determination defines whether ORNL or MK-Ferguson manages the project. The other labs don't have this complication with its inefficiencies and added costs. In fact, the other labs view the DavisBacon review as a useful tool to minimize grievances filed by their captive crafts against construction-type work. 
- Only one DOE lab other than ORNL uses a general project labor agreement for their construction contracts. While the others have had strikes and threats of strikes, they see no advantage in constraining their construction contractors into a specific way of organizing and using their labor force. Since they are hiring construction contractors for their expertise, the best approach is to allow the contractor to conduct business as the constructor knows best and to not micromanage, least of all their labor force. At the government part of PNNL, there is an agreement similar to a PLA that is managed by the site contractor, Fluor Daniels. PNNL doesn't appear to have too much trouble working with the PLA, but they have a unique arrangement between the private and government parts of their operations. They have private facilities in which they conduct DOE research. The private side does not use a PLA for the construction activities; instead, a combination of in-house labor and subcontractors is used who can call upon any labor force they choose. The University of Tennessee, who has substantial construction projects in the Knoxville area, does not use a PLA; neither does the AEDC. They do not see any benefit to using a PLA. They stay completely out of the labor relations of their contractors.

- With the exception of the government part of PNNL, other Energy Research laboratories do not use a construction manager. They all manage their own construction projects with their in-house staff. They all feel very strongly that having control over the project is essential to containing costs and to ensuring quality. PNNL uses Fluor-Daniel to manage its construction projects on the Hanford site. This seems to be workable for them, but it is not the approach they would choose if given the option. The private side of PNNL manages their own construction projects.

- Most of the other Energy Research laboratories have minimal levels of ES\&H oversight. The other labs have essentially the same safety risks but probably do not have as much site contamination as ORNL. They empower their line management and hold them accountable for safety and health issues. They have minimal staff support that acts in advisory capacity. The University of Tennessee has no oversight and holds their contractors totally accountable. LLNL, a DOE-defense programs lab, also reports having multiple layers of oversight. They are very frustrated with this arrangement and strongly desire to fix it.

- Several of the labs identified innovative, cost-effective contracting approaches. These include the use of prequalified contractors under task order-type agreements who can respond quickly and effectively to short-turnaround projects. These projects would typically have a total cost of $\$ 300,000$ or less. They also have prequalified contractors bid on their larger fixed-price contracts. This ensures that they get the best quality at the lowest price. Another innovation is the use of labor-hour contracts to access building trades. These are contracts based on hourly rates for utilization of construction trades. The labor is supervised by lab staff for these construction projects. The labor rates still fall under the restrictions of the Davis-Bacon Act. All labs must meet DOE minority and small-business requirements, but none of the other energy research labs focus on construction to meet these goals. They use $8 \mathrm{~A}$ contractors when they have demonstrated competence.

- All of the other labs are allowed to manage the engineering design for construction projects. Where appropriate, they perform in-house design along with the use of subcontracted design assistance. They all felt that in many instances their in-house design team is much more cost-effective than subcontracted design because the in-house staff understand the site and the design requirements. In all cases, they manage the design process and the contracts.

- The labs use various performance measures that don't seem to be consistent; however, schedule and cost seem to be the most common and relevant. 


\section{C.2.4 Recommendations}

- ORNL should consider managing its own construction projects. No other Energy Research laboratory uses a construction manager (except the government part of PNNL) because they do not see any cost or management advantage.

- ORNL should carefully consider a broader range of options than the present PLA. Other Energy Research laboratories do not bind themselves to this type of agreement, in an effort to give their subcontractors the flexibility to select and manage their own staff.

- ORNL should consider prequalifying design and construction contractors. Many other labs use prequalified contractors and are very satisfied with this approach.

- ORNL should establish a streamlined ES\&H approach in which the project manager is given overall responsibility. The best practices seem to incorporate very simple lines of responsibility and only one level of independent oversight.

- ORNL should hold the construction contractors accountable for all of their activities. Other sites seem to have good success when they hire qualified contractors and hold them accountable for ES\&H and the execution of their contract.

- ORNL should institute a streamlined Labor Standard Review Process. Other labs have a simple process that is very efficient and meets the requirements of the Davis-Bacon Act.

\section{C.2.5 Argonne National Laboratory Video Conference}

On April 24,1997, we conducted a video conference with the Argonne National Laboratory (ANL). In attendance from ANL were Rudie Bouie, Director, Plant Facilities and Services Division (also known as Site Manager), and Rob Malhotra, Manager of Strategic Planning. In attendance from ORNL were Ted Fox, Tom Etheridge, Ray Juras, Jim Mathys, Joe Setaro, Larry Kelley, and B. L. (Dell) Morgan.

ANL has 130 buildings on 1500 acres. The buildings constitute 4.8 million sq. $\mathrm{ft}$. Their GPP budget is about $\$ 5$ million per year; GPE, $\$ 2$ million; and major line items, $\$ 8$ million. All GPE and GPP decisions are made by the Chief Operations Officer based on the recommendations of the Director of Plant Facilities and Services.

In Rudie Bouie's position as Site Manager, he is responsible for all activities that involve buildings and grounds. The research organizations pay rent, and he acts as the landlord. He provides all maintenance (excluding programmatic) and plans and manages all building-related construction activities. He is also the Laboratory's person responsible for Davis-Bacon review. All items that are not specifically spelled out as exempt from the Davis-Bacon Act are sent to him, and he makes a recommendation to DOE, who then makes the official determination.

DOE almost always follows his recommendation. ANL wants DOE to make the determination because it clarifies the legal situation and reduces union issues.

ANL has nine separate unions with whom they negotiate. The fact that DOE makes the Davis-Bacon determination curtails many of the potential union grievances. ANL has no general PLA with the local building trades. However, they did use a PLA for the Advanced Photon Source. There is quite a bit of in- 
fighting amongst the local unions, particularly between those in Cook and DuPage Counties (ANL is in DuPage Co.). There have been strikes, but they don't view them as a problem. ANL stays completely out of the contractor's labor problems.

ANL does not use a general construction manager. They manage all of their own construction projects. Their facility engineering staff is about 40 people, and they handle about $\$ 15$ million per year in construction projects. This team includes both project management and design. The facility staff do no research-related work. For the Advanced Photon Source, ANL had a project office that was separate from the lab operating organization but staffed with ANL employees; some were from Bouie's organization. They hired an A/E, Lester B. Knight, to do the design and they used Rust Engineering to coordinate construction.

They are not required to follow either the Federal Acquisition Regulations (FAR) or DOE Acquisition Regulations (DEAR); rather, DOE allows ANL via their contract to follow best commercial practices. ANL does their own Title I and II design with certain exceptions. They found this arrangement to be more efficient than and as cost-effective as using subcontractors. They competitively bid their construction projects on a fixed-price basis. They also have a labor-hour contract that provides electrical, mechanical, and general labor for construction-like activities (Davis-Bacon). ANL provides the supervision. They competitively bid the larger jobs on a fixed-cost basis. ANL does not prequalify their fixed-price construction contractors. They have three basic ordering agreement (BOA) contractors for small jobs $<\$ 50,000$ (general, mechanical, and electrical) and are very selective about using the BOA approach, because it is more expensive than the fixed-price contract approach.

They employ a minimal amount of ES\&H oversight. Safety is a line management responsibility, specifically that of the ANL project manager. Bouie says there are five people in his organization who provide advice and guidance on ES\&H, but the responsibility lies with the construction contractor's project manager. They issue tickets to the contractors, and if there are too many, the contractors are terminated or suspended. Only the project manager can shut down a job, unless there is imminent danger.

ANL's performance measures constitute scope, schedule, and cost, which they report once per month. The overall measures for the facility organization are schedule, cost, budgets, building assessments, energy consumption, vehicle usage, space utilization, and utility reliability.

Bouie has individuals who belong to several facility management-related organizations, including the International Facilities Management Organization.

ANL feels that the change in the ANL/DOE contract that allows the best commercial practices to be used has made all the difference. It has allowed them to simplify how they do business and get away from the many DOE orders. The Facilities Management Organization has no 8A goals specifically. They use minority contractors only when they are qualified. They have no issues or problems in this area.

\section{C.2.6 Lawrence Berkeley National Laboratory Video Conference}

On April 1, 1997, the ED\&C Reengineering Team conducted a video conference with LBNL. The LBNL attendees were Bob Camper, Head of Facilities; Bert Schleifer, Engineering Group Leader; Charles Allen, Project Management; and John Bowerman, Technical Services Group Leader. In attendance for ORNL were Ted Fox, Ed Krieg, Larry Kelly, Stan Frey, Joe Herndon, Tom Etheridge, Gene McNeese, Joe Setaro, and Ray Juras. 
The LBNL fully implements the Davis-Bacon Act. They have a fairly simple process in which they review each activity and determine whether it is subject to the Davis-Bacon Act. They use the DavisBacon Act explicitly to define construction. The DOE site office reviews only those cases that are determined not to be subject to the Davis-Bacon Act. The number of such cases is very small. They define construction by the Davis-Bacon Act and a California law called the Stull Bill. Under this law, all construction activities over $\$ 20,000$ must be subcontracted. In the case of painting, the limit is $\$ 10,000$. In January 1998 , the limit will be revised to $\$ 50,000$ for construction and $\$ 25,000$ for painting. The Service Contract Act is implemented by their procurement organization.

LBNL does their own construction and design contracting and does not use a construction manager. They use project managers and give them full responsibility for each construction project. Three approaches are used for construction.

1. General Contractor or specialty contractor

2. GSE contract labor

3. Can also do the work themselves

LBNL also has a cost avoidance/energy savings contract. They have not had a positive experience with this arrangement because it leads to haggling over the baseline and the savings. They are trying to develop an innovative basis for contract awards. They would like to base the awards, in part, on successful past performance.

For A/E contracting, they have to follow the guidelines in the Brooks Act. Primary selection is based on competence. Their project managers manage the $\mathrm{A} / \mathrm{E}$ as well as the construction subcontract. $\mathrm{DOE}$ exercises oversight of $\mathrm{A} / \mathrm{E}$ contracts and construction contracts. LBNL has regular meetings during the design process-the $A / E$, project manager, and customer try to develop consensus. One scientist is chosen as a lead contact to decide on the priorities and to serve as a point of coordination. They have trouble getting the scientists to stay within the existing project scope.

The method used for construction contracts depends on their work load. A different level of overhead is applied to construction. Their in-house overhead rate is $42 \%$ (this is an average consolidated rate). They have prequalified specialty contractors. Once they are prequalified, LBNL can use them in a sole source manner under certain circumstances up to a total project cost of $\$ 100,000$. These are one-year contracts that can be renewed three times. They use them for $\$ 2.7-2.8$ million of noncapital-type construction and 3.5 million of GPP, with the total construction around $\$ 20$ million/year.

Their shops are represented by local unions, but they operate in an open-shop manner. They have a threeyear contract with a no-strike clause. The major issue they have with the unions is whether their subcontractors pay Davis-Bacon Act wages.

They have $8 \mathrm{~A}$ goals, but they feel many of the small business are not qualified to do complicated construction projects. They feel many are only qualified for commercial-type construction, which they do assign to 8As.

They have a relatively small engineering organization with about 40 people, and most of these staff charge to projects. They charge out at rate of $\$ 80 / \mathrm{hr}$. They also subcontract to handle shifts in work load. 
They don't use many performance measures at present but will increase their use in FY 1998. This is an area in which they are trying to improve. Their performance measures include real property management, planning, program management, maintenance, and energy use.

Safety is a big issue. The LBNL project manager is responsible for everything. There is a separate set of project inspectors (who report to Bob Camper). One is a construction safety inspector, which is a fulltime job, who reports to the chief construction inspector.

They deal with work involving special hazards separately from their construction projects; for example, for asbestos they use specialty contractors to make the site clean. Other specialty hazardous materials contractors are used to provide the construction contractor an environment that is safe and clean.

ES\&H oversight is provided by LBNL and their subcontractors. DOE oversight is infrequent, but DOE does a walk-through inspection once a month. They can do surprise inspections, but that doesn't happen very often. Their crafts do not have direct ES\&H oversight; oversight is provided by their supervisors and construction safety inspectors. They sometimes have a problem with DOE addressing safety with subcontractors directly.

LBNL are members of the International Conference of Building Officials, Construction Specification Institute, but are not members of the Construction Industry Institute. All of their engineers are registered professionals, and they stamp their drawings.

They use a prioritizing process to establish GPP/GPE projects, which entails a list of projects from division/infrastructure units. The Director's Action Committee then generates and prioritizes two lists-a noncapital list and a GPP list.

Overall they feel very good about their system and their relationship with DOE. According to one staff member, "We ask DOE what they want done, and then DOE lets us do it." They feel they have DOE's trust and are given authority and responsibility. This has been a difficult condition to establish that took several years to accomplish.

\section{C.2.7 Trip Report of Tom Etheridge to Lawrence Berkeley National Laboratory, April 21, 1997}

Tom met with Charlie Allen, supervisor of the Project Management Group; Bob Camper; Bill Wu, Small Projects Group; Bert Schleifer, Engineering Group Leader; and Chuck Axthelm, the Facilities Financial Officer. The LBNL is located above the University of California, Berkeley campus. The terrain is extremely hilly, which increases their operations and construction cost.

Bob Camper is responsible for both engineering, construction, and plant maintenance, including transportation. All of these functions are mutually supported by the ED\&C organization. Bob, who is two levels below the Laboratory Director, reports to Dr. Berkner, the Deputy Director for Operations, in a reporting relationship very similar to that of the ORNL Engineering and Construction Management Division through Dr. Swanks. The Small Projects Group supports mainly the P\&E-type functions and is colocated with the maintenance forces. They basically cover all work under $\$ 50 \mathrm{~K}$. They are a nononsense, limited-documentation engineering resource. Bill Wu heads up this group, which includes about eight people from all the basic disciplines, including architectural. Camper's organization consists of about 300 people, with 35 people in the Project Management and Engineering Groups. The Project Management Group carries about $\$ 50 \mathrm{M}$ under contract at an annual work load of roughly $\$ 10 \mathrm{M}-\$ 15 \mathrm{M}$. Their engineering/project management organization is larger than that of ORNL. 
The LBNL project managers (PM) are responsible for projects from cradle to grave. This includes all engineering, construction, and turnover. The PMs function in a much broader role than we use PJs at Oak Ridge. All construction is managed by the PMs. LBNL procurement awards the construction contracts, but the PM serves as the construction manager. A PM will normally use a construction inspector, a project administrator (our project analysis), and an estimator to manage all projects. They use the engineering design disciplines as required. If the projects are designed by an $\mathrm{A} / \mathrm{E}$, then the Title $\Pi I$ is performed by the A/E. All change orders, invoices, schedules, submittals, and other contract administrative functions are carried out by the PM's designated support team. This appeared to me to reduce the larger number of hand-offs we seem to experience. All project team members charge out their time to the projects.

All facility design, engineering, and construction come through the Facilities Department, which, according to Charlie and Bert, was not always the case. Several divisions in the past had attempted to plan their own facility modifications. This caused several problems for LBNL with configurations management, DOE, and overall efficiencies. Bob Camper has convinced senior management that for the good of the LBNL, all facility work needs to be pursued consistently. Dr. Berkner came out of the research side of LBNL and has fully supported this concept.

Work Input-LBNL has a central work request center for all facilities/engineering-related work. Everything from changing light bulbs to initiating a $\$ 50 \mathrm{M}$ line item goes through this work request center. Work input is assigned a unique number and is tracked by the work request center from initiation to completion by this small group of three people. For larger capital and noncapital projects, LBNL uses a general annual call to divisions similar to that used at ORNL. The requests are prioritized by LBNL management. The work request center is a part of the estimating group. The work request function is the only function carried on LBNL overhead.

Relationship with DOE-Effective 4/1/97, LBNL has one point of contact with the Oakland Operations Office for engineering and facilities-type work. Five years ago, the DOE Operations Office had almost a one-to-one assignment of DOE project managers to LBNL project managers, which sounds a lot like what we have had in the most recent past in Oak Ridge. Their current arrangement is to work closely with the LBNL-site DOE staff. This has been a much better value-added arrangement. LBNL met with the Oakland Operations Engineering staff about five years ago (when Camper arrived) and worked through a new arrangement to reduce the one-to-one ratio. Over the past five years, the DOE staff has been reduced, and within the past year, the most drastic changes have occurred. The Oakland office still controls the money that flows to LBNL, as well as to LLNL. LBNL has fully implemented Life-Cycle Assessment Management (LCAM) and reports using performance measures negotiated with the site office staff. I have a copy of their most recent LCAM report. The PMs make monthly presentations of their projects to the senior engineering staff and to DOE. The four-page status reports are similar in content to our IDR but are much more concise. Lowell Eli and John Yates are the primary contacts at DOE-HQ. Eli has been giving LBNL a lot of grief over their ED\&I costs in their critical design reviews (CDRs). LBNL had a validation on April 22 and was expecting to have to defend those costs. In the past, LBNL spent time each year visiting Yates at HQ, which seemed to pay off. Over the past few years, there have been fewer visits to HQs, and support from Yates has decreased. Charlie Allen felt the visits were of some use; however, the decreasing amount of available money may also have led, in part, to the decreased support.

Construction Safety-LBNL has had a recent incident involving a fall on the Genome project construction. They had problems in the past with FPSC safety. They are currently working with ANL to incorporate safety requirements language into their construction specs. Argonne has done this 
successfully. LBNL's desire is to make safety record/past performance a part of their selection process on awarding new construction contracts. They have not done this yet. It may be an issue with the low-bid process that procurement uses. LBNL construction contractors come from throughout the Bay area and operate with different safety requirements. Some commercial firms require that there be no accidents, while other clients don't care about the safety of the construction work force, just production. The contractors know what they can get by with, and they comply with those customers who require a lot of safety. Organizationally, the ED\&C group has a safety representative who works with the construction inspectors and advises them of safety issues and concerns. This person reports to the ES\&H side of the operations but works with the construction inspectors. The ES\&H staff provide job hazards analysis to the PMs as required by the PMs. The PMs are responsible to the LBNL for their projects, including all ES\&H requirements. The PM determines the needs of the project and defends the graded approach used on each project.

Policy and Procedures-Both the PMs and the designers have a policy and procedures manual. The manual was prepared within the last few years and is basically a result of the Tiger Teams visits. The manuals are used but need to be updated to reflect the new relationship with DOE. They do not have an LCAM manual, nor do they see the need to have one.

Coordination with Other DOE Labs-LBNL meets about twice a year with LLNL and Los Alamos to see how they are doing business. They feel these meetings are essential to keeping up with their own business. Camper also meets at least annually with other DOE Lab facility managers. He spent last week at Fermi at a FM conference. Jerry Hammontree, Director of ORNL Plant and Equipment Division, also attended.

Staffing-Their staffing is stable with low turnover, though they do get competition from the other universities and municipalities in the Bay area. I obtained copies of their position description for PMs. They train their PMs in contract administration and project management. They do not have a specific training program. The University of California has training in these areas, which is easily obtained. The PMs do have safety training specific to their projects. Individual PMs are assigned to specific divisions to provide support. This has proven to provide better support to the divisions. Each PM carries about six to eight projects.

Estimating-There are five full-time people. They support both engineering, construction, and maintenance tasks and also operate the work request center. Their primary estimating tool is the electronic version of Means. They find Means to be very accurate when the regional cost factors are applied. The senior estimators provide all CDR estimates. LBNL also uses some subcontracted estimates to support larger projects.

Accounting-All engineering labor carries $41 \%$ payroll burden, $16.5 \%$ engineering support burden, and $26 \%$ site support burden. A $\$ 30,000$ effort cost equates to $\$ 62,092$ in total engineering support labor (that's about $107 \%$ total overhead). I have a copy of their capital construction and capital-equipment project CAS examples and the Berkeley Lab forward pricing rates. One big difference is that they charge a standard rate for each discipline. They do not have a single engineering rate.

Construction costs-The rough cost per square foot (SF) data were given to me as follows: new construction, including all utilities and site preparation runs about $\$ 500 / \mathrm{SF}$ for scientific facilities; space renovated to become laboratory space is $\$ 300-\$ 350 / \mathrm{SF}$; renovations for office space run about $\$ 150 / \mathrm{SF}$. Their Genome facility is costing about $\$ 595 / \mathrm{SF}$. 
As-Builts-They follow standard engineering practice of getting as-builts from construction through the A/E in AUTOCAD v.12/13 format. They track all drawings using a system called Automanager Work Flow. They spent about three years getting this system established. They archived 13,000 legacy drawings onto microfiche at a cost of $\sim \$ 20 \mathrm{~K}$. Their records group has purchased their own microfiche machine, which is proving to be very cost-effective. They also developed a CAD manual which documents their system. They spend about $\$ 200 \mathrm{~K}$ annually to keep their AUTOCAD system and asbuilts up to date. This includes system upgrades and "vectoring" or dimensioning legacy drawings as they are needed. The electronic copies of the legacy drawings are not dimensioned. The "vectoring" process digitizes the drawing such that the dimensions become active and can be changed; otherwise, the drawings are just images. Procedurally, they follow the DOE records management process.

Site Planning-LBNL has a small three-person site-planning group; one person (Laura Chen) focuses primarily on facility planning, another on project planning, and the third on space management. Both short- and long-range site planning is performed. This office also manages the space charge-back system. LBNL has a variable charge-back system. I did not get the details. They are getting ready to double their rate and have a target of about $\$ 15 / \mathrm{SF}$ in about three to five years. This system is about three years old and has been very effective. They have only had one problem with a researcher who threatened to move his laboratory to the Berkeley campus if charged for the space. When they found out that the University of California had no space for this particular individual, they stopped being concerned about it. The longterm plan is to include in the charge-back cost those specific services used by the facility. I have the name of the site planning person if additional information is needed.

CDRs-On an average, a CDR costs $\$ 20 \mathrm{~K}$ and a detailed CDR runs about $\$ 60 \mathrm{~K}$. Their success rate on funded projects is a little less than 50\%. They were validating two projects on April 22 and expected to get one funded.

\section{C.2.8 Brookhaven National Laboratory Video Conference}

On April 9, 1997, we conducted a video conference with the BNL. In attendance from BNL were Mike Schaeffer, Manager of Engineering and Construction Services Division; Dave Dale, contracts specialist; and Marty Fallier, Head of the Project Coordination Group. In attendance from ORNL were Ted Fox, Ed Krieg, Ray Juras, Brad Patton, Steve Burnette, Joe Setaro, and Larry Kelley.

BNL makes a recommendation regarding Davis-Bacon Act applicability on all of their jobs and forwards their recommendations to DOE. They do not review routine maintenance, but special maintenance jobs, like reroofing, are routed for review. DOE makes the final determination on all of the jobs, but $99.9 \%$ of the time they follow BNL's recommendations. In practice, DOE does not review jobs having a total cost of $<\$ 20,000$. The Davis-Bacon Committee meets once per week. Their in-house forces do not do any construction activities except those that are exempted (these are the ten or so activities that are listed in the DEAR).

Brookhaven has no project labor agreement with regional construction crafts; however, their on-site craft is unionized. They have several unions with whom they deal. They have had an occasional strike, but they have been able to work around them. They do not have a construction manager; instead, they manage their own construction contracts. Once in a while they will hire additional subcontracted management support. Their design staff is 15 people, project management staff is 10 people, and construction inspection is 7 people. The total is about 40 people. They have many bidders on construction jobs, usually six or more. Their charge-out rate is about $\$ 77 / \mathrm{hr}$ without lab overhead. Their 
lab overhead is $6.6 \%$ for in-house design work and $12 \%$ for $\mathrm{A} / \mathrm{E}$ services and lump-sum construction contracts. These rates are expected to increase in FY 1998.

The cost of a standard office building constructed at Brookhaven would run for $\$ 125$ to $150 / \mathrm{sq}$. ft. For a laboratory, the cost is $\$ 200 / \mathrm{sq}$. $\mathrm{ft}$. They just completed a 12,000 -sq. $\mathrm{ft}$. two-story brick building that is about half laboratory space and half office space for a cost of $\$ 2.5$ million. The design was done by an $\mathrm{A} / \mathrm{E}$ that they have under a task-order agreement. They have ten firms that are under this task-order agreement.

They also use basic ordering agreements with contractors for basic building trades, including decontamination. They can use these contractors for anything under a total cost of $\$ 250,000$. They are also going to prequalify all bidders above the $\$ 250,000$ limit. They have contract labor agreements, two of which are set aside to $8 \mathrm{~A}$ contractors-painting and carpentry. This limit was expected to be raised to $\$ 500,000$ in November 1997. All of their contracts are fixed price. They hire Davis-Bacon Act labor and manage them directly. They use them on "fast track" maintenance and construction activities that are considered Davis-Bacon Act work. They have a contract for each trade. They have a task order for roof repairs and repaving. These are competitively bid for the lowest hourly rate. These two-year contracts have ceilings of about $\$ 600,000$, except the ceiling for work by the electricians, which is $\$ 3,000,000$. Five to ten percent of their work is done via this approach. About two weeks is required to make an award via the BOA approach. For a larger job, it takes about three to four weeks. They really think the BOA approach is efficient and timely.

They do about $\$ 20$ million per year in plant construction. This includes line items, GPP, and what they refer to as special maintenance. They provide monthly and quarterly reports on any projects over $\$ 300,000$. They have about 30 jobs ongoing in this category.

They use several measures of performance which are also part of their contract. They measure on-time performance, completion of GPP jobs on time, completion of line-item milestones, effectiveness of obligation of money, and comparison of actual with planned costs. They have some people who belong to the Construction Management Institute, but BNL does not have organizational membership.

They have not embarked on a shared energy savings program. They are very skeptical of this type of contract, which they feel would be very hard to manage and estimate the actual savings.

They do several things related to benchmarking: (1) they attend the DOE facility managers' meetings, where a lot of data is shared; (2) they have been looking at university association data; and (3) they have been looking at data from the National Institute of Health.

Their GPP program is about $\$ 5$ million per year. Engineering is about $14 \%$, overhead $6.6 \%, \mathrm{~A} / \mathrm{E}$ is $12 \%$. Their GPP is prioritized by BNL management. They maintain a GPP backlog list which currently is about $\$ 20$ million. Roofing is a major problem for them. The cost of reroofing is about $\$ 7 / \mathrm{sq}$. $\mathrm{ft}$.

They do not lease any facilities. They are going to a space charge-back system. They are looking at a three-tier system: laboratory-office, dry lab-shops, storage (\$3-\$10). This will cover the maintenance activities of the lab. 
They have many hazards. One particular area of concern is contractors who violate rules and get contaminated. They are revising how they work around contaminated areas and are not using general contractors. They also have had concerns about electrical safety. They have been criticized over issue prioritization stemming from the tritium problem. They have a 2 -hr contractor and subcontractor training requirement prior to the initiation of any work.

The contractor is responsible for safety on his job site. This is part of his contract. The BNL project manager oversees the work. They have two full-time construction inspectors. About five people in plant engineering can provide advice, one of whom is involved full time on construction inspection. DOE has two people who are involved with construction oversight. DOE conducts periodic oversight, and there are periodic audits by headquarters. The state of New York focuses on environmental issues.

In regard to design, if they have the capability, they usually do it in-house. There is a separate environmental cleanup organization that operates in a manner very similar to Schaeffer's group at a comparable budget.

In general they are very satisfied with the way they do engineering design and construction. They think their in-house design is as good or better than the subcontractors. They seem to do well by all of their performance measures. Their site office is small, about 40 people.

\section{C.2.9 Pacific Northwest National Laboratory Video/Teleconference}

On April 13, 1997, the ED\&C Reengineering Team conducted a telephone conference with the PNNL. The PNNL attendees were Marv Olson, Manager of Facilities at PNNL; Dan Rutherford, Contracts Manager; Carla Gather, Facility Planner; Perry Moore, Administrator of Engineering Services; Craig Parker, Manager of Labor Relations; and Chad Henderson, DOE Site Representative. In attendance from ORNL were Ted Fox, Ed Krieg, Larry Kelley, Stan Frey, Tom Etheridge, Gene McNeese, Joe Setaro, Ray Juras, Steve Burnette, Tony Medely, Jim Mathys, and Del Morgan.

Battelle Northwest operates the PNNL and a private companion laboratory. Battelle Northwest is a very unique organization in which privately and publicly funded work are combined in the same facility. They have privately owned facilities in Richland, Washington, and DOE-owned facilities a mile or so away on the Hanford site. They fully implement the Davis-Bacon Act for any construction-like work on the Hanford site. At the private site, the Davis-Bacon Act does not apply. Any work that is suspected to be covered by the Davis-Bacon Act is sent to the DOE site Labor Standards Board for determination. They send five or six projects per week. They remarked that about $10 \%$ come back categorized differently from how they were originally. They define construction by the Davis-Bacon Act.

Fluor-Daniels (FD) has the operations contract for the Hanford site, which includes construction. All Davis-Bacon work is managed by FD. All infrastructure responsibilities at Hanford belong to DynaCorp, a subcontractor to FD. PNNL has about 3800 staff, and FD has about 10,000. There is a Hanford Site Stabilization Agreement that is essentially the same as our PLA. This agreement is only for activities on the Hanford site. It is the result of labor unrest in the late 1970s and early 1980s. FD has a subsidiary that can do construction and manages the construction contracts. Almost all of their construction contractors are local, and the labor comes from the local union hall. Their PLA appears to be even more restrictive than the Oak Ridge PLA. The contractors cannot use any of their own craft labor. Contractors out of the area hear about the agreement and don't bid. PNNL says they work closely with the on-site construction manager. PNNL provides its own project manager who oversees the work. Their private laboratory facility in Richland does not operate under a PLA. About $85 \%$ of the work at these facilities is for DOE. 
FD uses both fixed-price and cost-plus contracts. Cost-plus contracts are used for smaller jobs. They estimate about $60 \%$ fixed-price and $40 \%$ cost-plus contracts. They have done some design-build contracts. Some of the smaller design jobs are done in-house. Their design contracts were held by DOE three years ago; now they are contracted through the construction manager. FD has 55 craft who can be used for construction projects. The government side through FD tried to use a prequalification process. There was a lot of complaining by the local contractors, so the practice is on hold. The estimated cost of office space is $\$ 110-\$ 120$ per sq. $\mathrm{ft}$.

The ES\&H responsibilities are assumed by the construction manager. PNNL is only responsible for their own employees. PNNL provides health physics support.

They operate their private facilities differently. They design either in-house or through a subcontracted designer. They access most of the construction contractors via a BOA. They can use their own in-house forces for construction and, in fact, have an agreement with their union that gives them first right of refusal on a construction job. Their engineering design organization has about 50 people. On the private side, they do use prequalification. They have a BOA with several general contractors they use on a costplus basis, and they have a list of contractors who they go to for fixed-price bids. They do not use a labor-hour contract; instead, they use their own in-house force for quick turnaround jobs. Battelle provides about $\$ 1.5$ million per year in construction capital. We gather, since they are nonprofit, this money comes from their fee or overhead. They use a space charge-back system, which is $\$ 25-33 / \mathrm{sq}$. $\mathrm{ft}$. They have no $8 \mathrm{~A}$ quotas and only use $8 \mathrm{~A}$ contractors for small, low-risk projects.

They prepare only one document, a project management plan, that provides requirements for construction projects (line item and GPP). This document encompasses the requirements of the conceptual design report and the systems requirement document (SRD). Site planning is performed by the subcontractor to FD.

For a typical construction project, about $50 \%$ of the total cost goes toward construction.

Performance measures have been included in their contract for the first time this year. Fifteen performance measures have been included as part of the LCAM initiative.

\section{C.2.10 Lawrence Livermore National Laboratory}

On May 14, 1997, a team from LLNL visited ORNL. Their team consisted of Patrick Dempsey, Deputy Division Leader, Design and Construction Division; Roy Neyer, Division Leader, Projects Division; and David Johnson, Director, Electric Utilities Division. The purpose of their visit was to try to improve what they believe is a pretty good system for doing ED\&C. They are visiting other laboratories and private industry in an effort to find ways to improve their procurement methods and fine tune their ED\&C system.

LLNL has 7600 employees with facilities that are located on 840 acres. Because the site served as a naval air base during World War II, the site is now contaminated with chemicals, mostly solvents such as trichloroethylene. As a result, LLNL is a superfund site.

They do both in-house design and subcontract with $\mathrm{A} / \mathrm{E}$-the choice is up to the customer. They hold all of the A/E contracts. They generally use A/Es to balance the load with their in-house staff to address peak design needs. 
Davis-Bacon Act review is done by one person. They have few or no Davis-Bacon Act issues.

They act as their own construction manager and both perform and manage construction. They have several ways of doing construction and have recently changed their procurement practices. They used to be a Federal Acquisition Regulation (FAR) contractor, but they are now a best-practices contractor. They mostly do fixed-price contracts, selecting the lowest-cost, best performers. They feel they have excellent competition and can select competent and good-value contractors.

They can also use labor-hour contracts. They buy the materials and provide the equipment; the subcontractor provides the labor. They can also use their own staff for construction projects up to a total cost of $\$ 20,000$. Like Lawrence Berkeley, they are limited by California's Stull Act. The labor-hour contract is limited to $\$ 6,000,000$. While they have no PLA, the labor-hour contract staff are all hired out of the same union hall and tend to be the same people. This is because they all have clearances. They do have a PLA for the National Ignition Source. Their maintenance organization also hires temporary contract help.

In the past, they mostly used small businesses and minority-owned businesses; they can now go to the best source. They now prequalify contractors and track performance. They do use some construction contracts to meet the disadvantaged business criteria, which are competed for among their $8 \mathrm{~A}$ contractors. Under the previous quota-driven system, some small businesses were driven into bankruptcy when these businesses contracted for projects that were beyond their capability.

They have considerable oversight from their ES\&H staff. They feel they are over-regulated, which is a remnant of the Tiger Team days. They hope to correct this problem.

They do not have comprehensive configuration control. They do well on large jobs, but smaller job are not as well documented. They use a few performance measures, such as percentage of jobs on budget and percentage of jobs on schedule. They don't see that performance measures have been that useful.

\section{C.2.11 University of Tennessee}

On April 15, 1997, Ted Fox, Ed Krieg, and Tom Etheridge met with George Criss, Head of Facility Planning, and Charles (Al) Payne, Executive Director Capital Projects. They have a staff of eight people, which includes engineers, architects, and clerical staff. Their job is to plan and manage all construction projects for the university system, including UT-Knoxville, UT-Chattanooga, UT-Martin, UT-Memphis, and the UT-Space Institute, as well as several assorted remote sites.

The authority for construction comes from the Tennessee Building Commission. There is a capital budget cycle in which capital improvements are identified, and Criss's staff submits a budget. Capital budget hearings are held that include all campuses. The budget is approved by the commission. The commission also selects the designers and the contractors based on Criss's recommendation. They usually select $\mathrm{A} / \mathrm{Es}$ and contractors who are local to the construction area. They have no minority-owned or small-business requirements. They only select contractors on the basis of the lowest bid. The only requirement is that the contractor be licensed and provide a 5\% bond. Designers are paid a percentage of the estimated cost of construction based upon the size of the project. They add a 1.25 multiplier for renovations. Occasionally they will enter into an hourly agreement for design work. They have blanket electrical and mechanical contracts that they can draw upon at any time. 
While they don't have to comply with the Davis-Bacon Act, the state of Tennessee requires that all construction contractors pay prevailing wages, as established by the Department of Labor. This is not an issue with them since they do not get involved with the labor arrangements of their contractors. They do not use a PLA and see no value in one. In fact they make a point of staying out of the means and methods of their contractors. Their philosophy is that they select the lowest-cost contractor and assume that they know how to do their business. The University exercises no safety oversight over construction contractors. The contractor is totally responsible for safety.

They feel theirs is the most efficient and cost-effective approach, and they get excellent value. This is exemplified by their new Engineering Science Building at UT-Knoxville. It is a 210,000-sq. ft. laboratory that cost $\$ 24$ million to build ( $\$ 114 / \mathrm{sq}$. ft.). It should be noted this was a difficult building site.

When they are in the design phase, they work very closely with the users. A facilities management organization represents the users and chairs a committee that defines the requirements. Once under construction, the users have little or no involvement.

\section{C.2.12 Arnold Engineering Development Center}

June 12, 1997-Telephone Discussion with Leo Ponder, ACS, Arnold Engineering Development Center

The AEDC does not do any Davis-Bacon Act screening. It is not believed to be an issue since they pay their own labor more than Davis-Bacon wages. They use their own in-house forces for construction up to a total project cost of about $\$ 200,000$. However, they require their contractors to pay Davis-Bacon wages. This is routinely included in their contract language.

ACS, a joint venture of Computer Science Corporation, Dyncorp, and General Physics, manages the AEDC infrastructure. ACS does not use a construction manager. They have a staff of about 10-12 project managers who oversee all of their construction projects. They do about $95 \%$ of their design inhouse. They have no $8 \mathrm{~A}$ set asides for either design or construction contracts. Their minority-contracting goals are met through a variety of ways.

They do not use prequalified contractors. Rather, they open-bid all of their construction contracts, and there is a fairly constant pool of bidders. They feel they have healthy competition. They do not use a labor-hour contract approach; only fixed-price contracts are used.

They have no PLA, although the local unions would prefer that. They have had labor problems from time to time, particularly when they have non-union labor on the job. It doesn't seem to seriously affect them and doesn't influence their business decisions.

\section{June 24, 1997-Telephone conversation with Mark Kelley of Sverdrup, AEDC}

The AEDC is owned and managed by the U.S. Air Force. They have approximately 150 military and 200 civilian civil service employees on-site. There are two operations support contractors: ACS, who operates the facilities and infrastructure, and Sverdrup, who runs the test facilities. The engineering design can be done in a number of ways. For small infrastructure jobs, ACS performs the work; for experimental, Sverdrup does it. For large construction jobs, the Corp of Engineers may do it, or they may hire an $A / E$ on a fixed-price contract. They do not use time and material contracts. 
In a similar manner, small to medium construction is handled by ACS for infrastructure facilities and Sverdrup for testing facilities; they often use their in-house staff. They do not worry about Davis-Bacon Act considerations because the wages of all their staff exceed Davis-Bacon wages. All site construction procurement is handled by ACS or through the Corps. They have no private construction manager. However, the Corps of Engineers manages the large jobs. All of these decisions are made by the Air Force. There is no PLA. There was an agreement between SSI, ACS's predecessor, and the Nashville Trades over special jobs, but that agreement was not renewed by the new contractor. They do not use a labor-hour contract since they can use their own craft for construction.

Mark said they have an anomalous but excellent working situation. He feels the Air Force management makes all the difference. He said the Air Force management and contracting officers are the best construction and facility people he has ever worked with-highly professional and technically competent.

\section{C.2.13 National Renewable Energy Laboratory}

The following information was provided by Mike Glaser of NREL during a telephone conversation with Ted Fox on June 18, 1997.

NREL uses neither a construction manager nor a PLA. They have never seen the need for either. They do not do any major in-house design. They limit their in-house design work to jobs that require less than $60 \mathrm{hr}$. NREL does not use time and material contracts. However, they do prequalify their design contractors. They do not use 8A set aside even though they were pressured to take on some of the minority businesses when the airport project was completed in Denver. These businesses were shown not to be qualified. Minority businesses are used for a few special jobs.

They contract all of their construction. They do not use a labor-hour contract approach, but they do prequalify their fixed-price construction contractors. While they have no 8A set asides, almost all of their contractors are small businesses.

The following are written responses from Mike Glaser of NREL to benchmark questions on March 25, 1997.

1. Do you have a summary process description for executing construction projects?

In a sentence, NREL has fully implemented the LCAM order as it applies to construction projects. We design to the governing building codes and manage the projects using standard industry and best business practices, including graded approach to risk management.

We have a handbook that provides guidelines for our project team members. This manual is currently being revised to match a major Laboratory reorganization that took place in FY 96.

Facilities and selected research support construction projects at NREL are performed primarily by project teams led by a dedicated Site Operations Center project manager utilizing matrixed NREL team members representing the Golden Field Office, User, Procurement, Facilities Engineering, Maintenance, ES\&H, and Finance. Design and construction are contracted to local (Denver metro area) firms, and they report directly to the project manager. 
Working within a formal change control process based on a graded approach, the project managers have complete control of and are held directly accountable for the project scope, budget, and schedule baselines as approved in project specific project management plans.

Facility projects are the responsibility of the Site Operations Center Engineering and Construction $(E \& C)$ team leader, and the project management is performed by one of six Building Area Engineers (BAE). The BAE is responsible for all facilities-related planning, space utilization, construction, operations, safety, and maintenance for a dedicated set of buildings and support area and thus provides a central point of coordination and management of all area activities related to construction.

For research- and development-related construction that is similar to normal facilities-type work [i.e., HVAC, electrical ( $480 \mathrm{~V}$ plus) civil-structural, modifications, etc.], the Engineering and Construction team generally provides the project management unless work loads require utilization of the BAE. Again, the central point of responsibility is the E\&C team leader and if the BAE is not the project manager, they are, at the least, a project team member.

The philosophy of the Golden Field Office is that the $\mathrm{M} \& \mathrm{O}$ contractor is responsible, by contract, for the management of all construction projects and, as such, they have a "hands-off" oversight policy. As the $\mathrm{M} \& \mathrm{O}$ contractor, we maintain a high level of professional confidence from the Field Office by including one of their staff on all facilities-related project teams with projects having a total cost of over $\$ 200,000$ or with a high level of complexity. Their input is evaluated by the project manager in the same manner as any other team member. Any issue that could potentially be related to the $M \& O$ contract is not discussed in the team environment. In addition, the E\&C Team Leader holds a biweekly status meeting that includes the Field Office and NREL ES\&H representatives and project managers and a monthly status meeting with the Field Office and NREL upper management. As a result, NREL has an excellent working relationship with the Field Office, and it could be best described as "non-intrusive." Needless to say, our historical (last four years) of successful construction project performance is a major contributor to this philosophy.

The primary function of the Facilities Engineering group is to provide configuration control of the Laboratory's technical baseline. As such, the in-house engineering resources are used primarily in the support of the development of the conceptual designs and as a quality control function during the formal design reviews and construction acceptance inspections.

The project manager is responsible for the ES\&H aspects of the project and uses the appropriate ES\&H representative in a consultant mode only.

The A/E contracting is under a three-year task order contract with the firm selected under the competitive best-value selection process. Detailed design task orders (Title I \& II ) have a design-tocost requirement that holds the $\mathrm{A} / \mathrm{E}$ responsible for providing the appropriate scope for the cost identified in conceptual design. This has resulted in excellent cost management of our projects from a design perspective.

The construction contractors are selected on a competitive firm, fixed-price basis for each project. We have used a competitive best-value selection process for work that may be overlapping due to phased funding where we get a firm fixed price for the first phase of work and negotiate fixed-price follow task orders based on the rates established in phase I for remaining phases. 
For both the $\mathrm{A} / \mathrm{Es}$ and construction contractors, we maintain a closed short list of firms with which we have had successful experiences.

2. Did you reorganize and were you able to identify project management costs by type or size of project.

Yes, we did reorganize right after our meeting and again last year. For the last three years, our project management cost on facilities projects over $\$ 1,000 \mathrm{~K}$ is running at $4 \%$ of TPC. It is slightly higher on projects from $\$ 100 \mathrm{~K}$ to $\$ 1,000 \mathrm{~K}$. We don't normally collect these costs on projects smaller than $\$ 100 \mathrm{~K}$, but we do budget $4 \%$ and we have made that work so far.

Our project management costs for research support projects are anywhere from $4 \%$ and up. Scope management caused by our state-of-the-art R\&D environment is tough for us to control. However, our research programs are happy with our work and keep requesting additional support. Our portion of most $R \& D$ projects is rarely over $\$ 100 \mathrm{~K}$, although we do have a $\$ 2,750 \mathrm{~K}$ and a $\$ 600 \mathrm{~K}$ project currently in process.

3. How do you perform construction management?

The project manager directly manages the construction of each project by direct technical oversight of the construction contractor selected for each project. The project manager utilizes both the design agency engineers and architects and independent testing firms for quality control and a NREL contract administrator for contract management. We do not employ an independent construction manager or use a general task order contractor. However, we do use local construction estimating firms for support in providing independent estimates for planning purposes and verification of $\mathrm{A} / \mathrm{E}$ estimates in some cases.

4. Do you use fixed price contracts for construction?

Primarily. See \#1.

5. Do you use liquidated damages clauses in our construction contracts? If so, are they successful?

Yes, we do. We find that we have no trouble in recovering our actual damages resulting from delays caused by the contractor's lack of management. This has happen three times in the last four years. However, since it is in no one's best interest to have delays, the NREL project manager works directly with the contractor's project manager throughout the contract period to minimize or eliminate any delays. This is our most successful schedule management process.

6. Did you implement the safety incentive program for construction forces?

No. We could not see a cost-effective or uncomplicated method of implementing this proposal. What we did do is include only contractors who understand our safety program and with which we have good safety-related experience in our closed short list of perspective bidders. We will also shut down any contractor exhibiting safety problems, and thus they have a negative incentive due to potential liquidated damages. Last year we achieved zero lost time from accidents for $100,000 \mathrm{hr}$ of construction labor and have a similar safety record this year. We feel the key is having our project manager in or on the construction site at least daily taking a proactive safety attitude. This attitude is recognized and followed by our construction contractor superintendents and foremen. 
The safety problem that currently takes most of our effort is the indoctrination and management of first-time subcontractors brought on-site by the generals. We are working with Procurement on how to legally publish a list of subcontractors who we will not allow on-site for safety reasons.

7. Does design engineering run at $9 \%$ of total project cost?

Yes, $9 \%$ is the maximum cost for conceptual and detailed design on projects $\$ 1,000,000$ or larger. It is $1 \%$ or $2 \%$ higher on smaller projects because of a higher fixed-cost ratio.

8. Do you keep performance metrics for the engineering design and construction process? If so, could you share them for comparison purposes?

As part of our "balanced score card" currently used by the Field Office and NREL management to measure the success of our management of construction projects, we identify the individual and cumulated variances of our project baseline scopes, budgets, and schedules in an earned-value format. This is on a threshold basis only (i.e., $90 \%$ of projects are within $5 \%$ of budget, etc.). We are also measured on such things as percent of our project managers certified, engineers registered, projects followed proper change control process, etc.

As for sharing these matrices or any other information regarding or process, we would more than be happy to do that. However, I am not sure that we would be comparing two systems with the same requirements due to our size, work load, and ES\&H constraints: We do about $\$ 6,000 \mathrm{~K}$ of capital projects and $\$ 1,500 \mathrm{~K}$ of operating funded project per year. We have no radioactive or large amounts of hazardous materials to concern us, and we have an enlightened DOE Field Office. 


\section{C.3 DAVIS-BACON DETERMINATION (L.C. Kelly and B. D. Patton)}

\section{C.3.1 Introduction}

This subteam, as part of the overall reengineering effort of Engineering Design and Construction, was tasked to review the Davis-Bacon Act (DBA), the Service Contract Act (SCA), the Project Labor Agreement (PLA), the Construction Manager, and the LMER contract as they pertain to ORNL engineering design and construction management.

\section{C.3.2 Process}

This review consisted of investigating the processes used to implement these requirements, conducting personnel interviews, and reviewing regulations and contract language. The overall goal of this effort was to look at the processes being used to develop a set of recommendations that could improve the current way in which these areas are being implemented.

\section{C.3.3 Labor Standards}

\section{C.3.3.1 Davis-Bacon Act (DBA)}

The DBA is named for its chief sponsors, Senator Davis of Pennsylvania and Representative Bacon of New York. The stated purpose of the act was to end the importation of cheap labor to work on federal or government construction. The DBA, 40 United States Code Section 276a, was enacted on March 3, 1931, to require the inclusion of minimum wage rates for laborers and mechanics employed on the site of federal and government contracts for construction, alteration, and/or repair, including painting and decorating, of public buildings or public works. The act required that contractors and subcontractors working on federal construction contracts of $\$ 2000$ or more pay their workers no less than the prevailing wages earned by laborers in the same area on similar projects. Determinations as to local prevailing wages are made by the Secretary of Labor.

The Department of Labor (DOL) makes the rules and regulations and has the final authority on the DBA. Final authority means that DOL can reverse or change any ruling made if it is not consistent with the guidelines as set forth by DOL in the implementation of the DBA. Responsibility for the administration and implementation of the act is with the contracting agency, which in this instance is the DOE. The DBA itself is relatively brief and, in some instances, unclear as to definitions and what is meant. To alleviate this problem, the DOL in 1983 promulgated 29 CFR Part 5, to assist in implementing the act. The CFR defines construction as follows:

The terms "construction," "prosecution," "completion," or "repair" mean all type of work done on a particular building or work at the site ... all work done in the construction or development of the project, including without limitation, altering, remodeling, installation (where appropriate) on the site of the work of items fabricated off-site, painting and decorating, the transporting of materials and supplies to or from the building or work by the employees of the constructions contractor or construction subcontractor, and the manufacturing or furnishing of materials, articles, supplies or equipment on the site of the building or work ... by persons employed by the contractor or subcontractor. 


\section{C.3.3.2 Service Contract Act}

The McNamara-O'Hara SCA was enacted in 1965, and its purpose is to provide for the protection of employees of contractors and subcontractors furnishing services to, or performing maintenance service for, federal agencies. The SCA is applicable to contracts in excess of $\$ 2500$ for furnishing services through the use of service employees. Service employees are defined in the SCA as guards, watchmen, and any person in a recognized trade or craft, or other skilled mechanical craft, or in unskilled, semiskilled, or skilled manual labor occupations. Other examples of services furnished include food and/or cafeteria, custodial and/or janitorial, housekeeping, and laundry and/or dry cleaning. Persons covered by this act must be paid the prevailing wage rate. Determinations of the prevailing local wage rate are made by the Secretary of Labor. As in the case of the DBA, the DOL makes the rules and regulations and has the final authority on the SCA. Responsibility for the administration and implementation of the act is with the contracting agency, which is DOE.

\section{C.3.3.3 Labor Standards Implementation}

Implementation of labor standards at ORNL involves both LMER and DOE. The process utilized is described in LMES Procedure MA-101, "Application of Federal Labor Standards," and Course \#1624 training manual for "Application of Federal Labor Standards." Handout \#5 in the course manual, Labor Standards Review Process Flowchart, provides a visual representation of this process. It should be noted that this process is used for both the DBA and SCA and is briefly described as follows.

Three paths are generally followed to request services: (1) Requester of Engineering Services, (2) Requester of Maintenance Services, and (3) Requester of Site Service Subcontract. These requests are then placed on an Engineering Service Order (ESO) (Item 1), Maintenance Work Authorization (Item 2), or Purchase Requisition (Item 3), respectively. These documents are reviewed, respectively, by the Engineering Project Manager (Item 1), the Maintenance Planner (Item 2), or the Site Service Subcontract Coordinator (Item 3). A preliminary determination is made as to whether the work is covered or noncovered. If the work is determined to be non-covered, it goes either into the Work Order Control or to Material Control process for implementation. Work that is believed to be covered is sent to the Site DB Manager for review. If work is determined to be non-covered, it goes into the processes described above for implementation. If it is determined to be covered or an uncertainty exists as to its status, it is sent to the Site Labor Standards Committee for review. Covered work is sent to the DOE Labor Standards Committee for review. After the DOE Committee rules, the work items are returned to the Site Labor Standards Committee for disposition.

\section{C.3.3.4 ORNL Site Labor Standards Committee}

Jim Nook is the Chairman of the Site Labor Standards Committee. Time was first spent explaining the process described above. The following points are highlighted from our discussion:

- DOE and the LMES/LMER Labor Standards Committee have developed guidelines that allow the site to handle approximately $90 \%$ of the requests that are made. Those items that are sent to the DOE Labor Standards Committee are "gray areas" in which the type of work is not clear and tasks that are obviously construction and/or services work.

- The committee is composed of three people. There are two voting members from LMER and one non-voting member from MK-Ferguson (MK-F). 
- The labor unions, Atomic Trades \& Labor Council (ATLC) and Knoxville Building and construction Trades Council (KBCTC), review the committee rulings.

- On an average, eight requests per week are sent to the ORNL Site Labor Standards Committee for disposition. This does not include the estimated $90 \%$ of the total work requests (maintenance request) that are sent directly to either the Work Order or Materials Control Systems for processing. Of the eight requests, five, on average, are ruled on by the committee and forwarded to be processed. An average of three items per week are forwarded to the DOE Labor Standards Committee for a ruling.

- Provisions are in place to expedite rulings and to have emergency meetings, if necessary.

- DOE currently reviews past rulings on an exception basis.

- Complete description of the work is very helpful in ensuring the determinations flow quickly through the system.

- LMER is presently evaluating the possibility of making the process paperless.

\section{C.3.3.5 DOE Labor Standards Committee}

George Benedict, Harry Peters, and Bill Truex, members of the DOE Labor Standards Committee, came to talk to the reengineering team. A wide range of topics was discussed, including some of the following pertinent facts about Labor Standards:

- DOE has been granted authority from the DOL to make labor rulings. If that authority were taken away, all requests for ruling would have to be sent to DOL to be made.

- DOE reviews the work and makes rulings based on the following: (1) the DBA and 29 CFR Part 5, (2) case law, (3) DOL agency memoranda, and (4) past site practice. Items 1 and 2 are selfexplanatory. DOL agency memoranda are used to clarify Item 1 or to make unilateral decisions on a labor issue. For example, there was some confusion regarding the application of the DBA to the removal of asbestos and paint. To clarify this situation, on August 6,1990 , the DOL issued Agency Memoranda Number 153, which unilaterally stated that the removal of asbestos and paint is covered by the DBA. Past site practice is used when the DOL reviews how work has been accomplished in the past to help make a ruling as to how work will be accomplished in the future. For example, for the past 30 years, work has been done a certain way, but you now decide that it is more advantageous to do it differently. If the new method is instituted unilaterally, the union can file a complaint with DOL on this new method of accomplishment on the basis that you are violating past practice. The DOL will investigate and, in general, if a violation of labor laws and/or DOL guidance is found, they will issue an opinion or guidance memorandum. DOL will not review and issue an opinion solely on the basis of DOE past experience but will also consider their own experience.

- DOE-ORO is concerned with how labor issues can affect all of the facilities managed by DOE-ORO.

- DOE responds to numerous congressional and union inquiries because of Labor Standards rulings.

- The DOE Labor Standards Committee has worked with site labor standards committees to provide guidelines so that the bulk of the rulings (maintenance jobs) can be made at the site. However, it is 
the DOE-ORO position that ruling on the DBA- and SCA-covered work is the sole responsibility of DOE and not the contractor; it is the DOE-ORO position that the authority granted to DOL by DOL cannot be given to others.

- DOE is willing to discuss any changes proposed by LMER as to the current method of making of labor standards determinations.

\section{C.3.3.6 ORNL Labor Relations Office}

The following relevant points were made during an interview with Gerald Watson.

- KBCTC and ATLC are both affiliated with the AFL/CIO.

- If LMER had construction authority in its contract, ORNL would have to make decisions on whether work would be done by construction crafts or in-house maintenance crafts, within the confines of the Davis-Bacon Act. There is the possibility that the ATLC could file a grievance concerning the chosen method of accomplishment based on decisions by ORNL.

- In order to have construction authority in the contract, ORNL would have to develop a certified payroll to verify that DBA wages are being paid and to perform audits as necessary. All contractors have this type of certified payroll.

\section{C.3.3.7 Benchmarking Results}

The discussion below summarizes results obtained from benchmarking discussions, as they pertain to the DBA. To see the results of the entire effort, see the Benchmarking section of this report.

Six national laboratories were benchmarked to compare how each handles the DBA process. These national laboratories are ANL, BNL, LBNL, LLNL, PNNL, and Sandia. The results are as follows:

- All the laboratories, except Sandia, conduct internal reviews.

- DOE either reviews the results or is sent a portion of the DBA cases on which to rule. Generally, the internal contractor review process determines which are sent to DOE.

In general, the process used by the other laboratories is similar to what is being done at Oak Ridge, although DOE appears to be involved to a lesser extent at the other sites than at ORNL. The primary difficulty with the DBA process for ORNL stems from the requirement that all DBA covered work must be managed by a general construction manager, which adds significantly to the cost, particularly for small construction projects.

\section{C.3.3.8 Survey Results}

The entire survey results can be reviewed in that section of this report. The following are the pertinent conclusions drawn from the data provided:

- Incomplete information is the main reason forms are not ruled on initially, which results in a delay due to DOE returning the forms for more details. 
- Of the forms ruled on, approximately half (46\%) are returned because the ruling is not acceptable to the requestor. Generally, the requestor does not have adequate funding to complete project-ruled construction.

A survey comment seems to best summarize the conclusion of the team. "The ruling on Davis-Bacon is not the problem, the DOE-ORO Construction Manager requirement is the problem." Because people are trying to achieve a desired outcome, they are causing the system to take longer than necessary. Therefore, it is concluded that there is nothing significantly wrong with the process currently being utilized.

\section{C.3.3.9 Issues with Present Labor Standards Strategy}

At present, there do not appear to be major issues related to the process used to implement labor standards. It appears Oak Ridge is doing basically the same as other DOE laboratories, except for a somewhat higher level of DOE/ORO involvement. The issues relate to the Construction Manager Concept, which will be discussed later. It appears that the Site Labor Standards Committee continues to dialogue with DOE, and the guidelines that have been set allow the site to rule on maintenance activities. This has pushed the bulk of the needed rulings to a lower level. However, the process should be reviewed to determine ways to further streamline the process.

One system enhancement, going to a paperless process, should be considered. This may further speed the current process.

\section{C.3.3.10 Recommendation}

The majority of the team believed that the ORNL Davis-Bacon review process should be streamlined. Consideration will be given to the following:

- Change focus to determining whether construction crafts (Davis-Bacon wage rate) or in-house maintenance crafts are required rather than determining the implementing organization and the method of accomplishment.

- Utilize a web-based system for acquiring and disseminating project information, as well as the resulting determination on utilization of maintenance or construction labor.

- Move this function organizationally from the P\&E Division to the ORNL E\&CMD.

- Eliminate ORNL participation in the three-site Davis-Bacon Committee.

- The present DBA review process is perceived to be time-consuming, largely because of the inefficient construction management process available at $\mathrm{ORNL}$.

- Improvements to ORNL's ED\&C approach will eliminate a number of the perceived impacts of Davis-Bacon determinations. 


\section{C.3.4 Project Labor Agreement}

\section{C.3.4.1 Description}

In its simplest form, a PLA is a collective bargaining agreement between a company and generally union construction workers that sets forth their policies or agreement upon items such as wages, dispute resolution, working conditions, work rules, fringe benefits, etc. Generally, these agreements are noted for containing a no strike clause. The Oak Ridge PLA is an agreement between MK-F and the KBCTC. This agreement provides a framework that describes how construction work will be accomplished in Oak Ridge.

\section{C.3.4.2 Pro's and Con's of a PLA}

Historically, the reported major pro's and con's of a PLA are as follows:

\section{Pro's}

1. No strike clause.

2. Provides long term agreements on wages, working conditions, benefits, work rules, etc.

3. Contains dispute resolution clauses and agreements on employee termination.

\section{Con's}

1. Preference for union workers.

2. Increased project cost.

3. Stricter work rules that limit flexibility on assignments for individual worker.

4. Elimination of an experienced crew of company employees coming into the area to do work.

\section{C.3.4.3 DOE-ORO PLA}

The DOE-ORO PLA is between the general construction manager company, MK-F of Oak Ridge, and the KBCTC, AFL-CIO. It covers the areas of wages/benefits, work rules, grievance procedures, jurisdictional disputes, etc. It does contain a no-strike/no-lockout clause. This agreement has been in place since 1990. Prior to 1990, a PLA-type agreement was used that applied only to direct-hire work, which comprised about $30 \%$ of the overall construction work; the direct-hire work was done primarily in the Material Access Areas (MAAs) of the Y-12 Plant. Thus, utilization of a PLA beginning in 1990 represented a major change for ORNL. Under the present agreement, all subcontractors that are doing construction work on the Oak Ridge Reservation become a signatory to the PLA.

Several impacts result from the PLA; these include increased project cost, elimination of the more capable contractors who choose not to bid on our projects because of the PLA, ORNL losing its competitive edge with other DOE-energy research laboratories, and severe criticism from DOE-HQ management, including loss of funding for construction projects. 


\section{C.3.4.4 Interviews}

\section{C.3.4.4.1 MK-Ferguson}

The following key points were made during an interview was held with Frank Larvie, Warren Anderson, and Dick Wilkerson of MK-F.

- PLAs are utilized at Savannah River, Hanford, Idaho, and Rocky Flats (all large sites).

- PLAs differ, but they recognize historical past local practice. Some work rules observed in the PLA were in place prior to the MK-F PLA. Prior to MK-F, however, the PLA did not apply to subcontractors.

- MK-F sees the major PLA advantages as the following:

(1) No strike/no walkout/no slowdown clause

(2) Ensures a trained work force. This helped with the heightened ESH expectations in that there was a pool of trained people from which to draw. People coming in from the outside would have to train their people to the required standards.

- Wage increases are standardized and not negotiated every year. The DOL sets the wage rate for Oak Ridge.

- There could be possible political consequences from not having a PLA.

- MK-F does business in both union and non-union shops.

- The PLA was set up at the request of DOE.

- International unions set work jurisdiction, not local unions.

- The unions are willing to negotiate new working conditions.

- MK-F is meeting with the Industrial Relations representatives from all sites to determine what the sites would like to see in a new PLA.

- MK-F is working on an integrated labor strategy for Oak Ridge whereby labor unions and contractors can sit down and resolve issues without going to Washington.

- MK-F believes the "Four Key Personnel" clause is an item for negotiation and should be eliminated.

- If you have a person who works in different craft areas, you have to pay that person at the highest rate.

\section{C.3.4:4.2 Lockheed Martin Energy Systems, Inc.}

An interview was held with Dan Anderton, Joe Whitefield, and Gerald Watson in which the following key points were made: 
- PLA provides stability to the site. In the past, there have been numerous informational pickets, but these pickets have not interrupted construction activities.

- Without a PLA, you may have more grievances and arbitration.

- Site-wide PLAs are the current trend at large DOE sites.

\section{C.3.4.4.3 DOE-ORO Labor Standards Committee}

The committee had the following comments on PLAs:

- A PLA is in the best interest of DOE-ORO from a labor stability perspective. The prime contractors should get together and develop a site-wide labor agreement. This should include DOE direct contractors that are involved in construction activities.

- The prime contractors should negotiate with the Building Trades on making improvements to the PLA that would promote increased efficiencies. The prime contractors should get together and develop a negotiation strategy.

- There are other major issues that drive up the cost of doing work at DOE-ORO. The work process rules, documentation requirements, unclear roles and responsibilities, etc., should be evaluated to identify areas for improvement.

\section{C.3.4.5 Benchmarking}

The results are as follows:

- Among the DOE Energy Research laboratories, only ORNL and the government portion of PNNL use a PLA.

- The other labs feel a PLA is not needed and that not having one allows them allowed more flexibility in getting work done. They feel not having a PLA results in a large pool of bidders for construction projects and lower cost.

\section{C.3.4.6 Survey Results}

In general, the survey feedback did not favor use of a PLA. However, in most instances, the results can be viewed in their entirety by reviewing the survey results. Some of the more pertinent responses are provided as follows:

- $70 \%$ don't believe the PLA is essential for labor peace,

- $60 \%$ believe the PLA increases construction-contractor administrative costs,

- it was a split as to whether the PLA contributed to improved work quality,

- $80 \%$ believe the PLA provides peaceful settlement of labor disputes,

- $60 \%$ believe that the PLA work rules result in inefficiencies, 
- $56 \%$ believe that a smaller number of contractors bid on work because of the PLA,

- $60 \%$ believe that bid prices are increased because of the PLA, and

- $40 \%$ believe that a new PLA should be developed.

\section{C.3.4.7 Recommendations}

The majority of the ED\&C Reengineering Team believes that ORNL should not enter into a PLA; however, large complex projects should be evaluated on a case-by-case basis to determine whether use of a PLA is warranted.

\section{C.3.5 LMER Contract}

The LMER contract was reviewed to determine if it allowed the flexibility that would permit LMER to select and award A/E and construction contracts. As stated on pages 5 and 6 of Contract No. DE-AC0596OR22464, Part III, Services paragraph (iii), ORNL is responsible for providing construction services "for all programs and activities described in the Statement of Work. This includes construction of line item projects, general plant projects, operations funded projects, other capital projects including the acquisition of basic capital equipment in support of ORNL missions and associated support activities, other projects in support of all missions, and other projects as DOE and the Contractor shall agree in writing." Continuing, paragraph (iv) states "Engineering services shall be provided to support the programmatic missions of ORNL. This includes engineering services for operations, maintenance, construction, decommissioning, and demolition of facilities."

This contract language allows LMER to directly contract for $\mathrm{A} / \mathrm{E}$ services and construction. More details of contracting issues are provided in the contract section of this report.

\section{C.3.5.1 Interview with DOE Labor Standards Committee}

The DOE Labor Standards Committee stated that LMER would need to show that direct contracting for $\mathrm{A} / \mathrm{E}$ and construction services was cost-effective for the government. In addition, DOE would have to approve this change.

\section{C.3.5.2 Benchmarking}

The results are as follows:

- ANL, LBNL, BNL, PNNL, and LLNL use in-house design services.

- ANL, LBNL, and BNL use time and material design contractors.

- ANL, LBNL, and BNL use prequalified design contractors.

- LBNL use in-house construction labor.

- ANL, LBNL, BNL, PNNL, and LLNL use labor-hour construction contractors.

- LBNL, BNL, and LLNL use prequalified construction contractors, without limitation. 
The laboratories feel they had greater flexibility by being responsible for the design and construction services. ORNL could be more competitive with other DOE laboratories by having in-house construction forces.

\section{C.3.5.3 Recommendations}

ORNL should request, from DOE, the ability to select and award design and construction contracts directly. 


\section{C.4 RISK ANALYSIS/MITIGATION (J. N. Herndon and J. A. Setaro)}

\section{C.4.1 Overview}

Risk issues play a key role in the execution of ED\&C projects at ORNL. These issues are diverse and may affect cost, schedule, project success/viability, and even the potential future success of ORNL. ORNL should strive to manage ED\&C risks in a manner that is equal to the best in class for the commercial environment.

\section{C.4.2 Process}

The process accomplished the following:

- identified the key risk issues that serve as a barrier to successful and best-in-class performance of ED\&C at ORNL;

- used surveys of customers, engineering personnel, ES\&H professionals, and contractors to determine areas that need attention;

- performed focused one-on-one interviews of key senior management in areas identified as having high impact;

- recommended solutions to eliminate/mitigate negative risk barriers where this is possible; and

- proposed a methodology to implement risk management in a graded approach for those risk barriers that cannot be readily eliminated/mitigated.

Based upon this process, the following issues were examined and approaches for improvement were developed. Some of these issues were found to be better assigned to other teams, which addressed them in their areas of this report.

\section{C.4.2.1 Environment, Safety, and Health Issues}

Issue-ES\&H risks must be considered for any construction project. The questions of who is responsible, who performs oversight (and how much oversight is necessary), how much risk is acceptable, and how much training is needed (and who is responsible for seeing that the training is accomplished) must be addressed.

Plan-Estimates of costs were developed for ORNL performing such tasks versus outside companies performing them. The subteam defined each of the above issues, determined which of them were being addressed by the ES\&H Reengineering Team (to eliminate duplication of effort and to prevent conflicting approaches in the final reports of the two teams), and examined responsibility in the areas of Price-Anderson Amendments Act (PAAA), Defense Nuclear Facilities Safety Board (DNFSB), Lockheed Martin (LMER, LMES), etc. This is essential in order to determine how much risk is acceptable to the various parties. 
The following global questions were considered when examining this issue:

1. What are the responsibilities of the ORNL ES\&H disciplines in the area of construction?

2. What is the cost of ORNL furnishing ES\&H coverage versus contractor-supplied coverage? What risks does ORNL accept by assuming responsibility for ES\&H oversight in construction areas?

3. What are the risks of having an outside contractor assume such duties?

4. Are there risks in the area of PAAA? Are there possible nonrecoverable costs resulting from fines?

Surveys were utilized to collect information related to these questions (see Appendix C.I for details).

Results - The majority of end users (customers), project engineers, and contractors indicated that ES\&H oversight was excessive and added little or no value to the project. Contractors, in particular, felt strongly in regard to this issue, and $100 \%$ indicated that project cost is adversely impacted by the level of oversight at ORNL. In contrast, ES\&H personnel indicated that more oversight is needed. When investigating further, it was found that an excessive number of individual ES\&H groups have oversight responsibility/authority and that a reorganization of this effort could result in a more focused approach that would be both thorough and cost-effective. Table C.1 illustrates the percentage of survey respondents in each major area who had observed a wide diversity of groups performing ES\&H oversight.

Based on survey data, $55 \%$ of construction customers, $47 \%$ of project managers/engineers, and $100 \%$ of responding contractors feel that the level of construction ES\&H oversight is excessive at ORNL. Of the construction contractors, $100 \%$ believed that ORNL project cost is negatively impacted by ES\&H oversight, and $73 \%$ believed that project schedules are delayed. In contrast to these data, $71 \%$ of ES\&H oversight personnel responding indicated that ES\&H oversight is insufficient, and $80 \%$ believed that insufficient attention is given to ES\&H risk during project design. Communication and development of common mission objectives among these groups are clearly a problem.

As a followup to the survey data collected in the ES\&H area, detailed discussions were held with the ORNL Director of Safety and Health and with the directors of the Office of Safety and Health Protection (OSHP), Office of Environmental Compliance and Documentation (OECD), and Office of Radiation Protection (ORP). These interviews were held to increase overall understanding of the issues facing these key organizations, which presently provide the bulk of compliance-related oversight activities in the construction area. Following are the overall observations and conclusions of these interviews.

Up-front involvement of ES\&H staff in design and construction activities is sometimes less than desirable and is dependent on ORNL customers. In the OECD area, this contact usually comes through the NEPA process, and with ORP, it tends to come through the complex leader or the ALARA program. For DOE-EM-funded projects that are executed at ORNL, the primary avenue for up-front involvement is through the project engineers; again, at times, this is less than desirable. For OSHP, the primary point of up-front contact and project review is through the Safety and Health Evaluation Support Team (SHEST). Since a SHEST team member has been assigned to each ORNL project engineer, communication of safety and health issues early in the project has improved significantly. 
Table C.1. Environment, safety, and health oversight survey responders who observed a wide diversity of oversight groups

\begin{tabular}{|c|c|c|c|c|c|c|c|c|c|c|}
\hline & \begin{tabular}{|c|} 
Contractors \\
$(13)$
\end{tabular} & Percent & \begin{tabular}{|c|} 
Customer \\
$(29)$
\end{tabular} & Percent & $\begin{array}{c}\text { ES\&H } \\
(7)\end{array}$ & Percent & $\begin{array}{l}\text { Project } \\
\text { eng } \\
(20) \\
\end{array}$ & Percent & $\begin{array}{c}\text { Total } \\
(69)\end{array}$ & Percent \\
\hline $\begin{array}{l}\text { Another construction } \\
\text { contractor's Safety Officer }\end{array}$ & 2 & 15 & & 0 & & 0 & & 0 & 2 & 3 \\
\hline $\begin{array}{l}\text { Construction contractor's } \\
\text { Safety Officer }\end{array}$ & & 0 & 18 & 62 & 3 & 43 & 13 & 65 & 34 & 49 \\
\hline $\begin{array}{l}\text { ATLC (Union) Safety } \\
\text { Representative }\end{array}$ & 0 & 0 & 6 & 21 & 1 & 14 & 3 & 15 & 10 & 14 \\
\hline $\begin{array}{l}\text { MK-Ferguson's ES\&H } \\
\text { Representative }\end{array}$ & 10 & 77 & 19 & 66 & 4 & 57 & 16 & 80 & 49 & 71 \\
\hline ORNL SHEST & 8 & 62 & 18 & 62 & 5 & 71 & 17 & 85 & 48 & 70 \\
\hline $\begin{array}{l}\text { ORNL division for whom } \\
\text { work was performed }\end{array}$ & 4 & 31 & 16 & 55 & 3 & 43 & 7 & 35 & 30 & 43 \\
\hline ORNL Safety Department & 7 & 54 & 9 & 31 & 2 & 29 & 5 & 25 & 23 & 33 \\
\hline $\begin{array}{l}\text { ORNL Radiological } \\
\text { Protection }\end{array}$ & 5 & 38 & 15 & 52 & 4 & 57 & 12 & 60 & 36 & 52 \\
\hline $\begin{array}{l}\text { ORNL Environmental } \\
\text { Compliance \& } \\
\text { Documentation }\end{array}$ & 6 & 46 & 9 & 31 & 0 & 0 & 7 & 35 & 22 & 32 \\
\hline $\begin{array}{l}\text { ORNL Eng. Electrical } \\
\text { Safety Eng. Group }\end{array}$ & 3 & 23 & 4 & 14 & 0 & 0 & 4 & 20 & 11 & 16 \\
\hline $\begin{array}{l}\text { ORNL Fire Protection } \\
\text { Engineering }\end{array}$ & 7 & 54 & 8 & 28 & 3 & 43 & 7 & 35 & 25 & 36 \\
\hline $\begin{array}{l}\text { Office of Operational } \\
\text { Readiness \& Facility Safety }\end{array}$ & 0 & 0 & 3 & 10 & 0 & 0 & 2 & 10 & 5 & 7 \\
\hline $\begin{array}{l}\text { LMES Safety \& Health } \\
\text { Representative }\end{array}$ & 8 & 62 & 4 & 14 & 0 & 0 & 0 & 0 & 12 & 17 \\
\hline $\begin{array}{l}\text { DOE-ORNL Site Office } \\
\text { Facility Representative }\end{array}$ & 2 & 15 & 6 & 21 & 1 & 14 & 4 & 20 & 13 & 19 \\
\hline $\begin{array}{l}\text { DOE-ORO ES\&H } \\
\text { Representative }\end{array}$ & 3 & 23 & 6 & 21 & 0 & 0 & 5 & 25 & 14 & 20 \\
\hline $\begin{array}{l}\text { DOE-HQ Safety } \\
\text { Representative }\end{array}$ & 1 & 8 & 3 & 10 & 0 & 0 & 4 & 20 & 8 & 12 \\
\hline $\begin{array}{l}\text { State of Tennessee ES\&H } \\
\text { Representative }\end{array}$ & 0 & 0 & 4 & 14 & 0 & 0 & 3 & 15 & 7 & 10 \\
\hline Other & 0 & 0 & 2 & 7 & 0 & 0 & 2 & 10 & 4 & 6 \\
\hline
\end{tabular}


The largest area of concern for these offices is the trend for more DOE-direct and EM-funded projects to be executed on-site at ORNL and the potential for their operating outside ORNL requirements. It is strongly recommended by all that any work ongoing on the ORNL site be performed according to ORNL ES\&H requirements. In particular, it is felt that construction subcontractor-provided ES\&H services are not presently adequate in meeting ORNL performance needs and that ES\&H involvement in construction-like subcontracting is very low in areas other than safety and health.

Oversight of performance is provided and funded by each of these offices, which is in addition to that contractually required and provided by the construction subcontractors. Provision of such oversight has a negative impact on ORNL overhead costs. Construction contractors should be required to perform to contract requirements and be held accountable in the ES\&H area.

The present SHEST team is performing as intended, but specific organizational guidance for involvement of ORP and OECD is needed to provide better overall coverage of compliance issues. It was suggested that the complex leaders were best equipped to be the key interface for ORP involvement in design and construction activities. It is also important for ORNL to provide a well-defined independent oversight function for construction ES\&H that is independent of the ongoing day-to-day ES\&H support functions presently provided by SHEST and the other offices.

Generally speaking, it was observed that ORNL project engineers are now accepting responsibilities for ES\&H in their projects but that additional training and knowledge related to these responsibilities would be recommended to improve overall performance.

Results-Recommendations were developed for a graded approach to risk evaluation, restructuring of the construction oversight function, and strengthened accountability of the construction contractors. These are given in the Recommendations section of this report.

\section{C.4.2.2 Relationship with the EM Program}

Issue-The number of EM projects on the ORNL site is increasing, and no ORNL project should be considered without taking EM plans into account. The possibility of a construction project being planned (unknowingly) near an EM project increases risks in all areas. The interface with EM has not been acceptably defined and executed in the past, but this should improve with the establishment of the ORNL Office of Environmental Management Programs.

Plan-A recommended action plan must be developed that Laboratory management can charter to implement in this area. A method of communication needs to be established between EM and ORNL to eliminate the adversarial situation that we now have. We may not want to admit that the adversarial situation exists, but it could even worsen when the Management and Integration contractor takes over the EM function on the Oak Ridge site. The establishment of more useful MOUs and MOAs should be considered.

The following questions were considered when examining this issue:

1. What are the near-term plans of the EM program that could impact ORNL operations? 
2. What method of communication between ORNL and EM would be the most effective?

3. What form should MOUs/MOAs take that would allow sufficient lead time as well as input from ORNL to be considered?

Results-ORNL has established the Office of Environmental Management Programs to deal with the issues and opportunities that develop between ORNL and the DOE-EM program. No further action by this team was pursued in this area.

\section{C.4.2.3 Relationships Within ORNL}

Issue-The divisions within ORNL do not consider the effect of their construction projects on others. In fact, the various divisions sometimes operate like independent, autonomous companies to a great extent. There is a distinct possibility that conflicting projects will be planned for the same areas of the Laboratory.

Plan-The following questions were considered when examining this issue:

1. How can communications between divisions be improved?

2. Can the ORNL ECMD be utilized to prevent conflicts in this area?

3. How can the Office of Planning and Management be utilized to keep divisions aware of overall Laboratory plans?

4. Can a reasonable Long Range Plan map of the Laboratory be developed to show these plans?

Results-ORNL's Office of Planning and Management should be utilized to minimize this risk. Since ECMD is involved in these projects, ORNL should examine the ways in which it might determine conflicts in the earliest stages of projects. (See Appendix C.5 for more details on this topic.)

\section{C.4.2.4 Design Risks}

Issue-The design stage is vital to the success of any project. The adequacy of the design, without the possibility of overdesign, must be considered during the planning and review stages of the project.

Plan-The issue of whether a mechanism is in place to ensure a well-thought-out Design Basis Document for each project was reviewed. This mechanism must include all the types of risks outlined here.

The following questions were considered when examining this issue and formulating survey questions.

1. Is the scope of the project correctly assessed?

2. Will the completed facility be adequate for the projected use?

3. Is the projected use adequately determined?

4. Is expansion in the future included in the plans for the project? 
5. Is the project properly designed for the risks that are to be handled by the facility upon completion?

6. Does the planned facility meet the needs of the user while addressing regulatory concerns (ES\&H, DOE orders, federal and state laws, etc.)?

7. Have the proper parties "bought into" the Design Basis Document?

Results-This area requires a more rigorous definition of the roles and responsibilities for ED\&C functions within ORNL and is covered in Section C.5. In addition, recommendations were developed for establishment of a more formal, graded approach to risk management at ORNL. This is given in the Recommendations section that follows.

\section{C.4.2.5 Legacy Risk}

Issue-ORNL was built during the height of World War II and was "expert driven" rather than "standards driven." The design and construction of the Laboratory, while very successful, did not take into account the possibility that ORNL would continue to exist many years after the conclusion of the war. As the Laboratory's mission changed, many new facilities were built, sometimes without adequate records of events and without adequate as-built drawings. The Laboratory staff continues to discover these "legacy" items when construction efforts are undertaken. Legacy items consist of everything from unknown contamination areas to underground pipes to areas within buildings that contain unknown hazards.

Plan-The following questions were considered when examining this issue:

1. Where are known areas of contamination at the ORNL site?

2. What areas other than radiation/contamination must be considered? Should asbestos, PCBs, chemical hazards, electrical, and other industrial hazards be considered?

3. Do maps exist of these areas? Has their information been converted to Map Info?

Results-The team found that existing maps are inadequate. There is no responsibility, authority, or funding to bring maps up to date, although this has been attempted sporadically in the past. This issue must be addressed in the ORNL overhead budget process.

ORNL should put a mechanism in place to allow a search of known data for such legacy problems. This risk is minimized by the use of green-field sites, but this is not always possible since it may be necessary to interface a new building with existing facilities. All new projects must be adequately documented with as-built drawings, and any discovery of legacy problems must be documented for possible future use. The use of the Map Info data base should be expanded in order to capture these items. 


\section{C.4.2.6 Site Management Risk}

Issue-Buildings are sometimes sited without adequate information regarding the plans for adjoining facilities. This is usually due to the fact that the various divisions have different sponsors and submit their requests for projects independently of each other. This has resulted in the second facility being sited in an inconvenient and sometimes expensive location, since the preferred location was already taken.

Plan-The questions that were considered when examining this issue and formulating survey questions are the same as those listed in Sect. C.4.2.4.

Results-The Capital Projects Group should address this early in the planning cycle. This area has been addressed in Sect. C.5.

\section{C.4.2.7 Capital Cost Versus Future Operational Cost Risk}

Issue-In order to maintain the cost of a project at a reasonable level, the future operational cost of the facility is sometimes ignored. The operator of the facility is then faced with the continuing problem of obtaining expense funds to operate what turns out to be an inefficient facility.

Plan-The following questions were considered when examining this issue and formulating survey questions.

1. How does ORNL ensure that operational areas are considered during the planning of capital projects?

2. How can ES\&H areas be included in Design Basis Documents in order to ensure that the cost of operating the facility from that standpoint is not excessive?

Results-The Design Basis Document is the key to avoiding this, and the operator of the facility must be involved in the development of this document. This area has been addressed in Sect. C.5.

\section{C.4.2.8 Fee Preservation Risk}

Issue-This risk should not be as prevalent as in the past since ORNL is now on a fixed-fee contract. In the past it was common to layer requirements (especially ES\&H requirements) in order to ensure that the contractor would not be subject to criticism, resulting in a reduced award fee. With some projects on the Laboratory site being conducted by LMES (still on the award or incentive fee), this problem remains.

Plan-The following questions were considered when examining this issue:

1. How will the ORNL Necessary and Sufficient (N\&S) set for construction and construction-like activities be implemented in construction projects?

2. How is the ORNL N\&S set to be implemented in EM projects on the ORNL site?

Results-The Laboratory must ensure compliance with ORNL N\&S standards for a given facility without being excessive. An ORNL-wide Reengineering Team is addressing the issues related to implementation of the "work smart" standards for construction and construction-like activities at ORNL. 


\section{C.4.2.9 High-Risk Contractor Risk}

Issue-Some contractors are excellent, but others can only be considered high risk. High-risk contractors require more surveillance, and their work is usually subject to retrofitting either prior to the end of the project or after the project has been turned over to the facility operator.

Plan-The following questions were considered when examining this issue and formulating survey questions.

1. How are contractors to be monitored while performing work at ORNL?

2. How does DOE monitor contractors, and how can this be improved?

3. How can contractors who perform poorly be prevented from obtaining future work at ORNL?

Results-DOE-ORO uses design and construction contracting to meet diversity goals, with the occasional result that inexperienced, high-risk contractors are selected. All the DOE energy research laboratories benchmarked by the Reengineering Team must meet DOE minority and small-business requirements, but none of the other energy research laboratories focus on design and construction to meet these goals. These laboratories use diversity contractors only where they have demonstrated competence. In fact, in benchmarking studies the Reengineering Team discovered that use of inexperienced contractors for work beyond their capabilities has had the unintended consequence of driving some contractors into bankruptcy. Adequate feedback to DOE regarding the performance of such contractors is essential to ensure that future work is assigned only to competent companies. Recommendations for selection and management of construction contractors were developed. They are contained in the Recommendations section that follows.

\section{C.4.3 Recommendations}

The ORNL ECMD has a Project Risk Evaluation Group, which uses a structured methodology to determine the probability of success of a project. This includes the probability of a project being completed on schedule and within budget and being able to perform its intended mission when complete. The use of this group should be more systematic with a graded approach in future activities, and a graded approach to risk evaluation should also be utilized. The comparison of an office building with a one-time R\&D project and the Spallation Neutron Source (SNS) is a good example of how a graded approach could be used. The political and technical risk is higher for the one-time R\&D project than for the office building, and the risk for the SNS is much higher still. Indeed, failure of the SNS could mean the end of ORNL. Consequently, we should not apply the rigor required for the SNS to the office building.

ORNL should assume immediate responsibility for ES\&H oversight of all work on the ORNL site with commensurate authority. ES\&H independent oversight of construction should be focused through a single overhead organization. This will eliminate the fragmented and often overlapping oversight activities that are currently in place under the direction of the ORNL Project Manager. The Project Manager should have primary oversight and be responsible for all aspects of an assigned construction project. All recommended ES\&H actions, except those involving imminent danger, should be resolved by the ORNL Project Manager. Ongoing support to the Project Manager, on a daily basis, should continue to be provided through a SHEST-like function, and oversight of construction must be provided via an independent function.

ORNL should award contracts only to highly qualified ED\&C firms that have demonstrated commitment to customer satisfaction, project performance, and ES\&H areas. These contractors should be held

$$
\text { C-102 }
$$


accountable for meeting applicable codes and standards, based on ORNL "work smart" standards for all activities on their work site.

A method is needed for ensuring accurate drawings of ORNL infrastructure facilities and for utilizing configuration management in a prioritized manner. It is recommended that the ORNL Infrastructure Program Manager assume this responsibility. Interviews/surveys indicate that ORNL atlas drawings as well as existing site drawings are not as-built at the conclusion of projects. A lack of a designated program or organization for providing these drawings was also indicated. It is recommended that the Office of Planning and Management and the ORNL ECMD be chartered to address this area. 


\section{C.5 ROLES AND RESPONSIBILITIES (S. E. Burnette and A. R. Medley)}

\section{C.5.1 Identification of Critical Issues}

Process mapping and identification of potential barriers to efficient ED\&C processes were conducted by the entire ED\&C Reengineering Team as an initial team effort. Subsequently, subteams were established to focus on specific areas for further investigation.

\section{C.5.2 Process}

The Roles and Responsibilities Subteam was assigned the following 19 potential barriers to investigate:

1. Lack of or poor up-front planning and communications

2. Multilayers of control-need to decide who is in charge

- Excessive ES\&H oversight increases cost

- ES\&H responsibilities are not well defined

3. No graded approach, associated with the amount and detail of project documentation required

4. Final project closeout and turnover-insufficient as-built drawings and documentation

5. Communication for collateral considerations

- Construction activity impacts customer operations

- Conflicting projects are planned for the same area

- Lack of coordination of construction exists with other impacted organizations

6. Graded approach to design

- Overspecification in design

7. Life-cycle analysis

- Capital cost versus future operating cost

- Considerations not always factored into design (may be due to limited capital funds available)

8. Lower-cost or less-complicated alternatives are not always considered in design

9. Too little continuity of project personnel from design through construction

10. Lack of project "postmortem" for "lessons learned"

11. Lack of Laboratory infrastructure configuration control

- Responsibilities not defined

- Funding not provided

12. Projects funded that are not the most important to ORNL mission

13. Length of project review and approval 
14. Late arrival of funding delays start of projects, resulting in discontinuity and associated increased cost

15. Vested interest in status quo-separation of LMER from LMES has not been fully implemented

16. Unwillingness to change

17. Inconsistency-need to standardize process

18. Project reporting is unreliable/inconsistent

19. Lack of communication

These potential barriers were subsequently grouped into four general areas of interest for further investigation:

1. project planning,

2. accomplishment of design,

3. ES\&H oversight, and

4. project closeout and turnover.

The Roles and Responsibilities Subteam utilized a number of sources to collect information related to the identified barriers. Survey questionnaires were sent to customers, contractors, ES\&H personnel, and project managers. Structured interviews were conducted with participants on the following seven major projects that are currently under construction or were recently completed:

- Sanitary Sewer System Upgrade Line Item

- Fire Protection Upgrade, 4500N Line Item

- Underground Storage Tank Project

- Solid State Research Facility Line Item

- Melton Valley-Low-Level Waste Collection and Transfer System Upgrade

- 3019 Glove Box Project

- T-2 Computer Lab Upgrade 
The following summarizes the project participants interviewed:

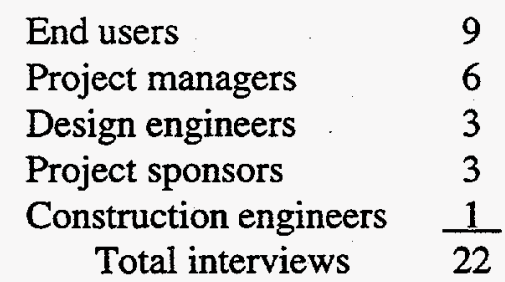

Attachment I (at the end of this appendix) is a copy of the interview form.

Video conferences were held with facility management personnel from five other DOE laboratories. Additionally, telephone surveys were conducted with six large general contractors in the Knoxville and Oak Ridge area.

The Roles and Responsibilities Subteam Leader also reviewed the Project Delivery System currently being implemented by the EMEF business unit and attended a 3-day training course on this system.

\section{C.5.3 Results}

\section{C.5.3.1 Project Planning}

Greater formality is needed in establishing roles, responsibilities, authority, and accountability for R\&D division directors, the Infrastructure Program manager, ORNL project managers, and other project participants. The success of a project, from development of the project scope and cost estimate through construction and startup, is dependent in great part on selection and chartering of the project team. Gaining the project team's commitment to achieving project goals and objectives is a critical element of chartering the team. Clearly established roles, responsibilities, and authority are essential for the efficient execution of project activities.

Organizations sponsoring projects must ensure that the scope of their needs are fully identified for the project team. They must also commit the time and resources necessary to support project team activities, especially in the areas of scope definition, design review, construction coordination, project acceptance, and startup. Sponsoring organization management must accept ownership and ultimate responsibility for the overall success of the project. Projects should be chartered by the most appropriate management organization, usually the cognizant R\&D division director or the Infrastructure Program Manager. The chartering organization is the primary "customer" of the project team.

Project managers must be vested with the authority to accomplish the project scope and then be held accountable for meeting project goals and objectives, within the budget and on schedule. Project team members must be accountable to the project manager for their participation in the project. For instance, ES\&H personnel assigned to such teams must understand that they are on the team to help identify project requirements, plan for provision of those requirements, and assist in surveillance of activities to ensure compliance with project plans. They are not there to act as "policemen." For projects that interface with existing facilities or infrastructure systems, the facility/system manager must be fully integrated with the project team to ensure adequate consideration of operational interfaces and collateral impacts to ongoing operations. In short, a fully integrated project team focused on project goals and objectives is essential to project success. 
Poor or inadequate up-front planning adversely affects cost, schedule, and customer satisfaction. All organizations affected by the project are not always involved in planning. End users who did not fully participate on the project team are more likely to be dissatisfied with project outcome. Contractors noted that "owners" should fully review design documents because most changes during construction are initiated by them. Some customers may need help in interpreting design documents and encouragement to take time to review the design. Projects in which all participants were identified at the outset and provided time to discharge their project duties are more likely to be perceived as a success.

ORNL should integrate the processes for planning and justifying infrastructure projects and ORNL programmatic strategic planning. A consistent approach for planning, prioritization, and tracking of highpriority infrastructure needs is required. Currently, the Infrastructure Management Information System (IMIS) contains data on identified infrastructure needs and proposed programmatic projects. The Capital Assets Management Program (CAMP) prioritization matrix is used to prioritize all projects in IMIS. Programmatic sponsors do not proactively submit information on proposed projects to the Infrastructure Program Manager for inclusion in IMIS. Comprehensive information concerning infrastructure and programmatic requirements is needed to ensure that limited infrastructure program resources are used in a manner consistent with priorities of present and emerging ORNL programmatic requirements.

The primary sources of data concerning project management issues were the structured interviews with project participants. Project managers and customers had differing perceptions as to the involvement of customers in project-planning activities. Project managers generally felt that customers were highly involved in such activities. The customers, in general, felt they were only "somewhat" involved in project planning. Several customers also indicated that their participation was constrained by other responsibilities and job commitments and the fact that their participation in project activities was not funded in the project budget.

With respect to the site process for prioritizing infrastructure requirements, $100 \%$ of end users, program sponsors, and project managers interviewed for recently completed ORNL ED\&C projects stated that they were not involved in the ORNL infrastructure prioritization process for selecting needed upgrade projects. Fifty percent of the project managers, $67 \%$ of the project sponsors, and $100 \%$ of the end users were not even aware that a prioritization process exists.

A general concern, expressed by many project participants, was the negative impact of changes in key project personnel. Some projects experienced two, three, or even four changes in project management over the course of the project. Lack of continuity in project team participants resulted in inefficiencies, lack of focus, and poor communication. Reassignment of project responsibilities between team members and participating organizations should be minimized.

\section{C.5.3.2 Accomplishment of Design}

The lack of a role for the end user in the design process results in customer (end-user) dissatisfaction with the design product. Customers feel isolated from the design activities. They perceive they have little or no input into who does the design. They also feel that their comments on design documents are not uniformly considered. Since DOE holds the A/E contracts, there is a problem in defining who the customer is-DOE, the project manager, or the end user. There is the perception, especially on line-item projects, that $\mathrm{A} / \mathrm{E}$ firms are concerned only with pleasing $\mathrm{DOE}$, not the project team or the end user.

There is also a concern that a graded approach need to be applied to the level of detailed design required for smaller, less complex projects. 
Results show that $40 \%$ of the customers surveyed believed that insufficient review of potential design risk was conducted with the operating staff. The customers $(42 \%)$ felt that insufficient consideration was given to the cost of operating the completed project. Many customers (66.7\%) indicated they were not involved in the selection of the design organization. Fifty-four percent of customers indicated that they were satisfied with the extent of their involvement in the design process.

Both customers (39.1\%) and project managers (35\%) were about equally dissatisfied with the work performed by the design organizations. The structured interviews indicate that customers from service organizations, such as Plant and Equipment Division (utility operations) and Fire Protection Engineering, tended to perceive that they were more involved in design activities than did the R\&D organization customers. Additionally, value engineering was generally recognized to be beneficial to the design effort for those projects where it had been applied.

\section{C.5.3.3 Environmental Safety and Health Implementation and Independent Oversight}

The project manager should be responsible for all aspects of an assigned construction project. All recommended ES\&H actions, except those involving imminent danger, should be resolved by the ORNL project manager. ES\&H staff assigned to a project team for planning and surveillance should report to the project manager. Independent ES\&H oversight of project activities should be coordinated through one independent organization.

General consensus among project managers $(47 \%)$, customers $(52 \%)$, and contractors $(100 \%)$ is that excessive ES\&H oversight exists for most projects. These groups also perceive that a direct cost impact results from excessive ES\&H oversight. However, ES\&H personnel (71\%) indicated that ES\&H planning and oversight are inadequate. Customers (58\%), project managers (72\%), ES\&H respondents (70\%), and contractors (70\%) responded that the ES\&H oversight did not add value to projects. Contractor survey responses indicate that they perceive oversight by at least five ORNL, one LMES, and one MK-Ferguson organization exists. They also indicate that inconsistent interpretation and application exist regarding ES\&H requirements. Over the past year, some improvement have been observed in ES\&H oversight, ascribed primarily to more effective interface with the SHEST process. Many organizations provide ES\&H oversight in a duplicative uncoordinated manner. The following lists survey results for ES\&H oversight observations of construction projects from the 69 survey respondents:

\section{ORNL Overhead}

Safety and Health Evaluation and Support Team (SHEST)

Radiological Protection

Fïre Protection Engineering

Safety Department

Environmental Compliance and Documentation

Operational Readiness and Facility Safety

Observations
48
36
25
23
22
5

Other

MK-Ferguson ES\&H

ORNL Division

LMES Safety and Health

12

Engineer Electrical Safety

11

ATLC Safety 


\section{C.5.3.4 Project Closeout and Turnover}

"As-built" drawings and facility/equipment documentation are not provided to facility managers at the end of projects. Configuration management and control are difficult to maintain without this documentation. Project drawings are frequently "redlined" during construction. However, they generally are not revised at the end of the project to reflect as-built conditions. Furthermore, related utility/facility drawings are not revised to reflect the as-built conditions. Equipment operating and maintenance instructions frequently do not end up with the facility operating organization.

End users, project managers, and project sponsors interviewed for recently completed ORNL ED\&C projects agreed that the project drawings are generally either as-built or redlined after the project is completed; however, $100 \%$ of each group stated that the ORNL atlas and existing site drawings were not as-built after their project was completed.

Seventy-eight percent of the project managers and design engineers interviewed for recently completed ORNL projects stated that there is not an organization funded or responsible for providing as-built ORNL site drawings.

\section{C.5.4 Conclusions and Recommendations}

\section{C.5.4.1 Project Planning}

\section{Conclusion}

A focused project team effort encompassing all affected organizations is needed to ensure adequate project planning. Team members must be committed to project objectives and goals.

\section{Recommendations}

- Project teams should include representatives from all affected organizations. Each project participant, including the end-user organizations, should be provided the time and support necessary to effectively execute project requirements.

- The project team should jointly develop the detailed project scope, responsibilities, and division of work, including collateral impacts to ongoing operations, in order to gain consensus and commitment to project objectives and goals. (Affinity diagram process is a good technique for this.)

- The project team should be formally chartered by Laboratory management with clear project objectives, goals, and team member responsibilities. The team should be chartered by the most appropriate management organization. $R \& D$ division directors and the Infrastructure Program Manager should be responsible and accountable for programmatic- and Landlord-funded ED\&C projects, respectively.

- The project team should stay intact during the course of the project.

- Value engineering should be applied to project design and planning.

- A consistent, integrated approach for planning, prioritizing, and tracking of high-priority infrastructure needs should be implemented. 


\section{C.5.4.2 Accomplishment of Design}

\section{Conclusion}

End users perceive that their needs are not adequately addressed in the design process.

\section{Recommendations}

- The end user should be involved in determining the method of accomplishment for design activities and selection of design agencies.

- LMER should hold design contracts.

- The end-user organization must devote the necessary time and resources to adequately support project design activities.

- A graded approach should be applied to design requirements for projects based on size and complexity.

- National codes and standards should be referenced, whenever practical, in design documents.

\section{C.5.4.3 Environmental, Safety, and Health Oversight}

\section{Conclusion}

Multilayered ES\&H oversight is perceived as excessive. Consistent interpretation of ES\&H requirements is not always applied during this course of a project. Project managers have limited control over the ES\&H oversight imposed on their projects.

\section{Recommendations}

- The project manager should be given authority and accountability for project ES\&H compliance.

- Independent ES\&H oversight during project planning and execution should be provided by only one ORNL organization. If an independent ES\&H oversight person does not concur with the ORNL project manager's resolution, this individual can pursue the issue through his/her line organization.

- ES\&H participants assigned to the project team should be fully integrated with the project team and under the direction of the project manager.

- Contractor safety programs should be evaluated utilizing a standard measure, such as the Experience Modification Rate (EMR) prior to awarding a contract.

- ORNL should implement the approved Necessary and Sufficient standards for construction and construction-like work.

\section{C.5.4.4 Project Closeout and Turnover}

\section{Conclusion}

A concentrated effort should be made to ensure as-built drawings and equipment data/operating and maintenance instructions are provided to the facility operator at the end of a project. 


\section{Recommendations}

- Project plans should specify requirements for as-built drawings, on a graded-approach basis, as needed for the project.

- A procedure should be established to ensure that as-built drawings and equipment data/operating instructions are delivered to the end user at the completion of a project.

- Project cost estimates should provide for as-built drawing and equipment data turnover at the end of the project.

- Site infrastructure drawings, such as atlas drawings, should be assessed to determine the need for updating them to as-built drawing status. 


\section{R \& R SUB-TEAM STRUCTURED INTERVIEW BLANK}

Instuctions to Participants (to be read aloud by interviewer):

This interview is intended to gather information about topics related to design and construction projects at ORNL. I will read you a series of questions: for some of the questions I will ask you to provide a rating. After giving me the rating. I will ask for any comments you care to make. Some questions will not ask for a rating. but will instead ask for your opinion on design and consuruction-related management processes. Please answer the questions in terms of the project.

Your identity in this study will be treated as confidential. The results of the study. may be published for ORNL Re-engineering purposes but will not give your name or include any identifiable references to you.

Please provide an overall general description of the project.

What was the project size (in dollars)? $<\$ 100 \mathrm{~K}$

$\$ 100 \mathrm{~K}$ to $\$ 350 \mathrm{~K} \quad \$ 350 \mathrm{~K}$ to $\$ 2 \mathrm{M}$

$>2 \mathrm{M}$

$\square$

$\square$

$\square$

1. How was the organizational hierarchy estabiished for the project?

3. Who was responsible for:

- Project Management

- Design

- ES\&H Over-site

- Construction

- Procurement

Page 1 of 8 
Attachment I

b. Was the design authoriry ciearly defined?

- Rating: Very Cleariy Defined

Clearly Defined

Very Poorly Defined

- Comments:

2. To what extent was the end user involved in:

Highly involved

Somewhat Involved

Not Involved

Don't Know

a) Project scope definition

口

口

口

口

$\square$

๘

b) Project requurements

ㅁ

$\square$

口

口 specification

c) Conceprual design review

a

$\square$

a

ㅁ

0

d) Detailed design review

0

a

口

ㅁ

$\square$

$\square$

口

e) Project Planning

ㅁ

口

○

a

$\square$

f Construction over-site

a

口

ㅁ

口

व

g) Walk down for punch list

口

口

ㅁ

c

$\square$

a

3. What role did the end user play in the establishment of the project team?

Page 2 of 8 
\& Please indicate your level of agreement with the following statements?

\begin{tabular}{|c|c|c|c|c|c|}
\hline $\begin{array}{l}\text { Strongly } \\
\text { Agree }\end{array}$ & & Agree & & $\begin{array}{l}\text { Strongly } \\
\text { Disagree }\end{array}$ & $\begin{array}{l}\text { Don': } \\
\text { Know }\end{array}$ \\
\hline 口 & 0 & 口 & D & ם & $\square$ \\
\hline$a$ & $\square$ & $\square$ & $=$ & D & ב \\
\hline 口 & 口 & $\square$ & a & 口 & 口 \\
\hline 口 & D & $\square$ & c & घ & ב \\
\hline
\end{tabular}

5. What roles did the facility manager or their representative play on the project team?

6. How did the project team manage interfaces with ongoing operations?

Page 3 of 8 
- What project documentation was required?

a (CDR) Conceptual Design Report

c (SRD) Systems Requirements Doc.

口 Design Criteria

- Drawing \& Specifications

口 QA Plan

- Waste Management Plan

ㅁ Safery Assessment

C Status Reports

a Project Change Order

a. Did all of the project documents prepared add value to the project? If not. what could be eliminated?

8. Were design documents:

$\begin{array}{ccccc}\text { Overiy } & & \text { Appropriately } & & \text { Under } \\ \text { Specified } & & \text { Specified } & & \text { Specified } \\ \square & \square & \square & \square & \square\end{array}$

a. Comments:

9. Did the designers look for alternative designs to meet project requirements?

a. Were these alternatives shared with the end users? 
10. The level of ES\&H over-site was:
Insufficien:
a.
Just Right
Overkili
c
$\square$
○
[

If not appropnate. what recommendations would you make for improvement

11. The documentation provided to the end-user was:
insufficient
Just Right
Overkill
c
D
口
$\square$
a

12. The as-built drawings provided to the organization responsible for operational configuration control were:
Insufficient
Just Right
Overkill
口

$\square$
口
口
口

If not appropriate. what recommendations would you make for improvement?

13. Was a project review completed at the end of the project to identify lessons learned? If so. who were the individuals and organizations involved in this process, and were these the appropriate individuals?

Page 5 of 8 
14. In relatton to the project team and project management. what worked well. what didn it work. and what would you do differentiy if you had to do it over again?

15. In relation to the design process. what worked well. what didn't work. and what would you do differently if you had to do it over again?

Page 6 of 8 
16. In reiation to the construetion process. what worked well. what didn t work. and what would you do differently if you had to do it over again?

17. In relation to the ES\&H over-site for the construction, what worked well. what didn it work. and what would you do differently if you had to do it over again?

Page 7 of 8

C-118 
18. In retation to the project closeout and turnover to the end user. what worked well. what didn' 8 work. and what would you do differently if you had to do it over gain?

19. Does the Laboratory infrastructure prioritization process for selecting projects adequately reflect the needs of the laboratory?

a. If not. how should the prioritization process be improved?

Page 8 of 8

C-119 


\section{C.6 LMER CONTRACTING AUTHORITY AND EXPERIENCE (J. T. Etheridge)}

\section{C.6.1 Introduction}

This subteam collected information related to barriers to an efficient ED\&C process at ORNL:

1. LMER authority to contract directly for engineering design services with $A / E$ firms.

2. Cost drivers that result in higher costs for ED\&C work at ORNL than would be the case in the commercial sector.

\section{C.6.2 Process}

Information was developed by the subteam via three approaches:

1. Review of the LMER contract, applicable parts of the Federal Acquisition Regulations (FAR) and the DOE Acquisition Regulations (DEAR).

2. Discussions with representatives of the DOE-Oak Ridge Engineering Organization about factors that determine past, present, and potential approaches to contracting for A/E services.

3. Phone interviews with selected local A/E firms to determine important differences between government and commercial work, to identify cost drivers that result in higher costs for government work, and to obtain suggestions for improvements in the ORNL engineering design process.

\section{C.6.3 Results}

Contracting for ED\&C services plays a major role in providing ED\&C support to ORNL. Currently, engineering design services are provided through $\mathrm{DOE}$ prime contracts to various $\mathrm{A} / \mathrm{E}$ firms. Any work performed by these $\mathrm{A} / \mathrm{E}$ firms goes through the designated DOE Engineering Project Manager, who serves as the Contracting Officer's Technical Representative (COTR). DOE has maintained prime engineering contracts for years as a basis of controlling the overall design of facilities across the Oak Ridge Reservation. The need to maintain this consistency lessens as the missions of the various sites become less focused.

DOE has controlled construction in the past through prime contracts. Most recently, DOE utilized the services of a general construction manager to manage all the construction activities at DOE-ORO sites. This prime contract was viewed as a means of increasing efficiency over a large volume of construction work. In recent years, however, the volume of construction has decreased considerably to the point where the gains in efficiency of the general construction manager are not being realized. The volume of construction at ORNL currently does not warrant a general construction management-type contract. At the time of this study, construction management services were being provided through a memorandum of understanding (MOU) between LMES and LMER. MK-Ferguson of Oak Ridge is the construction manager under contract with LMES. The MOU between LMER and LMES stated that LMER will acquire construction management services from LMES during FY 1997. The MOU further states that during FY 1997 LMER would establish a plan to acquire future construction services. 


\section{C.6.3.1 LMER Contracting Authority}

LMER has contracting authority under its contract (DE-AC05-96OR22464) with DOE for materials, supplies, and services, including ED\&C services. The LMER contract cites requirements for LMER to use certain clauses from the FAR in subcontracts awarded by LMER. The contract does not, however, require LMER to follow the FAR procedures in exercising its contracting authority.

\section{C.6.3.1.1 Construction Contracting Authority}

Requirements for providing construction can be found under Sect. C of the contract (Descriptions/ Specifications/Work Statement), C.1 [Statement of Work (Oct 1995)], (b) (Description of Work and Activities), Part III-Services, paragraph (iii):

Construction services shall be provided for all programs and activities described in the Statement of Work. This includes construction of line item projects, general plant projects, operations funded projects, other capital projects including the acquisition of basic capital equipment in support of ORNL missions and associated support activities, other projects in support of all missions, and other projects as DOE and the Contractor shall agree in writing.

The mention of construction-related activities is included in various other clauses in the contract. These references refer primarily to subcontracting activities rather than providing construction support using LMER employees and are included in the following clauses:

I.13 FAR 52.219-9, Small Business and Small Disadvantaged Business Subcontracting Plan (Feb 1995), subparagraph $(d)(q)$, requires subcontracting plans and requirements to include the clause entitled "Utilization of small business concerns and small disadvantaged business concerns." This clause is required in all contracts greater than $\$ 1,000,000$ for construction.

I.41 FAR 52.225-15, Buy American Act-Construction Materials Under European Community and North American Free Trade Agreements (Jan 1994), deals with the requirements for buying construction materials from specific areas.

I.67 DEAR 952.250-70, Nuclear Hazards Indemnity Agreement (Jan 1992), paragraph (e)(2)(I), mentions construction as an activity under which an extraordinary nuclear occurrence takes place.

1.74 DEAR 970.5204-13, Allowable Costs and Fee (Management and Operating Contracts) (Sept 1991) (Deviation), paragraph (c)(17)\&(18), mentions construction plant and equipment maintenance, inspection, repair, replacement, and transportation as allowable cost. Under paragraph (e)(28), special construction industry funds are listed as unallowable cost.

I.92 DEAR 970.5204-38, Government Facility Subcontract Approval (Apr 1984), reads as follows:

Except as approved by the Contracting Officer, the Contractor shall procure, by subcontract the construction of new facilities or the alteration or repair of Government-owned facilities at the plant. Any subcontract entered into under this paragraph shall be subject to the written approval of the Contracting Officer and shall contain the provisions relative to labor and wages required by law to be included in contracts for the construction, alteration, and/or repair, including painting and decorating, of a public building or public work. 
This contract clause is required for inclusion as directed by DEAR clause $970.5204-3$ where Maintenance \& Operation's internal staff are not to be used to perform construction activities.

\section{I.103 FAR 52.227-1, Authorization and Consent (Apr 1984), paragraph (b), reads as follows:}

The Contractor agrees to include, and require inclusion of, the clause, at 48 CFR 52.227-1 suitably modified to identify the parties, in all subcontracts at any tier for supplies or services (including construction, architect-engineer services, and materials, supplies, models, samples, and design or testing services) expected to exceed $\$ 25,000$; however, omission of this clause from any subcontract, under or over $\$ 25,000$, does not affect this authorization and consent.

As mentioned earlier, the LMER contract prohibits the use of LMER employees for doing construction by the inclusion of clause I.92 DEAR 970.5204-38, Government Facility Subcontract Approval (Apr 1984). In the same vein, the FAR requires certain clauses to be inserted if construction is to be included in the contract. These clauses are as follows:

FAR 522.222-6, Davis-Bacon Act

FAR 522.222-7 Withholding of Funds

FAR 522.222-8, Payrolls and Basic Records

FAR 522.222-9, Apprentices and Trainees

FAR 522.222-10, Compliance with Copeland Act Requirements

FAR 522.222-11, Subcontracts (Labor Standards)

FAR 522.222-12, Contract Termination-Debarment

FAR 522.222-13, Compliance with Davis-Bacon and Related Act Regulations

FAR 522.222-14, Disputes Concerning Labor Standards

FAR 522.222-15, Certification of Eligibility

All of these clauses are included in the LMER contract with the exception of FAR 522.222-9, Apprentices and Trainees. For LMER to be able to perform construction activities with LMER employees, the clause at FAR 522.222-9 would have to be included and the clause I.92 DEAR 970.5204-38, Government Facility Subcontract Approval (Apr 1984), would have to be removed from the LMER contract. This would require a bilateral contract modification.

\section{C.6.3.1.2 Engineering Services Contracting}

Contracting for engineering services, including A/E-type design contracts, is included in the LMER contract under Sect. C (Descriptions/Specifications/Work Statement), C.1 [Statement of Work (Oct 1995)], (b) (Description of Work and Activities), Part III-Services, paragraph (iv), and reads as follows:

Engineering services shall be provided to support the programmatic missions of ORNL. This includes engineering services for operations, maintenance, construction, decommissioning, and demolition of facilities.

LMER currently subcontracts engineering support services but not A/E-type design services. As stated earlier, DOE-Oak Ridge has traditionally accomplished this directly. The LMES contract does not permit this type of contracting. Discussions with Dennis Boggs of DOE-Oak Ridge Engineering revealed several aspects of DOE's past approach to $\mathrm{A} / \mathrm{E}$ contracting. The use of prime $\mathrm{A} / \mathrm{E}$ contracts was to control scope and cost and to provide consistency and uniformity across the Oak Ridge Operations sites. 
The prime contractors served as a check and balance against the $\mathrm{M} \& \mathrm{O}$ prime engineering organizations and vice versa. DOE uses the policy and procedures outlined in the Brooks Bill. (As stated in the Brooks Bill policy, "The Congress hereby declares it to be the policy of the Federal Government to publicly announce all requirements for architectural and engineering services, and to negotiate contracts for architectural and engineering services on the basis of demonstrated competence and qualification for the type of professional services required and at fair and reasonable prices.") Mr. Boggs sees the future of $\mathrm{A} / \mathrm{E}$ contracting as being the responsibility of the DOE-Oak Ridge prime $\mathrm{M} \& \mathrm{O}$ and $\mathrm{M} \& \mathrm{I}$ contractors. DOE-Oak Ridge has recently approved conceptual design reports that show the M\&O managing the design process through awarding an $A / E$ contract. It is anticipated that $L M E R$ will manage most future A/E design activities.

Although the Brooks Bill policy and procedures have been used for years to acquire A/E design services, the FAR Part 12 (Acquisition of Commercial Items) is being used by some DOE sites as the basis for engineering services. This guidance allows commercial means and methods of contracting for services. These methods will be evaluated as possible means for negotiating and awarding $A / E$ service contracts by LMER.

\section{C.6.3.2 A/E Contractor Interviews}

In reviewing the contract aspect of construction and engineering services, phone interviews were conducted with five local A/E firms, which have routinely performed work for DOE and DOE M\&O contractors. These firms also perform a considerable amount of work for commercial clients. The firms interviewed were

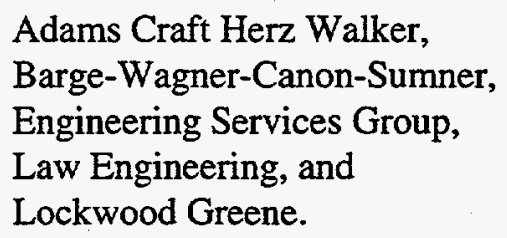

Each of the firms was asked a series of questions, in an effort to determine the differences between government and commercial work, to identify cost drivers on government work, and to gather suggestions for improvements in the engineering design process.

Government contracts were described as being too complicated and the contract language too specific. A standard government contract ranges between $1 / 2$ to 2 in. thick. A standard commercial contract runs approximately 15 pages with language that is used throughout the industry. A common format used is the American Institute of Architects (AIA) contract. This format is simple, easily understood, and clearly lays out the requirements for the $\mathrm{A} / \mathrm{E}$. Most commercial $\mathrm{A} / \mathrm{E}$ contracts start with a handshake between an owner/operator and the $\mathrm{A} / \mathrm{E}$ firm. Most $\mathrm{A} / \mathrm{Es}$ experience long-term relationships with their clients. Commercial clients are more reliant on the $\mathrm{AVE}$ for their expertise. Commercial work allows more flexibility in the development of the scope of the work, thus allowing the client and the A/E to jointly develop solutions. Government scopes of work are better developed but are more costly. Most A/Es felt that government clients are not aware of cost drivers or as concerned about the costs associated with multiple reviews, excessive oversight, or multiple submittal requirements. The requirements for excessive design documents, reports, calculation records, and final deliverables further emphasized this fact. The final difference discussed was the contracting methods used. Commercial work uses more flexible contracting methods, such as cost plus or hourly rate, during scope definition and then a fixed price for final design. 
In discussions on cost drivers, all the firms felt government work was more costly. This was attributed to a number of factors. Government work lacks a tailored approach. No matter what the size of the design effort, the same amount of paperwork and review is used. Design reviews were a major cost factor. Most were accomplished in an unorganized fashion and lasted too long. The extended reviews have a negative impact on the A/E's staffing/work load planning. During extensive review periods, the $A / E$ has to find other work for the design staff. This creates problems with continuity of job assignments and client relations. Government work requires excessive training and safety concerns. A lot of the training is invoked due to the "one-size-fits-all" mentality. Adherence to DOE orders extends the cost of providing services. Often the DOE orders are applied in a blanket fashion. A major concern of several firms is government project managers lacking the authority to make decisions. This creates delays and greatly slows design progress by making comment resolution difficult. In most cases, the AVE project manager ends up making decisions that should be made by the government project manager. Many design packages are poorly arranged and duplicated. This causes errors and miscommunication. Excessive oversight by government design groups increases cost to both the $\mathrm{A} / \mathrm{E}$ and the government. The design standards for most government projects differ from commercial work. The learning curve on these standards drives cost.

The firms had several suggestions for improvement. Regional building codes should be used for design contracts and construction. These are the standards the $A / E$ is most familiar with, and using them will also decrease the construction bids for work. Contracts should be simplified both in format and requirements. Utilization of the AIA format would decrease design cost. The M\&Os should conduct their own contracting for engineering design services. The current DOE prime contract approach requires the $\mathrm{A} / \mathrm{E}$ to go through several different channels to finally reach the $\mathrm{M} \& \mathrm{O}$ project or design representatives. This approach of using DOE prime contracts for $\mathrm{A} / \mathrm{E}$ services is unique with $\mathrm{DOE}-\mathrm{ORO}$. Building design teams from the $\mathrm{A} / \mathrm{E}$ and the $\mathrm{M} \& \mathrm{O}$ 's design disciplines would greatly improve the communications aspects of design. This single action would improve cost and timeliness of designs. By working daily side by side, the $\mathrm{A} / \mathrm{E}$ and $\mathrm{M} \& \mathrm{O}$ could improve design efficiency. If at all possible, work should be fenced off to reduce sidewalk oversight. Design requirements should be tailored to match the needs of the project.

\section{C.6.4 Conclusions}

The current ORNL contract (DE-AC05-96OR22464) stipulates LMER is to provide construction services for all programs and activities described in the Statement of Work, including construction of line items, general plant projects, operations-funded projects, and other capital projects. Engineering services are to be provided for activities at ORNL, including construction and maintenance activities. Physical construction by LMER employees is not authorized under the contract. The construction, alteration, or repair of government facilities is to be subcontracted.

DOE is looking for LMER to carry out its construction and engineering services mission in a costeffective manner that adheres to applicable laws, requirements, and industry standards.

\section{C.6.5 Recommendations}

LMER should proceed with the development of procedures, policies, and practices to contract directly for $\mathrm{A} E$ E services and construction. Various methods of accomplishment need to be developed that allow more flexibility in meeting the requirements of projects and ongoing operations. LMER should use existing staff for managing design and construction functions. 


\section{C.7 FUNDING CONSIDERATIONS (S. D. Frey)}

\section{C.7.1 Introduction}

This subteam obtained information relative to several potential barriers to efficient ED\&C process at ORNL that relate to the following areas:

1. categories of funding,

2. alternate funding methods,

3. unfavorable funding profiles, and

4. program/infrastructure decisions on use of funding.

The current levels of funding are inadequate to remediate identified ORNL infrastructure and facilities needs in a responsible way. A number of causes in combination have resulted in this situation and, if remedied, a significant improvement in the condition of ORNL facilities could occur over time. The largest gains are probably possible in more efficient use of funds through streamlined processes in implementing ED\&C activities. Solutions to these problems are considered in other subteam sections. The following issues more directly relating to funding or obtaining funding are addressed here:

- Different types of projects are funded through different types of funds. In general, this restricts flexibility in dealing with capital issues and forces projects to be sized and implemented based on availability of a particular category of funds, rather than on mission need.

- There are numerous projects and infrastructure issues for which a funding source has not been identified. Unfunded infrastructure and facilities issues include orphan facilities, ES\&H deficiencies, Reservation infrastructure issues, and energy-savings opportunities. To support this, alternate methods for funding critical infrastructure issues need to be identified.

- Funds that arrive late in the funding year delay the start of projects and result in poor costing performance or increased cost. In addition, work on projects that are phase funded must be scheduled based on the availability of funds, rather than on optimal project planning.

- When a decision between competing interests (program activities, ES\&H, infrastructure upgrade and repair, etc.) is made, infrastructure and facilities issues often assume a low priority.

\section{C.7.2 Process}

Information was developed by the subteam via discussion with selected individuals in the budget and finance areas of DOE-Oak Ridge and DOE-HQ and by review of related Congressional, Office of Management and Budget (OMB), and DOE guidance documents.

\section{C.7.3 Categories of Funding}

ORNL funding can be divided into operating expense and capital funding. The DOE Accounting Handbook referenced to General Accounting Office (GAO) standards defines what must be capitalized and what can be regarded as operating expense. It defines categories of capital work-such as GPPs, line items, and GPEs-as well as categories of operating expense such as overhead, alteration, repair, and maintenance. Expressed limitations in the use of these categories of funds make funding projects somewhat complicated and reduce the efficiency of fund usage. 
The Congressional, OMB, and DOE-HQ budget guidance further defines what can be funded within certain categories of funds and gives guidance on budgeting and usage. HQ guidance includes both DOE policy and OMB circular A-11 ("Preparation and Submittal of Budget Estimates") guidance. Normally, projects that result in a capitalizable product must use capital funds.

\section{C.7.3.1 Results}

The following paragraphs briefly describe the basic types of available infrastructure and facilities funding within the operating expense and capital categories. The limitations on the use of each is described, and areas of possible flexibility are noted. Refer also to Table C.2 for a summary of this information.

Table C.2. Categories of funds

\begin{tabular}{|c|c|c|c|c|}
\hline Category & Description & Limitations & Example & References \\
\hline $\begin{array}{l}\text { Operating } \\
\text { (program) }\end{array}$ & $\begin{array}{l}\text { Funds provided for } \\
\text { specific program } \\
\text { activities }\end{array}$ & $\begin{array}{l}\text { Must be used for specified } \\
\text { program activity } \\
\text { (Can be converted to GPP/GPE } \\
\text { if Landlord program) }\end{array}$ & $\begin{array}{l}\text { Basic Energy } \\
\text { Sciences Program } \\
\text { Biology Program }\end{array}$ & $\begin{array}{l}31 \text { USC } 1514 ? ? \\
\text { OMB A-34 } \\
\text { Congressional } \\
\text { appropriation language }\end{array}$ \\
\hline $\begin{array}{l}\text { Operating } \\
\text { (overhead) }\end{array}$ & $\begin{array}{l}\text { Cost incurred for general } \\
\text { management, } \\
\text { administration, and } \\
\text { operating of the } \\
\text { contractor and other costs } \\
\text { not directly associated } \\
\text { with specific efforts }\end{array}$ & $\begin{array}{l}\text { Overhead can be used only for } \\
\text { small construction activities } \\
\text { that do not meet the } \\
\text { capitalization criteria (property } \\
\text { unit catalog definitions) } \\
\text { Cannot be used to purchase } \\
\text { capital equipment valued at } \\
\$ 25 \mathrm{~K} \text { or more }\end{array}$ & $\begin{array}{l}\text { Repaving } \\
\text { Roofing } \\
\text { Maintenance }\end{array}$ & $\begin{array}{l}\text { FY99 HQ Field Budget } \\
\text { Call } \\
\text { DOE Acct Handbook } \\
\text { GAO Acct Standards }\end{array}$ \\
\hline Capital equipment & $\begin{array}{l}\text { Funds provided for } \\
\text { program or general- } \\
\text { purpose capital equipment } \\
\text { items costing more than } \\
\$ 25 \mathrm{~K}\end{array}$ & $\begin{array}{l}\text { Cannot include more than } 20 \% \\
\text { construction }\end{array}$ & $\begin{array}{l}\text { Chiller replacement } \\
\text { Vehicles over } \$ 25 \mathrm{~K}\end{array}$ & $\begin{array}{l}\text { Congressional } \\
\text { appropriation language } \\
\text { DOE Acct Handbook }\end{array}$ \\
\hline $\begin{array}{l}\text { GPP/Accelerator } \\
\text { Improvement Projects }\end{array}$ & $\begin{array}{l}\text { Minor new construction } \\
\text { projects of a general } \\
\text { nature, the total estimated } \\
\text { cost of which does not } \\
\text { exceed the Congressional } \\
\text { authorization of } \$ 2 \mathrm{M} \text { per } \\
\text { project }\end{array}$ & $\begin{array}{l}\text { 1. TEC for each project needs } \\
\text { to stay within } \$ 2 \mathrm{M} \text { limit } \\
\text { 2. Cannot do operating or } \\
\text { maintenance-type activities } \\
\text { 3. Cannot incrementally build } \\
\text { larger upgrade or facility } \\
\text { using multiple GPPS } \\
\text { 4. Cannot split-fund }\end{array}$ & $\begin{array}{l}\text { Generic office } \\
\text { buildings } \\
4510 \text { Cooling Tower } \\
3019 \text { ventilation } \\
\text { improvements } \\
\text { (Defense Programs) }\end{array}$ & $\begin{array}{l}\text { Congressional } \\
\text { appropriation language } \\
\text { DOE M 135.1-1 Budget } \\
\text { Execution Manual } \\
\text { FY99 HQ Field Budget } \\
\text { Call }\end{array}$ \\
\hline Line-item construction & $\begin{array}{l}\text { Funds that are } \\
\text { appropriated by Congress } \\
\text { for a specific general- } \\
\text { purpose or program } \\
\text { construction activity and } \\
\text { have a TEC of } \$ 2 \mathrm{M} \text { or } \\
\text { more }\end{array}$ & $\begin{array}{l}\text { 1. Need to go back to } \\
\text { Congress if additional funds } \\
\text { are needed } \\
\text { 2. Must do scope specified in } \\
\text { Congressional data sheet }\end{array}$ & $\begin{array}{l}\text { Measurements and } \\
\text { Controls Building } \\
\text { Fire protection } \\
\text { upgrade, } 4500 \mathrm{~N} \\
\text { SNS }\end{array}$ & $\begin{array}{l}\text { Congressional } \\
\text { appropriation language }\end{array}$ \\
\hline
\end{tabular}




\section{C.7.3.1.1 Operating Expense}

Operating expense represents "a broad category of funds which normally includes costs of items that do not meet the criteria for monetary amount and service life associated with capitalization (cost equal to or greater than $\$ 25 \mathrm{~K}$ and a service life of 2 years or more)" (DOE M 135.1-1, Budget Execution Manual). The primary sources of operating-expense funds relating to infrastructure and facilities are the following.

\section{Program}

Program funds are appropriated by Congress for specific program activities. These can be facilities operations funds if they directly support the specified program and are consistent with Congressional language. Also, HQ program guidance will limit and specify what can be done with these funds. Normally, general-purpose capital improvements will not be part of the program operating funds. An exception is the Landlord program, in which GPPs and GPE come out of the operating budget of the program assigned as Landlord. Non-Landlord-program operating funds can also be converted to GPP or GPE, but they must support the program that originates the funds. Federal statute (31 USC 1514, 31 USC 1301) prohibits use of government funds for anything other than the specified use.

\section{Overhead}

Overhead funds are defined as "those allocable costs incurred for the general management, administration, and operation of the contractor, or other costs that benefit the entire enterprise which cannot be directly associated with any specific work efforts. These costs are collected in pools and allocated to all or most of the contractor programs based on a predetermined, DOE-approved methodology" (FY99 Field Budget Call, p. III-12.1).

Generally, maintenance, repair, alterations, and small general-purpose projects not meeting the capitalization criterion may be funded from this account. Alterations are interior rearrangements to better configure a space for a specified use.

A property record unit catalog is used to assist in determining capitalization of various assets (length of fence, water piping, square feet of pavement, etc.). Work that is below the capitalization threshold can be done on operating expense funding. Work that exceeds it must be done with capital funds. The catalog in current use is based on a $\$ 5 \mathrm{~K}$ capitalization criterion. Since the criterion has been raised to $\$ 25 \mathrm{~K}$, the catalog should be revised. This would allow more latitude in completing work on expense funds and perhaps lead to a revision of labor assignments. The catalog revision can be done by the M\&O with approval from the Operations Office. No HQ involvement is required.

\section{"No-Color" Funds}

Due to special program requirements and by specific Congressional authorization, there are some programs (e.g., Environmental Management) that do not distinguish between expense and capital funds. The capitalization criteria still apply, as well as all the limitations of specific categories such as GPP.

Use of "no-color" funds allows either expense-funded projects or capital projects to be funded from the same source. Since GPP and GPE funding have been merged with the program operating account by Congress, program funds are in a limited sense already "no-color." It is possible to convert Landlord program operating funds to GPP or GPE funds for specific capital activities. In addition, it is also possible to convert non-Landlord program funds to program-specific GPP or capital equipment. This 
authority has been maintained at HQ level. Use of Landlord program funds for expense projects may also be a possibility and is discussed in a later section.

\section{C.7.3.1.2 Plant and Capital Equipment}

This is "a broad funding category which includes items of plant and equipment, including both real and personal property, that are owned by DOE and are recorded in the complete plant accounts and meet the monetary and service life criteria for capitalization regardless of the appropriation or fund charged" (DOE M 135.1-1, Budget Execution Manual). Descriptions of specific types of plant and capital equipment funds follow.

\section{Capital Equipment}

Capital equipment is equipment that meets the capitalization criteria: that is, life of greater than 2 years or cost of at least $\$ 25 \mathrm{~K}$. These items can be Landlord general-purpose capital equipment (GPE) or program capital equipment.

Generally, capital equipment funds must be used for capital equipment over $\$ 25 \mathrm{~K}$. However, DOE policy allows research equipment and facilities that are prototypical in nature and are designed to demonstrate feasibility of a process to be funded from operating-expense funds (ORO General Budget Assumptions, FY99). An additional portion of the GPE funds (up to 6\%) may be used for Laboratory Director's Research and Development (LDRD) capital equipment items.

GPE is equipment that supports more than one program at ORNL. If a piece of equipment serves only one program, it should be funded by the program supported. If a project involving capital equipment has more than $20 \%$ construction associated with it, construction funds should be used (DOE FY99 Field Budget Call).

\section{General Plant Projects}

GPPs "are minor new construction projects of a general nature, the total estimated cost of which does not exceed the Congressional authorization of $\$ 2 \mathrm{M}$ per project. General plant projects are necessary to adapt facilities to new or improved production techniques, to effect economies of operations, or to reduce or eliminate health, fire, and security problems" (DOE M 135.1-1, Budget Execution Manual, p. I-7).

GPP projects are not intended to be used in incremental segments to construct larger facilities. Each project should be a stand-alone entity and result in a useable facility or improvement [DOE Accounting Handbook, Sect. 2e(7)]. Each project must remain within the \$2M limit mandated by Congress.

Budget guidance indicates that a Landlord GPP must support more that one program at ORNL. If it supports a single program facility, then the GPP should be funded by the supporting program. Funding for GPP projects cannot be shared ("split-funded") by more than one program. [DOE FY99 Field Budget Call, Sect. 11.d(1)(b)].

For both GPP and GPE funds, the capital designation is applied at HQ, and, by request from Congress, the funds are tracked and reported as capital. It is possible in principle to convert additional Landlord program (e.g., Basic Energy Sciences) funds to GPP or GPE. Although this currently would take HQ involvement and approval, it would be desirable to have the authority to specify the amount of GPP/GPE at the field level, more in line with the original Congressional intent. 
DOE-ORO policy allows addition to a GPP-constructed facility or improvement after a full budget cycle passes between the completion of the old project and the start of the new. In addition, FY 1999 budget guidance indicates that funding of discrete work packages in a given year of a multiyear GPP project is allowed. Previously, the only division allowed was between design and construction. This flexibility could allow better costing performance as well as more efficient use of funds because smaller portions of funds would be designated for a specific purpose in a given fiscal year.

\section{Line-Item Construction}

Line-item construction projects are greater than $\$ 2 \mathrm{M}$ and specifically authorized in the Congressional budget documentation. OMB has provided guidance that beginning in FY 1999, line items are to be fully funded up front. This could allow more efficient project funding profiles since the yearly funding would be allocated at the site. However, this concept is meeting with some resistance from some Congressional subcommittees and may not survive.

\section{Accelerator Improvement Projects (AIPs)}

AIPs were previously a line item composed of several discrete subprojects, authorized separately for accelerator and reactor improvements. The change in Landlord policy in FY 1996 shifted this responsibility to the Landlord program operating account. The funds are provided similarly to GPP and GPE with a capital designation, must be used for stand-alone projects, and cannot exceed $\$ 2 \mathrm{M}$.

\section{C.7.3.2 Conclusions}

In general, federal statute prohibits use of government funds for anything other than the intended use. However, except for line items, the intended use is sometimes rather general and determined by HQ within broad Congressional constraints. The Congressional action to merge GPP and GPE with the operating accounts has given considerable flexibility to capital funding that has not yet been fully implemented. It is possible, in principle, to have a considerably larger portion of capital funds, both general purpose and program specific, for infrastructure and facilities upgrades. The trade-off is that these funds now come out of the program operating accounts and compete directly with program research funding.

Aside from the potential increase in capital funding, there are possible flexibilities that could offer enhanced efficiencies in budget execution. These include increased flexibility in the phase funding of GPP projects, the possibility of converting program funds to GPP or GPE, and the increased capitalization level.

\section{C.7.3.3 Recommendations}

\section{Immediate}

1. Consider phase funding of GPP work packages at levels smaller than design and construction to optimize fund usage and costing performance.

2. Update the property record unit catalog to reflect $\$ 25 \mathrm{~K}$ capitalization criterion. 


\section{Longer Term}

3. Work with DOE to gain more flexibility in shaping the GPP/GPE mix of funding at the site level.

4. Negotiate more flexible labor work assignments to more effectively take advantage of the increased capitalization criterion.

\section{C.7.4 Alternate Funding Methods}

\section{C.7.4.1 Results}

Since funding for infrastructure and facilities upgrades at ORNL is limited and there are numerous currently unfunded requirements, it is desirable not only to use available funds in the most flexible and efficient way possible but also to identify additional sources of funding that could be used to offset a portion of these needs (see Table C.3). In the absence of the availability of "no-color" funding, new sources of funds will be operating expense or capital funds that will carry with them the standard limitations that go with the particular category of funds. In addition to these budgeting and accounting limitations, other restrictions relating to areas such as legal, real property, and financial practices can exist. Several potential alternate funding methods were suggested by the committee and are described in the following paragraphs. The limitations are discussed, with an attempt to identify which sources could be viable alternatives for future funding of ORNL infrastructure requirements. Not all are viable for the various reasons listed.

\section{Space Chargeback}

This strategy charges the tenant organization a fee based on square feet of occupied space (or other space measure) to be managed as an overhead distribution. This concept has been in place for some time at other DOE laboratories and is currently in the process of being defined for ORNL implementation.

\section{Program GPP}

A program GPP supports one specific program. Funds are provided by a program other than the Landlord, and all the GPP restrictions apply.

At ORNL, there have been few requests for programmatic GPP projects. This is partially because the guidance has been difficult to interpret and implement and partially because most facilities would qualify for general-purpose funds because they support multiple programs. Since the guidance has been simplified (i.e., if the project supports a single program, it is programmatic) it is now easier to implement.

Examples of programmatic GPPs would be facilities upgrades to biology laboratories, physics program facilities, or other facilities that support or house occupants from a single program. Although it will necessitate asking program sponsors for programmatic GPP funds, it will allow more to be done with general-purpose Landlord funding, which has been seriously cut in the past 2 years.

GPP funds can be generated, with HQ concurrence, from programmatic funds other than the Landlord program for support of program facilities upgrades. 
Table C.3. Alternate funding methods

\begin{tabular}{|c|c|c|c|}
\hline Category & Description & Limitations & Reference \\
\hline $\begin{array}{l}\text { Space } \\
\text { chargeback }\end{array}$ & $\begin{array}{l}\text { Charge tenant organization a fee based on square } \\
\text { feet of occupied space (or other space measure) }\end{array}$ & $\begin{array}{l}\text { Use funds for general-purpose O\&M } \\
\text { Cannot selectively benefit single } \\
\text { program }\end{array}$ & $\begin{array}{l}\text { Cost Accounting } \\
\text { Standards CAS } 402\end{array}$ \\
\hline Program GPP & $\begin{array}{l}\text { Infrastructure GPP funds provided by program } \\
\text { other than Landlord }\end{array}$ & $\begin{array}{l}\text { Same as Landlord GPP, except funds } \\
\text { must be used for facility that benefits } \\
\text { single program }\end{array}$ & $\begin{array}{l}\text { Congressional } \\
\text { appropriation language } \\
\text { FY99 HQ Field Budget } \\
\text { Calll } \\
\text { DOE Acct Handbook }\end{array}$ \\
\hline Program taxes & $\begin{array}{l}\text { Tax ORNL programs across Laboratory for } \\
\text { infrastructure upgrades }\end{array}$ & $\begin{array}{l}\text { Tax cannot be used for general-purpose } \\
\text { upgrades since it would circumvent } \\
\text { Congressional authority } \\
\text { It could possibly be used for specific } \\
\text { program operating projects, taxing } \\
\text { programs that are benefitted }\end{array}$ & $\begin{array}{l}\text { CAS } 402 \\
\text { OR interpretation }\end{array}$ \\
\hline $\begin{array}{l}\text { Landlord } \\
\text { operating } \\
\text { expense }\end{array}$ & $\begin{array}{l}\text { Use of allocated Landlord program funds for } \\
\text { operating-expense activities }\end{array}$ & Must be general purpose & $\begin{array}{l}\text { Congressional } \\
\text { appropriation language } \\
\text { DOE HQ Policy } \\
\text { DOE OR Policy } \\
\end{array}$ \\
\hline $\begin{array}{l}\text { External } \\
\text { private } \\
\text { funding }\end{array}$ & $\begin{array}{l}\text { Funding of facilities or infrastructure by private } \\
\text { entity }\end{array}$ & $\begin{array}{l}\text { DOE retains title to facility unless } \\
\text { property transferred to facility funder } \\
\text { Cannot lease facility back } \\
\text { Excess property transfer and leasing } \\
\text { rules must be followed }\end{array}$ & $\begin{array}{l}\text { Hall Amendment } \\
\text { (42 USC 7256) } \\
\text { Atomic Energy Act, } \\
\text { Sect. } 161 \mathrm{~g}\end{array}$ \\
\hline $\begin{array}{l}\text { M\&O } \\
\text { corporate } \\
\text { funding }\end{array}$ & $\begin{array}{l}\text { Funds provided by ORNL M\&O contractor to } \\
\text { upgrade government facilities or build new } \\
\text { facilities }\end{array}$ & $\begin{array}{l}\text { DOE retains title to facility unless } \\
\text { property transferred to facility funder } \\
\text { Excess property transfer and leasing } \\
\text { rules must be followed }\end{array}$ & $\begin{array}{l}\text { Hall Amendment } \\
\text { (42 USC 7256) } \\
\text { Atomic Energy Act, } \\
\text { Sect. } 161 \mathrm{~g} \\
\end{array}$ \\
\hline $\begin{array}{l}\text { Energy } \\
\text { performance } \\
\text { contracting }\end{array}$ & $\begin{array}{l}\text { External funding of upgrade or facility with } \\
\text { negotiated return on investment financed by energy } \\
\text { savings }\end{array}$ & $\begin{array}{l}\text { Support-activities funding from savings } \\
\text { is currently an issue }\end{array}$ & $\begin{array}{l}\begin{array}{l}\text { Congressional } \\
\text { appropriation language } \\
\text { P.L. } 102-486 \\
\text { HQ DOE policy }\end{array} \\
\end{array}$ \\
\hline $\begin{array}{l}\text { Use portion of } \\
\text { WFO } \\
\text { holdback } \\
\text { funds for } \\
\text { infrastructure } \\
\text { improvements, } \\
\text { repair, or } \\
\text { maintenance }\end{array}$ & $\begin{array}{l}\text { Keeping a portion of the WFO departmental added } \\
\text { factor (DAF) to use for infrastructure operations } \\
\text { and maintenance activities }\end{array}$ & $\begin{array}{l}\text { Can use DAF or local added factor } \\
\text { funds only for full cost recovery } \\
\text { Facilities/maintenance depreciation } \\
\text { factored in }\end{array}$ & $\begin{array}{l}\text { Economy Act ( } 31 \text { USC } \\
1535 \text { and } 1536) \\
31 \text { USC } 9701 \\
\text { OMB A-25 }\end{array}$ \\
\hline $\begin{array}{l}\text { Use proceeds } \\
\text { from property } \\
\text { or scrap sales } \\
\text { for } \\
\text { infrastructure } \\
\text { improvements, } \\
\text { repair, or } \\
\text { maintenance }\end{array}$ & $\begin{array}{l}\text { Keeping a portion of the proceeds from scrap or } \\
\text { excess property sales for infrastructure upgrades or } \\
\text { O\&M }\end{array}$ & $\begin{array}{l}\text { Can keep proceeds in loss operation } \\
\text { Full cost-recovery statutes apply- } \\
\text { excess goes back to Treasury } \\
\text { Can possibly barter property for } \\
\text { services }\end{array}$ & $\begin{array}{l}\text { OMB A-125 } \\
42 \text { USC } 7256 \\
\text { Congressional } \\
\text { appropriation language }\end{array}$ \\
\hline
\end{tabular}




\section{Program Taxes}

Program taxes would tax ORNL programs across the Laboratory for infrastructure upgrades. Although it may be possible from an accounting viewpoint to use a program tax to fund some general-purpose infrastructure activities, the use of a tax on several or many programs could not be used to benefit a specific program activity since it would be interpreted by DOE, based on 31 USC 1302 (a), as augmenting an appropriation. If a tax were used, it would have to show a causal-beneficial relationship (i.e., some relationship must exist between the assessed programs and the benefitting programs).

In addition, since the cost-accounting standards prohibit the distribution of the same or similar costs from different sources, the tax would have to support a materially different set of activities than is currently being performed on overhead (or through another source). If these conditions can be met, a program tax may be a viable alternative. One possibility may be with In-House Energy Management (IHEM) Program noncapital activities. Congress stopped direct funding of IHEM in FY 1996 and left the matter to DOE sites, and IHEM activities are not currently being done out of overhead. This may include supporting work relating to energy-savings contracts. It appears that, even though a program tax may be a viable alternative within accounting and legislative limitations, proposals to date have been generally viewed by both DOE-ORO and DOE-HQ as efforts to circumvent Congressional authority.

\section{Landlord Direct-Operating Funding}

Landlord program funds could be used to directly fund general-purpose infrastructure operating activities. These could include ES\&H activities, orphan facilities operating activities, or other operating activities that are not currently being funded. This would be analogous to the budget and reporting code KG operating program before the Landlord program change.

The original Congressional intent when putting the GPP and GPE funding under program operating accounts was to enable flexibility in funding Landlord capital projects and equipment. However, the authority for converting program operating funds into GPP or GPE has been kept at HQ, with no specific mention of Landlord operating expense funding.

Use of Landlord funds for operating expense projects is currently being supported by the Site Office with the Oak Ridge Institute for Science and Education (ORISE). The ORISE Landlord the Office of Health and Environmental Research (OHER)] does not appear to have any objections, and it makes efficient use of the potential flexibility of the available Landlord funding. The trade-off is that these requirements will compete with GPP and GPE for a limited amount of funding.

\section{External Private Funding}

This designation applies to the funding of a laboratory or support facility by an external private funding source or sources. This can be done in two ways. The first method is allowed by the Hall Amendment to the Department of Energy Act (42 USC 7256, Sect. 646) and involves leasing a piece of land to an organization and letting it build on the property. (DOE retains the title to the facility.) This is problematic for the builder in that the facility cannot be leased back to the government because the government already owns it. In the second method, land determined to be excess by the government is disposed of through normal property-disposal procedures. A private entity then builds on the land and enters into an agreement with the government on use of the facility. This is complicated by the fact that government leasing of a facility on land that was stated to be excess to the government is questionable to authorities in DOE-HQ Legal. 


\section{Performance Contracting}

Performance contracting is external funding of an upgrade or facility with the negotiated return on investment for the funding contractor paid out of energy savings. A performance contract for an energysavings performance contractor (ESPC) is currently being developed for all three DOE-ORO sites. The contract will probably have separate awards for each site, with a task order to be negotiated for each project done under the contract. Funding issues with this approach relate to providing support to the ESPC doing on-site work (building access, operations coordination, building tie-ins, etc.). Currently, there are legal and financial issues with funding this support through a portion of the energy savings.

\section{Work-for-Others (WFO) Added Factor}

This process involves keeping a portion of the WFO departmental added factor (DAF) or depreciation factor to use for infrastructure operations and maintenance activities.

The DAF is added for full cost recovery mandated by the Economy Act (31 USC 1535 and 1536) and 31 USC 9701. Administrative upper limits are placed on DAF recovery by the Energy and Water Appropriations Act. All proceeds above full cost recovery of out-of-pocket contractor expenses are returned to a departmental account to offset DOE future budgets. The depreciation rate considers depreciation of government facilities and equipment and applies only to commercial customers. The current (FY 1997) rate for ORNL is $8 \%$. The DAF is $12.4 \%$ for commercial work and $4.3 \%$ for other government agencies. A local added factor (LAF) could be added to offset costs not recovered with the DAF. There is currently no LAF since no additional costs have been identified.

Appropriation law does not allow use of excess funds in WFO transactions for the purpose of directly improving or maintaining facilities. However, if maintenance is normally directly charged to programs, a direct charge could be assessed from WFO for maintenance related to facilities used in WFO activities.

\section{Excess Property Proceeds}

This process involves keeping a portion of the proceeds from scrap or excess property sales for infrastructure upgrades or operations and maintenance.

For real property, it is possible to keep proceeds from sales to defray operating costs, but the net excess must be returned to the Treasury. This is done at DOE-ORO in land and timber sales. A further possibility currently being investigated by DOE-ORO in conjunction with the reindustrialization initiatives is bartering with excess equipment. Although it is not possible to sell government property and keep funds in excess of the costs of doing business, it is possible (due to lack of legislation to the contrary) to trade property for services (e.g., cleanup services). The possibility of trading excess property or scrap for other capital has not been tested. Although this may be a viable way of addressing certain issues for reindustriaization, it does not appear to be a satisfactory way to solve long-term maintenance and capital-funding issues.

\section{C.7.4.2 Conclusions}

There are a number of potentially viable sources of funds for infrastructure and facilities activities at ORNL beyond the traditional or currently used sources. These include program tax; space charge; program GPP; external funding; performance contracting; and possibly, Landlord operating-expense funding. Due to restrictions of federal law, a number of sources such as WFO tax and property sales are 
not promising sources for generating excess funds to be used on facilities upgrades or maintenance. Only the program GPP, performance contracting, and external funding represent net increases in capital funding for ORNL. The others represent exercise of flexibilities in the system to reallocate existing funds for infrastructure and facilities tasks.

\section{C.7.4.3 Recommendations}

\section{Immediate}

1. Improve process for identifying and budgeting for programmatic GPPs.

2. Consider external private funding for ORNL facilities that can both leverage ORNL facilities development and attract private-sector participation-for example, the Biology Complex.

3. Use performance contracting as much as possible to ease the burden on traditional capital-funding sources.

\section{Longer Term}

4. Work with DOE to increase the total GPP/GPE allocation to ORNL. Define process for identifying recommended split of total pool between GPP/GPE/operating-expense funding.

5. Look at the possibility of a program tax for specific infrastructure or facilities-related activities not currently funded. Examples are the former IHEM Program and support to ESPC activities.

\section{C.7.5 Unfavorable Funding Profiles}

\section{C.7.5.1 Results}

Funding that arrives late in the fiscal year or funds that are phased over 2 or more fiscal years in a nonoptimal manner cause difficulty in efficient management of projects.

A primary impact of late funding is the difficulty of costing funds by the end of the fiscal year. A recent waste management report suggests that for a GPP construction project, a 1-month schedule slip could increase year-end uncosted balance by up to $10 \%$. Another complication is the possibility of escalation or added costs due to delays in awarding contracts. As a result, late funding can shift a seasonal project into another fiscal year, adding cost to the project and delaying needed improvements. The difficulty is compounded by not having projects ready to award when the funding arrives. Although not much can be done about late Congressional budget actions, mitigating factors may include speeding processing time for getting funds into the financial plan and having projects ready to go when funds become available.

The budget process involves Congressional appropriation, OMB allocation, and DOE distribution of funds to field sites. The HQ distribution to the field takes $\sim 8$ working days. The Oak Ridge distribution takes about 7 working days. The driving factor is that the EM budget must be approved by EM program managers prior to inclusion in the financial plan, which generally takes about 1 week. Since the financial plan is a large document, it is DOE-Oak Ridge policy to do only one per month. The Environmental Restoration portion could be distributed in a day if it were not constrained by the other program budgets. In special circumstances, DOE-Oak Ridge can make distribution in an interim financial plan in a shorter time frame. Oak Ridge has recently initiated electronic transfer of monthly financial plan changes, 
although the current plan is to use an E-mail transfer of the approved final financial plan once a month. In principle, it would be possible to transfer the ORNL portion of the financial plan (minus EM) approximately a week earlier if DOE-Oak Ridge agreed to do multiple financial plan distributions per month.

A straightforward solution to minimizing impacts of late funding is to have projects ready to go when funding arrives. Currently, there is often a significant amount of time between funding arrival and project start due to preaward activities that have not been completed. For projects going into construction, this could include the following activities before funding arrives: completion of the CFC process; construction readiness reviews; and bid package preparation, review, and approval. This up-front activity could potentially save 2 weeks or more in the overall process. If the job were put out for bid, another 2 weeks could be saved, although an award could not be made until funds were in hand.

A possible local barrier would be related to risk-committing expense funds to a procurement action, with the risk that it may not be funded. However, this risk is low in the case of GPP funds since funding of at least a minimal level can be verified ahead of time. (It is not a Congressional authorization.) In the case of line items, the funding is known ahead of time but is slightly more vulnerable since Congress could pull back some or all of the funds before the project starts.

The impacts of unfavorable funding profiles in phased projects could be mitigated with the new OMB policy on up-front funding for line-item projects. Beginning in FY 1998, projects are to be fully funded in the first year. This will enable organizations using the funds to budget and allocate funds efficiently according to the needs of the project, rather than basing funding on an arbitrary funding profile dictated by HQ and Congressional priorities. In some circumstances, OMB will recommend phase funding, with separate project pieces (stand-alone) funded in subsequent years. This policy could alleviate the problem of nonoptimal fiscal-year funding but would not solve the problem of late funding. It would also potentially cause problems in costing performance since larger uncosted balances would be a result. It is uncertain at this point whether Congress will go along with this policy.

\section{C.7.5.2 Conclusions}

Late funding effects can be mitigated somewhat by ensuring that projects are ready to proceed when funding arrives. Improvements of processes for design and construction need to be implemented. A small amount of time (up to a week) could be saved by DOE-ORO by getting funds into the financial plans in a more timely manner.

\section{C.7.5.3 Recommendations}

The following actions are recommended.

1. Revise design and construction preaward processes to enable work to be ready to go when funding becomes available.

2. Request that DOE-ORO send financial plan updates to ORNL separately from other sites to avoid delays due to non-ORNL programs. 


\section{C.7.6 Program/Infrastructure Decisions}

\section{C.7.6.1 Results}

Decisions on infrastructure and facilities funding occur at both field and DOE-HQ levels. The field is responsible for planning for and recommending levels of funding in program, GPP, GPE, and line items and for budgeting levels of facilities support in overhead. DOE-HQ decides ultimate levels of funding for program, GPP, and GPE (both program and general purpose) and makes recommendations to Congress on line-item projects.

\section{Line Items}

The line-item funding decision for general-purpose facilities is made at DOE-HQ based on justifications from DOE sites and cost to the government. The projects need to show support for the DOE mission and well-documented justification in order to be sellable to OMB and Congress. Barriers to obtaining funding include not enough funds in the DOE budget and project proposals that do not meet the needs of the program. In addition, past performance and perceptions of performance influence HQ decisions on funding of ORNL projects. Although the amount of funds available for distribution to DOE laboratories for infrastructure and facilities in line-item projects is controlled by Congress, the barriers related to project selection and justification, as well as performance, should not be insurmountable.

HQ complaints on projects submitted from the field have included poor justifications (no supporting facility condition data available, perceived lack of strategic planning), questionable need (requesting office space when available space is not being managed, trying to get to zero risk level), and poor project sizing (TEC higher than can be supported by budget). At the site level, barriers to making quality decisions on line-item funding requests (general purpose and programmatic) have included politics, lack of understanding or communication of requirements, doing things the traditional way, and the pressure to request "full-requirement" projects as a substitute for prioritization of needs.

\section{GPP/GPE/AIP}

With these funds, the decisions on specific projects are made at the field level based on established priorities. The funding-level decisions are made at HQ with input from the field and compete directly with programs for funds. The chief barrier is the difficult trade between funding infrastructure and facilities needs at the site and funding program R\&D activities. Although ORNL routinely submits fiscal-year Landlord budgets that request adequate funding, the follow-up negotiations for actual funding levels have resulted in considerably less funding. The barrier appears to be HQ-DOE and M\&O reluctance to commit increased levels of program funds for Landlord activities to support the Laboratory mission.

Since the Landlord program is currently funded through a program activity (KC), a natural tendency exists for the ORNL program to want to be involved in setting levels of Landlord funding. Although there should be some level of program coordination in the budgeting phase, the ORNL organization responsible for Landlord program activities should take a strong lead in establishing, requesting, and negotiating budget levels that responsibly reflect site and facilities needs. 


\section{Overhead}

Decisions on ORNL overhead consider a range of competing interests including infrastructure (maintenance, repair, alterations, small projects, etc.), ES\&H support, laboratory operations, and staff functions. Unfortunately, the inadequate levels assigned to facilities care in the past have resulted in significant deterioration of facilities (e.g., problems with roofing). Barriers to including more infrastructure and facilities funding in the overhead budget include competition from other areas of the overhead budget and pressures to keep the overhead rate down. It may also include the perception that facilities issues are less important than other more visible issues.

Possible solutions to removing or lessening these barriers are lowering the competing requirements through efficiency or outsourcing, accepting higher levels of risk, making a conscious decision to increase facilities and infrastructure funding in particular areas, or finding direct funding for specific problems.

\section{Planning}

Facilities and infrastructure need to be acknowledged as critical support for the strategic Laboratory mission. A significant factor in low levels of infrastructure funding is related to lack of a thorough process for integrating infrastructure and facilities planning with programmatic strategic planning, budgeting, and execution. Although there is documentation of facilities and infrastructure requirements in several ORNL planning and budgeting documents, the link between the identified facilities needs and the programmatic mission planning needs to be strengthened. Impacts of new program facilities or upgrades on infrastructure, as well as the impacts of infrastructure and facilities upgrades on research activities, need to be considered more thoroughly.

\section{C.7.6.2 Conclusions}

Decisions on facilities/infrastructure funding are influenced by competition from programmatic and other funding requirements, visibility and perceived importance of infrastructure and facilities needs, and perceived performance.

There is no strong integrated mission/facilities focus on planning and execution.

\section{C.7.6.3 Recommendations}

The following actions are recommended:

- give more attention to line-item justifications based on actual condition, impact on the ORNL mission, and life-cycle costs in order to better support DOE budget requests to Congress; and

- fully integrate facilities and infrastructure planning with strategic program planning, budgeting, and execution. 


\section{C.8 PERFORMANCE MEASURES (E. H. Krieg and J. W. Mathys)}

\section{C.8.1 Background}

Performance indicators have been widely used for many years to monitor an organization's financial performance but have only recently been recognized as an important element of all quality programs. Managers directing the efforts of an organization or group require information in order to operate efficiently and effectively. Performance measures are the primary means by which management can assess the delivery of products and services to the customer and form the basis for making intelligent decisions. They quantitatively tell us something important about the products and services we produce as well as the processes that produce them. If properly selected and utilized, they are a key tool in helping us understand, manage, and improve what our organizations do.

The LMES Central Engineering Services Organization has utilized performance measurement to monitor service delivery for many years. These metrics measure many facets of the engineering and project management process, and many are widely used by managers to gauge and monitor performance. It is our hope to improve on this measurement process by recommending a set of performance measures that monitor those critical few parameters that ultimately will indicate the success of the ORNL ECMD.

The most effective set of performance measures relates directly to customer satisfaction. By concentrating on the customer as the central focus for all activities, the most important measures of performance become evident. Cost-effectiveness, adherence to schedule, safety, and overall quality of the product are always the key components which, if achieved, lead to a satisfied customer. By concentrating on these key components, several of the pitfalls of other performance measurement systems can be avoided.

Most of the problems and failures associated with performance measurement programs result when a complex system is broken down into simple processes, each of which is measured. This frequently causes each individual or group to focus only on those areas in which they are being measured. Because all activities become more visible, management and individuals alike are more prone to "crisis catering" and micromanagement, which allows inordinate amounts of resources to be expended on activities or problems which add little to the final product. By maintaining broad goals and utilizing a team-centered approach, customer focus is more easily attained as each individual is aware of how his or her efforts are interrelated with those of other team members and how the team's success equates to customer satisfaction.

\section{C.8.2 Process}

The Performance Indicators/Performance Factors Reengineering Subteam was chartered to develop performance indicators that accurately measure the overall performance of the ORNL ECMD and that can be compared with those of recognized leaders in the project development and management field. The team researched a number of different organizations in government, quasi-government, and commercial fields in an attempt to identify those with the best performance and to determine what processes they are using. The study focused on end-product results, with an emphasis on producing standards that can be compared with the performance measures chosen. 
As a result of this research, three general areas were chosen for which performance measures will be developed for comparison purposes:

- DOE multiprogram laboratories,

- R. S. Means cost-estimating data, and

- the Construction Industry Institute.

\section{C.8.3 Results}

\section{C.8.3.1 DOE Multiprogram Laboratories}

The ED\&C Benchmarking Subteam held extensive teleconference interviews with Engineering and Facility Management managers and staff members from each of our closest competitors: Lawrence Berkeley National Laboratory (LBNL), Brookhaven National Laboratory (BNL), Argonne National Laboratory (ANL), and Pacific Northwest National Laboratory (PNNL). Part of the interviews centered on what types of performance measures each of these laboratories was using to monitor its engineering and construction processes and what, if any, results had been noted (for comparison purposes). The answer from each competitor was the same: none currently monitors its processes in any formal way other than what is required by DOE in the Life-Cycle Asset Management (LCAM) Order. These measures provide a very generic glimpse of how their processes operate; however, they are the only basis for the Performance Measurement Subteam to provide a direct comparison of our performance with that of our competitors. These performance measures are as follows.

\section{Oak Ridge National Laboratory}

1. Design and construction costs reflect efficient project management.

Measure: Design costs plus construction costs divided by total estimated cost (TEC). Goal to be achieved is $60 \%$ or better.

2. Approved technical, cost, and schedule baselines are met without significant changes.

Measure: Total of the TECs for GPPs/line-item projects completed during the fiscal year divided by the total authorized TECs for those projects. Goal to be achieved is $100 \%$.

Measure: Number of months for GPP/line-item project completion divided by the baseline schedule in months. Goal to be achieved is $100 \%$.

3. Projects are costed in a timely fashion.

Measure: Fiscal year project budget costed divided by fiscal year budget authority (line items and GPPs assessed separately). Goal to be achieved is $50 \%$.

4. Facility turnover and projected closeout activities are completed in a timely fashion.

Measure: Cumulative number of months after project completion divided by four (4) times the number of projects. 


\section{Lawrence Berkeley National Laboratory}

LBNL currently generates only those performance measures required by LCAM. These include the following:

1. Project schedule-Construction projects greater than $\$ 500 \mathrm{~K}$ and less than $\$ 2000 \mathrm{~K}$ meet baselines.

2. Total estimated cost-Line-item projects (including any project $\$ 2000 \mathrm{~K}$ and over regardless of types of funds) meet baselines.

3. Project schedule-Line-item projects meet baselines.

4. Work performed-Line-item projects meet baselines.

\section{Brookhaven National Laboratory}

BNL uses several performance measures that are a part of its contract:

1. on-time performance,

2. completion of GPP on time,

3. completion of line-item milestones, and

4. effectiveness of obligation of money against planned costs.

\section{Argonne National Laboratory}

ANL uses project and facility management-related LCAM performance measures:

1. Approved projects are completed on time and within budget and meet baseline scope requirements.

2. Project schedule compliance-TEC for all projects that are evaluated, divided by the sum of [actual duration in months to complete a project (weighted by TEC)] and then divided by the baseline duration to complete the project.

3. Cost and scope completion within approved baseline-Sum of [percent completed approved scope for each project at project completion (weighted by TEC)] divided by the sum of the TECs scheduled to be completed.

Because of a lack of substantive data from these organizations, additional investigations were undertaken in an effort to determine those government entities whose performance is considered to be "best in class." Many government agencies are currently publishing what they advertise to be benchmarking and performance measurement information on the World Wide Web. Among those organizations contacted regarding the possibility of being benchmarking partners by this method were the following. 
U.S. Army Armament Research, Development and Engineering Center (ARDEC) at Picatinny Arsenal, New Jersey-This organization has won numerous quality improvement awards sponsored by the state of New Jersey and has advertised a willingness to benchmark and share information with other organizations. Both E-mail and verbal contact was made with the organization's Performance Improvement Team to determine if we could be of mutual support. A copy of the ARDEC Engineering Support Team's Process Improvement Report was E-mailed for our review. It was apparent that the processes they were most concerned with were those in the armament development and production area, and it was impossible to find common points for comparison. Their report did include a list of companies that they had contacted for benchmarking purposes. Our subteam evaluated this list and subsequently contacted these other companies regarding our own benchmarking project. At this date, all companies that were contacted have failed to respond.

Army Corps of Engineers-This contact held a great deal of promise initially. The Corps research center in Indiana was contacted regarding the possibility of sharing some performance measurement data. While the individual contacted was eager to help, the Corps did not measure performance for their ED\&C process. Like ORNL, they were embarking on a reengineering effort and were hoping to develop benchmarking measures for their own processes. This contact will remain open, and we hope to share information in the future.

National Aeronautics and Space Administration-According to available literature, this organization has world-class processes that it is willing to share with other government agencies and industry. Numerous attempts to contact individuals identified as key contact points have been made, but these individuals are either unwilling or unable to help us. The contact will remain open, and we hope to be able to share with them in the future.

National Renewable Energy Laboratory (NREL)-Central Engineering Services had made a benchmarking trip to this organization in 1994, and the subteam contacted NREL again. Some initiatives were planned and in the formative stages when the benchmarking trip was made, and we were interested in the success of these ventures. An inquiry was made, and the response included a great deal of information that may be applicable to our operations. While both ORNL and NREL are DOE research laboratories, the method of management, oversight, and operation of the facilities differs greatly.

Sandia National Laboratory-Sandia had helped DOE develop a technical handbook on how to measure performance; therefore, we were optimistic that Sandia would be able to provide us with extensive information. Unfortunately, Sandia has not yet embarked on any performance improvement initiatives for the ED\&C processes. Again, the contact will remain open, and we hope to be able to use them as a benchmarking partner in the future.

Idaho National Engineering Laboratory (INEL) — Contact was made with members of INEL's engineering staff. Currently, INEL has internal performance measures to monitor ongoing operations but does not use performance measurement to benchmark against other facilities or industry. INEL is currently negotiating with DOE regarding the development of some project management goals and measures. INEL will be an outstanding choice for a benchmarking partner once its measurement program is in place because the facility used a construction manager until the last year. When the system is in place, INEL should be able to provide valuable information comparing project management performance utilizing a construction manager with performance without these services.

A number of other attempts were made, with essentially the same results. Those contacted either did not currently measure ED\&C processes or were in the development phase of their own performance 
measurement programs. Formal performance measurement in the government is new, and apparently most organizations are in the midst of developing programs similar to that which we hope to develop. This should provide a fertile field for benchmarking and comparison purposes in the future, and those individuals involved in the implementation of the performance measurement program should have a considerable collection of facts to choose from for comparison/benchmarking purposes.

\section{C.8.3.2 R. S. Means Cost-Estimating Data}

R.S. Means Company publishes data on expected cost ranges for various project engineering components. These data are published as an expected range and can be useful in determining if a project is on track or if trouble can be expected. Included in the cost guides are data on project components such as the following:

- architectural fees,

- construction management fees,

- project contingency factors,

- miscellaneous engineering fees (by discipline),

- job condition factors,

- favorable/unfavorable economic conditions factors,

- unfavorable hoisting conditions,

- inexperienced contractor management, and

- labor availability.

As stated before, these data are useful in monitoring the progress of a project, whether it be in the conceptual, design, or construction phase. The ranges listed in the Means Cost Guide should be used for reference only, not interpreted as a formal measure of project performance.

R. S. Means and other firms in the cost-estimating business also publish square-foot and unit-cost guides that can be used for conceptual estimates as well as for comparison purposes. These guides utilize historical construction cost data from hundreds of commercial, institutional, and industrial buildings to allow the user to develop preliminary information for his or her own project. Sections also provide historical costs for installed components within buildings so that a true estimate of what a particular project might cost can be developed relatively easily within a short time period. This type of information is also useful in assessing project performance by allowing comparison of current actuals with historical costs. Such a comparison can help gauge whether a project is on track or if trouble can be expected because of cost overruns.

\section{C.8.3.3 The Construction Industry Institute}

The Construction Industry Institute began to develop metrics for the construction industry in 1993 and completed initial data collection in 1996. The Institute defined a set of "critical few" metrics in the areas of cost, schedule, and safety, as well as measures designed to gauge the success of efforts in preproject constructibility, and team building.

The metrics currently available from the Institute are slanted towards heavy industrial projects, but efforts in the future will expand the data base to become more representative of all groups within the construction industry. Composite indices are available as well as indices for individual business sectors. The Institute hopes to present data for the critical few metrics in a form that will allow participants to compare their performance with industry "norms" and to use these data to improve their overall project performance. 
The benchmarking and metrics reports are available from the Institute. Developing a similar set of measures for ORNL will allow us to compare and contrast our project performance with that of firms in the commercial sector and, hopefully, gain insight into the processes and practices that make their projects successful.

\section{Cost Performance Metrics}

Three cost performance metrics developed and tracked by the Construction Industry Institute are as follows:

- Budget factor-A ratio of the actual total cost of the project to the budget. A budget factor of 1 represents perfect performance, a value less than 1 indicates a cost underrun, and a value greater than 1 indicates a cost overrun.

- Cost growth-The ratio of the difference between actual total cost of the project and the budget at the start of detailed design to the budget at the start of detailed design.

- Phase cost factors-Measure project phase cost as a percent of total installed cost.

\section{Schedule Performance Metrics}

Three schedule performance metrics defined by the Institute are as follows:

- Schedule factor-A ratio of the actual total duration of a project to the initial predicted duration at the start of detailed design. A schedule factor of 1 represents perfect predictability. A factor value of less than 1 represents a schedule underrun, while a value greater than 1 indicates a schedule overrun.

- Schedule growth-A ratio of the difference between the actual total duration of the project and the predicted duration at the start of detailed design to the initial predicted duration at the start of detailed design.

- Phase duration factor-Measures project phase duration as a percent of total project duration.

\section{Safety Performance Metrics}

Data for the comparison of these two metrics are available from the Occupational Safety and Health Administration as well as from the Construction Industry institute. Comparison of the incident rates for different types of project helps to identify those projects that typically result in higher incident rates. This comparison will allow project managers and planners to proactively plan on using construction methods that will reduce the exposure of employees to potential incident-producing situations.

Two safety performance metrics tracked by the Institute are as follows:

- recordable incident rate (RIR), and

- lost workday case incident rate (LWCIR). 


\section{Best-Practices Assessment Metrics}

These measures are derived through a method similar to a "lessons learned" analysis. The project assessment occurs after the project has been completed. The project is reviewed to assess the use of bestpractice methodologies to give an indication of the impact that new or modified practices have on project performance or may have on future projects. The Construction Industry Institute collects data for four recommended management practices. These include preproject planning, constructibility, team building, and planning for project safety. Two types of analysis can be used to determine the success or failure of efforts to implement these practices into the project management process. The first type of analysis is simply an assessment of the extent to which the various best practices are utilized in projects. The second type encourages users of the data to analyze their projects to determine how best practices affect project performance as measured by the cost, schedule, and safety metrics. The best practices monitored by the Institute are defined as follows:

- Preproject planning-Making sure that the project is adequately defined and that the end result will yield a satisfied customer.

- Constructability assessments-A formal determination of what the most efficient and effective construction methods are for the defined project.

- Team building-Measures the effectiveness of the project team by examining how the group functioned, how responsibility and accountability were incorporated, and how committed the team was to project success.

- Planning for project safety-Examines project safety statistics to determine if nontraditional construction methods were incorporated into the project to mitigate the hazards presented to project workers.

\section{C.8.3.4 Conclusions}

An effective performance measurement system is an essential ingredient in any process improvement effort. In order to create a system that will be accepted and used by individuals within the organization, managers and subordinates must be committed to participating in the creation of the performance measurement system. The greater the degree of participation in the process of creating the system and the measures, the easier it will be to implement. A participative approach helps generate enthusiasm for the system and promotes an understanding of the need for and the importance of each measure. Measurement systems of any kind will focus attention not only on the processes and activities being measured but also on the individuals involved in those activities. It is important that each measure be directed at a process or activity, not at individuals or employee groups. The process of measurement must be clearly separated from the process of evaluation. The team that produces the results will be the best candidates to develop the measure(s), perform the measurement, and report the results. The goal should always be to design, develop and successfully implement measurement systems that share information in such a way that continuous improvement is supported by all participants and enhanced by the system itself.

A number of measures and reference sources have been identified for benchmarking and comparison purposes. Because of the nature of our situation and the numerous rules and constraints placed upon how we conduct our work, development of a similar set of measures for ECMD will be a difficult task. Unit values, for instance, are easily obtained from a number of sources, but direct comparison of these numbers cannot be made from one region to another or from one industry to another, despite the fact that, 
on the surface, they seem to be the same measure. Factors must also be developed with the measure that will allow for a meaningful comparison. The individuals or groups that develop performance measures for the EDMD must ensure that not only will the results they are generating be calculated in the same manner as those used for comparison but also that these adjustment factors be applied in order for a legitimate comparison to be made.

\section{C.8.3.5 Recommendation}

Over the next few months, groups and individuals within the organization will be identified who will be responsible for the development and maintenance of performance metrics for the ORNL ECMD. This subteam's efforts involved identification of potential performance metrics and benchmarking partners. Those measures that have been identified will serve as an excellent platform from which to launch our own performance measurement program. As this program matures, additional measures should be identified, developed, and implemented that will assist in the development of a world-class organization. 


\section{INTERNAL DISTRIBUTION}

1. B. R. Appleton

2. J. B. Ball

3. J. R. Beene

4. R. A. Bradley

5. F. E. Bertrand

6. E. R. Bowers

7. S. E. Burnette

8. D. F. Craig

9. G. A. Dailey

10. R. M. Davis

11. J. L. Dippo

12. L. B. Dunlap

13-22. J. T. Etheridge

23. M. P. Farrell

24. G. F. Flanagan

25. E. C. Fox

26. C. W. Gehrs

27. R. K. Genung

28. R. G. Gilliland

29. J. L. Hammontree

30-31. J. N. Herndon

32. J. R. Hickey

33. H. R. Hicks

34. S. G. Hildebrand

35. P. B. Hoke

36. R. H. Honea

37. R. C. Juras

38. K. L. Kliewer

39. M. W. Kohring

40. F. C. Kornegay

41-45. E. H. Krieg, Jr.

46. M. A. Kuliasha

47. R. C. Mann

48. R. C. Mason

49. J. W. Mathys

50. D. W. McDonald

51. B. M. McNelly
52-71. L. E. McNeese

72. A. R. Medley

73. G. E. Michaels

74. T. E. Myrick

75. C. E. Oliver

76. D. C. Parzyck

77-79. B. D. Patton

80. J. E. Phillips

81. W. W. Pope

82. M. L. Poutsma

83. C. E. Pugh

84. D. E. Reichle

85. H. L. Rhude

86. J. B. Richard

87. J. B. Roberto

88. A. R. Sadlowe

89. M. J. Saltmarsh

90. A. C. Schaffhauser

91. J. A. Setaro

92. R. B. Shelton

93. A. M Shirley

94. C. S. Sims

95. D. R. Stallions

96. J. G. Stradley

97. J. H. Swanks

98. J. R. Trabalka

99. A. W. Trivelpiece

100. R. J. Verastegui

101. D. A. Waters

102. C. D. West

103. J. C. Whitefield

104. M. C. Willard

105. T. Zacharia

106. Central Library

107. ORNL Laboratory Records-RC

108-109. ORNL Laboratory Records-OSTI

\section{EXTERNAL DISTRIBUTION}

110. G. W. Benedict, U.S. Department of Energy, Oak Ridge Operations, 200 Administrative Road, Oak Ridge, TN 37830

111. Mr. Rudolph Bouie, Argonne National Laboratory, 9700 South Cass Avenue, Argonne, IL 60439 
112. Mr. J. Robert Camper, Lawrence Berkeley National Laboratory, 1 Cyclotron Road, Mail Stop 90k, Berkeley, CA 94720

113. Mr. George S. Criss, University of Tennessee, Facilities Planning, Knoxville, TN 37996

114-123. E. G. Cumesty, ORNL Site Manager, Oak Ridge Operations Office, U.S. Department of Energy, P.O. Box 2001, Oak Ridge, TN 37831-6269

124. Patrick M. Dempsey, P.E., Deputy Division Leader, Lawrence Livermore National Laboratory, Design \& Construction Division, Plant Engineering, P.O. Box 808, L654, Livermore, CA 94551

125. P. D. Dayton, U.S. Department of Energy, Oak Ridge Operations, 200 Administrative Road, Oak Ridge, TN 37830

126. Mr. Mike Glaser, National Renewable Energy Laboratory, 1617 Cole Blvd., Golden, CO 80401-3393

127. David K. Johnson, P.E., Director, Electric Utilities Division, Lawrence Livermore National Laboratory, P.O. Box 808, L604, Livermore, CA 94551

128. M. J. Kass, Oak Ridge Site Office, Oak Ridge Operations Office, U.S. Department of Energy, P.O. Box 2001, Oak Ridge, TN 37831-6269

129. Mr. Mark Kelley, Sverdrup Technology, Inc., Arnold Engineering Development Center, 877 Avenue E, Arnold Air Force Base, TN 37389-5150

130. L. C. Kelly, U.S. Department of Energy, Oak Ridge Operations Office, 200 Administrative Road, Oak Ridge, TN 37830

131. G. C. Manthey, Oak Ridge Site Office, Oak Ridge Operations Office, U.S. Department of Energy, P.O. Box 2001, Oak Ridge, TN 37831-6269

132. Roy F. Neyer, Division Leader, Projects Division, Lawrence Livermore National Laboratory Plant Engineering, P.O. Box 808, L654, Livermore, CA 94551

133. Mr. Marvin E. Olson, Battelle Pacific Northwest Laboratory, P.O. Box -999/MS P7-63, Richland, WA 99352

134. Mr. Leo Ponder, ACS, Arnold Engineering Development Center, 100 Kindel Drive Arnold Air Force Base, TN 37389-1211

135. Mr. Michael Schaeffer, Brookhaven National Laboratory, Plant Engineering, Bldg. 134C, Upton, NY 11973-5000

136. Mr. John A. Shaffer, National Renewable Energy Laboratory, MS 2711, 1617 Cole Blvd., Golden, CO 80401

137. J. G. Yates, ER-82, U.S. Department of Energy, Headquarters, 19901 Germantown Road, Germantown, MD 20874-1290 